Universidad de Lima

Facultad de Derecho

Carrera de Derecho

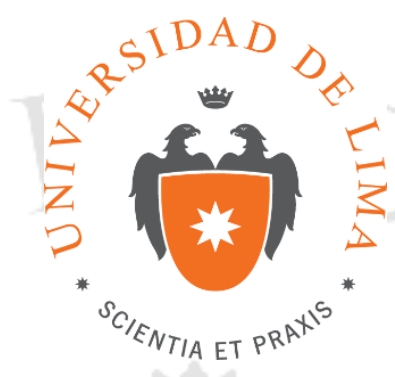

\title{
JUSTICIA RESTAURATIVA: LA EVASIÓN NO VIOLENTA COMO UN NUEVO SUPUESTO DE REMISIÓN
}

Tesis para optar el título profesional de Abogado

\author{
Ian Jorge Medina Salas
}

Código 20062648

\author{
Asesor \\ Jorge Luis Salas Arenas
}

Lima - Perú

Abril del 2018 


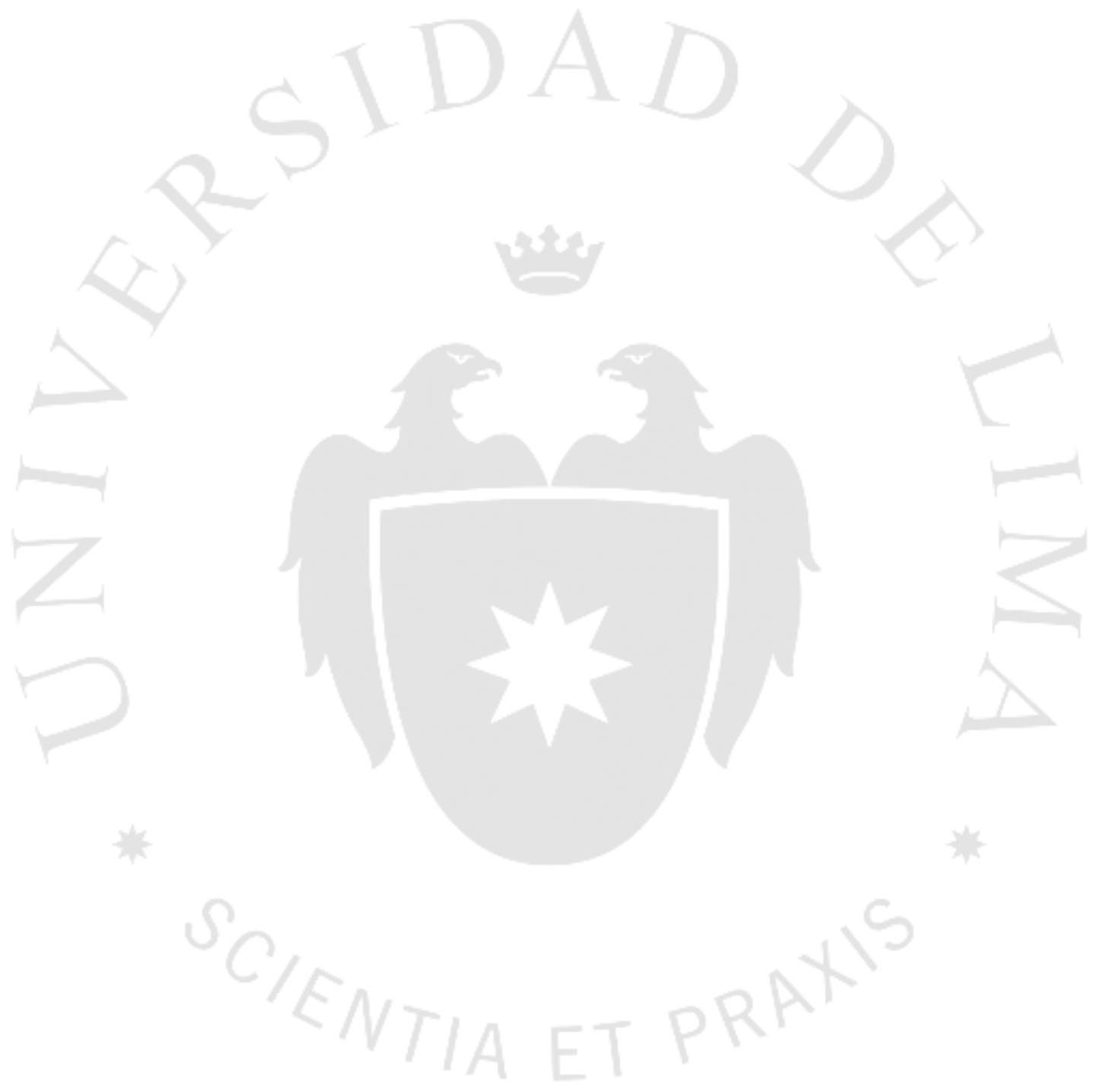




\section{JUSTICIA RESTAURATIVA: LA EVASIÓN NO VIOLENTA COMO UN NUEVO SUPUESTO DE REMISIÓN}




\section{TABLA DE CONTENIDO}

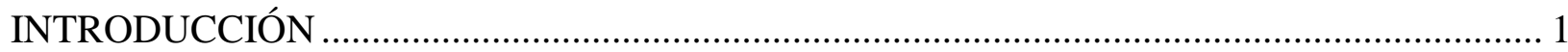

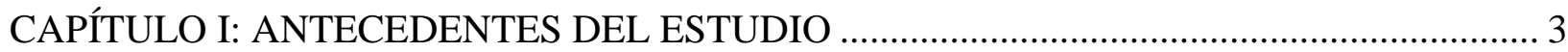

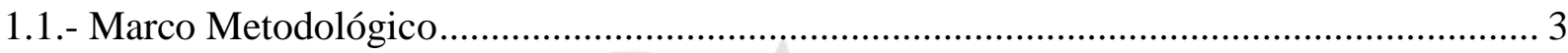

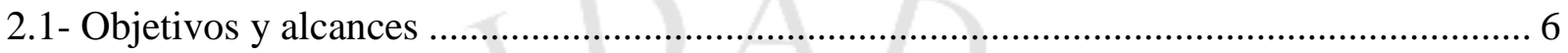

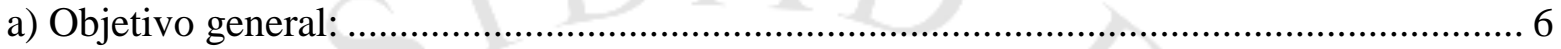

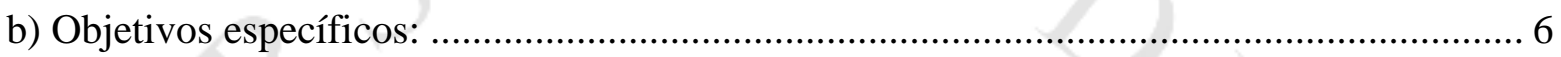

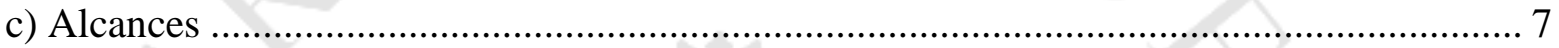

3.1.- Factores de riesgo determinantes para una posible actividad infractora de la ley penal .... 7

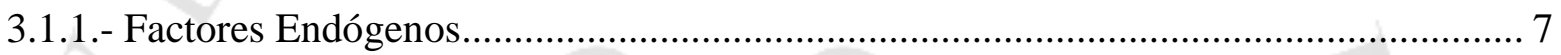

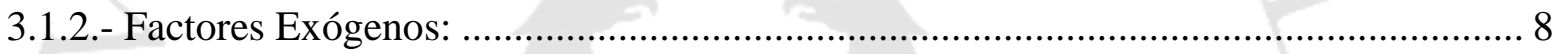

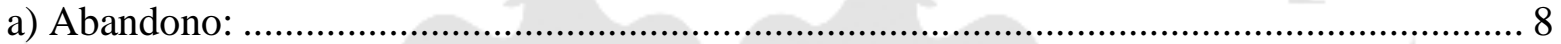

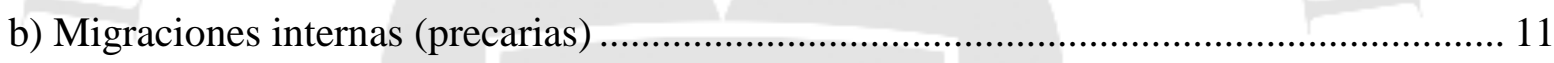

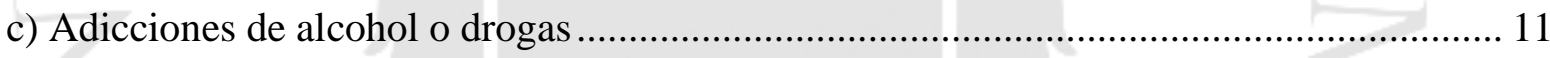

d) Victimización (mass media) ....................................................................................... 12

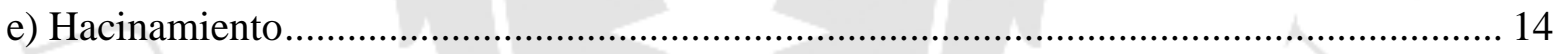

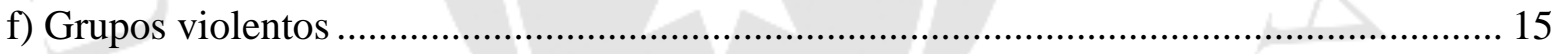

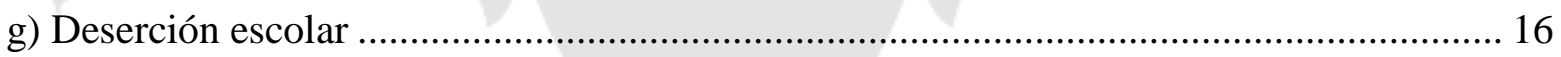

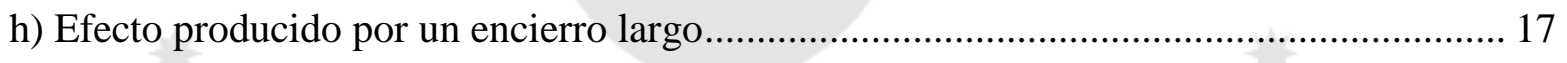

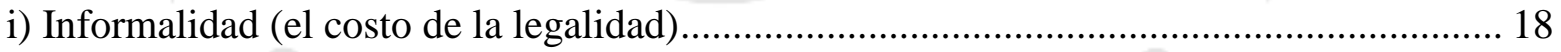

CAPÍTULO II: ALGUNAS RAZONES Y CONSECUENCIAS DEL ENCIERRO.................. 22

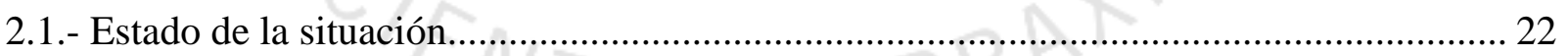

2.2.- Justificaciones estatales frente al estado de la situación ............................................. 22

a) Falta de recursos: excusa del ámbito administrativo ............................................... 22

b) El contexto de pobreza que contagia y agudiza la delincuencia o la infracción (Julián, el

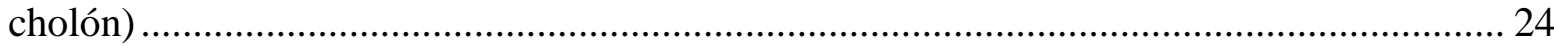

c) Hacinamiento y consecuencias de seguir con el mismo modelo. Una mirada a Brasil y al

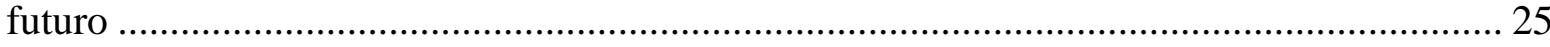

d) Efecto "Escuela del mal" (Contacto diferencial) ................................................... 28 


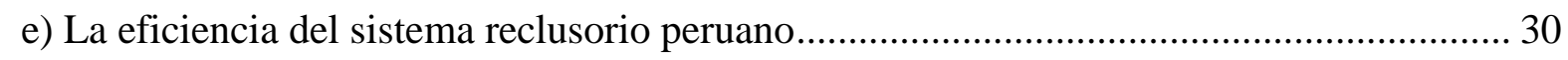

f) El abuso del poder como factor situacional (aplicación del análisis de Zimbardo)........... 33

2.3.- Inocuización y contención vs resocialización .................................................................... 35

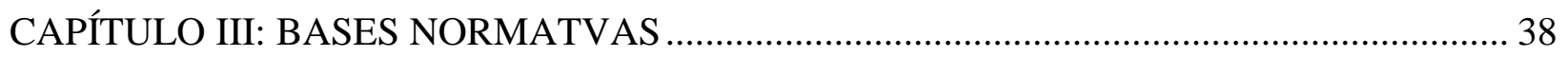

3.1.- La Constitución, análisis y respuestas de nuestro acervo normativo fundamental............ 38

3.2.- Estándares impuestos por la Organización de las Naciones Unidas, Organización de

Estados Americanos y la Corte Interamericana de Derechos Humanos.................................... 42

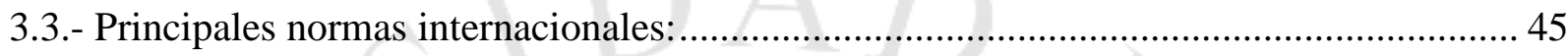

3.3.1.- Reglas Mínimas de las Naciones Unidas para la administración de justicia de

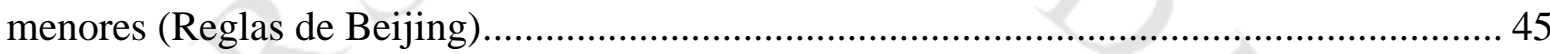

3.3.2.- Convención Americana sobre Derechos Humanos (Pacto de San José)..................... 48

3.3.3.- Convención sobre los Derechos del Niño ................................................................ 49

3.3.4.- Reglas de las Naciones Unidas para la protección de los menores privados de libertad

(Reglas de la Habana) ................................................................................................. 50

3.4.- Normas Administrativas en los Centros Juveniles de Diagnóstico y Rehabilitación de

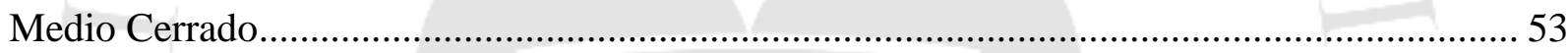

3.4.1.- Reglamento de Derechos, Deberes y Sanciones de los Adolescentes en Conflicto con la Ley Penal de los Centros Juveniles de Medio Cerrado del Poder Judicial......................... 53

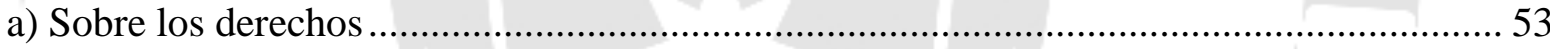

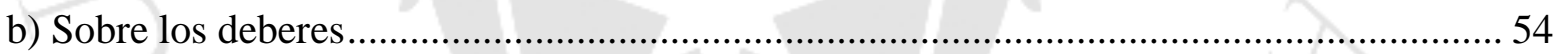

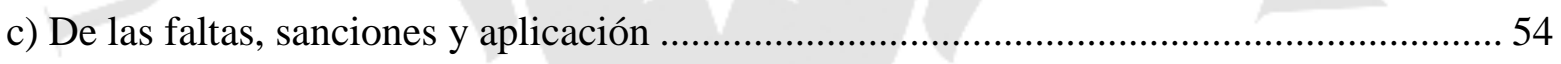

d) Respecto a la peligrosidad ............................................................................................. 57

3.4.2.- Normas y Procedimientos a Seguir en Situaciones de Fuga de los Adolescentes Infractores de los Centros Juveniles a Nivel Nacional ...................................................... 57

3.4.3.- Manual de Seguridad Integral al interior de los Centros Juveniles de Medio Cerrado a

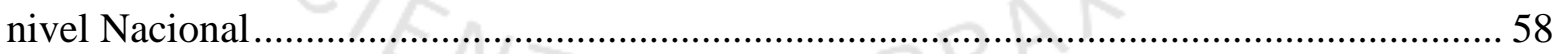

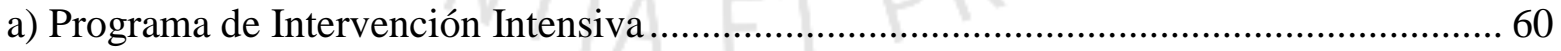

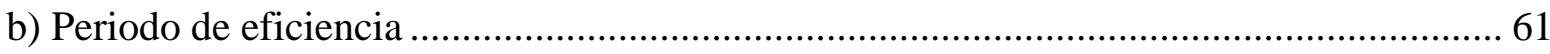

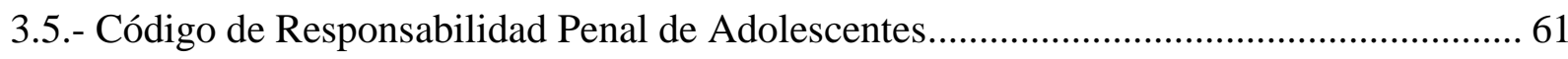

CAPÍTULO IV: COMPORTAMIENTO LEGISLATIVO Y PANORAMA JURISDICCIONAL

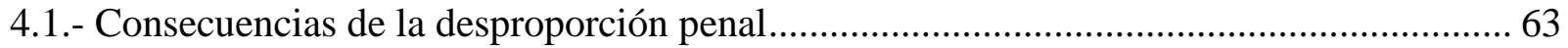

4.1.1) Medidas socio educativas más severas.......................................................................... 64 


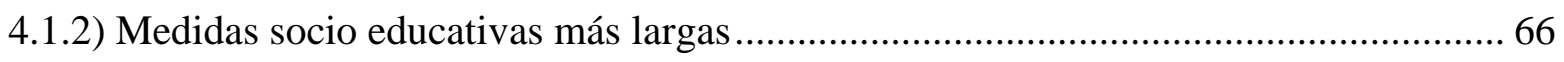

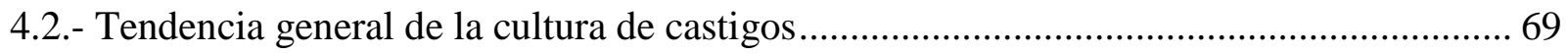

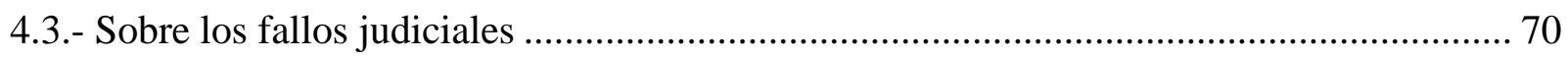

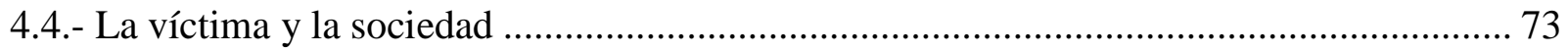

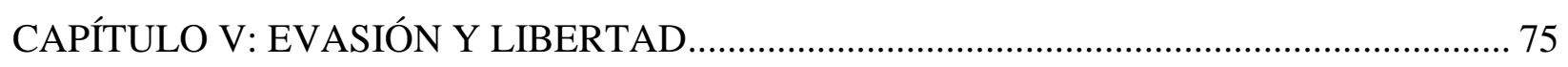

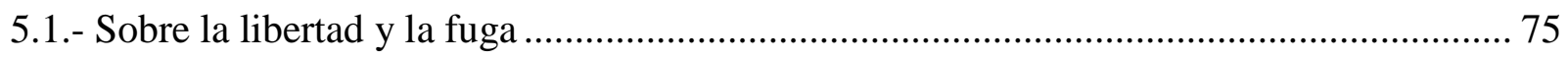

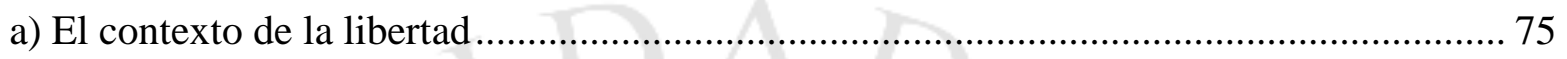

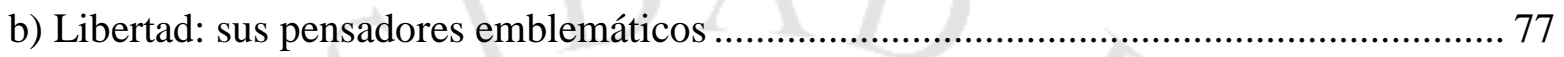

c) Interpretación del Tribunal Constitucional: libertad personal ........................................ 84

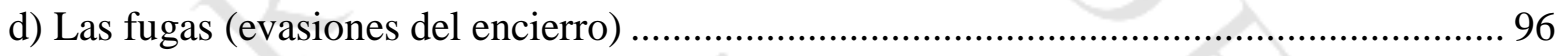

5.2.- Un desafío para el moralismo legal ...................................................................... 101

5.3.- La búsqueda de la libertad, conducta humana inherente a la naturaleza humana.......... 104

5.4.- Una salida oportuna: Cortar el medio de contagio y facilitar la sanación ..................... 105

5.5.- ¿Promueve la ley penal la fuga de los internos? .................................................... 109

5.6.- Enfoques criminológicos y económicos ............................................................... 116

5.7.- La integridad amenazada: un supuesto de estado de necesidad.................................. 121

CAPÍTULO VI: MEDIDAS SOCIO-EDUCATIVAS .................................................. 125

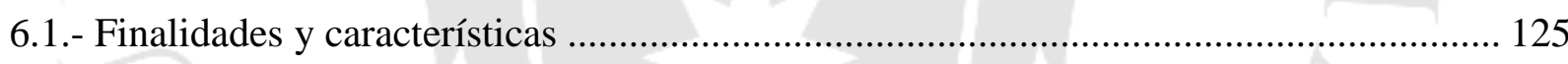

6.2.- Medidas socio-educativas (Decreto Legislativo núm. 1348, 2017)........................... 127

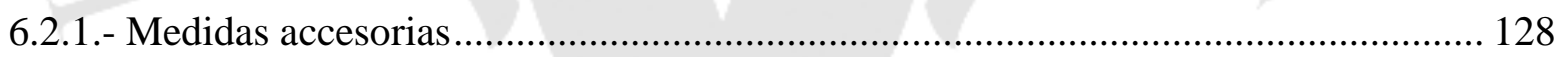

6.2.2.- Medidas socio-educativas no privativas de libertad.......................................... 128

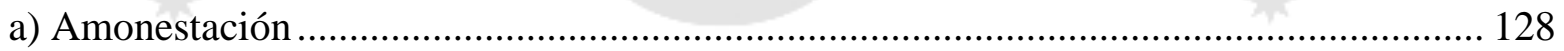

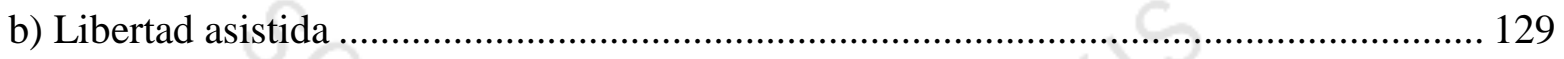

c) Prestación de servicios a la comunidad .................................................................. 129

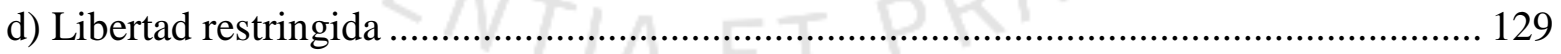

6.2.3.- Medidas socio-educativas privativas de libertad............................................ 131

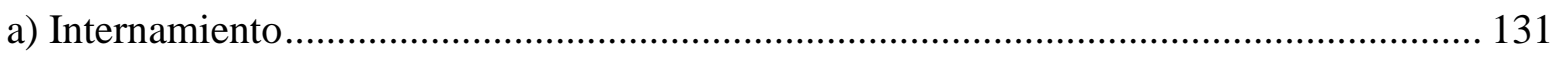

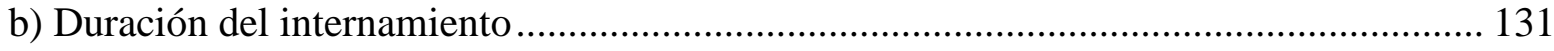

6.3.- Efectos del internamiento en el Código de los Niños y Adolescentes......................... 132

CAPÍTULO VII: JUSTICIA RESTAURATIVA .......................................................... 137

7.1.- Concepto y principales características .............................................................. 137 


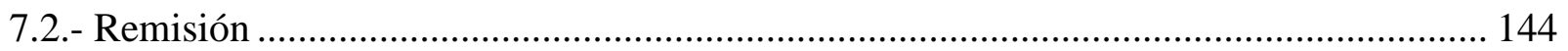

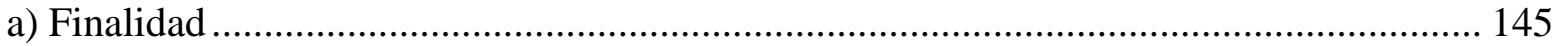

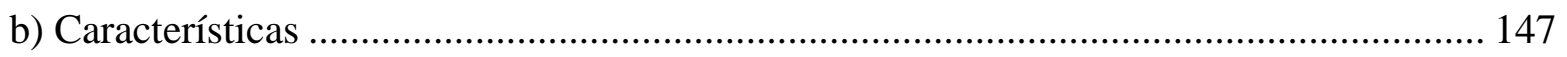

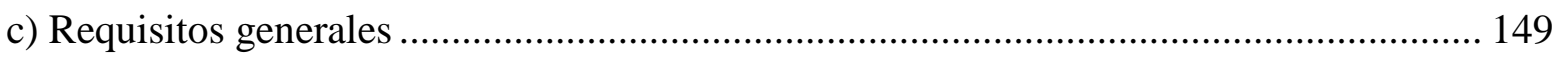

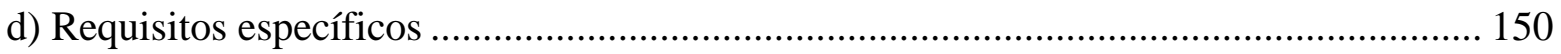

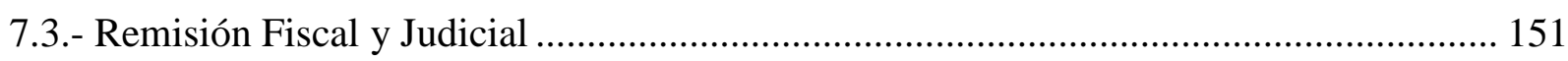

7.4.- Utilización de la Remisión en la Justicia Juvenil........................................................... 153

CAPÍTULO VIII: LÍMITES RACIONALES DE LA PROPUESTA ........................................... 155

8.1.- Cesare Beccaria: Utilidad más Necesidad. No para todos .............................................. 155

8.2.- Supuesto adicional de Remisión por fuga no violenta................................................... 160

8.3.- Fundamentos del nuevo supuesto de remisión................................................................ 164

8.4.- Requisitos para la implementación del nuevo supuesto de Remisión ............................... 168

8.5.- Límites racionales de la propuesta .......................................................................... 170

a) Gravedad de la infracción cometida ........................................................................ 170

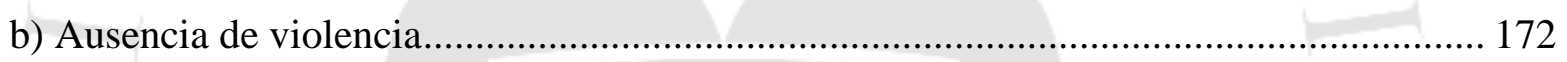

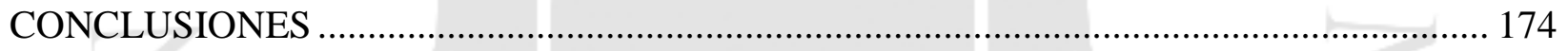

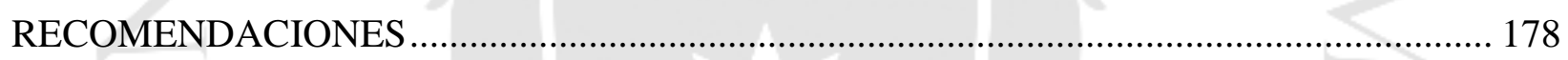

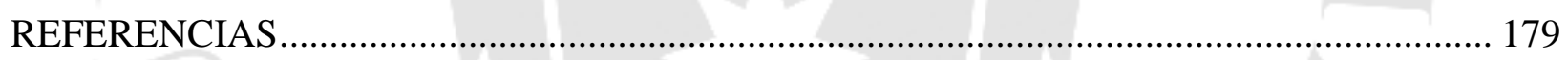

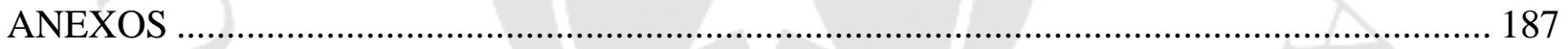




\section{ÍNDICE DE TABLAS}

Tabla 2.1 Capacidad de albergue y sobrepoblación............................................................... 26

Tabla 2.2 Población de adolescentes infractores del CJDR por programas y ambientes. ........... 27

Tabla 4.1 Motivo de ingreso de los adolescentes infractores a los CJDR a nivel nacional......... 64

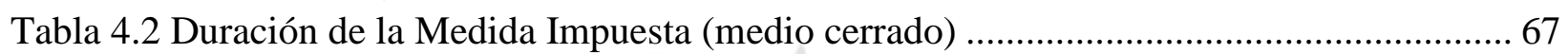

Tabla 5.1 Tipos de prevención. Una guía de políticas y acciones para cada tipo de prevención 107

Tabla 6.1 Pobreza: Población con la menos una necesidad básica insatisfecha, 2007 - 2015... 134

Tabla 6.2 Universidades: Número de graduados y titulados de Universidades, 1985-2014. .... 135

Tabla 7.1 Perú: Programa Estratégico: Justicia Juvenil Restaurativa del Ministerio Público. ... 141

Tabla 7.2 Justicia Retributiva y nuevo paradigma: Justicia Restaurativa.............................. 143

Tabla 8.1 Requisitos para no retornar al medio cerrado ................................................... 169 


\section{ÍNDICE DE FIGURAS}

Figura 1.1 Porcentaje de menores en estado de abandono. Perú (\%).

10

Figura 1.2 Perspectivas de prevención, administración de Justicia, resocialización y tratamiento

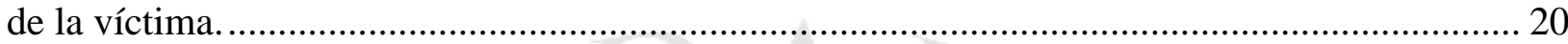

Figura 5.1 Población de 15 y más años de edad del área urbana, víctima de algún hecho delictivo

Figura 5.2 Robos o intento de robo en la vivienda en el Perú.

Figura 5.3 Población de 15 y más años de edad del área urbana, con percepción de inseguridad en los próximos doce meses, 2010 - 2016.

Figura 5.4 Tasa de homicidios en Latinoamérica 2014 (Por cada cien mil habitantes). ............... 94

Figura 5.5 Percepción Promedio de inseguridad por país, 2014 ................................................. 95

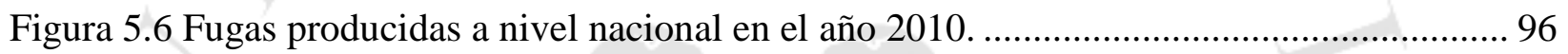

Figura 5.7 Fugas producidas a nivel nacional en el año 2011................................................. 97

Figura 5.8 Fugas Producidas a nivel nacional en el año 2012 ................................................. 98

Figura 5.9 Estadística de escapes en Piura............................................................................... 100

Figura 7.1 Medida Socioeducativa impuesta a los adolescentes en conflicto con la ley penal. . 154

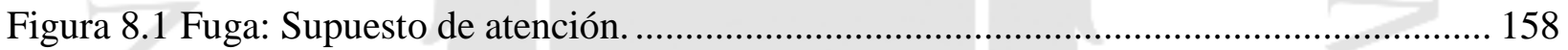

Figura 8.2 Esquema comparativo entre la Remisión y el nuevo supuesto de Remisión propuesto. 


\section{INTRODUCCIÓN}

Los lineamientos específicos que circundan la teoría que desarrolla el control social formal merecen un estudio crítico que permita hallar alternativas más eficientes, con reparación del objeto material dañado y la reintegración verdadera del sujeto activo en la sociedad. Por ello, en el sistema actual y frente a una vulneración de un riesgo prohibido, el Sistema Penal impone -en tanto el desvalor de la conducta merezca- una pena (medida socioeducativa) o medida de seguridad. Así también, el tratamiento posterior producto de la sanción penal supone la resocialización, reintegración y reinserción del infractor en la cotidianidad.

En ese orden de ideas, la sociedad ajena al origen, tratamiento y fundamento de la criminalidad, ha concertado en la necesidad del encierro para ciertas personas con la finalidad de contener una posible amenaza y evitar mayores contravenciones a los bienes jurídicos protegidos que permiten el desarrollo de la persona. $\mathrm{Y}$ en ciertos casos, sin importar en las consecuencias generadas por esta postura (sean ellas contraproducentes o eficientes), los castigos son efectivos, certeros y duraderos frente a la vulneración de algún riesgo prohibido.

En aquel contexto, esta tesis estudia un fenómeno relevante propio del internamiento en medio cerrado: la fuga de los Centros Juveniles de Diagnóstico y Rehabilitación.

Dicha premisa asume mayor relevancia para la teoría penal y criminológica, cuando aquella conducta de fuga, es realizada sin violencia por un adolescente interno en un medio cerrado por cometer una infracción que no revistió gravedad.

El supuesto precedente motivaron las siguientes preguntas: ¿Qué busca un joven infractor cuando fuga, desafío? ¿La conducta fuga es permitida por el ordenamiento penal vigente? ¿Qué bien jurídico se afecta cuando un adolescente escapa del medio cerrado? ¿De qué manera se atiende un caso de fuga? ¿En qué lugares el operador de captura logra recapturar a los adolescentes evasores del medio cerrado? Asimismo, ¿Qué constituye la acción de fuga; es una respuesta natural que incluye una protección frente a un riesgo certero, duradero, constante y de afectación directa a ciertos bienes jurídicos fundamentales?

Estas suposiciones llevaron a investigar una variedad de conceptos, teorías, experiencias y leyes. Toda vez que el internamiento en un medio cerrado es resultado de un Proceso Judicial, que 
es práctica ecuánime de los principios y garantías Constitucionales (tipicidad de la conducta, juridicidad del hecho, exigencias razonables sobre la culpabilidad del infractor, multiplicidad de medidas socioeducativas, alternativas diferentes al internamiento en medio cerrado, defensa idónea del menor, etc.).

Se revisa además normativa internacional vinculante, leyes nacionales penales y disposiciones administrativas vinculadas a la medida socioeducativa de internamiento en medio cerrado. Además, se utiliza doctrina especializada y de distintas ciencias (Derecho, Economía, Criminología, Psicología, Historia, Sociología, Antropología, Filosofía, entre otras). Así también, se analiza la implementación de la Justicia Restaurativa en el Perú; ello permitió concuasar los conceptos anteriores en una propuesta final que añade un supuesto adicional de aplicación a la Institución de la Remisión.

Por este motivo, el presente trabajo analiza dicho fenómeno desde diversas ópticas: analiza los factores de riesgo que llevaron al adolescente a cometer una infracción penal, las consecuencias del encierro en un medio cerrado, los efectos que se desarrollan en las personas que comparten en intensidad y durabilidad ciertas conductas, las circunstancias que se desarrollan con la medida socioeducativa de internamiento, los motivos de la conducta fuga, las alternativas normativas que permiten una rehabilitación, resocialización y reinserción adecuada.

Dividir la investigación en aquellos temas permitió atender el problema desde una perspectiva distinta a la acostumbrada en las investigaciones relativas a la ley penal; toda vez que la normativa punitiva observa sus campos de estudios desde el aspecto general (norma) hasta el enfoque particular (hecho jurídico). No obstante, para este trabajo, se toma como punto de partida el hecho particular de la fuga que cometen ciertos jóvenes albergados en un Centro Juvenil de Diagnóstico y Rehabilitación; el propósito fue adecuar la realidad observada a principios normativos actuales.

Finalmente, cabe la pregunta ¿Cuál es el fundamento de la medida socioeducativa de internamiento en medio cerrado, por cometer una infracción penal? Vista desde una finalidad preventiva general positiva, podría decirse que es evitar la comisión de nuevas vulneraciones sobre los riesgos prohibidos. No obstante, hallar la concordancia de esta directriz con la realidad, también es un motivo atractivo que esta investigación desarrolla. 


\section{CAPÍTULO I: ANTECEDENTES DEL ESTUDIO}

\section{1.- Marco Metodológico}

\section{a) Tipo de investigación}

Esta investigación surge de la inquietud, que se funda en la desesperación y necesidad de ayuda de los nuevos infractores de la ley penal. En esta investigación se observa la realidad y la contrasta con índices y números. Se analiza el problema desde lo particular hacia lo general. Es un problema que no se aloja solo en el mundo de las ideas y tampoco en de los símbolos; tiene una naturaleza compartida. En ese sentido, posee un enfoque mixto que recorre los caminos de lo cualitativo y cuantitativo; con mayor preferencia en el método inductivo. No se puede preferir alguno de los dos tipos de investigación ya que la posición generada no podría tener sustento, observamos de muy cerca la naturaleza humana y ello no puede ser medido, no existe una constante; por otro lado, sí resultan útiles los números para obtener índices de crecimiento, adaptabilidad y señales de operatividad que arroja todo sistema de castigo.

En consecuencia, se observó y se estudia el fenómeno de la fuga en los Centros Juveniles de Diagnóstico y Rehabilitación de Piura; toda vez que, en los años 2010, 2011 y 2012 se produjeron fugas recurrentes en aquella región. Por ese motivo, la investigación se interesa en el fenómeno fuga y el medio cerrado; identificando sus principales implicancias, principios, hechos y medidas adoptadas. Ello se expone con el propósito de confrontar el tratamiento posterior a la fuga que despliegan los operadores de control formal y la sociedad civil, en contraposición a los límites establecidos por las normas internas y también por aquellas normas internacionales con vinculación en la materia.

Además, se acudió a los autores de distintas ciencias como la psicología, historia, filosofía, economía y derecho para buscar una solución al hecho particular estudiado. Así también, para el aspecto cuantitativo de la investigación se acudió a la estadística brindada por la Gerencia de los Centros Juveniles de Diagnóstico y Rehabilitación que evidencia situaciones de descontrol, abuso y sometimiento desmerecido. 
En este trabajo tuvo el apoyo de un ex infractor que se encontró en un ambiente de encierro, se le identificará como "Alex". Su experiencia, se condice con las ideas que diferentes autores abordan en las razones u origen de la infracción penal y el desistimiento en la actividad infractora; ${ }^{1}$ además, Alex es el filtro entre la realidad y la teoría. Asimismo, su ayuda es determinante para concluir que un programa exitoso requiere de muchos recursos, atención especializada, constante y por, sobre todo, interesada.

Asimismo, se realizó una visita con acceso exclusivo a las instalaciones de los Centros Juveniles de Diagnóstico y Rehabilitación de Lima (Maranguita y Santa Margarita), ambos recorridos fueron guiados por funcionarios que facilitaron información e hicieron posibles interacciones importantes que se demuestran en el presente trabajo.

En suma, se lograron identificar las características más nocivas del sistema penitenciario peruano, para ello se tomó como universo el primer eslabón de la cadena del castigo, esto es, los Centros Juveniles de Diagnóstico y Rehabilitación.

\section{b) Nivel de investigación}

El grado de profundidad derivado de esta investigación, desarrolla las causas y consecuencias de las infracciones penales que conllevan un castigo en un medio cerrado, ellas se analizan desde distintas perspectivas y realidades. Verbigracia, se analiza el fenómeno de hacinamiento con la experiencia Pernambuco (Brasil), la nueva metodología que evita el incremento de las personas albergadas en un medio cerrado (Estado de Texas - Estados Unidos de Norte América), y la experiencia de la subcultura criminal juvenil en las pandillas de Centro América (Honduras). La profundidad de la investigación contempló doctrina de diversas partes del mundo, se utilizaron autores que comentan leyes o normativa penal, criminal y penitenciaria; además se consultaron textos que estudian el fenómeno de la criminalidad juvenil desde una perspectiva histórica, económica y filosófica.

Además, en el campo de la exploración, se visitaron los Centros Juveniles de Diagnóstico y Rehabilitación de Lima. En aquellos lugares el aprendizaje estuvo restringido y limitado por el secretismo y el cuidado que tiene el personal administrativo en no verse comprometido con los fenómenos recurrentes en un ambiente de encierro: abuso de poder, vulneración de derechos

\footnotetext{
${ }^{1}$ Para mayor información relativa al desistimiento en la actividad infractora y puntos de inflexión, consultar: Maruna, Shadd. (2001). Making Good. How ex-convicts reform and rebuild their lives. American Psychological Association Washington D.C.
} 
fundamentales, excesos en el castigo, etc. No obstante ello, se logró confirmar la postura desarrollada por la doctrina en los diferentes textos que se consultaron para esta investigación.

En ingreso a aquellos centros de encierro, o "medios cerrados", permitió describir el fenómeno de incapacitación (al que conlleva un modelo de encierro sin la adecuada implementación de los baremos internacionales); ello se desarrolla en el subcapítulo donde se aborda el Programa de Intervención Intensiva (PII).

Finalmente, la presente investigación no solo se limita a criticar el sistema de castigo en medio cerrado para menores de edad en el Perú, sino que además trata de explicar y aplicar una posible solución; se busca ampliar la práctica, poco conocida e implementada, de la Justicia Restaurativa.

\section{c) Procedimiento y desarrollo de la investigación}

El desarrollo del presente trabajo de Tesis tuvo el siguiente iter o recorrido:

a) El índice criminal se incrementa y pese a tener cárceles, policías en las calles y un sistema de justicia y penitenciaría, el crimen sigue existiendo e incrementándose. Por tanto, se buscó la razón ¿por qué existe el crimen?

b) Los medios de comunicación hicieron visible las fugas de los Centros Juveniles de Diagnóstico y Rehabilitación

c) El lugar en el que algunos menores eran encontrados y recapturados eran en sus hogares. Esto fue elemental para el desarrollo de la tesis. Este punto fue el motivo de la curiosidad.

d) Se estudió la realidad punitiva en nuestro país. Sus bemoles y aciertos.

e) Se consultó a la Gerencia de los Centros Juveniles de Diagnóstico y Rehabilitación, allí brindaron estadísticas e información relevante.

f) Se buscó el origen y matices del problema criminal. Bases criminológicas, filosóficas, históricas y económicas.

g) Se consultó la normativa internacional de las principales instituciones ligadas al crimen. ONU, OEA, CIDH.

h) Se consultó la normativa aplicada al régimen de menores. Reglas de Beijing, Reglas de la Habana, la Convención Americana sobre Derechos Humanos, Convención sobre los Derechos del Niño, y el Código Penal Juvenil. 
i) Se estudiaron las normativas administrativas de los Centros Juveniles de Medio Cerrado: Reglamento de Derechos, Deberes y Sanciones de los Adolescentes en conflicto con la Ley Penal de los Centros Juveniles de Medio Cerrado del Poder Judicial. Las Normas y Procedimientos a seguir en situaciones de fuga de los adolescentes infractores de los Centros Juveniles a nivel nacional. Manual de Seguridad Integral al interior de los Centros Juveniles de Medio Cerrado a nivel nacional.

j) Se consultó amplia doctrina relacionada a política criminal, nacional e internacional.

k) Se entrevistó a una persona que representa un caso exitoso de resocialización (por medida socio educativa), con la finalidad de verificar y contrastar la información proporcionada por los autores y funcionarios públicos.

1) Se visitó el Centro Juvenil de Diagnóstico y Rehabilitación para mujeres (Santa Margarita).

m) Entrevista con la directora del Centro Juvenil de Diagnóstico y Rehabilitación para mujeres (Santa Margarita).

n) Entrevistas con Fiscales del Ministerio Público.

\section{1- Objetivos y alcances}

Proponer una alternativa que evite el internamiento en el medio cerrado de los adolescentes en conflicto con la ley penal. Más aún cuando el infractor no comete una vulneración que implique violencia o daño a un bien jurídico protegido de mayor relevancia. Ello en un contexto de fuga no violenta y amparada en un comportamiento humano justificado por el derecho penal.

\section{a) Objetivo general:}

Estudiar el internamiento en medio cerrado de los jóvenes en conflicto con la ley penal y relacionar sus principales matices con el fenómeno de fuga.

\section{b) Objetivos específicos:}

Utilizar la institución de la Remisión, con la finalidad de evitar el internamiento del adolescente que no dañó un bien jurídico relevante y que fuga sin violencia de un Centro Juvenil de Diagnóstico y Rehabilitación. En suma, se propone una nueva opción para aplicar este mecanismo que evita que el adolescente infractor tenga algún contacto con el Sistema Penal; de manera específica se busca que no se genere mayor contacto entre el adolescente fugado y el medio nocivo, que representa la privación de libertad mediante el internamiento en un medio cerrado. 


\section{c) Alcances}

Esta investigación propone ampliar el campo de investigación en el problema que circunda el internamiento de jóvenes en el medio cerrado. De esa manera, busca mejorar la visión de todos sus matices: aciertos, desaciertos y consecuencias.

\section{1.- Factores de riesgo determinantes para una posible actividad infractora de la ley penal} ¿Por qué los jóvenes cometen infracciones penales? Para iniciar con este capítulo del trabajo y responder aquella pregunta esencial, es necesario establecer los diferentes orígenes que llevan a una persona a ingresar al mundo criminal.

Es constante la falta de acceso a la información, se ataña en falta de interés, ausencia de transparencia; en contraposición a las abundantes campañas de victimización lideradas por los medios de comunicación y también aquellas campañas promocionadas por políticos que intentan conseguir sus objetivos a través de propuestas fundadas en miedo y radicalismo.

En las últimas dos décadas, el Estado Peruano ha implementado una política punitiva y represiva que se ha traducido en el incremento de penas o reducción de beneficios penitenciarios como "política criminal" frente al delito. Las estadísticas en ese mismo periodo nos muestran que dicha fórmula no ha tenido, al menos en el ámbito de la prevención o disuasión, efecto alguno. Por el contrario, el resultado de esta política de corto plazo, coyuntural y populista, ha sido el hacinamiento penitenciario $\mathrm{y}$, con ello, la imposibilidad de un adecuado sistema de reinserción social.

(Consejo Nacional de Política Criminal, 2014, p.9).

De manera acertada, Shavell condensa los distintos orígenes del crimen en una premisa:

(...) los criminales vistos como clase parecen tener relativamente poca riqueza. Y esto no es sorprendente, porque muchas de las características personales relacionas con la criminalidad -por ejemplo la falta de escolaridad y el abuso de drogas y alcohol- se encuentran ligadas a la incapacidad de ganar un salario. Además, una motivación primaria para cometer algunos delitos, en especial estafas, robos y asaltos, es presumiblemente que los individuos tienen pocos ingresos. (Shavell, 2000, pp.383-436).

\subsection{1.- Factores Endógenos:}

Son aquellos determinados por los factores internos que cada persona posee, su información genética, los factores hereditarios y trastornos psicológicos que concurren en la actividad criminal. Cabe mencionar que esta posición era desarrollada por el Positivismo Criminológico (Pavarini, 2003); no obstante, la presente tesis no comparte esta posición. Sin embargo, se considera importante nombrar esta tendencia Positivista; más aún, porque existen todavía posturas derivadas 
del Positivismo que intentan abordar y explicar el crimen a partir de las características propias del sujeto que no cumple con las normas de control social (Etiquetamiento Criminológico / Interaccionismo Simbólico).

Según los primeros estudios realizados a principios del siglo XX, los factores que condicionaban la criminalidad de los menores de edad eran los genes hereditarios, el proceso de gestación, los trastornos mentales que pueden padecer y las deficiencias psíquicas y físicas. Se determinaba una prioridad de los factores estáticos frente a los dinámicos... en la actualidad ya no se les considera factores directos de criminalidad, pues los genes van a necesitar complementarse con los factores dinámicos para convertirse en causales directos de comportamientos delictivos de los niños y adolescentes... Los trastornos psicológicos son considerados como un factor predictivo de la criminalidad por las escuelas contemporáneas. Existen nuevos factores estáticos desarrollados por la doctrina contemporánea que se consideran que tienen influencia en la conducta del niño o adolescente en conflicto con la ley penal, entre los cuales se encuentran la edad y el sexo.

(Valencia, 2017, pp.132-135).

\subsection{2.- Factores Exógenos:}

Son aquellos factores de riesgo que se enfocan en los elementos que rodean al menor infractor. "Son aquellas influencias externas que se presentan durante su desarrollo y marcan una característica en su personalidad. Entre estos factores se encuentran las relaciones familiares, la escuela y el entorno, que incluye al barrio y a los medios de comunicación.” (Valencia, 2017, p.137) En ese sentido, a continuación, se desarrollan los factores de riesgo más importantes de la actividad criminal en menores.

\section{a) Abandono:}

Muchos de los jóvenes infractores provienen de un estado de abandono, en algunos casos, viven con algún familiar o simplemente radican en la calle, en grupo con otros menores que tampoco tienen vivienda. Existe en el Perú un número importante de menores en estado de abandono "Según información del INABIF, se calcula que en el Perú existen aproximadamente 17 mil niños y niñas y adolescentes en abandono, albergados en Centros de Atención Residencial tanto públicos como privados" (Defensoría del Pueblo, 2017).

Al respecto, la Defensoría del Pueblo en su informe titulado "Niños, niñas y adolescentes en abandono: aportes para un nuevo modelo de atención" determinó que existían 144 niños, niñas y adolescentes en presunta situación de abandono y aptos para el procedimiento de adopción. Siendo 80 de sexo femenino y 64 masculino (Defensoría del Pueblo, 2011). 
Para el año 2015 este porcentaje se incrementó: 302 niños ubicados en albergues del Programa Integral Nacional para el Bienestar Familiar del INABIF (El Comercio, 2015). No obstante ello, existe un grupo mayoritario de 15 mil menores que esperan por un proceso de adopción y que aún no son declarados “en abandono” (Perú21, 2014).

En diferente orden de ideas, también ocurre que el operador de justicia considere que un adolescente estará mejor en un centro juvenil (también por cometer infracciones leves, que solo merman patrimonio sin violencia). Ello trae como consecuencia -para algunos casos específicosefectos nefastos para el desarrollo de dichos jóvenes. Ya que deberán estar encerrados por largas temporadas, en un medio donde priman la violencia, el riesgo y el abuso de poder.

En adición y a modo de crítica: en el Centro Juvenil para mujeres, Santa Margarita, no se admite la visita de los padres de familia a los niños que nacen en aquel recinto penitenciario (solo se permite el ingreso a los esposos de estas menores; no es posible en nuestra sociedad casarse a los 14 años de edad). Los niños entre 1 y 3 años crecen en el universo alterno donde no conocerán la figura paterna hasta alcanzar los 3 años de edad; en un tiempo tan largo es posible que el padre cultive otra relación o compromiso con otra pareja y que no quiera mantener ningún vínculo con un niño que él no conoce ni desarrolló afecto. El niño de tres años que debe salir del centro juvenil, sin padre y obligado separarse de mamá a corta edad, no se podrá desarrollar del modo habitual y deseado.

Ello también genera otra consecuencia no deseada y contraproducente, ya que lleva a formar una familia no convencional y con mayores necesidades: “(...) allí donde la familia sostenida por una madre que vive sola, la pobreza es por lo menos tres veces mayor que en las familias tradicionales" (OIT, 2000, p.3). 
Figura 1.1.

Porcentaje de menores en estado de abandono. Perú (\%)

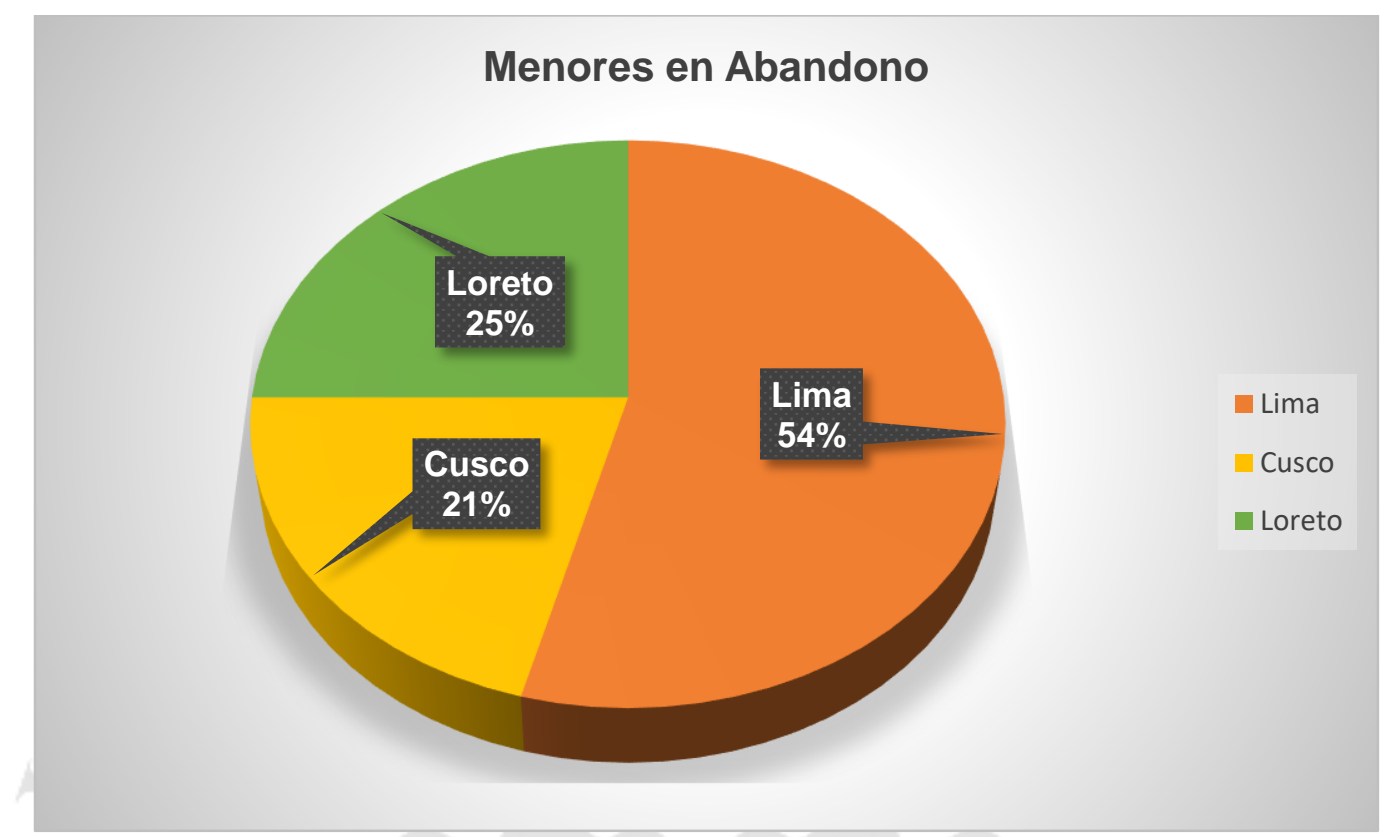

Nota: Para el año 2011, en Lima se encontraba un 54\% de menores en estado de abandono Fuente: Defensoría del Pueblo. (2011). Niños, niñas y adolescentes en abandono: aportes para un nuevo modelo de atención. Perú: Serie de Informes Defensoriales. Informe $\mathrm{N}^{\circ} 153$. Recuperado de: http://www2.congreso.gob.pe/sicr/cendocbib/con3 uibd.nsf/7FB8E8BD618BB73A0525790400782FEF/\$F ILE/ID-153_Informe_Defensor\%C3\%ADa del_Pueblo.pdf

El abandono se considera uno de los orígenes del crimen ya que muchos de los niños abandonados son utilizados por mafias criminales. Así también, forman grupos con otros menores y en un medio sin educación, límites, protección, ni dinero, son convencidos por la idea de obtener bienestar de una manera rápida y sin mayor esfuerzo. En un contexto de esa naturaleza, cualquier persona en un estado de abandono, representa una oportunidad para que la sociedad demuestre sus valores altruistas, pero también representa un riesgo, ya que el menor en un estado de abandono tratará de satisfacer sus necesidades básicas y llegado un momento de crisis es posible que se vea seducido por la idea de cometer actos ilícitos para lograr sus objetivos. No toda persona abandonada representa un peligro, pero es un factor de riesgo para desarrollar conductas asociales.

El fundamento de esta grave personalidad antisocial se halla en el hecho de ser un niño no deseado y criado en un hogar inestable con situaciones muy negativas y que ha sufrido malos tratos. Como consecuencia de lo anterior surge la drogadicción como única vía de escape. También este estudio destaca que esta tipología de delincuentes juveniles refiere un peculiar odio a la policía y a los animales. Sus frustraciones proceden de la falta de amor materno. Dado el anterior historial, aunque no sólo por ello se justifica, suelen presentar una cierta insuficiencia intelectual, así como una tendencia a sufrir enfermedades acumuladas. 
(Brage Cedán, 2013, p.107).

\section{b) Migraciones internas (precarias)}

En el libro los Hijos del Orden de Urteaga (2014), se elabora un estudio -a manera de crónicadonde determina que la migración interna, que sucede con frecuencia en el país, debe ser considerada como un factor de riesgo importante; por tanto, sugiere atención a los traslados y desplazamientos internos sin seguridad que expone a los menores de edad a ser víctimas y también a conducirlos por situaciones extremas que posiblemente los acerquen al mundo criminal.

Él identifica como un origen del crimen al "centralismo": las personas deben de migrar desde diferentes puntos de nuestro país para conseguir buena educación y obtener mejores remuneraciones; es también una esperanza para alcanzar sueños y metas. En ese camino, las personas se pierden, llegan niños, adolescentes solos, sin familia a buscar dinero. Deben romper bastantes barreras, como las del idioma, el racismo, una nueva ciudad, demasiada población, la soledad.

En un momento de crisis, encuentran en el crimen una solución pronta a sus problemas. Sus métodos mejoran y se convierten en jóvenes criminales que en algún momento son encerrados en Centros Juveniles de Diagnóstico y Rehabilitación. En consecuencia, la prevención debe de seguir ese espíritu, evitar el desplazamiento masivo, crear oportunidades de crecimiento en cada región del Perú, unificar y fortalecer a cada Departamento del país. Debemos evitar que menores viajen solos a Lima, o a las grandes ciudades, ello supone una exposición al crimen y sus consecuencias.

Es necesario resaltar que este factor de riesgo genera la mendicidad infantil en las calles de la ciudad. Una práctica valiosa sería que los miembros de la sociedad los acojan y cuiden; ello requiere una agilización en el proceso de adopción y creación de más lugares privados (asociativos) en los que los niños que viven en la calle puedan dormir, estudiar y alimentarse.

\section{c) Adicciones de alcohol o drogas}

Es menester distinguir dos tipos de delincuencia relacionada al consumo del alcohol y las drogas. La primera es la Delincuencia Funcional que es ocasionada por una enfermedad adictiva; las personas necesitan consumir alcohol o droga y para ello cometerán delitos que les permitan lograr su objetivo. 
En cambio, la Delincuencia Relacional o Periférica es desarrollada por aquellos que cumplen un rol dentro de la estructura organizacional de la droga, es decir, la transportan, venden, vigilan o preparan; algunos no son consumidores. "DEVIDA en el año 2009, se podía advertir que $6 \%$ de los escolares varones de secundaria consumió algún tipo de droga ilegal y el $32.7 \%$ consumían algún tipo de alcohol o tabaco. En el caso de las mujeres, el 3\% consumió drogas ilegales y el 25.2\% había consumido alcohol o tabaco" (Consejo Nacional de Política Criminal, 2014, p.54).

La misma institución brindó información relativa al momento de la comisión del delito, ella forma parte de la Delincuencia Funcional: "Así, cifras de DEVIDA al 2009, indican que el $6.4 \%$ de los infractores encuestados afirmó haber consumido drogas el mismo día en que cometió la infracción; y un 7.9\%, al menos una droga o alcohol" (Consejo Nacional de Política Criminal, 2014, p.55).

En ese sentido, las adicciones representan un importante punto originario de la criminalidad. La sociedad las considera como un simple vicio o característica de la personalidad; sin embargo y acorde a la Organización Mundial de la Salud (OMS) es una enfermedad. Por tanto, las personas enfermas que ocasionan daños o cometen crímenes con el propósito de satisfacer a su adicción, deben de recibir tratamiento, no un castigo. La rehabilitación y la resocialización son conceptos diferentes.

Re-habilitar según la RAE es volver a hacer a alguien o algo hábil, apto o capaz para una cosa determinada (RAE, 2018); en cambio re-socialización es la acción de socializar ...adaptar a un individuo a las normas de comportamiento social (RAE, 2018). Por tanto, pretender castigar a enfermos y juntarlos en un medio por personas asociales, trae consigo consecuencias nefastas. Para lograr satisfacer su adicción, el enfermo hará todo lo necesario para procurar su consumo. Se convierten en un medio, una herramienta para los criminales más experimentados que los usarán para cometer delitos violentos a cambio de un consumo periódico mínimo; estas personas pierden su identidad y el gobierno de sus vidas (aquí una fuente de análisis es la autoría mediata de la que se ocupa la teoría penal al tratar sobre la intervención delictiva).

\section{d) Victimización (mass media) ${ }^{2}$}

\footnotetext{
${ }^{2}$ Medios de comunicación masiva.
} 
Los medios de comunicación o "mass media", cumplen un rol muy importante en la lucha contra el crimen, ellos vigilan, denuncian y luchan en nombre de la libertad de expresión para evidenciar situaciones muy graves. Así también, son los responsables de generar un nivel de victimización exacerbado, amarillista y distante de la realidad.

El objetivo de muchos medios de comunicación -en mayor grado televisivos y radiales- es aumentar su audiencia a través de noticias sensacionalistas, con alto grado de morbo y con bajo contenido moral; uno de sus objetivos principales radica en crear "tendencia" (personas hablan de un tema específico, y a través de sucesos criminales muy nocivos se consigue la atención del público). Esa búsqueda de "tendencia" a través de la victimización ocasiona una idea distorsionada de lo sucede en realidad.

Es decir, crímenes muy graves han sucedido y suceden con frecuencia, no obstante ello, algunas en menor cantidad y en menor proporción respecto de aquellos delitos (o infracciones) de escasa relevancia y cuyo objeto jurídico fue de carácter patrimonial (y/o los conocidos como de cuello blanco). Por tanto, aquellas comunicaciones que imponen en las personas ideas de inseguridad, desconfianza, individualismo y sobreprotección ocasionan distorsión de la realidad criminal de la sociedad. ${ }^{3}$ Genera además, que las personas acudan a otras medidas de seguridad, a veces extremas, como el empleo de armas de fuego; y frente a un ataque pequeño (dirigido a disminuir patrimonio) la persona, alarmada y armada, reaccionará de manera desmedida, ya que cree que será atacado y quizás gravemente herido. Algunos casos de protección exacerbada y desmesurada han desvirtuado el principio de proporcionalidad. La sociedad retrocede y solicita el retorno a la pena de muerte, al empleo de castigos degradantes e inhumanos. "Hasta el 2003, matar en defensa propia exigía el criterio de la proporcionalidad de medios. Hoy se puede matar por salvaguardar la billetera o la cartera, y está bien hecho. (...) Creer que para no ser víctima de la violencia hay que emplear la violencia aplicando justicia por mano propia, implica un retroceso civilizatorio" (Aguilar, s.f., p.215).

Ahora bien, si cada persona ("potencial víctima de asesinato") emplea un arma para defenderse, envía un mensaje directo a los delincuentes, y éstos aplicarán el riesgo muerte a la satisfacción de su actividad. Estarán preparados para morir, pero también para matar. Se debe resaltar que no se intenta disuadir a los medios de comunicación o eliminar la libertad de expresión,

\footnotetext{
${ }^{3}$ Ver Figura 5.4 Tasa de homicidios en Latinoamérica 2014 por cada cien mil habitantes, y Figura 5.5 Percepción promedio de inseguridad por país 2014.
} 
por el contrario, se desea que la información sea veraz, con el objetivo de buscar la paz social, la no violencia y mucho menos la re-victimización.

Se debe brindar información real, contratada para orientar a la solidaridad:

(...) el descuido de la información puede generar estigmas subliminales que permanecen indelebles durante toda la vida en la sociedad, generando una falta de corresponsabilidad de esta para con aquellos, lo que ha determinado una falta de interés en el tratamiento diferenciado del adolescente, exigiendo por el contrario mayores sanciones o traslados de los centros juveniles a los lugares más alejados de su entorno social.

(Consejo Nacional de Política Criminal, 2014, p.43).

En ese sentido, el pedido de mayores sanciones acarrea sanciones penales más duras y largas, ello indefectiblemente crea niveles de hacinamiento extremo, y con ello, la imposibilidad de implementar un plan eficaz de resocialización. Las personas deben interesarse por el mundo criminal, ello conlleva a tener mejores prácticas y la obtención de resultados deseados.

\section{e) Hacinamiento}

Es propicio comenzar este literal con la crítica respecto al hacinamiento que realiza el Consejo de Política Criminal del Ministerio de Justicia (2014):

Toda sobrepoblación trae consigo un elevado índice en el deterioro de las instalaciones, menores posibilidades de atención de los adolescentes en conflicto con la ley penal por el déficit de los equipos profesionales y técnicos, a fin de posibilitar su resocialización. Es en este escenario donde se producen dos grandes efectos: i) sobre los adolescentes en estado de hacinamiento: conflictos internos (motines, grescas y reyertas); ii) sobre los liberados: reincidencia y reingreso. (p.87).

Al respecto Zaffaroni, precisó que: “(...) De esta manera, si yo estoy en un establecimiento que tiene más ocupantes de los que caben en él, me dan de comer menos de lo que necesito para vivir, y no me dan atención médica, están agravando indebidamente mis condiciones de detención (...)” (1993, Párrafo 47). Y no solo se están agravando las condiciones de la detención, sino que se hace imposible ejecutar la finalidad de la medida correctiva; que es la resocialización. Si los menores cuentan con menos tiempo de atención de los psicólogos y educadores no hay manera de obtener el éxito en los programas/módulos de resocialización.

Encontramos por ello dos vertientes, una que atañe a la esfera individual -del detenido- y otra que nos incumbe a todos los que conformamos la sociedad. La primera implica la lejanía de la resocialización y con respecto al impacto que tiene en el segundo ámbito: los criminales adultos 
obtienen una especialización, muy cercana a lo que se define por profesionalización del crimen y se puede extrapolar ese dato del conocimiento general a la situación de los menores bajo encierro. Debemos evitar llegar a ese punto, frenar y disminuir el hacinamiento por reducir también el impacto nocivo y los márgenes de criminalidad.

Aunque en la práctica nada hay más atroz que nuestros sistemas penales, formalmente no podemos aceptar las penas atroces. Nuestros sistemas penales se han introyectado en el equipo psicológico de quienes participamos de la civilización industrial, y en buena medida han devenido objetos de fe. (...) El poder punitivo ha venido a usurpar el lugar de Dios: lo puede todo. Es un ídolo y, como tal, tiene sus fanáticos, sus seguidores enceguecidos, que frente a cualquier conflicto, de la naturaleza que fuere, de inmediato procuran la solución punitiva, lo ponen en manos del sistema penal, con lo cual lo privan de su naturaleza y, por lo tanto, de cualquier posible solución efectiva. (Zaffaroni, 2012, p.26).

Finalmente, Muñoz Conde (2012) elabora un conciso análisis al respecto, este tema será ampliado en otra sección del trabajo (Capítulo III, numeral 5):

Es verdad que la cárcel cambia al delincuente, pero generalmente lo hace para peor. No le enseña valores positivos, sino negativos para la vida en libertad. Por eso, no es extraño que al final de su estancia en la prisión salga de ella muchas veces peor que cuando entró; es decir, desocializado y estigmatizado, incapaz de llevar en libertad una vida sin delitos. Además cuando sale al exterior después de haber cumplido su pena, sale a un mundo que, fuera de los muros de la cárcel, ha seguido evolucionando conforme a sus propias leyes y que, en lugar de abrir los brazos y darle una oportunidad para rehacer su vida, mira al ex recluso con recelo, cuando no con clara desconfianza respecto a lo que vaya a hacer en el futuro. Ciertamente, las leyes penitenciarias más avanzadas y la praxis de los concretos centros penitenciarios procuran de diversas formas facilitar el paso a la libertad, potenciando la paulatina vuelta a la misma con los permisos penitenciarios y el régimen de semilibertad de los sistemas abiertos antes de conceder la libertad condicional y, posteriormente, la definitiva, pero evidentemente esto no es suficiente para conseguir la plena reinserción social del que acaba de salir de un centro penitenciario después de haberse pasado en él un buen número de años. (p.175).

\section{f) Grupos violentos}

“Así, por ejemplo, una investigación de la Universidad de Pittsburg estableció tres trayectorias para el desarrollo criminal, donde el primer camino se muestra con "una agresión menor", como el caso de molestar o amedrentar a otros; seguido por peleas con enfrentamientos físicos y verbales; y culminando con delitos violentos” (Consejo Nacional de Política Criminal, 2014, p.40).

La violencia como factor contributivo y moderador de conductas, configura un círculo negativo de renovación automática, donde cada falencia implica un engranaje menos en el mecanismo que busca la disminución del factor criminal. El crimen no es un tema ajeno o exógeno de la sociedad, más bien le pertenece, puede modificarlo y tiene directa proporción con la 
incumbencia y compromiso de las personas que la conforman: “(..) violencia incrementa los costos de los programas sociales a nivel de prevención primaria, reduce la productividad del país, disminuye el valor de la propiedad y, en especial, deteriora la estructura de nuestra sociedad" (Consejo Nacional de Política Criminal, 2014, p.7).

\section{g) Deserción escolar}

Para el año 2012, el 15.9\% de los menores infractores que se encontraban en algún Centro Juvenil ingresaron con un nivel de instrucción de primaria incompleta, y el 59.7\% con la secundaria incompleta (Consejo Nacional de Política Criminal, 2014). En algunos casos, una medida socio educativa también representa interrumpir los estudios escolares o universitarios, lo que resta oportunidad de progreso y resocialización.

Asimismo, en el Plan de Prevención del Consejo Nacional de Política Criminal (2014) que sirve de guía para esta investigación, también se determinó que:

(...) los niveles de pobreza y el desempleo aún siguen siendo un problema en nuestra sociedad y muchos jóvenes son conducidos a buscar trabajo para mejorar el ingreso familiar. Sin embargo, las consecuencias de un precoz ingreso al mundo laboral por parte de los adolescentes en edad escolar

trae consigo, no solo la deserción escolar y con ello un normal desarrollo intelectual; sino también al acondicionamiento de los mismos a trabajos no calificados, de bajo nivel y escasamente remunerados. (p.66).

Grados ínfimos de preparación generan escaza competitividad, ello reduce las oportunidades laborales y como consecuencia, las labores más simples y menos remuneradas serán las más óptimas para el grupo con menores niveles de estudios académicos. Sin embargo, las necesidades establecidas por la sociedad (Factor: aspiraciones determinadas por la Sociedad), generan en el individuo la inquietud: de conseguir u obtener lo que el promedio goza y tiene (Presión Anómica). No obstante, la sociedad está conformada por diferentes perfiles de personas con capacidad adquisitiva distinta, variada escala social/cultura (Factor: estructural). Es decir, son claros los objetivos de la sociedad: lograr bienestar social, económico y cultural; sin embargo, el camino para alcanzar estos objetivos no es determinado, y algunos sectores de la sociedad se encontrarán muy lejos de lograrlos. Por ello y frente a la lejanía en la obtención de los objetivos sociales, algunos buscarán satisfacer sus necesidades afectando bienes jurídicos protegidos de otras personas. En consecuencia, algunas personas, a través del esfuerzo y vías óptimas lograrán 
sus objetivos; sin embargo, otros, buscarán medios ilícitos para alcanzar las metas socialmente aceptadas (Downes, D. Rock, P. And Mclaughlin, E., 2016).

Quienes piensan y sienten son únicamente los individuos: son ellos y nada más que ellos los que buscan placer y huyen del dolor. El individuo es, él mismo, un todo, y a suma de estos pequeños todos forma la comunidad. Del mismo modo, para Bentham la felicidad de la comunidad no puede estar relacionada con un bien apartado de los individuos, sino que debe ser una simple suma de las felicidades individuales. Cuanto mayor la suma, mayor la felicidad de la comunidad. El "interés" de la comunidad es la realización de la mayor felicidad que esa comunidad puede alcanzar. Vale decir, la mayor suma posible de felicidades individuales.

(Araujo, C., 2003, p.275).

\section{h) Efecto producido por un encierro largo}

Las penas largas eliminan la esperanza. En el programa implementado para las adolescentes en el Centro Juvenil de Diagnóstico y Rehabilitación de Lima (Maranga) se sigue el siguiente esquema:

El primer contacto de los jóvenes en el medio cerrado incluye la convivencia en condiciones muy precarias: Programa I, todos los jóvenes están alojados en un solo ambiente, con camas simples, una pequeña división de 10 metros cuadrados con una mesa rectangular que sirve para tomar los alimentos, ínfimos baños comunitarios; además tiene otro pequeño ambiente que consiste en una habitación de 10 metros cuadrados, los jóvenes van sentados en el piso esperando por el baño. No se tiene ningún taller de aprendizaje, es solo una etapa de "bienvenida" que dura en promedio un mes, se enseñan las reglas básicas de la institución. En el Programa II, las condiciones relativas al espacio mejoran, no obstante, los servicios higiénicos son ínfimos, 6 u 8 baños para 180 personas en promedio. Aquel programa sí desarrolla talleres educativos y también se implementan programas de estudio escolar. Como distracción se tiene una pared amarilla y 4 raquetas de frontón. En el Programa III, es muy similar al programa anterior, no obstante, se supone que la comodidad debe ser notoria y con atenciones más cordiales. Finalmente, el Programa IV utiliza camas unitarias, no camarotes, cajones de madera, buena infraestructura, televisión, baños y duchas cómodas que solo comparten con 12 personas.

La suspensión del trabajo no representa, por sí misma, más que una idea negativa; pero cuando se considera la condición de quien, después del trabajo físico, se dedica al reposo, se verá que el placer es una cantidad positiva; pues en este caso se experimenta, no simplemente una cesación de malestar, sino una sensación agradable de naturaleza particular, tal que, sin el antecedente del trabajo, no se hubiera realizado. (...) Considerada en sí misma, una ocupación puede ser dolorosa, placentera o indiferente; pero si se continúa más allá de cierto tiempo y sin interrupción (así es la naturaleza humana) toda ocupación, cualquiera que sea, se hace desagradable; y no solamente 
ocurre así, sino que las que eran agradables en un principio, por su continuación se convierten en más desagradables que las que eran, originalmente, indiferentes.

(Bentham, J., 1965, pp.23-24).

Los jóvenes castigados con 4 o más años, sienten la desesperación de la repetición constante de estos programas, el efecto descrito -líneas arriba por Bentham- se cristaliza y ocasiona depresión, violencia, pérdida en el sentido del Programa resocializador, hastío, y desesperación por seguir en un lugar donde es muy difícil conseguir y conservar condiciones dignas.

Indefectiblemente, por la duración de sus castigos cometerán algún acto impulsado por el estrés: Tensión provocada por situaciones agobiantes que originan reacciones psicosomáticas o trastornos psicológicos a veces graves (RAE, 2018). Los jóvenes infractores, conscientes que cumplieron el programa con éxito, observan a los días avanzar y su juventud también, sus seres queridos están muy lejos, no obstante, deben seguir muchos años más en un medio cerrado.

Ese pensamiento genera un desprecio por la sociedad, rechazo a la repetición de los Programas y las conllevará a un nuevo entorno de agresividad reiterativa y cíclica. Recordemos, son adolescentes que aún mantienen el córtex prefrontal del cerebro en formación, las inhibiciones están en proceso de asimilación. En adición, es necesario reflexionar si: "Específicamente las sanciones no monetarias deben emplearse sólo donde las monetarias no puedan detener adecuadamente actos indeseables. (...) las sanciones no monetarias deberían emplearse sólo después que haya sido impuesta una sanción monetaria igual a la riqueza de una de las partes" (Shavell, S. 2000, p.440).

\section{i) Informalidad (el costo de la legalidad)}

La informalidad genera desorden, caos y acarrea de manera tácita actos delictivos. Las pérdidas que genera la actividad informal son soportadas por el grueso de la sociedad, evita la mejora en los servicios básicos y frena el camino hacia la modernización; pese a ello, muchas personas, orgullosas, la celebran. Esta enfermedad social refuerza la disfuncionalidad del Estado y también debilita los valores de la nación. Por tanto, es menester brindar una mirada a los principales conceptos y orígenes de este problema.

Enfocados en las necesidades del mercado observamos una tendencia constante: El mercado con un enfoque sobre proteccionista exige a empresas en la primera etapa de "nacimiento" costos desmedidos, que resultan muy difíciles de conseguir pese al trabajo duro y constante. La balanza se inclina a favor de los costos y los beneficios quedan olvidados. 
En adición, el Estado muy pendiente e interesado en los consumidores impone grandes multas, sanciones y garantías a aquellos nuevos emprendedores que deben de pagar un crédito, planillas, alquileres, impuestos, etc. Somos un país muy pobre, que sin embargo, mantiene las exigencias administrativas de un país rico (Ghersi, E., s.f.). Esta característica genera trabas en el desarrollo mercantil, y de sobre manera, ocasiona informalidad.

El propósito económico fundamental del derecho es reducir los costos de transacción, pero la ley también tiene un costo, que el autor denomina "costo de la legalidad". El estudio de la informalidad muestra cómo el costo de la legalidad, cuando es muy alto, conduce a la desobediencia civil. La deformación del ideal democrático ha popularizado la creencia de que todo acto legislativo se hace ley, sin considerar si se ajusta al derecho y al orden moral vigentes. Esta ilusión conduce a que la ley quede neutralizada por su propio costo de realización.

(Ghersi, E., s.f., p.1).

Las personas preferimos mantener los beneficios por encima de nuestros costos, en todo momento, y si existen disposiciones que generen un escenario inverso, se hará todo lo posible por mantener un beneficio constante y superior a las obligaciones.

Así también, las sanciones elevadas y acumulativas, en lugar de causar un efecto disuasorio, acarrean incumplimiento, impunidad; corrupción. El consumidor promedio que estaciona en una zona prohibida prefiere pagar 20 soles a un policía de tránsito que cumplir con una multa de 3, 000.00 soles; a todas luces, pagar esa multa significaría la descapitalización y peligro de quiebra, más aún en el Perú, donde la remuneración mínima vital no supera los 900.00 soles. Las personas que trasgreden las normas más simples sienten orgullo, equivocados hablan de ello, apologizan y contagian conductas carentes de moral, la cooperación y solidaridad ya no resultan visibles. Creamos informalidad. El costo de la legalidad en el Perú no es un tema nuevo, fue bastante desarrollado por Enrique Ghersi y Mario Ghibellini en El otro sendero de Hernando de Soto (1986).

En un país pobre y en vías de desarrollo, incrementamos los costos de una empresa recién inscrita, con el buen propósito de prevenir; sin embargo, olvidamos que estos grandes costos no se pueden afrontar desde el momento de la creación de la empresa. Un diferente escenario se configura luego de lograr ingresos, tiempo de permanencia en el mercado y atendiendo al manejo de conceptos como repartición o distribución de costos y riesgos. En ese instante, sí es posible cumplir con todas las formalidades y especificaciones impuestas. 
"Por último, nunca debe olvidarse que es más útil prevenir los delitos que decretar las penas, y el mejor método de prevención es la reforma educativa" (Pietro Sanchís, 2007, p.160). Estos factores de riesgo merecen una atención constante y preferente, las buenas prácticas que se desarrollen en torno a ellas representan también un ahorro importante de patrimonio. La informalidad se enraíza en los casos habituales y se asienta en la cultura popular y por tanto se transmite al futuro.

Existen otros factores de riesgo, no obstante, ninguno de ellos es determinante para llevar al adolescente a cometer una infracción penal:

$\mathrm{Al}$ respecto, se ha podido corroborar que existen factores asociados a la procedencia de hogares desestructurados, la deserción o fracaso escolar, el consumo de drogas y alcohol, y el vínculo pernicioso con pares. Ninguno de estos factores determina por si solo el que se vaya a cometer una infracción a la ley penal. Es la presencia de varios de estos y la trayectoria personal de cada adolescente las que lo harán.

(Consejo Nacional de Política Criminal, 2014, p.68).

Figura 1.2.

Perspectivas de prevención, administración de Justicia, resocialización y de tratamiento de víctima

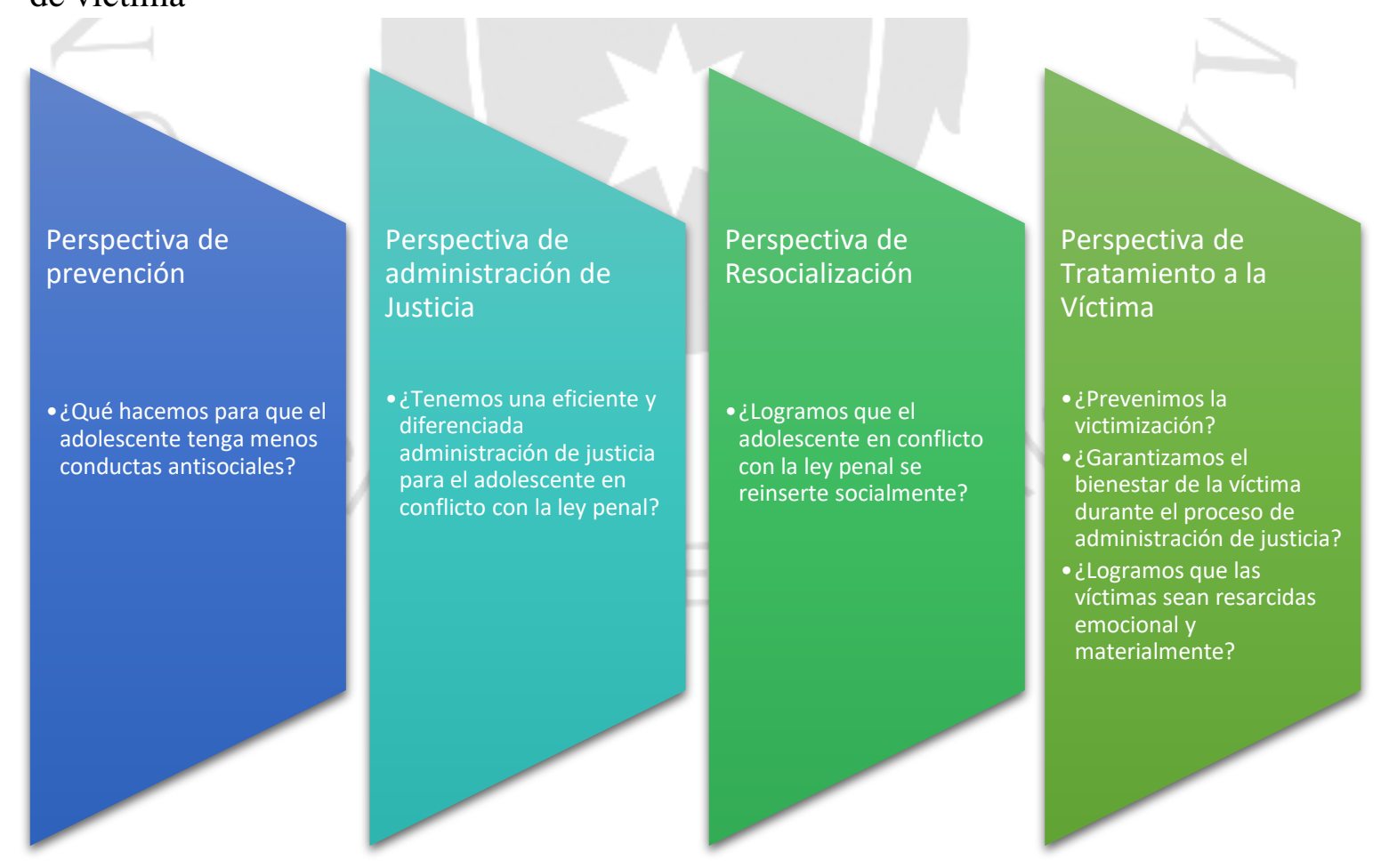

Nota: Incluye a los principales actores de un hecho delictivo. 
Fuente: Consejo Nacional de Política Criminal. (2014). Plan Nacional De Prevención Y Tratamiento Del Adolescente En Conflicto Con La Ley Penal 2013-2018. Lima: Grupo Raso E.I.R.L. Pág. 48.

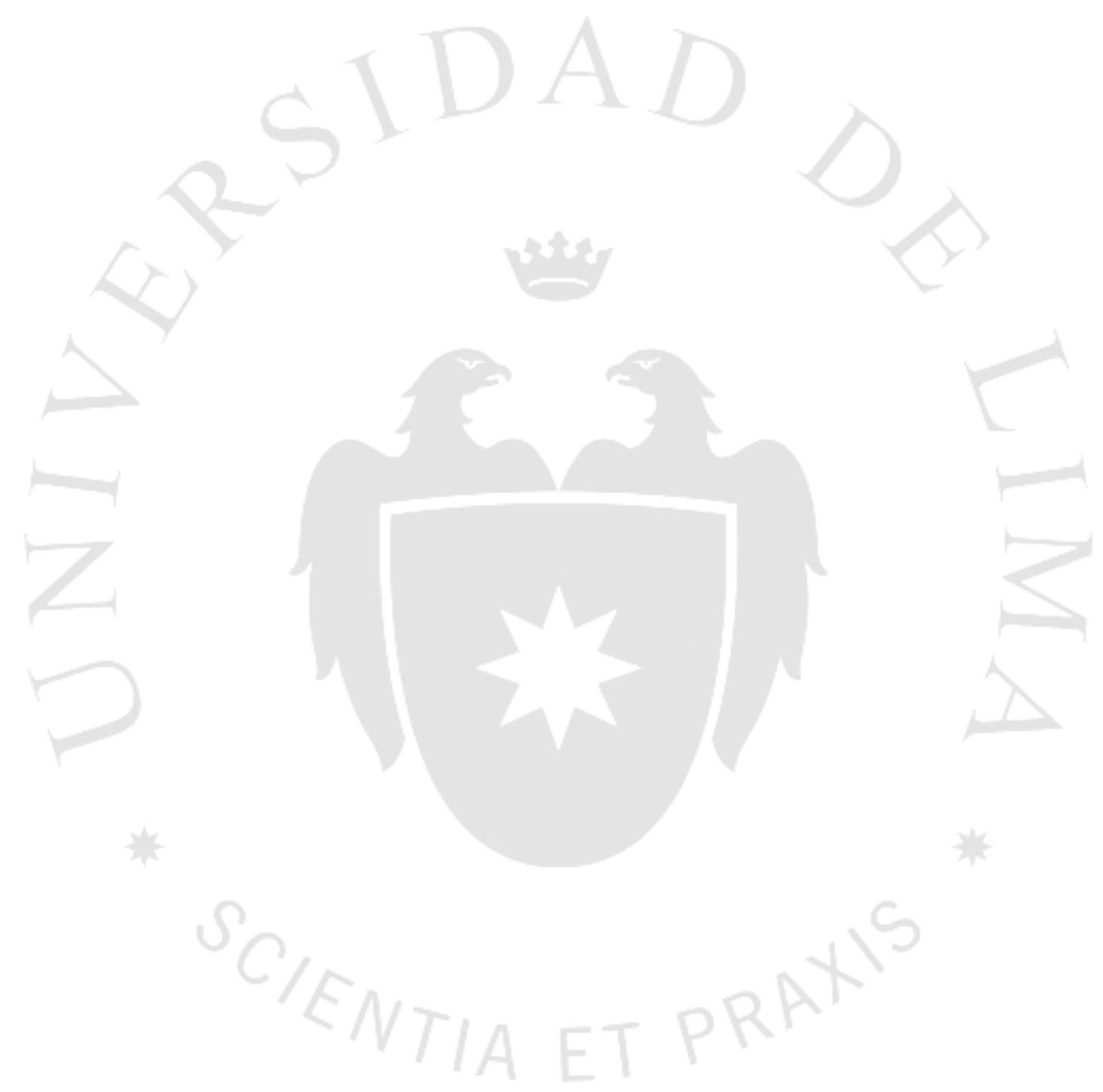




\section{CAPÍTULO II: ALGUNAS RAZONES Y CONSECUENCIAS DEL ENCIERRO}

\section{1.- Estado de la situación}

Existen diversos problemas que atañen a la administración de Centros Juveniles para adolescentes infractores, que serán desarrollados en diferentes niveles, ya que no todos poseen la misma relevancia, ni impacto directo con la investigación. El listado realizado pretende englobar las primeras causas de su ineficiencia, para luego examinar los efectos de estas falencias; todo ello con la finalidad de determinar si la propuesta de la presente tesis, mitiga estos efectos nocivos para nuestra seguridad y el desarrollo en un contexto de libertad para la colectividad.

\section{2.- Justificaciones estatales frente al estado de la situación}

\section{a) Falta de recursos: excusa del ámbito administrativo}

Una de las principales falencias en el sistema de reinserción social es atribuida a la poca disponibilidad de recursos económicos. Los centros de medio cerrado para menores infractores tienen distintos gastos; así, estás los de contratación laboral (Personal Administrativo y Logístico, Educadores Sociales, Trabajadores Sociales, Psicólogos, Médicos, Agentes de Seguridad, etc.), este rubro representa el porcentaje mayoritario de recursos empleados; el gasto restante es distribuido entre las necesidades básicas de los menores (alimentos, Seguro Integral de Salud, uniformes, útiles de aseo, etc.), finalmente el monto que queda se dirige a cubrir los gastos que se realizan en los diferentes talleres (materiales, utensilios, herramientas, etc.)

Por otro lado, el gasto que pueda realizar el Estado para un mejor tratamiento de los jóvenes que han infringido la norma penal debe ser visto como una inversión que coadyuve a mejorar los niveles de inseguridad ciudadana, lo cual permitirá que conforme pase el tiempo sean menos los adolescentes dispuestos a una precoz incursión en una carrera criminal.

(Beatriz M, 2007).

Del mismo modo es necesario contemplar otros gastos, tales como los traslados de los adolescentes al interior del Perú -pese a que las video conferencias fueron instauradas para evitar ese gasto, aún resulta necesario trasladar a los menores de Lima a distintas provincias-, además es necesario en muchos de los casos realizar diligencias de reconstrucción, hay gastos específicos en estos desplazamientos y viajes, como la alimentación comida para el adolescente, y sus dos 
custodios o educadores sociales, además del policía que los cuida; asimismo, este presupuesto debe cubrir las enfermedades de los menores. En el caso del Centro Juvenil de Diagnóstico y Rehabilitación Santa Margarita, las jóvenes mujeres internas, deben ser atendidas cuando se encuentran en periodo de gestación, el tratamiento, alimentación, pañales y demás necesidades básicas de los hijos que permanecerán hasta los 3 años de edad.

Del mismo modo, se debe atender el mantenimiento de todos los establecimientos dedicados a esta labor ${ }^{4}$, destinado a pintura, adecuación y limpieza de los servicios higiénicos, atención del costo de la energía eléctrica, el agua, teléfono e internet para toda la logística administrativa. Otras adquisiciones como ropa deportiva, frazadas, cochones, camarotes, etc., que deben cubrirse con el mismo fondo.

En consecuencia, los recursos asignados cumplen la función básica de cubrir las situaciones elementales y necesarias para que estos centros puedan continuar. Sin embargo, se olvidan del propósito fundamental de estos centros, que debería enfocarse en las medidas necesarias y mecanismos para lograr una exitosa reinserción. El mayor porcentaje debería estar destinado a talleres y sistemas de reinserción social, es decir, se debe gastar en instruir a los menores, crearles habilidades que destaquen en los tiempos en los que vivimos ${ }^{5}$. Por ello, estos escasos recursos deben ser invertidos en educar a los menores hacia oficios mejor remunerados, y también celebrar convenios que garanticen un lugar de colocación donde estos menores puedan trabajar luego de cumplir con su medida socio educativa, puesto que de lo contrario seguirán conviviendo con el medio que en gran medida causó su conducta infractora. Estas características permiten afirmar que estos centros juveniles mantienen una política de contención, más que de reinserción efectiva.

\footnotetext{
${ }^{4}$ Verbigracias Centro Juvenil de Diagnóstico y Rehabilitación de Lima conocido por Maranguita ya cuenta con 70 años de antigüedad. La cercanía con el mar y el adusto clima de nuestra ciudad ocasiona que la construcción se encuentre muy deteriorada. Fallas constantes se han presentado en el sistema de desagüe y cañerías. Los pocos baños que se emplean en los patios sufren constantes fallas y clausuras extendidas.

${ }^{5}$ Un taller de Bisutería resulta desfasado e ineficiente, pues la ganancia que representa este trabajo es ínfimo, este trabajo arduo y de mucha dedicación con la utilización de materiales conlleva una ganancia que muchas veces solo cubre los costos; los menores emprendedores que desarrollan este oficio olvidan, dentro de su planteamiento de negocio, conceptos básicos como son "las horas hombre" y "el punto de equilibrio". En ese sentido, el Psicólogo Arequipeño Javier Cori que trabajó en el Centro Alfonso Ugarte de Arequipa, está convencido que estos oficios que aprenden los menores son desfasados y no se pueden obtener muchas ganancias con ellos, propone que se deben enseñar oficios actuales y acordes a nuestro contexto de desarrollo, aprendizajes relacionados con la Ingeniería de Sistemas y Minería.
} 


\section{b) El contexto de pobreza que contagia y agudiza la delincuencia o la infracción (Julián, el cholón)}

El tema migratorio, los embarazos no deseados, el trabajo/explotación juvenil, entre muchos otros factores han creado una serie de factores que dañan el sistema de seguridad, pues este contexto en alguna medida gesta criminales juveniles, debido a que a edad muy temprana los menores resultan abandonados o son expuestos a situaciones donde tienen que afrontar responsabilidades para las cuales, por su edad, no están preparados.

Un ejemplo real fue recogido en una de las crónicas de Luis Urteaga Cabrera (2014) en su excelente libro Los Hijos del Orden, producto de varias entrevistas que se llevaron a cabo en el Centro Juvenil de Diagnóstico y Rehabilitación de Lima (en adelante Maranga o Maranguita) en los años 60. En él, este investigador cuenta la historia de Julián (alias Cholón), que llegó a la ciudad de Lima en un camión que transportaba papas desde algún pueblo olvidado de los andes.

Este menor con solo 6 años de edad llegaba con el propósito de encontrarse con su padre y por algún tiempo vivieron juntos en una construcción donde el señor trabajaba de cuidante; para Julián elaboraron una cajita de lustra botas, con esa herramienta el niño de 6 años trabajaba por un sol cada vez que alguien deseaba limpiar sus zapatos. Uno de los picos más altos de la historia sucede cuando el padre de Julián decide ir a conseguir un lugar donde vivir, se agruparon con muchas personas que deseaban lo mismo y tomaron posesión de un basural a la ribera del río Rimac; lamentablemente el señor invasor fue detenido y el niño Julián se quedó entre las esteras de un río, junto a un basural con muchas personas a quienes no conocía ni se conocían entre sí.

Al mucho tiempo de necesidad, la madre y hermana del menor llegaron también en un camión desde su pueblo de la sierra de nuestro país, y una noche de crecida, el río entró a las esteras, se llevó el triplay que cumplía la función de pared, las mesas de plástico y la cajita de lustra botas de Julián. Esa noche las personas que vivían junto al río estuvieron sumergidas en agua helada y la hermana de este menor se enfermó. Sin dinero y con la necesidad apremiante de la enfermedad de su hermana menor, Julián decide pedir ayuda a uno de los jóvenes que se dedicaba a conseguir dinero de manera ilícita. Este relato termina con la adaptación del menor en la vida criminal.

Un entorno de necesidad apremiante requiere respuestas inmediatas, y muchas de ellas no suelen ser legítimas ni ordenadas. Nuestro país -aún en vía de desarrollo- mantiene todavía en gran medida el desorden y los valores son motivo de burlas y rubores. La mayoría de los peruanos consideran que esta realidad amoral solo existe en los sectores menos favorecidos (económica y 
culturalmente) (Gestión, 2014); sin embargo, hasta en el sector industrial y profesional también encontramos crímenes, denominados Delitos de Cuello Blanco (White Collar Crime).

Aquel menor descrito en la crónica de Urteaga se amoldó a su contingencia, adaptando sus necesidades al sistema, y quizás pudo pensar que era una salida momentánea u extraordinaria. Sin embargo, como la mayoría de nosotros, nos hemos acostumbrado a nuestro oficio de emergencia, nos desarrollamos en él y nos convertimos en especialistas; dejamos en suspenso indeterminado nuestro objetivo original.

En consecuencia, los criminales juveniles no nacen convertidos en grandes asesinos, la violencia con la que tienen que lidiar y las necesidades a muchos los llevan a perder la empatía por las demás personas.

\section{c) Hacinamiento y consecuencias de seguir con el mismo modelo. Una mirada a Brasil y al futuro}

El hacinamiento para el año 2017 en los diferentes Centros Juveniles del Perú evidencia que el medio cerrado no puede actuar con eficiencia, toda vez que contamos con un porcentaje de sobrepoblación del $52.67 \%$ a nivel nacional. Bajo esta observación es posible deducir que la rehabilitación ha quedado sustituida por la contención. 
Tabla 2.1.

Capacidad de albergue y sobrepoblación

\begin{tabular}{|c|c|c|c|c|c|}
\hline \multicolumn{7}{|c|}{ CAPACIDAD DE ALBERGUE Y SOBREPOBLACIÓN } \\
\hline$N^{\circ}$ & CENTRO JUVENIL & $\begin{array}{c}\text { CAPACIDAD DE } \\
\text { ALBERGUE } \\
(\mathbf{C A})\end{array}$ & $\begin{array}{c}\text { POBLACIÓN } \\
\text { EXISTENTE } \\
(\text { PE) }(*)\end{array}$ & $\begin{array}{c}\text { ÍNDICE DE } \\
\text { ATENCIÓN } \\
(\%)\end{array}$ & $\begin{array}{c}\text { PORCENTAJE DE } \\
\text { SOBREPOBLACIÓN }\end{array}$ \\
\hline 1 & CJDR Lima - Lima & 560 & 957 & $170.90 \%$ & $71.00 \%$ \\
\hline 2 & CJDR Santa Margarita - Lima & 88 & 97 & $110.20 \%$ & $10.00 \%$ \\
\hline 3 & CJDR Alfonso Ugarte - Arequipa & 92 & 131 & $142.40 \%$ & $42.00 \%$ \\
\hline 4 & CJDR José Quiñones Gonzales - & 126 & 181 & $143.70 \%$ & $44.00 \%$ \\
\hline 5 & CJDR Marcavalle - Cusco & 96 & 183 & $190.60 \%$ & $91.00 \%$ \\
\hline 6 & CJDR E1 Tambo - Huancayo & 110 & 147 & $133.60 \%$ & $34.00 \%$ \\
\hline 7 & CJDR Miguel Grau - Piura & 185 & 154 & $83.20 \%$ & $0.00 \%$ \\
\hline 8 & CJDR Pucallpa - Pucallpa & 110 & 217 & $197.30 \%$ & $97.00 \%$ \\
\hline 9 & CJDR Trujillo - Trujillo & 106 & 196 & $184.90 \%$ & $85.00 \%$ \\
\hline & TOTAL NACIONAL & $\mathbf{1 4 7 3}$ & $\mathbf{2 2 6 3}$ & $\mathbf{1 5 0 . 7 6 \%}$ & $\mathbf{5 2 . 6 7 \%}$ \\
\hline
\end{tabular}

Nota: la capacidad máxima de albergue es de 1473 menores, no obstante, la población existente es de 2263 adolescentes infractores. Ello acarrea una sobrepoblación general de 52.67\%. Fuente: Poder Judicial. (2017). Informe estadístico 2017.

Fuente: Elaborado por: Oficina de Imagen Institucional. Gerencia de Centros Juveniles. Pág. 8. Recuperado de: https://www.pj.gob.pe/wps/wcm/connect/1f406f004130447dae92febfe240fdac/Estad\%C3\%ADstica+Web++Febrero+2017.pdf?MOD=AJPERES\&CACHEID=1f406f004130447dae92febfe240fdac

Además, es posible afirmar que todos los programas que se desarrollaron en el año 2015 en la administración de Centros Juveniles de Lima fue ineficiente; ya que en existió hacinamiento en cada uno de sus ambientes. Ello supone menos recursos empleados, variación en la estrategia educativa y resocializadora, déficit en el control y cuidado de los jóvenes adolescentes. "Del presente análisis se deduce que el sistema penitenciario es, en su conjunto, contrario a la reinserción del detenido y que su verdadera función es la de constituir y mantener una determinada forma de marginación" (Baratta, 2004, p.198). 
Tabla 2.2.

Población de adolescentes infractores del Centro Juvenil de Diagnóstico y Rehabilitación de Lima por Programas y Ambientes (medio cerrado).

\begin{tabular}{|c|c|c|c|c|}
\hline \multicolumn{5}{|c|}{$\begin{array}{l}\text { POBLACIÓN DE ADOLESCENTES INFRACTORES DEL CENTRO JUVENIL DE DIAGNÓSTICO Y } \\
\text { REHABILITACIÓN DE LIMA POR PROGRAMAS Y AMBIENTES (MEDIO CERRADO) }\end{array}$} \\
\hline PROGRAMAS & AMBIENTES & $\begin{array}{l}\text { CAPACIDAD } \\
\text { INSTALADA }\end{array}$ & \begin{tabular}{|c|} 
POBLACIÓN AL \\
30 DE MARZO DE \\
2015 \\
\end{tabular} & $\begin{array}{l}\text { ÍNDICE DE } \\
\text { ATENCIÓN \% }\end{array}$ \\
\hline Programa I & Bienvenida & 40 & 64 & $160.00 \%$ \\
\hline \multirow{3}{*}{ Programa II } & San Martín de Porras & 100 & 150 & $150.00 \%$ \\
\hline & Nazareno & 60 & 112 & $187.00 \%$ \\
\hline & Domingo Savio & 60 & 107 & $178.00 \%$ \\
\hline \multirow{2}{*}{ Programa III } & Mahatma Gandhi & 100 & 129 & $129.00 \%$ \\
\hline & San Francisco de Asís & 120 & 154 & $128.00 \%$ \\
\hline Programa IV & Don Bosco & 40 & 41 & $103.00 \%$ \\
\hline PII (38 + Ancón 45) & & 40 & 83 & $208.00 \%$ \\
\hline TOTAL & & 560 & 840 & $150.00 \%$ \\
\hline
\end{tabular}

Nota: Para el año 2015 cada uno de los Programas empleados para la resocialización de menores se encontraba con un elevado porcentaje de sobrepoblación (150\%).

Fuente: Estadística interna de la Administración de los Centros Juveniles. (2015). Población de adolescentes infractores del Centro Juvenil de Diagnóstico y Rehabilitación de Lima por Programas y Ambientes (medio cerrado). Documento privado facilitado por la Administración de los Centros Juveniles.

En otro orden de ideas, en Brasil la ONG internacional Human Rights Watch elaboró en octubre del año 2015 un reporte (Muñoz Acebes, 2015) sobre la realidad de las cárceles en Brasil. Se dedujo que el hacinamiento en aquel país, causó (dentro de las cárceles) la propagación del crimen, la impunidad y el contagio de enfermedades graves como la tuberculosis, el VIH-SIDA y diversas afecciones de la piel. En atención a ello, el año 2014 la Corte Interamericana de Derechos Humanos (Human Rights Watch, 2015) ordenó a este país combatir esos graves problemas.

Existe una lógica perversa que tiende un manto entre la sociedad y el sistema carcelario, y esa distancia se traduce inequívocamente, en impunidad y corrupción. Yo mismo, antes de esa experiencia, escuché en la radio que unos presos se quejaban de la mala comida y pensé que era bueno que sufrieran; vamos, que esa era la idea: infringir un castigo doloroso que supusiera sufrimiento. La verdad es lo contrario: frente al instinto pedestre e irreflexivo de una venganza equilibradora, el sufrimiento carcelario se traduce en un rencor que será irremediablemente vertido, a su tiempo, contra la sociedad que paga -con sus impuestos- este proceso.

(Maldonado Manzanilla, 2010, p.81).

Gracias a la orden dictada, se está implementando una medida que permite a los procesados no pasar tiempo en la cárcel o en su caso en el centro juvenil hasta que los Jueces emitan la decisión 
final de su culpabilidad y reclusión ${ }^{6}$. En la cárcel de Pernambuco el 60 por ciento de los 3,200 internos sin condena, están a la espera de su juicio a su sentencia final. Es decir, mientras se decide y se investiga si una persona es el autor de un crimen, ese presunto criminal es víctima de múltiples delitos, que van desde las lesiones leves y graves, los robos y extorsiones, hasta la violación en grupo y el asesinato.

Este problema tomó proporciones mayores cuando los encargados de la seguridad y administración de las cárceles entregaron las llaves de los pabellones a los reos con mayor peligrosidad. Son llamados "llaveros"7 y administraban los espacios para dormir, manteniendo para ellos un lugar privilegiado y cobrando por alquilar los espacios para dormir ("barracos" o cubículos). No existen camas, muchos de los internos duermen junto a las letrinas (6 por cada 60 personas); asimismo, se establecen turnos para que algunos puedan dormir, mientras lo demás se mantienen en pie para crear el espacio suficiente.

A finales del año 2015, la BBC, reportó un explícito caso de asesinato en una de las cárceles de ese país, aquella investigación mantiene datos impactantes “...El número de presos en el país creció 575\% en los últimos 25 años (1990-2014), según cifras del DEPEN, un órgano vinculado al ministerio brasileño de Justicia... 607,731 detenidos, pero sus prisiones tienen capacidad para cerca de 377.000 reclusos. Es decir, la tasa de ocupación llegó al 161\%...” (Lissardy, 2015). Estos análisis ponen a contraluz nuestro presente, el hacinamiento existe en nuestro País.

No solo es la sociedad la que está creando criminales, sino más bien, nuestro sistema reclusorio; los Centros de Diagnóstico y Rehabilitación para menores y las cárceles hacinadas de Lima y Provincias.

En consecuencia, resulta necesario un estudio profundo sobre los efectos y las consecuencias de nuestro sistema resocializador.

\section{d) Efecto "Escuela del mal" (Contacto diferencial)}

Los defensores de esta teoría son Sutherland y Cressy (Cullen, Agnew, Wilcox, 2014), antes de ellos el crimen era explicado desde el sujeto criminal (raza, hogares destruidos, clase social, edad,

\footnotetext{
${ }^{6}$ Una de las medidas destacadas es el inicio de "audiencias de custodia" en todos los estados, que permiten a los jueces determinar qué acusados pueden aguardar su juicio en libertad en lugar de permanecer encerrados, como era habitual hasta ahora.

7 "Chaveiros" o "Keyholders".
} 
daño mental) y no en base a la sociedad. Esta teoría, explica que el comportamiento criminal es aprendido, producto de la interacción (grupo más cercano).

Esta teoría explica que el Contacto Diferencial es un proceso mediante el cual las personas aprendemos conductas criminales de otras. En ese sentido, los medios cerrados de internamiento son propicios para que distintos factores de riesgo coexistan en un solo ambiente, ello ocasiona la asociación -necesaria- entre los adolescentes, lo que produce un contexto favorable para la actividad criminal.

(...), es el de la "culturización" o "prisionalización". En este caso se asumen las actitudes, los modelos de comportamiento y los valores característicos de la subcultura carcelaria. Estos aspectos de la subcultura carcelaria, cuya interiorización es inversamente proporcional a las chances de reinserción en la sociedad libre, se han examinado desde el punto de vista de las relaciones sociales y de poder, de las normas, de los valores, de las actitudes que presiden estas relaciones, así como también desde el punto de vista de las relaciones entre detenidos y el personal de la institución penal. Bajo este doble orden de relaciones, el efecto negativo de la "prisionalización" frente a cada tipo de reinserción del condenado se ha reconocido hacia dos procesos característicos: la educación para ser criminal y la educación para ser un buen detenido. Sobre el primer proceso influye particularmente el hecho de que la jerarquía y la organización informal de la comunidad está dominada por una minoría restringida de criminales con fuerte orientación asocial, que, por el poder $\mathrm{y}$, por tanto, por el prestigio de que gozan, asumen la función de modelos para los otros y pasan a ser al mismo tiempo una autoridad con la cual el personal del centro carcelario se ve constreñido a compartir el propio poder normativo de hecho.

(Baratta, 2004, p.195).

Esta teoría criminológica establece 9 conceptos determinantes para la actividad delictiva (Cullen, Agnew, Wilcox, 2014):

1.- El comportamiento criminal es aprendido: no se hereda, persona necesita entrenamiento, la persona criminal no inventa el delito.

2.- El comportamiento criminal es aprendido en la interacción con otras personas en un Proceso de Comunicación: oral, gestual y de posturas (tatuajes con mensajes subliminales).

3.- Mayor incidencia en el aprendizaje es producto de las relaciones de interacción con las personas más cercanas a nosotros (familia, amigos). No se aprende de los periódicos o libros. Por ello, el papel preponderante en esta característica es dada por el respeto reverencial que se tiene por un miembro de la familia.

4.- Es aprendido: con técnicas para cometer delitos, complicadas y simples. Con motivos específicos (móviles, razones). 
5.- Dirección de motivos: Favorable o no favorable, el grupo define sus propias reglas, distintas a las impuestas por la colectividad (o grupo de poder).

6.- Persona se convierte porque encuentra un exceso de beneficios en la actividad criminal, frente a escasos costos (baja certeza de punición). Resulta inevitable no asimilar la cultura que nos rodea. 7.- El contacto diferencial puede variar según la frecuencia, duración, prioridad e intensidad.

8.- Los patrones del proceso de aprendizaje envuelven todos los mecanismos que están presentes en cualquier otro aprendizaje. No por la simple imitación, sino por un proceso que implica asociación.

9.- No es posible explicar esta teoría desde las necesidades y valores porque las personas no criminales mantienen las mismas necesidades y valores. Por lo consiguiente las asociaciones de las personas están determinadas en general, por la organización del contacto social.

Las cárceles son universidades del crimen" repite el lugar común, pero, en realidad, son grandes congresos, pues permiten una reunión efectiva de miles de personas que delinquen, y lo normal es que se intercambien todo tipo de recetas para ello al tiempo que se reclutan elementos, pues el hampa mexicana existe una estratificación muy estricta y puntual una clara aspiración de los que ocupan menores rangos de llegar a delinquir en las ligas mayores, habida cuenta de lo ya referido en cuanto al carácter ambicioso, decidido y valiente de los ladrones. En esta idea, todos, dentro de un reclusorio, están buscando ser reclutados para ascender y llegar a dar un "gran golpe". Eso motiva un constante e intenso intercambio de experiencias (que se traducen en relatos casi surreales que no tengo espacio para referir aquí) y que hacen que las pláticas seas entretenidas y estremecedoras: el ingenio humano desplegado sin cortapisas resulta siempre un espectáculo. (Maldonado Manzanilla, 2010, pp.80-81).

\section{e) La eficiencia del sistema reclusorio peruano}

La finalidad del castigo en el sistema de encierro está circundada por el concepto denominado peligrosidad, elemento que facilita y prejuzga una acción futura en la persona (sin certeza) y que obliga a los controles sociales formales a adelantar su función restrictiva de conductas.

(...), pueden resumirse en el hecho de que los centros de detención ejercen efectos contrarios a la reeducación y a la reinserción del condenado, y favorables a su estable integración en la población criminal. La cárcel es contraria a todo moderno ideal educativo, porque éste estimula la individualidad, el autorrespeto del individuo, alimentado por el respeto que le profesa el educador. Las ceremonias de degradación al comienzo de la detención, con las cuales se despoja al encarcelado hasta de los símbolos exteriores de la propia autonomía (la vestimenta y los objetos personales), constituyen lo opuesto a todo eso. La educación alienta el sentimiento de libertad y de espontaneidad del individuo; la vida en la cárcel, como universo disciplinario, tiene un carácter represivo y uniformante.

(Baratta, 2004, p.194). 
El Derecho penal debe utilizar sus principios para la aplicación y ejercicio de toda su acción controladora; es decir, exigir el razonable ejercicio del ius puniendi en el poder público. Con ello, es posible reducir vulneraciones a los derechos fundamentales de la persona, y limitar la exigencia en el cumplimiento de las conductas permitidas.

Por otra parte, sólo hace falta imaginarse un Derecho penal sin parte general, para darse cuenta de que la renuncia a una teoría del delito, tanto generalizadora como diferenciadora, en favor de una cualquiera "valoración" individual haría retroceder a nuestra ciencia varios siglos, a aquella situación de "acaso" y "arbitrariedad", de la que desde los tiempos de Liszt se abjura con razón por todos los apologetas del sistema. Puesto que no parece seriamente discutible la posibilidad de un abandono del sistema, pero las objeciones que se han hecho valer anteriormente sigue vigentes, es natural que deben achacarse no al pensamiento sistemático como tal, sino al equivocado planteamiento de su desarrollo dogmático.

(Roxin, 2000, pp.41-42).

De ese modo, cuando los principios impregnados en el Derecho Penal (con función garantista y razonable) no son aplicados, sucede una desproporción en el castigo, sin garantías y con una rapidez y adelanto en la función punitiva.

(...), dicha tendencia sí ha tenido un impacto de carácter negativo en el SRSALP -Sistema de Resocialización para Adolescentes en Conflicto con la Ley Penal- evidenciándose en la sobrepoblación, mayor permanencia dentro de los centros juveniles, déficit en el tratamiento, y el intercambio de vivencias con grupos etarios diferentes (mayores), así como la no existencia de programas educativos especializados para estos últimos.

(Consejo Nacional de Política Criminal, 2014, p.72).

Estudios en la región han mostrado los efectos negativos que genera el internamiento como regla general en los adolescentes en conflicto con la ley penal. Entre ellos, se ha identificado que los procesos cognitivos se empobrecen por falta de estímulos y, en muchos casos, se retrocede y pierden habilidades previas; el encierro es fuente de descompensaciones patológicas previas e, incluso, del desarrollo de patologías psiquiátricas severas; los vínculos sociales no solo se rompen en muchos niveles, sino que además, en la mayoría de las ocasiones se vuelven perversos, restringiendo los roles sociales de forma abrupta entre ellos; entre otros.

(Consejo Nacional de Política Criminal, 2014, p.78).

Así también, los efectos posteriores al encierro, como la ruptura de vínculos sentimentales, amicales, familiares, pérdida de oportunidad de estudio y experiencia laboral, acarrean en el sujeto infractor la estabilidad en la actividad criminal. "Debemos reflexionar que ya soporta, o soportará, toda la penalidad de su error; que ella arruine su vida por una conducta equivocada no es razón para que nosotros deseemos extremar más todavía su ruina: en lugar de desear su castigo, debemos 
más bien tratar de aliviárselo mostrándole cómo puede evitar o curar los males que su conducta le acarrea" (Stuart Mill, 2013, p.185).

En ese sentido, resulta menester implementar nuevas opciones de ayuda que mitiguen los efectos del crimen, en ese camino se encuentra la Justicia Restaurativa: “(...), se ha demostrado que las medidas de medio abierto o fuera del sistema de justicia penal no solo son menos costosas para el Estado, sino también mucho más efectivas, habiéndose logrado reducir la reincidencia en mayor proporción, siendo necesario para ello la generación de una oferta de un servicio adecuado" (Consejo Nacional de Política Criminal, 2014, p.78).

"De acuerdo a estudios, se puede apreciar que un adolescente podría soportar una internación de aproximadamente 3 años; sin embargo, según lo señalan los profesionales expertos que se encuentran en contacto directo con los adolescentes, "(existe) involución en los jóvenes después de transcurridos 2 años de privación de libertad y que este fenómeno se intensifica cuando su externamiento no es muy próximo (...). Este resultado fallido de los objetivos de dichos programas se reflejan en el grado de reincidencia y deserción".

(Consejo Nacional de Política Criminal, 2014, pp.90-91).

Aquellas razones, en un contexto de medio cerrado, se suman que no existe un tratamiento diferenciado para los menores infractores; es decir, no se encuentran diferenciados por la infracción cometida; todos los distintos perfiles se encuentran en un mismo patio.

En ese sentido Zaffaroni dentro en su discurso del tratamiento y la realidad penitenciaria (para adultos) expresa que: “(...), la prisión provocaba siempre efectos deteriorantes en los prisioneros y reproducía violencia, del mismo modo en que lo sigue haciendo en la actualidad" (Zaffaroni, 1997, pp.179-191). Al referirse de la historia y el camino de las cárceles señala al Panóptico de Bentham como un instrumento que nunca funcionó y tampoco a las construcciones que la sustituyeron y que las políticas penitenciarias crearon toda clase de problemas "en las prisiones: superpoblación, mayor violencia, carencias elementales, inseguridad, etc. El deterioro de las cárceles y su efecto reproductor más acentuado fueron instrumentados por los reaccionarios más increíbles que aprovecharon para propugnar la necesidad de volver a la prisión de mera seguridad o contención, militarizada en forma de "fortaleza" (Zaffaroni, 1997, p.181).

Uno de los grandes problemas de la administración de justicia penal está determinada por el excesivo uso de la prisión preventiva (en el caso de jóvenes, internamiento preventivo), por 
ejemplo, en el Centro Juvenil para mujeres (Santa Margarita) de la población total en el año 2016 más del $15 \%$ de menores se encuentra sin una sentencia firme ${ }^{8}$.

(...) en la mayoría de nuestros sobrepoblados centros penitenciarios de América Latina y el Caribe, más de $70 \%$ de la población no ha sido sentenciada debido a la lentitud de los procesos judiciales y, por lo tanto, se trata de personas presumiblemente inocentes. En efecto, decenas de miles de personas continuarán languideciendo durante años en nuestras cárceles a la espera de una sentencia condenatoria o absolutoria, cuando no de una orden judicial o ministerial para hacer efectiva la libertad por cumplimiento de la sentencia.

(Tidball-Binz, 2001, p.53).

Elías Carranza, investigador abocado al trabajo en Política Criminal, sociología criminal y sociología del sistema de justicia penal elaboró un análisis titulado "Sobrepoblación Penitenciaria en América Latina y el Caribe: Situación y Respuestas posibles" en el cual se incluye las ideas básicas de la Sra. Vivien Stern, y también de la sentencia de la Sala Constitucional de la Corte Suprema de Justicia de Costa Rica, respectivamente dicen lo siguiente:

(...) quien fue encerrado durante dos años por hurtar un radio de 12 dólares deba ser castigado con el contagio de una enfermedad incurable... Si el Estado, cumpliendo con una función pública como lo es el velar por la seguridad ciudadana, aísla y priva de su libertad a personas que han infringido la ley, debe hacerlo dentro del marco que establece el respeto a los derechos humanos, como se ha comprometido, tarea que en el caso de la custodia de las personas privadas de libertad corresponde al Poder Ejecutivo, siendo la labor del Poder Judicial -y dentro de éste- particularmente el Tribunal Constitucional, velar porque así se cumpla.

(Carranza, 2001, p.34).

\section{f) El abuso del poder como factor situacional (aplicación del análisis de Zimbardo)}

Me sacaron de la casa un domingo por la mañana, es un experimento, lo sabía, pero los vecinos no. Todos salieron con mangueras y el café en las manos. Me recostaron en la puerta de su patrulla y colocaron los grilletes, una de mis muñecas se lastimó, y buscaron metales, puntas entre mi ropa. Cuando me llevaron a Palo Alto, desnudo, sacaron las huellas de mis dedos, y tomaron fotografías; algo que jamás olvidaré: me quitaron el nombre (164 porque la espalda de esa bata tenía ese número). Me llevaron a un sótano de la Universidad de Stanford y toqué la mano a otro muchacho que estaba en la celda conmigo, el aire era fresco pese al encierro. Tomé mi primera siesta y desperté por la bulla en el corredor, sin saber la hora, alcancé a colocarme los lentes y unos brazos me sacaron muy rápido de la celda, me empujaron al piso y había gritos, batas en el suelo y cuerpos

\footnotetext{
${ }^{8}$ Entrevista a la Dirección del Centro Juvenil de Diagnóstico y Rehabilitación para mujeres (Santa Margarita). Población total para setiembre de 2016: 100 personas y más de 15 menores se encontraban sin sentencia firme.
} 
desnudos, mi compañero gritaba desquiciado, pedía ver a un médico, quería salir, se volvería loco si no lo conseguía. Uno de los policías utilizó un extintor para enfriar el ambiente donde retenían al incitador. Estaba helado, desnudo, y para que la enfermedad no contagie nos obligaron a hacer ejercicio, primero planchas, luego corrimos a la ronda en un espacio de 8 metros cuadrados, éramos camellos uno detrás del otro para que los guardias mantengan su cuota de obscenidad. Lo que se suponía tenía que durar dos semanas, sólo fueron 6 días y cada segundo lo recuerdo, las torturas psicológicas, los gritos, aquel piso helado, el olor a óxido y cuero mojado, un estudiante convertido en un huelguista de hambre. Olvidé que se trataba de un experimento, jamás pedí frenarlo, me incluí en el encierro y los policías eran tan imaginativos, fuertes, de gafas y gritos (Vallester, 2013).

Zaffaroni cita a Irwin en el libro The Jail, para decir que Irwin señala cuatro momentos en el proceso de deterioro institucional: desintegración, desorientación, degradación y preparación. Zaffaroni explica que no es intencional la degradación o el deterioro, pues el operador de prisión busca equilibrar y mantener el statu quo de poder interno; en virtud de ello establece que "El deterioro carcelario o prisonización es solo el efecto inevitable de las medidas que deben tomarse para establecer y sostener el statu quo" (Zaffaroni, 1997, p.181).

En todo momento, los criminales que se encuentran en un ambiente de sometimiento e incapacidad, se irán alimentando de los abusos que se cometen. Estos factores crean resentimiento, odio, más violencia y ánimo de venganza; los códigos se extrapolan y el respeto por la sociedad se transforma en la admiración hacia el criminal más exitoso, imaginativo. La Situación determina conductas, decisiones y reacciones.

El Psicólogo norteamericano Philip Zimbardo realizó en el año 1971 un experimento en la Universidad de Stanford, llamado "Maldad por Situación”. Para ello seleccionaron a un grupo de 18 estudiantes de un universo con 75 voluntarios, personas física y mentalmente estables, al azar, sin antecedentes criminales; el propósito era alojarlos por un mes a una instalación que simulaba una cárcel, observar sus comportamientos y establecer una teoría.

Para aquellos fines, el número total de 18 personas fue dividido en dos grupos al azar. En esta cárcel de fantasía 9 serían reclusos y el resto, guardianes o policías. A los primeros se les entregó ropa ligera, muy simple, parecida a las batas que entregan en una clínica; mantenían un número en la espalda (su nueva identidad), además llevaban sandalias. Sin embargo, el grupo que interpretaba a los policías llevaban el uniforme completo: camisa, pantalón, correa, zapatos, medias, calzoncillos y gafas oscuras. 
Este experimento demostró que la situación a la que nos sometemos define nuestro comportamiento; aún más cuando el factor poder es matiz presente del contexto situacional. Se evidenció que, poco a poco, la autoridad "no ganada", fruto de una escena fantasiosa, es tomada muy en serio; los personajes asumen su condición y reaccionan de la manera en que ellos creen "adecuada".

Desde el primer día de iniciado el estudio, se crearon coyunturas muy usuales y comunes que suceden en una prisión: formación de grupos, búsqueda de apoyo en los más influyentes, espacio de aislamiento, separación de personas, castigos y alternativas de control.

Verbigracia, se formaron asociaciones entre el grupo de "reclusos" para evitar abusos y simular control en las situaciones triviales. Las personas que fueron designadas para ejercer el papel de policías intentaron hacer respetar sus atribuciones y de forma casi instantánea fueron abusivos. Sólo fueron suficientes dos días, para que los "prisioneros" se amotinen; a su vez, se cometieron castigos excesivos.

Producto del motín, se utilizaron medidas acostumbradas en un contexto real: racionamiento de alimentos, humillación, activación de un extintor de fuego sobre los cuerpos desnudos (simula el castigo de la ducha con la manguera gigante de agua helada); la imaginación brillaba en el grupo de poder. En los roles desempeñados, de reo y policía, se estableció una dicotomía, corrupta por el poder y la superioridad, donde unos se convierten en sublevados y los restantes en abusadores.

El medio es determinante para que nuestras conductas sean amoldadas, somos seres animados de contexto, y no importa nuestra esencia, pues cuando ésta no se pueda ejercer, seremos lo que el grupo dominante es, lo que el ambiente nos empuja a ser.

Por tanto, dicho experimento evidenció que el medio en el que nos encontremos definirá nuestro comportamiento. Cuando la realidad nos presenta un medio adverso y extremo, reaccionaremos con respuestas de igual naturaleza. No hace falta convertirnos en criminales o policías para desarrollar sus comportamientos, abusos y métodos coercitivos, lo único necesario es el contexto: la situación.

\section{3.- Inocuización y contención vs resocialización}

Parece que el legislador, junto al grupo que ejerce el Control Social formal, mantiene una postura inocuizadora sobre las personas (y adolescentes) que cometen delitos/infracciones. El grave 
hacinamiento, la falta de idoneidad en el servicio resocializador y las críticas constantes al sistema de medio cerrado, crean una apariencia de contención que se impone sobre la función de resocialización y rehabilitadora de la medida socioeducativa en medio cerrado. "El modo más claro de apreciar la dimensión de este fenómeno quizás esté en recordar que incluso conduce a la rehabilitación de nociones -abandonadas hace años en el discurso teórico de los ordenamientos penales continentales- como la de Inocuización" (Cancio Meliá, 2006, p.10).

En este sentido, parece evidente, en lo que se refiere a la realidad del Derecho positivo, que la tendencia actual del legislador es la de reaccionar con "decisión" dentro de muchos sectores diversos de regulación en el marco de la "lucha" contra la criminalidad, es decir, con un incremento de las penas previstas. Un ejemplo, tomado del Código penal español, lo constituyen las infracciones relativas al tráfico de drogas tóxicas o estupefacientes y sustancias psicotrópicas: la regulación contenida en el texto de 1995 duplica la pena prevista en la regulación anterior, de modo que la venta de una dosis de cocaína - considerada una sustancia que produce "grave daño a la salud", lo que da lugar a la aplicación de un tipo cualificado- supone una pena de tres a nueve años de privación de libertad (frente a, aproximadamente, uno a cuatro años en el anterior Código), potencialmente superior, por ejemplo, a la correspondiente a un homicidio por imprudencia grave (uno a cuatro años) o a un delito de aborto doloso sin consentimiento de la madre (cuatro a ocho años) en los términos previstos en el mismo "Código penal de la democracia" apoyado parlamentariamente por la izquierda política.

(Cancio Meliá, 2006, pp.10-11).

Existen en los diversos Centros Juveniles decisiones que carecen de idoneidad; es más bien, una suma de desaciertos que ocasionan contrariedades severas en el sistema resocializador. En ese sentido, el presente trabajo muestra de qué manera se pueden mitigar algunas extralimitaciones de la administración de dichos centros.

Así, por ejemplo, una de las medidas a tener en cuenta en un escenario de fuga puede ser que, cada vez que se solicita la recaptura administrativa de algún menor en caso de fuga, se debe analizar los motivos de su encierro, si éste utilizó violencia para huir del medio cerrado, y además, conocer el Programa del que formaba parte. Estas características básicas ayudarán a determinar si es o no menester, recapturar para mantener al adolescente en reclusión. En caso que se determine la reintegración del menor en el Centro Juvenil, el adolescente debe volver al Programa que desarrollaba. Nótese que la recaptura y reclusión, ocasionada por la fuga, no debe incluir daño físico o psíquico; más aún, cuando el escape fue cometido sin violencia ni daños. Solo se efectúa la recaptura para que el menor continúe en el medio cerrado para cumplir con la finalidad -muchas veces alterna y no deseada- de los Centros de Diagnóstico y Rehabilitación. ¿Es la fuga no violenta 
un acto grave de indisciplina? $\mathrm{O}$ ¿es un mecanismo de auto defensa frente al hecho de vivir en un mundo de condiciones de riesgo personal?

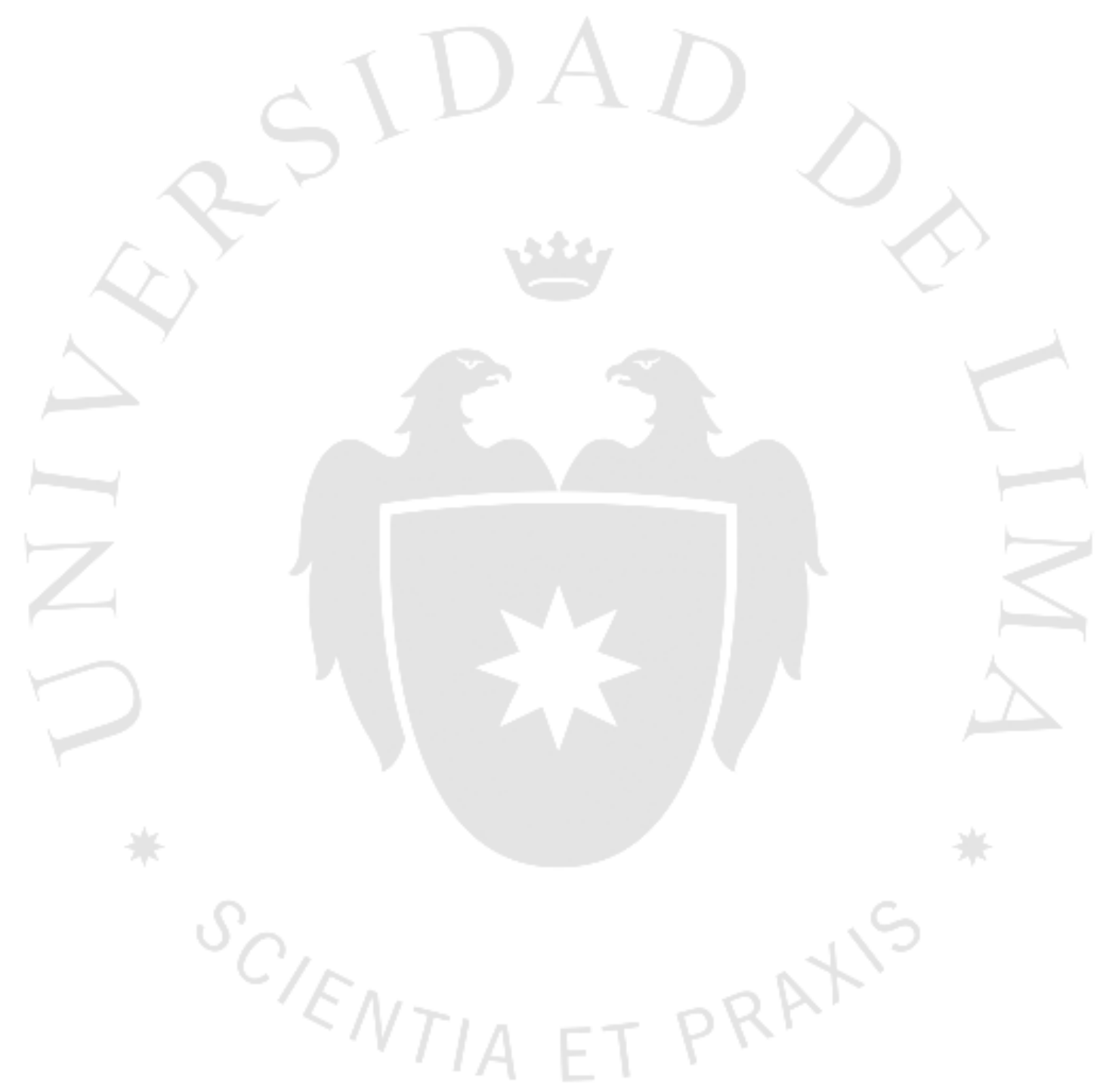




\section{CAPÍTULO III: BASES NORMATVAS}

\section{1.- La Constitución, análisis y respuestas de nuestro acervo normativo fundamental}

La teoría del Estado define los límites y prerrogativas que mantiene la Constitución del país; en tal camino, expondremos las ideas de aquellos que brindaron los cimientos para la formación de su teoría. Es, en definitiva, apropiado revisar el estado natural de las personas, las conjeturas que han determinado nuestra existencia y -sobre todo- aquellos instintos que definen y hacen posible la supervivencia de la especie. En efecto, el Derecho Constitucional otorga atribuciones que hacen posible reclamar el cumplimiento de las garantías y derechos fundamentales; es también la línea límite de las propuestas, no podremos transgredir ninguna disposición fundamental.

En ese sentido, Rousseau utilizó el concepto de la tabula rasa -de Locke- para explicar el estado natural de las personas; él determina que todas las personas nacen sin ninguna información y absorben aquello que el medio disponga para ellas. La necesidad de agruparse surge, pues el conocimiento es específico y poco abundante dentro del grupo determinado (medio en el que se nace). En este contexto las personas buscan agruparse, intercambiar información, mejorar sistemas; en suma, beneficios.

El contrato social, evidencia para Rousseau una necesidad por la búsqueda del beneficio mutuo, jamás apela a la destrucción; contrario a las ideas de Hobbes que utilizó el concepto de Homo homini lupus para determinar la necesidad de un ente poderoso (Leviatán). La Constitución del Estado moderno peruano mantiene los ideales de Rousseau, de manera adicional se incluyen las ideas de Montesquieu -quien se ubicó en el punto medio, entre Hobbes y Rousseau-. El autor del Espíritu de las Leyes indica que, en un estado natural, el hombre es un ser débil, torpe y -por ende- poco valiente; y por tanto, se agrupa por la necesidad de supervivencia, busca seguridad y fuerza en el grupo.

En consecuencia, la Constitución que nos delimita, coloca como idea capital a la cooperación; vinimos influenciados directamente del Contrato Social de Rousseau, no solo en conceptos políticos, sino también en todos los temas en donde resulte pertinente y útil su empleo. El mercado funciona por la cooperación y mezcla de habilidades específicas; una suma de virtudes que alivia obstáculos y coloca en un lugar privilegiado al ser humano. 
Mutatis mutandis en un contexto de crimen, -y atendiendo que el objetivo principal es la suma de habilidades para lograr un resultado positivo aplicable a todas las partes que intervienen en nuestros sistema- utilizamos el marco constitucional que reconoce los buenos valores, la defensa por los derechos humanos fundamentales; todo ello con el propósito de atender los problemas que presenta nuestro sistema penitenciario. El Perú desarrolla un sistema penitenciario corrosivo, con un problema de hacinamiento que va cobrando importancia (132\% de hacinamiento para finales del año 2015 y 500\% de sobre población penitenciaria en el Departamento de Chiclayo) (Fernández, 2006).

Ahora bien, el artículo 1 de la Constitución indica que todo control social se orienta en la defensa de la persona humana y al respeto de la dignidad; ambas configuran el fin supremo de la sociedad, del Estado. Aquella idea impulsa esta investigación, para evidenciar la realidad de aquellos que no tienen voz, que están encerrados y algunas veces silenciados por la cultura del castigo y una alta percepción de criminalidad; por ello se aprecian factores de maltrato contra la persona, prácticas guiadas por la violencia que se derivan del menoscabo de la dignidad.

Para desarrollar la idea Dignidad es necesario puntualizar que el derecho utiliza dos conceptos diferentes respecto a tal término. La primera acepción tiene un criterio ontológico, y atribuye esta virtud a todos los seres humanos. Es decir, una persona es digna por el simple hecho de existir. En cambio, otro grupo de la doctrina explica que la dignidad se adquiere, es un valor que se deriva del trabajo o mérito; no es propio de la condición humana.

(...) deriva de la raíz indoeuropea dek, que significa: tomar, recibir, saludar, honrar. De dicha raíz deriva el sustantivo dekos, que expresa: adorno, elegancia, porte, gloria, honor. En latín, "digno" puede derivar de dic-nus (de donde viene decente y decoro) (...) que merece (...). Por lo tanto, el concepto de dignidad se encuentra entrelazado con el de mérito, que tiene su origen el latín mèritum (cosa merecida, merced, recompensa, premio), que deriva de merèri (adquirir, ganar, obtener, tener una parte, una porción), que tiene la misma raíz del griego Mer-is (porción, lucro).

(Calise, 2010, pp.133-134).

El autor de la tesis se decanta por la primera definición de dignidad, ya que, en contrario, no se considerará digna a una persona que nace en ambiente de escasos recursos económicos, culturales o sociales. Aquella persona le costará salir de $s u$ realidad, y hasta que no lo consiga, no será considerado digno; en cambio si la persona nace bajo condiciones buenas, en conductas y propiedades, será más fácil que sea considerada digna, por el lugar en el que proviene, cómo vive, las cosas que posee, los libros que lee y la cultura de desarrollo que lo circunda. 
Asimismo, la asignación de valor que se brinda al "mérito" es subjetiva, cada persona asigna "el mérito" de una manera distinta, según la experiencia que haya mantenido en la vida. Es por tanto, la asignación de dignidad -para un grupo de la doctrina- resulta de la aplicación del método praxiológico, es un examen, una aproximación: un valor. No obstante, este trabajo mantiene un ánimo garantista, por tanto Dignidad es una atribución de carácter continuo, inalienable, propio del ser humano, tan natural como lo es la atribución de racionalidad en el ser.

En este trabajo además se postula que el refuerzo de la dignidad es el mérito propio o de terceros en la ayuda a obtener condiciones de vida adecuadas, sin vejámenes y que mantienen un estado de bienestar apto para lograr que la libertad pueda ejercitarse de manera interna y así lograr el propósito que cada uno está destinado a alcanzar.

Se dice que una persona tiene carácter cuando sus deseos e impulsos son suyos propios, es decir, son la expresión de su propia naturaleza, desarrollada y modificada por su propia cultura. El que carece de deseos e impulsos propios no tiene más carácter que una máquina de vapor. $\mathrm{Si}$, además de ser suyos, sus impulsos son fuertes y están dirigidos por una voluntad poderosa, esa persona tiene un carácter enérgico. Quienquiera que piense que no debe facilitarse el desenvolvimiento de la individualidad de deseos y de impulsos debe mantener que la sociedad no tiene necesidad de naturalezas fuertes -que no es mejor por encerar un gran número de personas de carácter- y que no es deseable un elevado promedio de energía.

(Stuart Mill, 2013, p.156).

Existen situaciones que merman el concepto base de dignidad, y allí se comparte la posición del Estado a través de su Constitución, ya que coloca el respeto (en primer lugar) a la condición de persona humana digna.

En adición, el artículo 2 de la Constitución del Perú, con un conjunto de acápites (incisos) defiende todo aquello que el sometimiento de un Centros Juvenil para menores que lamentablemente hoy no representa. La integridad moral, física y psíquica es continuamente afectada, el resultado frente a la práctica de contención y violencia es el siguiente: internos que poseen más agresividad y mejores conocimientos, y educadores o guardianes que mantienen una cuota importante de soberbia, abuso de poder que permite la corrupción, el tráfico de drogas y la asignación castigos no estipulados en la norma penal. El sistema de castigo en medio cerrado es, al parecer, una isla con reglas distantes a las determinadas por la Constitución.

Los adolescentes que afrontan una medida socio-educativa de internamiento en medio cerrado sufren del estigma social, la comunidad discrimina su condición, los aleja y no prestan alguna atención a sus integrantes. 
En el inciso 22 del artículo 2, se establece que también tienen derecho a la paz, tranquilidad, disfrute del tiempo libre y descanso que puede ser entendido como el derecho a salir al patio del establecimiento penitenciario. Ello no es factible en un ambiente de hacinamiento donde, por ejemplo, solo existen 6-8 servicios higiénicos para una población de 160-200 menores ${ }^{9}$. Además, paz y tranquilidad serán elementos poco cotidianos en los días de encierro; en esas condiciones las agresiones son constantes (a través de la población castigada, de la administración judicial y también de la mayor parte de la sociedad con una alta percepción de criminalidad).

Asimismo, respecto a las "seguridades personales" identificadas en el inciso 24 del artículo 2 de la Constitución, con especial incidencia en el literal h, en relación a la violencia psíquica, moral y física que no debe sufrir ninguna persona. Los internos privados de su libertad ambulatoria, no deben ser tratados con violencia. Los tratos humillantes son parte de una receta penitenciaria que no debe continuar. Así también, cuando el artículo 3 se refiere a la dignidad que se reconoce en todas las personas que conforman la sociedad; no excluye a los internos. Un criminal que mantiene su dignidad tendrá más posibilidad de resocialización y se debería respetar la dignidad de las demás personas. Además, el Capítulo II del mismo cuerpo legislativo, incide en los adolescentes. Establece una tarea especial dirigida a la Comunidad y al Estado con respecto a ellos.

El artículo 14 de la Constitución señala el deber de brindar un sistema de educación satisfactorio; recordemos que la falencia de esta obligación se configura como uno de los orígenes del crimen. Muchos de los infractores no tienen educación completa, carecen de formación técnica o profesional. Con la mejora de las condiciones de educación se obtendría una reducción directa con el índice de criminalidad. El mismo razonamiento se aplica para el artículo 17 (educación).

Así también, en el artículo 22 de la Constitución establece que el derecho al trabajo conlleva a la realización de la persona. Es decir, es mediante el trabajo que el ser humano obtiene la libertad interior, al respecto John Stuart Mill propone que "En proporción al desenvolvimiento de su individualidad, cada persona adquiere un mayor valor para sí mismo y es capaz, por consiguiente, de adquirir un mayor valor para los demás. Se da una mayor plenitud de vida en su propia existencia y cuando hay más vida en las unidades hay también más en la masa que se compone de ellas" (Stuart Mill, 2013, p.60). Por tanto, cuando un adolescente cumple la medida de internamiento ¿podrá también escapar del entorno que lo llevó a cometer el ilícito penal? ¿Será

\footnotetext{
${ }^{9}$ Dato obtenido por observación directa durante la visita realizada por el autor de esta investigación al Centro Juvenil de Diagnóstico y Rehabilitación de Lima, verano 2017.
} 
alto el grado de dificultad para conseguir trabajo luego de esta experiencia? ¿Esa persona podrá sentirse libre, valorable y realizada? Si la respuesta es negativa, la finalidad rehabilitadora no se cumplirá.

\section{2.- Estándares impuestos por la Organización de las Naciones Unidas, Organización de Estados Americanos y la Corte Interamericana de Derechos Humanos.}

El año 2005 la Organización de Naciones Unidas (en adelante ONU) define los parámetros en la ejecución de la punición, recubre de humanidad al sistema penitenciario y establece mínimas condiciones que hacen posible la resocialización de las personas que cumplen una condena. Este ánimo es compartido por otras entidades internacionales como la Organización de Estados Americanos (OEA) y el instrumento que vela por su cumplimiento y también establece sanciones para aquellos Estados que incumplan las normativas es la Corte Interamericana de Derechos Humanos (CIDH).

En vista de ello y en primer lugar, acudiremos a los principales lineamientos determinados por la ONU, Reglas mínimas para el tratamiento de reclusos (Naciones Unidas, 1977) para establecer si el sistema implementado en el Perú, vulnera o no los estándares definidos por instituciones internacionales.

Dentro de las reglas de aplicación general encontramos que resulta necesaria la "Separación de Categorías" o "Segregación por Categorías". Esta idea incluye conceptos que diferencian a las personas por sexo, edad, antecedentes, motivo de detención, etc. Asimismo, aquellos que cumplen una medida preventiva deben ser separados de aquellos que tienen una medida firme.

En el caso estricto de menores, el ambiente utilizado para el programa denominado "Bienvenida" utiliza 40 camas en un solo una habitación. En él conviven menores que han cometido distintos crímenes (las únicas separaciones que se realizan suceden para quienes no son mayores de 15 años y a aquellos infractores que tienen una opción sexual diferente). En otros programas, son aproximadamente 80 los menores que duermen en camarotes, también en un mismo ambiente ${ }^{10}$.

\footnotetext{
${ }^{10}$ Las cantidades fueron facilitadas por los miembros de administración de los Centros Juveniles de Diagnóstico y Rehabilitación, de obtuvieron en diversas visitas a la Gerencia Nacional encargada de los Centros Juveniles.
} 
Frente a ello, los estándares internacionales apuntan a que cada menor ocupe una sola cama, que tenga su espacio, sin embargo, estos afanes quedan mermados por los niveles de hacinamiento, verbigracia el Centro Juvenil de Diagnóstico y Rehabilitación de la ciudad de Piura, cuatro menores ocupan un solo camarote; es decir, una sola cama es compartida por dos personas ${ }^{11}$.

Del mismo modo, se dispone normativamente que las instalaciones sanitarias deben estar disponibles para todos los internos, en el momento adecuado "en forma aseada y decente". Ello no sucede en el Perú, más aún cuando los centros juveniles para adolescentes están hacinados; ello hace imposible que se cumpla aquella medida sanitaria.

En adición, se debe resaltar que están prohibidas todas las formas de castigos corporales: los encierros en las celdas oscuras, tratos inhumanos, degradantes o crueles. El daño o castigo físico no es concebido como una medida disciplinaria. En ese sentido es necesario comentar que existe un "patio" denominado como el "PAI Cielo" (proveniente del Programa de Atención Intensiva, y Cielo, porque se encuentra encima de la Dirección del Centro Juvenil de Diagnóstico y Rehabilitación de Lima): el objetivo que circunda este lugar es controlar conductas a través del aislamiento, castigo físico y del racionamiento del alimento ${ }^{12}$.

57. La prisión y las demás medidas cuyo efecto es separar a un delincuente del mundo exterior son aflictivas por el hecho mismo de que despojan al individuo de su derecho a disponer de su persona al privarle de su libertad. Por lo tanto, a reserva de las mediadas de separación justificadas o del mantenimiento de la disciplina, el sistema penitenciario no debe agravar los sufrimientos inherentes a tal situación. 58. El fin y la justificación de las penas y medidas privativas de libertad son, en definitiva, proteger a la sociedad del crimen.

(Naciones Unidas, 1977).

Es probable que algunos de los menores infractores, violentos y no violentos, impulsados por las condiciones de encierro y el influjo de los internos, presenten una tendencia para convertirse también en abusadores; el círculo nocivo se refuerza donde los delitos/infracciones y abusos de poder se generalizan en un clima de violencia.

A su vez, el punto 61 señala lo siguiente:

61. En el tratamiento no se deberá recalcar el hecho de la exclusión de los reclusos de la sociedad, sino, por el contrario, el hecho de que continúan formando parte de ella. Con ese fin debe recurrirse,

\footnotetext{
${ }^{11}$ Las cantidades fueron facilitadas por los miembros de administración de los Centros Juveniles de Diagnóstico y Rehabilitación, de obtuvieron en diversas visitas a la Gerencia Nacional encargada de los Centros Juveniles.

12 Esta información fue obtenida gracias a "Julián" caso exitoso de resocialización que hoy trabaja para la administración pública.
} 
en lo posible, a la cooperación de organismos de la comunidad que ayuden al personal del establecimiento en su tarea de rehabilitación social de los reclusos.

(Naciones Unidas, 1977).

Así también, en el mismo ámbito, la OEA se ha manifestado a favor de las prácticas positivas definidas por la ONU y también cuestiona a aquellos países en que se incumple con las determinaciones. Sobre el particular, mediante un informe realizado por la Comisión Interamericana de Derechos Humanos, se señalaron las mayores contravenciones del sistema en Honduras (Comisión Interamericana de Derechos Humanos, 2015).

En ese sentido el Informe "Situación de Derechos Humanos en Honduras" evidencia en su Capítulo 7 "Situación de las Personas Privadas de su Libertad" (CIDH, 2015, p.207) (puntos 509, $510,511,556)$ que existe un porcentaje muy importante $(47.98 \%)$ de procesados penales que se encuentran detenidos en un centro penitenciario. Este elevado porcentaje refleja un manejo improvisado y muy distante del debido proceso y de las garantías constitucionales.

Asimismo, el informe evidencia el grave hacinamiento en Honduras, establece los mecanismos más eficientes para contrarrestar aquel problema con el propósito de no empeorar la situación de los detenidos (puntos 522, 524, 527). Adicionalmente el punto 562 de aquel informe observa la realidad de los centros penitenciarios de menores y resalta la formación de pandillas como la "Mara 18" e indica que existen rivalidades con otros grupos, amenazas y violencia expresa. En suma, la Comisión Interamericana solicita el monitoreo sistemático de la situación de los derechos humanos en los centros juveniles y penitenciarios del país; parte de este trabajo es evidenciar/monitorear aquellos actos que acarrean contravenciones de naturaleza fundamental.

El rol que cumple la Corte Interamericana de Derechos Humanos es esencial y primordial para mantener un equilibrio en el sistema resocializador y asimismo, obtener resultados positivos en el control de la criminalidad. En ese camino, como este trabajo desarrolla, se enseña el caso del Estado de Pernambuco en Brasil. En este ejemplo, observamos el papel -no solo de espectadorde aquella Corte Internacional, sino también su interés en aquellos sistemas que actúan con resultados contraproducentes. Por tanto, esta Corte determina que los operadores de justicia deben de observar el nivel de hacinamiento del medio cerrado antes de emitir una medida de internamiento preventivo o efectivo; toda vez que el nivel de hacinamiento tiene una implicancia directa con la posibilidad resocializadora del infractor. 


\section{3.- Principales normas internacionales:}

Estos límites de ejecución punitiva fijan el alcance en las medidas aplicables para los menores infractores del país. El cumplimiento de estas normas evita que la vivencia de un adolescente interno conlleve una etapa discriminadora, abusiva y limitadora de oportunidades importantes. En contraposición, los centros juveniles representan para ciertos adultos (de recurrente comportamiento delictivo) el punto de partida para una vida criminal.

En ese sentido, se analizarán los puntos más relevantes de aquellas normativas, su utilidad y empleo en el programa resocializador.

\subsection{1.- Reglas Mínimas de las Naciones Unidas para la administración de justicia de menores (Reglas de Beijing)}

En primer lugar, Las Reglas de Beijing: explican que la administración de la justicia de menores debe estar circundada por los siguientes principios: a) se deben proteger sus derechos básicos (no violencia sobre el cuerpo, no tortura ni hostigamiento), b) se debe satisfacer las necesidades de la sociedad, es decir, reducir el índice criminal. Ello no ocurre debido a que cada año, pese a aumentar las penas y ser "más duros" contra el crimen, se incrementan el número de infractores y el daño que sufre la víctima también se va intensificando. Finalmente, c) Aplicar cabalmente y con justicia las reglas que mantiene el presente cuerpo normativo. En ese sentido, se protege la integridad de los menores infractores, se busca una equidad entre el pedido de la sociedad y la acción del Estado, y finalmente se pide aplicar con responsabilidad y humanidad las reglas mínimas que mantiene este conjunto de normas.

Del mismo modo, en el punto 5, "Objetivos de la justicia de menores”, se explica que “(...) cualquier respuesta a los menores delincuentes será en todo momento proporcionada a las circunstancias del delincuente y del delito" (Naciones Unidas, 1985, p.6). Es decir, el castigo responde a una medida de proporción que el Estado peruano no cumple. En la normativa interna encontramos que la protección al bien jurídico patrimonio es más protegida (merece mayor castigo) que la vida. ${ }^{13}$

El punto 7 del mismo documento expone que se debe de brindar especial protección y atención a las garantías procesales básicas como la presunción de inocencia. Dicho principio en la práctica se vulnera de manera muy continua, esto se debe en gran parte por la cultura de

\footnotetext{
${ }^{13}$ El capítulo que desarrolla este tema se titula: Consecuencias de la desproporción penal.
} 
victimización, una prensa iracunda, mediática e interesada; además un microclima más nocivo y peligroso creado por políticos que buscan votos y márgenes de aprobación.

En la segunda parte de este conjunto de reglas mínimas, encontramos que se busca la adopción de la medida más óptima para el desarrollo y bienestar del menor. En ese aspecto se pide de manera explícita que el juez examine la posibilidad de poner al menor en libertad. Se considera que la aplicación de una "pena privativa de libertad" o "medida socio educativa" -el "título" no discrimina la naturaleza de encierro ni función resocializadora- es de última ratio. Se pretende evitar un clima más nocivo, violento y ocioso; encerrar a una persona es útil cuando represente un peligro para la sociedad y sean mayores los beneficios que los costos.

En esta sección también se refuerza la idea de mantener el bienestar del menor, que no sufra ningún daño. En la realidad, arrojar a un menor a un centro juvenil en el Perú, representa un quiebre en su bienestar y la probabilidad cierta de sufrir daños físicos y psicológicos.

Así también, en el aspecto que regula la remisión (punto 11), se incide en que se deben facilitar programas de supervisión, implementación de una justicia restaurativa y compensación a las víctimas. Es decir, se reafirma el ánimo por evitar que un menor sea encerrado, además se busca la implementación de una justicia que restituya los daños, que se compense a las víctimas por las pérdidas; que el sentimiento de impunidad termine. La victimización se incrementa debido a que los afectados no reciben apoyo, no se reintegra el bien perdido o dañado; si la víctima recibiera un atisbo de ayuda, el interés en el tema criminal se incrementaría, y con ello, muchas ideas con soluciones mitigarían el estigma de la criminalidad.

Se debe resaltar además, que no existen agentes policiales especializados que traten de manera exclusiva o a menudo con menores, o que se dediquen a prevenir infracciones juveniles (punto 12). Las normas mínimas mantienen un ánimo preventivo, si agentes policiales buscan especializarse en el inicio de la "carrera criminal" evitarán la formación de pandillas o grupos del crimen organizado. La especialidad no es una condecoración más, es -en un contexto de crimenuna necesidad para un sistema beneficioso, durable y de continuidad virtuosa.

Del mismo modo, es de suponer que la "prisión preventiva" es un recurso último y que debe utilizarse por el menor tiempo posible. "13.2 Siempre que sea posible, se adoptarán medidas sustitutorias de la prisión preventiva, como la supervisión estricta, la custodia permanente, la asignación a una familia o el traslado a un hogar o a una institución educativa" (Naciones Unidas, 
1985, p.8). Sucede en nuestro país lo contrario, la primera alternativa y "más provechosa" es la prisión preventiva.

En aquel camino, resaltar el punto 16:

16.1 Para facilitar la adopción de una decisión justa por parte de la autoridad competente, y a menos que se trate de delitos leves, antes de que esa autoridad dicte una resolución definitiva se efectuará una investigación completa sobre el medio social y las condiciones en que se desarrolla la vida del menor y sobre las circunstancias en las que se hubiere cometido el delito.

(Naciones Unidas, 1985, p.9).

Por tanto, antes de establecer una sentencia firme, se debe investigar el medio social, cultural y económico del menor, ello determinará la utilidad y necesidad de una medida socioeducativa.

Además, también se establece que sólo se impondrá la privación de libertad personal del menor cuando éste haya cometido un acto grave donde concurra violencia contra la víctima o por la reincidencia en cometer otras infracciones penales graves. Este principio es invertido por los operadores judiciales del país, prueba de ello es el hacinamiento que existe en nuestros centros juveniles y cárceles. Para el caso concreto del Centro Juvenil de Diagnóstico y Rehabilitación de Santa Margarita que demuestra un porcentaje de hacinamiento del $20 \%$-con capacidad para albergar a 80 menores, pero en setiembre de 2016 ya tiene a 100 menores-, además de ello $40 \%$ de su población cometieron infracciones en contra del patrimonio, robo y hurto, $30 \%$ tráfico ilícito de drogas y el 30\% restante cometieron la infracción grave de parricidio. Estos porcentajes son emulados en gran medida por los demás centros que privan la libertad, el porcentaje mayor siempre lo representarán las infracciones en contra del patrimonio, como no se aplica una justicia retributiva el camino es condenar de manera efectiva; el 30\% estará representado por aquellas personas que sí representan peligro para la sociedad, sí cometieron infracciones graves.

En adición, estas reglas mínimas impulsan en el punto 28 el uso pronto y frecuente de la concesión de la libertad condicional; de manera reiterativa las reglas mínimas mantienen el propósito de alejar a los menores de estos medios nocivos y perjudiciales para su desarrollo y vida futura.

El último punto útil para nuestro análisis establece que se deben organizar y fomentar investigaciones que evalúen las tendencias, problemáticas y alternativas de solución; todo ello con el propósito de brindar bienestar y contrarrestar problemas suscitados. Esto sólo será posible 
cuando la sociedad intervenga de manera activa en la lucha contra el incremento de la criminalidad; los caminos más eficientes se darán por la concatenación de ideas, la suma de garantías humanitarias y opiniones especializadas.

\subsection{2.- Convención Americana sobre Derechos Humanos (Pacto de San José)}

La presente convención establece garantías precisas para el tema que desarrolla esta investigación. Se encuentran focalizadas en el artículo 5, "Derecho a la Integridad Personal":

1. Toda persona tiene derecho a que se respete su integridad física, psíquica y moral.

2. Nadie debe ser sometido a torturas ni a penas o tratos crueles, inhumanos o degradantes. Toda persona privada de libertad será tratada con el respeto debido a la dignidad inherente al ser humano.

3. La pena no puede trascender de la persona del delincuente.

4. Los procesados deben estar separados de los condenados, salvo en circunstancias excepcionales, y serán sometidos a un tratamiento adecuado a su condición de personas no condenadas.

5. Cuando los menores puedan ser procesados, deben ser separados de los adultos y llevados ante tribunales especializados, con la mayor celeridad posible, para su tratamiento.

6. Las penas privativas de la libertad tendrán como finalidad esencial la reforma y la readaptación social de los condenados.

(OEA, 1969).

Es menester recordar la relevancia del bien jurídico dignidad, aunque abstracto, necesario para que el bien fundamental Vida pueda manifestarse. En ese sentido, no puede entenderse como respeto por este bien fundamental, situaciones como las siguientes: alejar a personas a un medio precario, pequeño y con márgenes de hacinamiento, con un solo patio, sin áreas verdes, muy pocos servicios higiénicos (todos compartidos), manteniendo castigos corporales, psicológicos y muy duraderos (mínimo de un mes y máximo de 3 meses). Estos hechos no pueden considerarse como conservadores de la dignidad inherente al ser humano.

Se considera que la persona que afronta la imposibilidad de manifestar su libertad ambulatoria, debe sufrir los más duros vejámenes y mantener una vida en miseria. La sociedad no es consciente del factor estructural que posee, la diferencia en los intereses de las personas, y la razón de las conductas delictivas. La oportunidad, tolerancia, buenos tratos y consideración son bases para la vida en sociedad; asimismo, estas cualidades y valores combaten los efectos nocivos de la criminalidad. 


\subsection{3.- Convención sobre los Derechos del Niño}

La relación de los siguientes artículos mantiene cuidados que la administración penitenciaria del país no tiene en mucha consideración, pese a ser uno de los lineamientos que fundamentan su acción. En ese sentido se compiló una lista de artículos que ayudarán a mejorar las condiciones de los centros juveniles y, en consecuencia, tendrá reflejo en el bienestar de la sociedad.

En el Artículo 25 de aquella convención, determina que los Estados Partes reconocen el derecho del menor (que ha sido internado en un establecimiento por las autoridades competentes para los fines de atención, protección o tratamiento de su salud física o mental) a un examen periódico del tratamiento al que esté sometido. Es decir, se deben analizar las condiciones de mejoría o empeoramiento del menor, exámenes periódicos determinarán aquello que necesite refuerzo y también mostrará las cosas innecesarias que acarrean efectos contraproducentes y generan más gastos.

Asimismo, el Artículo 37 se establece que los Estados Partes velarán porque:

a) Ningún niño sea sometido a torturas ni a otros tratos o penas crueles, inhumanos o degradantes. No se impondrá la pena capital ni la de prisión perpetua sin posibilidad de excarcelación por delitos cometidos por menores de 18 años de edad;

b) Ningún niño sea privado de su libertad ilegal o arbitrariamente. La detención, el encarcelamiento o la prisión de un niño se llevará a cabo de conformidad con la ley y se utilizará tan sólo como medida de último recurso y durante el período más breve que proceda;

c) Todo niño privado de libertad sea tratado con la humanidad y el respeto que merece la dignidad inherente a la persona humana, y de manera que se tengan en cuenta las necesidades de las personas de su edad. En particular, todo niño privado de libertad estará separado de los adultos, a menos que ello se considere contrario al interés superior del niño, y tendrá derecho a mantener contacto con su familia por medio de correspondencia y de visitas, salvo en circunstancias excepcionales;

d) Todo niño privado de su libertad tendrá derecho a un pronto acceso a la asistencia jurídica y otra asistencia adecuada, así como derecho a impugnar la legalidad de la privación de su libertad ante un tribunal u otra autoridad competente, independiente e imparcial y a una pronta decisión sobre dicha acción.

(UNICEF, 1989).

Por tanto, los tratos degradantes no pueden sugerirse como métodos de contención o disuasivos de conductas. Se subraya nuevamente el carácter de última ratio para la aplicación de una pena que prive la libertad de las personas. La dignidad es también uno de los pilares para este cuerpo normativo.

En el literal "c)" resulta necesario hacer un comentario respecto al régimen de visitas y el contacto con las familias: se tiene como prohibida la visita que intenta realizar el padre del bebé que se mantiene también encerrado en el centro juvenil de mujeres. Los hijos de las infractoras 
crecen junto con sus madres en un ambiente de encierro y no pueden conocer a su padre. Son menores de edad atrapados en un contexto donde los prejuicios religiosos y papeleo administrativo, tiene mayor importancia que el futuro y bienestar del niño que crece en un clima de encierro.

Ahora bien, respecto a la "asistencia adecuada" es muy difícil obtener una, ya que ello implica una buena contraprestación por el servicio. Una defensa adecuada reúne pruebas, analiza estudios y requiere de una formación especializada y de alta calidad, estas características requieren de mucho dinero, y por tanto, el precio establecido para una defensa de este tipo no puede ser afrontada por un menor o adulto que proviene de un medio con escasos recursos económicos. Ello empuja al sistema (con esperanzas) a confiar en el buen criterio del juez.

Finalmente, se espera que la desproporción en los castigos y las medidas violentas de contención sean mitigadas por prácticas humanitarias: que incluyan una justicia retributiva, indemnizaciones por errores judiciales y por los excesos en la aplicación de condenas preventiva, trabajo remunerado, sistemas de salud que contrarresten enfermedades adictivas, etc.

“Artículo 39: Los Estados Partes adoptarán todas las medidas apropiadas para promover la recuperación física y psicológica y la reintegración social de todo niño víctima de: cualquier forma de abandono, explotación o abuso; tortura u otra forma de tratos o penas crueles, inhumanos o degradantes; o conflictos armados. Esa recuperación y reintegración se llevarán a cabo en un ambiente que fomente la salud, el respeto de sí mismo y la dignidad del niño.” (UNICEF, 1989).

\subsection{4.- Reglas de las Naciones Unidas para la protección de los menores privados de libertad (Reglas de la Habana)}

Por último, el contexto ideal para el desarrollo de una medida socio-educativa es brindado por las Reglas de la Habana. Se observa en primer término la definición del concepto de privación de libertad.

En alcance y aplicación de las reglas: Por privación de libertad se entiende toda forma de detención o encarcelamiento, así como el internamiento en un establecimiento público o privado del que no se permita salir al menor por su propia voluntad, por orden de cualquier autoridad judicial, administrativa u otra autoridad pública.

(Naciones Unidas, 1990).

Queda claro por tanto, que las medidas socio-educativas representan un encarcelamiento, privan la libertad de un individuo, racionan sus alimentos, disponen los momentos destinados para el entretenimiento, paseo, trabajo, talleres, se establece un horario para despertar, dormir. 
Se debe resaltar de manera positiva que el Perú está implementando cada vez más centros de detención en medio abierto. "En Clasificación y asignación: (...) Deben organizarse centros de detención abiertos para menores. Se entiende por centros de detención abiertos aquéllos donde las medidas de seguridad son escasas o nulas" (Naciones Unidas, 1990). Existe una necesidad imperante para que se implementen más "medios abiertos", ellos conllevan a un mejor comportamiento, no desarrollan el uso de la fuerza y brindan mejores oportunidades de resocialización. Estos mecanismos necesitan continuar empleándose en todos los Departamentos del país, y con especial importancia en aquellos lugares donde el índice criminal es elevado, como en el caso de Chiclayo y Piura donde sus centros reclusorios sufren un hacinamiento muy fuerte.

De la visita realizada al Centro Juvenil de Diagnóstico y Resocialización para mujeres (Santa Margarita) se pudo comprobar que existen muy pocos servicios higiénicos para todas las menores; además, por la antigüedad del local y de su estructura -los señores de la administración señalan que-, las tuberías se obstruyen de manera constante, ello acarrea el colapso continuo de los servicios higiénicos y genera que del universo precario de baños se reduzca aún más y solo puedan utilizarse algunos pocos. "En Medio físico y alojamiento: Los menores privados de libertad tendrán derecho a contar con locales y servicios que satisfagan todas las exigencias de la higiene y de la dignidad humana” (Naciones Unidas, 1990).

Asimismo, de aquella visita (Santa Margarita), también se comprobó que solo existe un patio muy pequeño, que no es al aire libre, y en él se dificulta practicar alguna actividad física. Mantienen un pequeño gimnasio en otra sección del centro, techado, y la disponibilidad de uso no es constante. En adición, se considera que el aire libre es esencial para disipar las tenciones ocasionadas por la naturaleza del encierro, el deporte genera endorfinas que combaten la depresión y ello conlleva a mantener un mejor "clima" sin menos violencia. "En actividades recreativas: Todo menor deberá disponer diariamente del tiempo suficiente para practicar ejercicios físicos al aire libre si el clima lo permite, durante el cual se proporcionará normalmente una educación recreativa y física adecuada." (Naciones Unidas, 1990). Un ambiente tan estrecho para tantas personas demuestra el desinterés de la sociedad en los temas penitenciarios, las consecuencias de este olvido recaen en la seguridad ciudadana y daños graves a la sociedad.

Así también, estas reglas consideran que debe existir una comunicación constante y adecuada con su entorno: familiares, amigos, parejas, etc. Ello los invita a volver a la sociedad cotidiana, a compartir y comenzar -o continuar- con aquello que se tuvo que detener por vulnerar 
una ley penal. En un contexto de encierro sin posibilidad de comunicación, el teléfono se convierte en el beneficio más preciado y esperado. Sin embargo, la administración de "Santa Margarita" solo mantiene un solo teléfono público que las menores utilizan cada 15 días. Este trabajo considera que el beneficio genera mejores resultados que los castigos, en ese sentido, premiar a una menor con una llamada telefónica, generando privacidad y constancia, generan hábitos que conllevarán a buena conducta exenta de castigos.

En Contactos con la comunidad en general: Se deberán utilizar todos los medios posibles para que los menores tengan una comunicación adecuada con el mundo exterior, pues ella es parte integrante del derecho a un tratamiento justo y humanitario y es indispensable para preparar la reinserción de los menores en la sociedad. Deberá autorizarse a los menores a comunicarse con sus familiares, sus amigos y otras personas o representantes de organizaciones prestigiosas del exterior, a salir de los centros de detención para visitar su hogar y su familia, y se darán permisos especiales para salir del establecimiento por motivos educativos, profesionales $u$ otras razones de importancia. Todo menor tendrá derecho a recibir visitas regulares y frecuentes, en principio una vez por semana y por lo menos una vez al mes, en condiciones que respeten la necesidad de intimidad del menor, el contacto y la comunicación sin restricciones con la familia y con el abogado defensor. (Naciones Unidas, 1990).

Es necesario mencionar el propósito del uso de la fuerza, si bien es permitido por este reglamento, no significa que la violencia está permitida, mucho menos se entiende que su "uso" es necesario o constante. La fuerza se debe emplear solo para repeler un ataque o daño certero, para evitar daños en la integridad de algún menor, para proteger al grupo. El ánimo de esta norma no mantiene el elemento educativo o necesario para lograr la resocialización, más bien, explica que el empleo extraordinario de la fuerza no debe causar humillaciones o daños.

K. Limitaciones de la coerción física y del uso de la fuerza: Sólo podrá hacerse uso de la fuerza o de instrumentos de coerción en casos excepcionales, cuando se hayan agotado y hayan fracasado todos los demás medios de control y sólo de la forma expresamente autorizada y descrita por una ley o un reglamento. Esos instrumentos no deberán causar humillación ni degradación y deberán emplearse de forma restrictiva y sólo por el lapso estrictamente necesario" (Naciones Unidas, 1990).

El uso de la fuerza no es parte del programa resocializador, sirve como medida para contener un ataque o daño certero.

Finalmente, resulta necesario (al terminar la medida socio-educativa de internamiento) implementar un programa de trabajo que elimine el contacto diferencial y de esa manera se reduzcan los factores de riesgo que circundan al menor. En ese sentido, se debe de tener en cuenta 
que la mayoría de los infractores encerrados cometieron un detrimento en el patrimonio de otra persona o bien el fundamento o motivo de sus actos fueron el dinero. En ese sentido, si los menores ingresan a trabajar luego de salir del penal, podrán cubrir sus necesidades básicas y por sobre todo salir del ambiente nocivo que representa volver al barrio u hogar que los arrastró al mundo criminal. El éxito del programa resocializador se puede eliminar cuando el menor retorna al origen (factor de riesgo) que determinó su perfil criminal. "N. Reintegración en la comunidad. Todos los menores deberán beneficiarse de medidas concebidas para ayudarles a reintegrarse en la sociedad, la vida familiar y la educación o el trabajo después de ser puestos en libertad" (Naciones Unidas, 1990).

\section{4.- Normas Administrativas en los Centros Juveniles de Diagnóstico y Rehabilitación de Medio Cerrado}

El propósito del siguiente subtítulo es relacionar y analizar las implicancias entre lo desarrollado en este capítulo con el Principio de Legalidad en la Ley Penal y las disposiciones Administrativas ejercidas por los Centros de Diagnóstico y Rehabilitación a nivel nacional. Por ello, se analizarán los puntos más relevantes de las Resoluciones Administrativas que también delimitan el campo de estudio de este trabajo.

\subsection{1.- Reglamento de Derechos, Deberes y Sanciones de los Adolescentes en Conflicto con la Ley Penal de los Centros Juveniles de Medio Cerrado del Poder Judicial}

\section{a) Sobre los derechos}

La sección de Derechos establece una recapitulación de los Derechos Constitucionales e instrumentos internacionales que el Perú ha ratificado (artículo 5 del Reglamento). Se debe resaltar el respeto por la integridad física, psicológica, moral y el trato digno -inherente a la persona humana-. Ello incluye una infraestructura adecuada de servicios higiénicos operativos y en buenas condiciones; se debe tener en cuenta que la sobrepoblación genera un caos generalizado en el uso de los servicios higiénicos que son utilizados en ciertas horas del día y tienen un aforo restringido y limitativo. (literal a y c del artículo 5 del Reglamento).

La misma sección, en el literal h, incluye que los menores deben recibir una atención médica, psicológica y social con la finalidad de mantener o mejorar su salud. Frente a ello, es difícil imaginar la eficacia de este derecho en un ambiente de hacinamiento. 
En otro orden de ideas, los deberes desarrollados en el Capítulo dos del comentado Reglamento, establece los fundamentos por los cuales se debe llevar a cabo el Sistema de Resocialización Social: la razón, la fe, y el afecto (artículo 6, literal a). A propósito, y en sintonía con la Constitución, se determinó que el Estado es independiente de toda creencia religiosa; además, las máximas morales (que suponen una independencia de la autoridad divina) guiadas por la razón, demuestran que bajo un ambiente de hacinamiento no es posible efectuar de manera óptima el plan de educación y resocialización, que la violencia afecta al diálogo y enseñanza, más bien, alimenta el descontrol y la venganza. Los reglamentos suponen el desarrollo de las ideas determinadas en una norma antecedente, sin embargo, la descripción de estos conceptos queda en suspenso altivo.

\section{b) Sobre los deberes}

El apartado b del artículo 6 del mismo Reglamento, proporciona una opción para el menor sujeto al internamiento, cito: "b. Obedecer al personal, siempre y cuando dichas órdenes no sean puestas a sus derechos y obligaciones establecidas en los documentos de gestión." Es decir, si existe una vulneración expresa a un derecho, el menor puede incumplir una decisión administrativa ¿es una vulneración a su derecho a la integridad física, psicológica y moral el castigo generado en el Programa de Intervención Intensiva?

Este Reglamento permite de igual modo identificar la vulneración que ocasiona la fuga de un menor de un Centro Juvenil. El apartado “ $\mathrm{j}$ ” del artículo 6 del mismo Reglamento, determina un deber: permanecer en el Centro Juvenil hasta que exista una orden de externamiento suscrita por un Juez. Por consiguiente, cada vez que un adolescente fuga, contraviene el deber expreso de permanecer en el Centro Juvenil hasta que una orden judicial determine el cese de la medida. Esta es la razón detrás de la recaptura, del nuevo encierro, extralimitaciones de castigo y consecuentes daños físicos, psíquicos y morales.

\section{c) De las faltas, sanciones y aplicación}

El artículo 7 determina que las faltas leves, graves y muy graves serán sancionadas sin perjuicio de la ley penal, se encuentra además que la acumulación de faltas leves (remangar el buzo de deporte a la altura de la rodilla, apartado $\mathrm{k} \mathrm{del}$ artículo 7) genera una falta grave (arrojar alimentos, 
desperdicios, escupir, etc. $)^{14}$ Del mismo modo, la reiteración de faltas graves genera una falta muy grave.

El sistema de sanción escala por acumulación e intensidad, solo hace falta la doble comisión de una falta leve para convertirla en grave; en este contexto la norma administrativa utiliza la palabra "Reincidencia", según la RAE la reincidencia es la "reiteración de una misma culpa o defecto" (RAE, 2017), es decir volver a hacer o decir algo. Por tanto, con solo repetir la acción una vez más, el menor que comete una falta leve, deberá afrontar una sanción entendida como grave o muy grave según el nivel de repeticiones; a mayor repetición, mayor intensidad de la sanción, no importando la naturaleza de la misma, en algunos casos solo son relevantes las repeticiones.

Ahora bien, el punto 7.3 que desarrolla el punto de las faltas muy graves. Es menester comentar los apartados "g" e "i" que determinan lo siguiente: g. Liderar, alentar o participar en reyertas, motines, fugas y sublevación en contra de la autoridad o intento de ello. i. Intento o fuga cuando sea trasladado al exterior para alguna diligencia y/o actividad. Existe, por tanto, dos prohibiciones expresas hacia la fuga; pese a que la ley penal no la considera como conducta típica, la norma administrativa sanciona empeorando la medida socio educativa, llevando a los menores que fugan al Programa de Intervención Intensiva. La intención de la administración es lograr la permanencia constante en el Centro Juvenil hasta que exista una orden de externamiento suscrita por un Juez; para ello, creó una norma que lo faculta a capturar, encerrar y castigar. Lo concerniente a este tema será abordado en el capítulo quinto, numeral 5.5 que desarrolla el tema del principio de Legalidad de la norma penal.

En la norma administrativa se encuentra el Capítulo II "De las sanciones disciplinarias". En aquel apartado se determina que la administración busca generar "experiencias educativas" para que a través de ellas, el adolescente pueda recapacitar sobre la indisciplina cometida (artículo 8). Una de estas experiencias educativas resulta la premisa en el apartado "h. Traslado de ambiente o Programa; ingreso al Programa de Intervención Intensiva". Muy cerca a esta disposición, el artículo 9 define que: "El ingreso al Programa de Intervención Intensiva no será menor a un mes ni mayor de tres meses. Se aplica solo cuando el adolescente presenta alguna de las faltas tipificadas como muy graves".

${ }^{14}$ El uso del "etcétera" dentro de una norma administrativa genera inseguridad jurídica. 
La preocupación por generar algún daño en la salud física o psicológica en la persona está mostrada por el artículo 11 "Las experiencias educativas pueden ser suspendidas cuando el adolescente presenta serias alteraciones en su salud física o mental”. Cabe la pregunta ¿por qué dichas "experiencias educativas" pueden generar serias alteraciones en la salud del adolescente? Se supone que estas experiencias educativas se desempeñan en respeto a la salud, dignidad e integridad de los menores. Así lo explica el artículo 13: "Ningún adolescente está sujeto a sanciones disciplinarias que constituyan un trato cruel, inhumano o degradante. Quedan prohibidos los castigos corporales, el aislamiento absoluto o la reducción de alimentos, y no se deberá sancionar más de una vez por la misma falta disciplinaria".

En tal consideración el Capítulo III en el artículo 15, explica que la imposición de la sanción tendrá en cuenta la naturaleza de la falta “(...), la gravedad del comportamiento, su responsabilidad, el grado de participación, sus características de personalidad, la confesión sincera y la reparación espontánea del daño que podría haber generado". Si este numeral se aplicara, se entendería que la naturaleza de la fuga sin violencia no se podría relacionar con una falta muy grave, toda vez que es el propio encierro el que ocasiona el anhelo de obtener libertad; es claro que la libertad ha sido y es inherente a la condición humana.

En las normas generales de la Directiva N`5-2007-GG-PJ "Normas y procedimientos a seguir en situaciones de fuga de los adolescentes infractores de los centros juveniles a nivel nacional" se ha establecido que: 6.1. Los Centros Juveniles a nivel nacional albergan adolescentes por mandato judicial, quienes por la situación en la que se encuentran pueden reaccionar negativamente a la medida de internamiento y medida del Sistema de Reinserción Social del Adolescente Infractor (SRSAI) prevea en algún caso, provocando, entre otros casos, una situación de fuga".

Finalmente, este Reglamento de derechos, deberes y sanciones establece el límite para el empleo de la fuerza: "Artículo 26. Los Educadores Sociales u otras autoridades del Centro Juvenil, no podrán hacer uso de la fuerza física a excepción de casos que impliquen peligro para su integridad física y de otras personas". El empleo de la palabra peligro asigna una cuota de incertidumbre, ya que es un concepto vago que encierra connotaciones subjetivas, propias de la experiencia y concepción personal. Tanto que algún Educador Social u otra autoridad puede entender que la fuga sin violencia de un adolescente que cumple una medida socio-educativa por hurtar un celular, es un acto de peligro, ya que podría seguir hurtando celulares en las calles de la 
ciudad; en cambio, para otro, el juicio de valor puede ser distinto, y no encontrará motivos para encerrar o volver a encerrar a alguien que cometió la sustracción no violenta de un teléfono celular.

\section{d) Respecto a la peligrosidad}

El concepto de peligrosidad es definido por cada sociedad, de manera variable y subjetiva. Es también una atribución que desarrolla el grupo dominante para subyugar a una minoría; inferior, desprotegida y sin poder (Foucault, 2015). Las recientes experiencias venezolanas de represión a la protesta ciudadana política es un referente claro (Meza, 2017). Asimismo, es una manera de discriminación ya que responde a prejuicios: un hombre/mujer de etnia diferente, tatuajes o marcas en la piel, una vestimenta sucia y desordenada, pueden dar lugar a prejuicios ¿qué es peligroso hoy?

La homosexualidad era "peligrosa" en la Inglaterra del siglo pasado, se debía detener y desincentivar su práctica. Ello ocasionó que la específica conducta sexual sea tipificada como un delito y mereciera una condena; la imposición de una medida de seguridad con una cuota intensiva de fármacos formaba parte de la sentencia más benévola de la época.

En adición, para cada sentencia existe un juicio intrínseco de peligrosidad:

En la doctrina italiana FERRAJOLI ha denunciado que el principio de taxatividad de las medidas y de sus presupuestos queda negado en todos los casos por el hecho de que la elección del tipo de medidas y, en ocasiones, la propia decisión sobre la oportunidad de aplicarla quedan confiadas al juicio de peligrosidad, que, por naturaleza, no se vincula a hechos predeterminados sino a una valoración del juez puramente discrecional, además, ni siquiera la duración de la medida de seguridad está predeterminada legalmente ni determinada definitivamente en la resolución sobre su aplicación.

(De Vicente Martínez, 2004, p.781).

\subsection{2.- Normas y Procedimientos a Seguir en Situaciones de Fuga de los Adolescentes Infractores de los Centros Juveniles a Nivel Nacional}

La Resolución Administrativa de la Gerencia General del Poder Judicial N 369-2007-GG-PJ, de fecha 15 de junio de 2007, aprobó la Directiva Nº5-2007-GG-PJ denominada "Normas y Procedimientos a Seguir en Situaciones de Fuga de los Adolescentes Infractores de los Centros Juveniles a Nivel Nacional.”

El procedimiento en caso de fuga puede ser resumido en 4 aspectos:

- Comunicación con la Fiscalía de turno y con la Policía Nacional.

- Informe, bajo responsabilidad, del Educador Social encargado. 
- Oficio con Informe, dirigido a la Fiscalía de Familia de Turno, Fiscalía Penal de Turno, Juzgado de origen y al Gerente de Centros Juveniles.

- La Policía Nacional hará la búsqueda inmediata del adolescente infractor.

En suma, la Dirección del Centro Juvenil solicitará información relevante para elaborar un Informe Final, que presentará a la Gerencia de Centros Juveniles con la descripción e identificación de las causales de la fuga, el grado de responsabilidad del personal y las acciones o medidas a implementarse. Por consiguiente, es la Dirección del Centro Juvenil quien determina la sanción al adolescente que escapa del Centro Juvenil; será ella la encargada de observar que la conducta fuga no alberga un comportamiento ilícito -y como falta administrativa- deberá haber una recaptura, pero no un castigo que implique el uso de la fuerza, tampoco un aislamiento que propone el daño psíquico o físico.

\subsection{3.- Manual de Seguridad Integral al interior de los Centros Juveniles de Medio Cerrado a nivel Nacional}

Mediante Resolución Administrativa de la Gerencia General del Poder Judicial No 207-2014-GGPP, de fecha 24 de abril del 2014, se aprobó el Manual de Seguridad Integral al interior de los Centros Juveniles de Medio Cerrado a nivel Nacional. El punto de interés está desarrollado en el Capítulo IV Seguridad por Contingencias (4.5 En caso de Situaciones de Fuga). En primer término, se resumirán algunas de las directivas, para finalmente englobar el ánimo de la Administración y detectar sus propensiones y mecanismos. Así también, se puede encontrar vestigios del tema principal de estudio en otro ámbito en el punto 2.7 (Del Agente de Protección Interna -API-), en que se entiende que la fuga siempre implica una situación de violencia.

La violencia no es una condición constante o propia de las fugas; es posible, escapar sin el uso de la fuerza o la ocurrencia de daños. Por consiguiente, no se puede afirmar que una fuga siempre presentará un escenario violento; el equivocado concepto niega la materialización de una oportunidad. "2.7.4 Prevenir y repeler en coordinación con la Policía Nacional del Perú (PNP), y cuando el caso lo amerite, cualquier tipo de acción violenta al Centro Juvenil (secuestro, motín, reyerta, intento de fuga, etc.); y en caso se evidencie actos sospechosos en el perímetro externo (presencia de vehículos, acumulación de personas, entre otros) deberá realizar coordinaciones con la PNP." (Gerencia General del Poder Judicial, 2014). 
Los menores fugados, rara vez albergarán el propósito de desafío a la autoridad; la acción es guiada por el instinto de libertad. Es un acto reflejo, propio de la condición duradera del encierro (basta quedarse atrapado en un ascensor para sentir la desesperación por encontrar una salida).

En este Manual, la administración detecta que en ciertas fechas del año (4.2 Fechas especiales: Día de la Madre, del Padre, Fiestas Patrias, Navidad, Año nuevo, etc.) la Administración reconoce que los menores experimentarán emociones de angustia, tristeza, depresión y que ello a su vez incrementa la posibilidad de fuga. No obstante, en lugar de brindar más visitas y actividades que incluyan a familias o amigos de los menores infractores, se implanta medidas de seguridad perimetral interna y externa.

En el punto 4.6 "En caso de situaciones de fuga", se establece la comunicación y funciones de la administración. Por ello, en caso de fuga, la situación se debe comunicar de manera inmediata a la Policía del Perú y a la Fiscalía de Turno. Siendo la Fiscalía la única persecutora del delito, debe investigar si en la acción fuga medió violencia, y si se dañó o no algún bien jurídico protegido.

Como ya se desarrolló, la ley penal no castiga la conducta de evasión no violenta; por tanto, tampoco castiga el escape de un medio cerrado, sin violencia o daños a personas (a otros internos o educadores). En cambio, si la evasión ocasiona el detrimento de un bien jurídico protegido, entonces será necesaria la actividad complementaria del Fiscal, que investigará el hecho para concuasar la conducta en un tipo penal.

Asimismo, la autoridad Administrativa, solicita a la Policía del Perú que el menor fugado sea aprehendido a la brevedad posible (4.6.4). El art. 2, inc.20 apartado g, primera parte de la Constitución reconoce, de un lado, a toda persona el derecho a la libertad y seguridad personales y, de otro lado, establece la excepción a esta regla: Nadie puede ser detenido sino por mandamiento escrito y motivado del juez o por las autoridades policiales en flagrante delito. Se trata de un mandato administrativo (el contenido en el 4.6.4) inconstitucional, por tanto inválido.

"En todo caso el detenido debe ser puesto, dentro de las veinticuatro horas o en el término de la distancia, a disposición del Juzgado que corresponde" (Sánchez Velarde, s.f., p.59). Hoy 48 horas según Ley 30558 del 8 mayo de 2017. Sin embargo, la comunicación que realiza el Centro Juvenil, no se respalda en una detención judicial con el propósito de emitir una orden de detención, sino más bien recurre al Fiscal y a la Policía; para que ambos ejecuten el pedido de aprehensión y limitación de la libertad. 
El director del Centro Juvenil, está autorizado para oficiar a la Policía el pedido de aprehensión inmediata (punto 4.6.4 del Manual). La justificación circunda la posición que el menor fugado estaba cumpliendo una orden judicial y está obligado a cumplirla. Esta tesis admite que la medida socio-educativa deba cumplirse en su totalidad, amparada en los criterios de necesidad, utilidad y eficacia. Pero es notable que hay características nocivas en el encierro juvenil.

En consecuencia, la norma administrativa contenida en el punto 4.6 .4 del manual contraviene el mandato constitucional de detención; toda vez que en un caso de evasión del medio cerrado, se solicita y autoriza a la Policía detener al adolescente fugado sin una orden judicial expresa y sin flagrancia.

Además, el retorno al Centro Juvenil no puede incluir un castigo corporal ni sufrimiento psicológico. Actualmente ocurre, que el menor que escapa será reprendido y sancionado por la administración de aquel Centro. Luego del castigo corporal -guiado por una distorsionada idea de prevención-, el menor será enviado a un espacio definido como Programa de Intervención Intensiva, en que quedará aislado por lo menos un mes (máximo, tres meses).

\section{a) Programa de Intervención Intensiva}

El Programa de Intervención Intensiva del Centro Juvenil para mujeres, coloca a las menores en habitaciones muy pequeñas, sin ventanas, con una cama de cemento, sin baño, con un pequeño ducto de aire y donde las relaciones interpersonales son mínimas.

Reciben la visita de una educadora por media hora al día y a la semana-dependiendo de su comportamiento abnegado- merecerá la visita de un familiar por una hora; el tiempo que pasará la menor en esta condición será un mes como mínimo, tres como máximo.

En el caso del Centro Juvenil de Diagnóstico y Rehabilitación de Lima (Maranguita) se constató mediante la visita realizada el año 2017, que son menos de 20 adolescentes los que habitan en un solo ambiente, una reja de barras los aleja de los educadores que duermen y se encuentran en lugares distintos. El propósito para estos ambientes es el castigo y el aislamiento del adolescente que contraviene las normas internas del centro juvenil.

En la visita realizada por el autor de la investigación se denegó el ingreso al "PII Cielo", un ambiente de castigo severo donde presuntamente se inflige dolores graves físicos y psicológicos a los adolescentes infractores. Aquel espacio se encontraría en la parte más alta del Centro Juvenil para adolescentes hombres, encima de las oficinas administrativas; el personal del lugar dijo que 
dicho ambiente existía y que era utilizado como medio de castigo, no obstante, se negaron a mostrar aquellas instalaciones y afirmaron que dicho ambiente se convirtió en un almacén. No existe certeza que el Programa de Intervención Intensiva Cielo ya no se encuentre operativo.

\section{b) Periodo de eficiencia}

En una entrevista con una ex funcionaria de alto rango del Centro Juvenil de Santa Margarita (noviembre 2016), se afirmó que cada Programa (de los 4 existentes) tiene en promedio una duración de 6 meses. Es decir, transcurridos dos años de la medida socio-educativa, la administración de aquellos centros se ve obligada a repetir los talleres, actividades, clases educativas, entrevistas, etc.; una rutina cíclica que también genera resultados contraproducentes.

Ella consideraba que esta situación generaba un problema adicional, debido a que incrementaba el estrés de las menores en encierro. Explicaba que la primera vez que la menor era enviada a uno de los cuatro programas de rehabilitación y diagnóstico, existía en principio la curiosidad, incluso emoción de hacer una actividad distinta, completamente nueva. No obstante, existe el efecto colateral que albergan las largas medidas socio-educativas, ya que estos problemas mantienen ciertos márgenes en la educación que deben impartir a las jóvenes. Los programas se ven forzados a repetir el mismo taller, a repasar los conceptos conocidos y aprendidos por las jóvenes.

Ello causa en las menores una progresiva pérdida de atención e interés en las materias enseñadas; además, se incrementa el nivel de estrés, ergo, el propósito resocializador se ve afectado. En aquel contexto, la agresividad aumenta y la acumulación de faltas leves, generará faltas graves y estas a su vez, generarán que la joven repita una y otra vez los programas de los que ya aprendió lo necesario. Así también, las faltas muy graves serán castigadas con la aplicación del Programa de Intervención Intensiva.

En suma, este periodo de eficiencia dura en promedio dos años; no obstante, los jueces y juezas cuentan con la posibilidad de dictar medidas de internamiento superior a los dos años.

\section{5.- Código de Responsabilidad Penal de Adolescentes}

El Decreto Legislativo Nº1348 aprueba el Código de Responsabilidad Penal de Adolescentes el día 6 de enero del 2017. 
Los adolescentes iure et de iure no poseen responsabilidad penal, por lo que el título de la presente norma es objetable. El análisis de esta norma, que mantiene de manera preponderante un carácter procesal, será desarrollado en el Capítulo VI y Capítulo VII de la presente investigación.

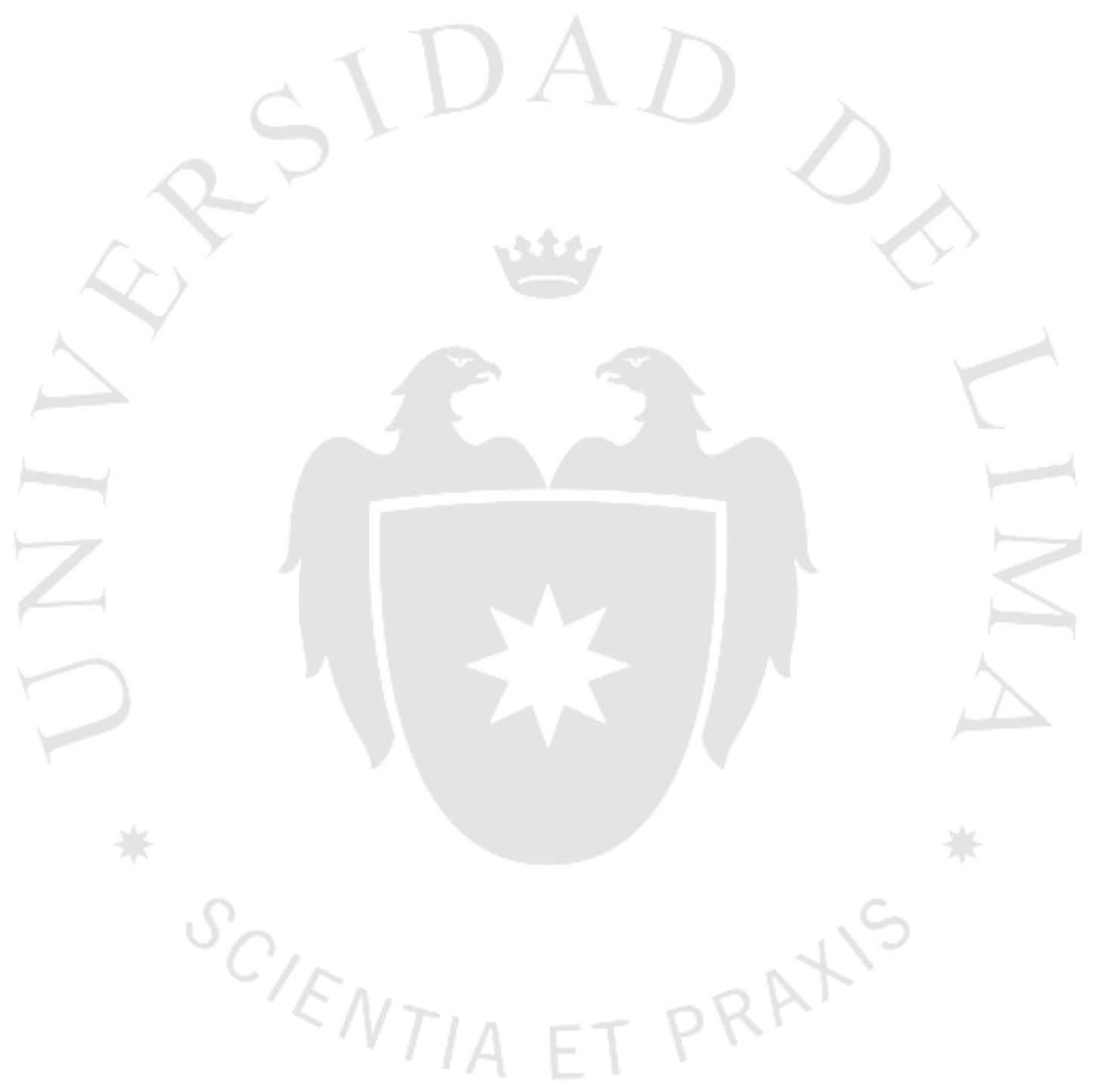




\title{
CAPÍTULO IV: COMPORTAMIENTO LEGISLATIVO Y PANORAMA JURISDICCIONAL
}

\author{
“(...) un buen legislador pensará menos en castigar los \\ crímenes que en evitarlos, se ocupará más en morigerar \\ que en imponer suplicios. Es una observación perpetua de \\ los autores chinos que, en su imperio, cuanto más se \\ aumentan los suplicios, más cerca está la revolución. Fácil \\ me sería probar que en todos o casi todos los Estados \\ europeos las penas han disminuido o aumentado a medida \\ que se está más cerca o lejos de la libertad". \\ (Montesquieu, 1990, p.57).
}

\section{1.- Consecuencias de la desproporción penal}

El Código Penal desde la década del año 1990 ha sufrido muchas variaciones, fueron incorporados algunos comportamientos criminales y, creyendo que así se solucionaría el problema, también se elevaron las penas. Una mutación general en los delitos más reportados por la prensa de la época (secuestros, violaciones sexuales y asaltos a mano armada).

En aquel momento tipos penales como robo, secuestro, homicidio, asesinato, ya existían. Todos ellos, diferentes, cada uno con un tipo penal definido e independiente. Sin embargo, los actos delictivos que se cometían combinaban conductas, y en lugar de aplicar las bases del concurso real de delitos, los legisladores decidieron modificar el código penal. Hicieron una ley más dura y alejada de toda visión de eficiencia. En consecuencia, la independencia entre los tipos penales se perdió y esta mutación generó una desproporción en las penas.

En efecto, el tipo penal del robo, determinaba una pena superior a 3 años, el límite de condena como máximo era de 8 años de pena privativa de libertad. Después de la intervención del legislador, la misma conducta delictiva es castigada con una pena mínima de 8 años y máxima de 10 años. Es decir, "el básico" se incrementó de manera desmedida (266.6\%). Asimismo, se incluyeron y mezclaron distintos bienes jurídicos en un solo tipo penal, creando confusión a la hora de castigar y generó incoherencia en el tiempo abstracto de punición de la pena privativa de libertad. 


\subsection{1) Medidas socio educativas más severas}

Para obtener un panorama completo debemos observar los castigos impuestos a los menores que mantienen -o mantuvieron- una medida socio educativa. La Administración de los Centros Juveniles de Diagnóstico y Rehabilitación facilitó la información del año 2015, ello permite determinar el grado en el que la desproporción penitenciaria afectó a la administración de castigos. Recordemos, el Derecho Penal es fragmentario y subsidiario, de ultima ratio y no es necesario encerrar a personas ni menores que puedan sustituir el bien dañado (o arrebatado).

¿Representa alto peligro aquel menor que infringe la ley penal por hurtar un bien de naturaleza patrimonial (sustracción no violenta)? Para responder esta pregunta observaremos unos cuadros facilitados por la administración de los Centros Juveniles, ello ayudará a descifrar un atisbo del síntoma criminal de nuestro país.

Tabla 4.1.

Motivo de ingreso de los adolescentes infractores a los Centros Juveniles a nivel nacional

\begin{tabular}{|c|c|c|c|c|c|c|c|c|c|c|c|}
\hline \multicolumn{10}{|c|}{ MOTIVO DE INGRESO DE LOS ADOLESCENTES INFRACTORES A LOS CENTROS JUVENILES A NIVEL NACIONAL. MEDIO CERRADO } & \multicolumn{2}{|c|}{ TOTAL } \\
\hline MATERIA // CJRD & LIMA & $\begin{array}{c}\text { SANTA } \\
\text { MARGARITA }\end{array}$ & $\begin{array}{c}\text { ALFONSO } \\
\text { UGARTE }\end{array}$ & \begin{tabular}{|c|} 
JOSÉ \\
QUIÑNONES \\
GONZALES
\end{tabular} & MARCAVALLE & EL TAMBO & $\begin{array}{c}\text { MIGUEL } \\
\text { GRAU }\end{array}$ & PUCALLPA & TRUJILLO & TOTAL & $\%$ \\
\hline Robo - Robo agravado & 497 & 29 & 32 & 43 & 36 & 61 & 53 & 69 & 69 & 889 & 47.6 \\
\hline Violación sexual & 110 & 0 & 26 & 31 & 33 & 50 & 28 & 27 & 24 & 329 & 17.6 \\
\hline Hurto (variantes) & 47 & 6 & 8 & 25 & 32 & 22 & 11 & 32 & 4 & 187 & 10 \\
\hline Homicidio (variantes) & 77 & 12 & 15 & 14 & 9 & 23 & 13 & 2 & 16 & 181 & 9.7 \\
\hline Tráfico Ilicito de Drogas & 43 & 6 & 8 & 4 & 4 & 9 & 6 & 8 & 3 & 91 & 4.9 \\
\hline Tenencia Ilegal de Armas & 36 & 2 & 0 & 4 & 0 & 1 & 4 & 1 & 18 & 66 & 3.5 \\
\hline Otros & 10 & 4 & 1 & 7 & 2 & 0 & 2 & 7 & 33 & 66 & 3.5 \\
\hline Lesiones (variantes) & 14 & 2 & 3 & 4 & 15 & 7 & 3 & 3 & 1 & 52 & 2.8 \\
\hline Pandillaje & 4 & 0 & 0 & 0 & 0 & 1 & 0 & 0 & 0 & 5 & 0.3 \\
\hline Secuestro & 2 & 0 & 0 & 1 & 0 & 0 & 0 & 0 & 0 & 3 & 0.2 \\
\hline TOTAL & 840 & 61 & 93 & 133 & 131 & 174 & 120 & 149 & 168 & 1869 & 100 \\
\hline
\end{tabular}

"Comentario: La materia de infracción con mayor porcentaje de incidencia, es Robo - Robo agravado que representa el $47 \%$ del total de población atendida, seguida de violación sexual con un $18 \%$ y en tercer lugar Hurto (variantes) con $10 \%$."

Fuente: Elaborado por Poder Judicial. (2015). Motivo de ingreso de los adolescentes infractores a los Centros Juveniles a nivel nacional. Medio cerrado. Elaborado por la Administración de los Centros Juveniles de Medio Cerrado.

En el gráfico se evidencia el motivo que mantiene en la modalidad de Medio Cerrado a menores y mayores en los distintos Centros Juveniles. Observamos que la infracción más castigada por los jueces y juezas es el robo simple y robo agravado (ambos en una misma categoría), en un segundo lugar está la violación sexual, y en el tercer lugar encontramos al hurto. A estos tres principales, continúa el homicidio, el tráfico ilícito de drogas, posesión indebida de armas, lesiones, pandillaje y secuestro. 
Cuando la ley pretende ir más allá o servir a intereses distintos deja de ser garantía de la libertad y se transforma en una amenaza para la misma; "cuando las leyes limitan la conducta de los ciudadanos más de lo que exige la pública conservación, cuando convierten en delito las acciones indiferentes, entonces directamente las leyes oprimen la libertad.

(Pagano, 1968, p.1196).

Es necesario hacer una pausa y reflexionar sobre estos datos, casi la mitad de todos los menores que cumplen una medida socio-educativa son aquellos que cometieron robos o robos agravados. Es decir, quizá realizaron su actividad criminal en pluralidad o grupo (2 o más personas), de noche, tal vez emplearon alguna herramienta/arma para amedrentar, o quizá utilizaron violencia, pero no dañaron bienes jurídicos como la vida o la salud: no lo podemos saber. Resulta necesario establecer una diferencia entre los robos y los robos agravados, más allá de la etiqueta legislativa, es más importante saber qué bienes jurídicos protegidos se vulneraron ¿Cuál es el bien jurídico que soportó el detrimento? Responder esta pregunta es relevante ya que será posible establecer si el castigo o la medida socio educativa es severa y resulta necesaria, toda vez que hay un estado de hacinamiento en medios cerrados. Los menores infractores que dañan patrimonio necesitan primero educación y trabajo, no un ambiente que los obliga a mimetizarse con sicarios.

Los infractores que cometieron hurto (y sus variantes) vulneraron un riesgo prohibido, se beneficiaron con patrimonio, no obstante, el daño ocasionado (elemento motivador del internamiento en medio cerrado) no es grave. Pese a ello, los jóvenes que cometieron hurto son colocados en estos grupos donde - cabe la posibilidad- de que sean utilizados por los más experimentados y agresivos; que aprovechan de su influencia y fuerza para lograr el control y manipulación de los menos fuertes y experimentados.

Es necesario recordar que la desproporción entre los delitos y castigos que existe en el Código Penal no elimina la reincidencia o disuade conductas criminales; lo que sí ocasiona es el favorecimiento de los conocimientos delictivos en la justicia de menores.

(...) En ese sentido, por ejemplo en la República Argentina, se han precipitado repentinamente una andanada de leyes que tuvieron como corolario el endurecimiento punitivo, para dar paso a una expansión desmesurada de la legislación penal. Es decir, puede afirmarse, de acuerdo al devenir legislativo argentino en materia penal, que la gran mayoría de las modificaciones introducidas importan un endurecimiento del proceso penal. Asimismo, haciendo una indagación sobre el tratamiento parlamentario de muchas de esas reformas legislativas, se puede advertir algo recurrente: su origen inmediato no es más que un proceso de interpretación, por parte de la dirigencia política, de algo que reclama la opinión pública. Al respecto, y no obstante que bien puede ser considerado como un objetivo noble que el Estado esté atento a lo que percibe de la 
demanda social, esto no implica acoger acríticamente cualquier petición relacionada con tales cuestiones, que incluso son retroalimentadas en términos populistas. Se desprende de todo ello que la política criminal y de seguridad de un país no puede ser resultado de reacciones emocionales o espasmódicas. Estas políticas no pueden diseñarse sobre la base de encuestas de la televisión. No se trata de decir lo que la gente quiere escuchar. Cien mil o un millón de firmas no puede neutralizar la necesidad de advertir sobre las falsas recetas. Porque no es la primera vez que frente al aumento de los delitos y el impacto de algunos crímenes aberrantes se postula como correlato la necesidad de incrementar la violencia, de aumentarlas penas, reducir el límite de edad para los menores, o conceder más facultades policiales.

(Zaffaroni, 2012, p.95).

En consecuencia, si la conducta delictiva del menor infractor afecta solamente la libre disposición de patrimonio, no resulta eficiente una medida de encierro y posterior convivencia criminal; existe la alternativa de utilizar los recursos otorgados por la Justicia Restaurativa. "Se dirá que un acto es socialmente indeseable, si los beneficios sociales esperados son superados por el daño esperado. Así, ciertamente, donde los beneficios sociales son cero, un acto potencialmente dañino será socialmente indeseable. Sin embargo, donde los beneficios sociales esperados son positivos, un acto se considerará indeseable dependiendo de la comparación con el daño esperado. Así podría ser deseable para una persona rebasar el límite de velocidad para llegar al hospital en un caso de urgencia, pues los beneficios sociales esperados serían mayores que el daño esperado, (...)" (Shavell, 2000, p.439).

Se considera que esta lógica de castigo se debe mantener con la finalidad de evitar la pérdida del efecto disuasivo que debería tener la norma penal; si todo es castigado con una condena efectiva, entonces se puede hacer todo, ya que acarrea el mismo resultado, el riesgo es similar. "En primer lugar, no debe en modo alguno creerse que el daño o riesgo de daño a los intereses de los demás, única cosa que justifica la intervención de la sociedad, lo justifica siempre" (Stuart Mill, 2013, p.209).

\subsection{2) Medidas socio educativas más largas}

Un efecto que se escinde del manejo deliberado en la proporción de las penas es el tiempo, dimensión o duración de la condena. En efecto, existe una relación entre en tiempo y la experiencia de estos infractores penales, ya que el periodo de la medida socio educativa será utilizada y servirá para mimetizar posturas, aprender el manejo de armas, vías óptimas para el tráfico de drogas, etc. Es decir, se facilita el conocimiento criminal pues todos los contactos que "el mercado criminal" ofrece se encuentran centralizados en las prisiones y en los centros juveniles. Todos los menores 
se relacionarán, de manera optativa y algunos de forma impuesta (los lugares que muestran mayor hacinamiento acarrean que dos personas duerman en una sola cama), facilitan los contactos necesarios para obtener "mayores ganancias y mejores trabajos". A todas luces, también se implementa de hecho en este medio el sistema denominado networking ${ }^{15}$, más eficaz, veloz, constante, pero riesgoso para la sociedad.

Exámenes clínicos realizados mediante los clásicos test de personalidad han mostrado los efecto negativos del encarcelamiento sobre la psique de los condenados y la correlación de estos efectos con la duración de éste. Los estudios de este género concluyen que "la posibilidad de transformar un delincuente violento asocial en un individuo adaptable a través de una larga pena carcelaria no parece existir", y que "el instituto penal no puede realizar su objetivo como institución educativa". El régimen de "privaciones" tiene efectos negativos sobre la personalidad y contrario al fin educativo del tratamiento, (...).

(Baratta, 2004, p.194).

Por esta razón, se presentarán cuadros que evidencian el tiempo que los menores criminales promedio comparten con otros menores sicarios, violadores sexuales y traficantes de droga.

Tabla 4.2

Duración de la Medida Impuesta (medio cerrado)

\begin{tabular}{|c|c|c|c|c|c|c|c|c|c|c|c|}
\hline \multicolumn{10}{|c|}{ DURACIÓN DE LA MEDIDA IMPUESTA (MEDIO CERRADO) } & \multicolumn{2}{|c|}{ TOTAL } \\
\hline TIEMPO // CJRD & LIMA & $\begin{array}{c}\text { SANTA } \\
\text { MARGARI } \\
\text { TA }\end{array}$ & $\begin{array}{l}\text { ALFONSO } \\
\text { UGARTE }\end{array}$ & \begin{tabular}{|c} 
JOSÉ \\
QUIÑONES \\
GONZALE \\
S
\end{tabular} & $\begin{array}{c}\text { MARCAVA } \\
\text { LLE }\end{array}$ & EL TAMBO & $\begin{array}{c}\text { MIGUEL } \\
\text { GRAU }\end{array}$ & PUCALLPA & TRUJILLO & TOTAL & $\%$ \\
\hline De 1 a 30 dias & 0 & 0 & 0 & 0 & 0 & 0 & 0 & 0 & 0 & 0 & 0 \\
\hline De 1 a 6 meses & 30 & 2 & 2 & 1 & 3 & 7 & 0 & 2 & 0 & 49 & 11.5 \\
\hline De 7 a 12 meses & 205 & 16 & 12 & 21 & 20 & 23 & 17 & 41 & 22 & 377 & 88.5 \\
\hline TOTAL & 235 & 18 & 14 & 22 & 23 & 30 & 17 & 43 & 24 & 426 & 100 \\
\hline De 13 a 18 meses & 122 & 8 & 6 & 11 & 13 & 9 & 13 & 31 & 17 & 230 & 15.9 \\
\hline De 19 a 24 meses & 127 & 4 & 15 & 32 & 16 & 17 & 22 & 22 & 34 & 289 & 20 \\
\hline De 25 a 30 meses & 33 & 1 & 3 & 4 & 1 & 5 & 6 & 7 & 8 & 68 & 4.7 \\
\hline De 31 a 36 meses & 84 & 7 & 18 & 13 & 13 & 28 & 19 & 10 & 29 & 221 & 15.3 \\
\hline De 37 a 42 meses & 10 & 1 & 2 & 2 & 1 & 3 & 1 & 2 & 0 & 22 & 1.5 \\
\hline De 43 a 54 meses & 54 & 5 & 6 & 14 & 14 & 23 & 12 & 8 & 17 & 153 & 10.6 \\
\hline Por 5 años & 45 & 3 & 9 & 7 & 12 & 18 & 9 & 10 & 10 & 123 & 8.5 \\
\hline Por 6 años & 42 & 3 & 6 & 6 & 11 & 14 & 11 & 4 & 15 & 112 & 7.8 \\
\hline Sin sentencia (procesados) & 88 & 11 & 14 & 22 & 27 & 27 & 10 & 12 & 14 & 225 & 15.6 \\
\hline TOTAL & 605 & 61 & 79 & 111 & 108 & 144 & 103 & 106 & 144 & 1443 & 100 \\
\hline
\end{tabular}

"Comentario: Teniendo en consideración que del total de la población atendida al mes de marzo ascendente a 1,869, se ha identificado que un $77 \%$ de adolescentes cumplen la medida de internamiento entre 13 meses a 6 años, y un $23 \%$ de adolescentes tienen medida de internamiento entre 1 a 12 meses."

Fuente: Poder Judicial. (2015). Duración de la medida impuesta (medio cerrado). Elaborado por la Administración de los Centros Juveniles de Medio Cerrado.

Este cuadro muestra que el porcentaje mayor al $77 \%$ mantiene a los menores más de un año bajo encierro, tiempo suficiente para que el "contagio criminal” se expanda. Resulta fácil ser

\footnotetext{
15 Palabra que significa "Red de trabajo", más utilizada en el ambiente comercial y laboral.
} 
influenciado por alguien con el que se convive por unos días, meses y años; más aún cuando la mayoría de los jóvenes recluidos mantienen "medidas socio educativas" muy largas.

Está demostrado que la violencia guarda una estrecha relación con el estrés y con el incremento de la actividad emocional de la impulsividad. De este modo, cuanto mayor, es la actividad, y más estrés genera ésta, mayor será la capacidad de agresión. También el incremento de la actividad sexual estaría relacionado con el aumento de los comportamientos agresivos, ya que en la medida en que no se satisfaga el apetito sexual se incrementará la conducta violenta.

(Brage Cedán, 2013, p.25).

"Una vez que los delincuentes recluidos experimentan la estigmatización y se ven aislados por la sociedad, el aislamiento y la estigmatización funcionan como elementos que impiden que reconozcan sus acciones. El encarcelamiento hace burla del crecimiento humano, del cambio personal y de la responsabilidad moral" (Tkachuk, s.f., p.246). Por tanto, mantener un pensamiento de escarmiento y castigo resulta contraproducente. Los resultados que se obtienen cuando se encierra en un mismo edificio a jóvenes que cometieron distintos ilícitos, crea en el más tímido y torpe infractor, sentimientos de venganza y rebeldía contra el sistema y la sociedad. Asimismo, el rechazo total a los conocimientos que se intentan impartir en la correccional, el desafío y la apatía son respuestas esperadas en los infractores en un ambiente de encierro.

No debemos olvidarnos que el Derecho penal no puede actuar impulsado por ninguna reacción social no razonada, o alentado por el calor de casos que irritan a la realidad social. Al respecto, bien lo señala el profesor Miguel Polaino Navarrete, no puede legislarse tras el golpe emocional de un sangriento suceso de la realidad social, especialmente en materia penal, ya que su consecuencia será siempre un resultado insatisfactorio, insuficiente, ineficaz o directamente contraproducente. Por el contrario, el legislador penal tiene que ser extremadamente cauto, ponderado y previsor en su tarea incriminadora de nuevas formas delictivas; ésa consideramos, es una de sus más significativas misiones.

(Jakobs y Polaino Navarrete, 2006, p.79).

En conclusión, el ideal para afrontar el síntoma criminal es brindar una condena proporcional, que observe el daño y el "beneficio" de la conducta típica. Debemos ser congruentes entre el tiempo que definimos como castigo y la posibilidad de una reinserción efectiva. El tiempo de encierro sirve a los delincuentes en general y a los menores infractores para aprender y mejorar sus tácticas criminales. Adoptar medidas como la del Medio Abierto genera opciones y mitiga de manera importante los efectos del hacinamiento y de la especialización criminal (especialización en tanto la experiencia y conocimiento criminal diverso del grupo de jóvenes infractores). 


\section{2.- Tendencia general de la cultura de castigos}

"En Moscovia, donde la pena es la misma para asesinos y ladrones, los ladrones asesinan siempre. Como ellos dicen, los muertos no cuentan nada" (Perry, 1999, p.63). La respuesta inmediata que la sociedad tiene para alguien que ha cometido un delito es la pena privativa de la libertad, es un castigo que se debe de cumplir; el precio por infringir las normas y sacar un beneficio ilícito y dañoso para la sociedad. Cuando esta condena se ve alterada por un escape, la natural respuesta es la de volver a castigar, pero ahora con mayor severidad.

El factor situacional determina la conducta; ella empuja al Derecho a convertirse en herramienta de nuestra sociedad apoyada por la fuerza del Estado.

Las vulneraciones de los riesgos prohibidos deben ser objeto de respuestas estatales y acciones canalizadas para brindar resultados específicos. Deben ser soluciones apropiadas y consecuentes con la realidad nacional. "En un pasaje ya acotado por Wilhelm von Humboldt, señala dos cosas como condiciones necesarias para el desenvolvimiento humano, en cuanto necesarias para hacer a las gentes desemejantes una de otras, a saber: libertad y variedad de situaciones" (Stuart Mill, 2013. p.175).

No obstante, la cultura de castigo alentada por los medios masivos de comunicación crea un fenómeno que se llamará Contexto Ideal del Castigo:

\section{Un Contexto Ideal del Castigo}

1.- Manifestación del Problema: La normalidad se quiebra, decae el estado de bienestar y son amenazados y vulnerados nuestros Derechos Fundamentales.

2.- La Petición de la Nación: Tiene como finalidad contrarrestar el problema, en ese sentido, se solicita la elaboración de nuevas leyes, cambios en la administración de Justicia y Carcelaria, nuevas estrategias para mitigar las consecuencias de este problema.

3.- La inacción del Estado: El Estado es consciente sobre los problemas que merman la calidad de nuestros Derechos Fundamentales, pero sus políticas no son eficaces.

4.- Crecimiento del Problema: Si la medida adoptada por el Estado no funciona, el problema se fortalece, expande y amenaza con volverse crónico. Los daños causados no son ocasionales, más bien cotidianos y de mayor gravedad. 
5.- Respuesta eficaz y acción de la Nación: Cuando el Estado es ineficaz, la Nación reacciona en defensa propia y el ius puniendi deja de ser, en la realidad, sólo una prerrogativa estatal, para convertirse en una social. La Nación castiga, oprime y se protege. 6.- La intervención ideal del Estado: Las garantías impuestas por el sistema Judicial son respetadas, el Estado implementa un mejor sistema, con respuestas eficientes para el problema que se generó.

En esa estructura de ideas, nos encontramos en la última etapa; el problema se desbordó, causó mucho daño y aún nos afecta, la sociedad está luchando y acepta la eliminación de algunas garantías constitucionales. El Estado debe introducir las garantías y derechos constitucionales a la lucha contra la inseguridad y el crimen. "En proporción al desenvolvimiento de su individualidad, cada persona adquiere un mayor valor para sí mismo y es capaz, por consiguiente, de adquirir un mayor valor para los demás. Se da una mayor plenitud de vida en su propia existencia y cuando hay más vida en las unidades hay también más en la masa que se compone de ellas" (Stuart Mill, 2013. p.160).

El valor de un Estado, a la larga, es el valor de los individuos que lo componen; y un Estado que pospone los intereses de la expansión y elevación mental de sus individuos a un poco más de perfección administrativa o a la apariencia de ella da la práctica en los detalles de los asuntos; un Estado que empequeñece a sus hombres, a fin de que puedan ser más dóciles instrumentos en sus manos, aun cuando sea para fines beneficiosos, hallará que con hombres pequeños ninguna cosa grande puede ser realizada; y que la perfección del mecanismo, a la cual todo lo ha sacrificado, terminará por no servirle para nada por falta del poder vital que, en aras de un más fácil funcionamiento de la máquina, ha preferido proscribir.

(Stuart Mill, 2013. p.175).

Por tanto y según la reflexión de John Stuart Mill, el valor singular y propio de cada persona es otorgado por el valor que el Estado imprime en la comunidad que lo conforma; el valor no es ajeno ni aleatorio, es proporcional. Es por ello, una consecuencia lógica que el primer artículo de nuestra Constitución demuestre una preocupación por la defensa de la persona humana y de su dignidad; ambas categorías brindan valor y relevancia a las personas.

\section{3.- Sobre los fallos judiciales}

"El juez se convierte en enemigo del reo, de un hombre encadenado, entregado como presa a la sordidez, a los tormentos y al más terrible porvenir; no busca la verdad del hecho, sino que busca 
en el prisionero el delito; y lo asedia y cree perder si no lo logra; y perjudicar a aquella infalibilidad que el hombre se atribuye en todas sus cosas” (Beccaria, 2012, p.87). ¿No será que todo este sistema se apoya en la idea del castigo y no se presta ningún enfoque al origen del problema? La sociedad reclama el castigo para dar por resuelto el problema; se ha perdido la idea de la prevención general positiva en favor de la sociedad y no se trabaja en ese sentido. Desechar la idea de prevención criminar tiene consecuencias futuras y muy nocivas para la sociedad.

(...), parecerá extraño, a quién no reflexione que casi nunca ha sido la razón la legisladora de las naciones, que los delitos más atroces o más oscuros y quiméricos, es decir, aquellos cuya improbabilidad es mayor, se prueben por las conjeturas y las pruebas más débiles y equívocas; como si las leyes y el juez tuvieran interés, no en descubrir la verdad, sino en encontrar el delito; como si no hubiera tanto mayor peligro de condenar a un inocente cuanto la probabilidad de la inocencia supera a la del delito.

(Beccaria, 2012, p.36).

En este contexto, no podemos pensar que enviar a un menor a un centro como el de Maranga sea una decisión adecuada para lograr un buen comportamiento o aprendizaje, mucho menos resulta óptimo como una forma ideal de escarmiento (Merino, 2007). La alta violencia que se genera en estos lugares se establece en todos los niveles. En ese sentido, el Juez Federal de la Nación Argentina, Sergio Gabriel Torres expone que: “Actualmente, el legislador sanciona penalmente toda conducta valorada como disvaliosa; no importa si es leve o secundaria, o si refiere a conductas socialmente admitidas. Con ello, aumenta indiscriminadamente el campo de acción penal en lugar de brindar soluciones plausibles que superen los riesgos por ellos debatidos (distribución de riquezas, mejora del servicio de justicia, etc.). Hoy todo forma parte de la materia criminal, hoy por hoy, todo es merecedor de reproche penal" (Gabriel Torres, 2012, p.141).

Los cuadros (ANEXO 1) elaborados por el autor de la tesis, producto de la evaluación de las sentencias en que aplicaron la medida socioeducativa de internamiento (sentencias facilitadas por la Administración Centro Juvenil de Diagnóstico y Rehabilitación de Arequipa), demuestran el perfil del Operador de Justicia. Es posible deducir la falta en la aplicación del Principio de ultima ratio de la ley penal y la nula utilización de la Remisión como medida necesaria para el bienestar de la comunidad y del adolescente infractor. Como dice expresivamente Ferrajoli, "si la historia de las penas es una historia de horrores, la historia de los juicios es una historia de errores" (Pietro Sanchís, 2007, p.66). 
En época de ignorancia, no se vacila aunque las resoluciones produzcan grandes males; en tiempo de luces, aun los mayores bienes se resuelven temblado. Se ven los abusos antiguos, se comprende la manera de corregirlos; pero también se ven o se presienten los abusos de la corrección. Se deja lo malo si se teme lo peor; se deja lo bueno si no se está seguro de mejorarlo. No se miran las partes si no es para juzgar del todo; se examinan todas las causas para ver todos los resultados.

(Montesquieu, 1999, p.xvi).

Aparentemente el Operador de justicia intenta sumar las penas, que son muy duras si la infracción se cometió de noche, si la víctima fue otro menor de edad (16), si amenazó, con qué lo hizo, si se utilizó un arma y si hay más de un sujeto activo. Toda vez que estos supuestos representan circunstancias de agravación. “(...), el 70\% manifestó que en más de una oportunidad solicitaron o aplicaron internación por falta de soporte familiar" (Consejo Nacional de Política Criminal, 2014, p.76).

Asimismo, es recurrente para los Operadores de Justicia el empleo del precepto penal y de la consecuente interpretación literal de la ley penal, ello empuja a que la administración judicial utilice estos preceptos penales como una especie de checklist $^{16}$ y la subsunción deviene en una operación mecánica y objetiva; sin humanidad y tampoco se consideran las condiciones ineficientes del sistema de castigo. Es por ello que resulta necesario emplear el método de interpretación sistemática y teleológica, ya que incluye la finalidad que recubre al derecho penal: educación, disuasión y resocialización.

CAPÍTULO II De las Leyes divinas y de las leyes humanas.

Las leyes divinas no deben estatuir sobre lo que corresponde a las humanas, como éstas no deben invadir lo que corresponde a aquéllas.

Son dos especies de leyes que difieren por su origen, por su objeto y por su naturaleza. Todo el mundo conviene en que las leyes humanas son de otra naturaleza que las religiosas, y éste es un gran principio; pero este mismo principio depende de otros que es necesario buscar.

1. La naturaleza de las leyes humanas está sometida a todos los accidentes y a variar a medida que cambia la voluntad de los hombres; las leyes religiosas estatuyen sobre lo mejor. Lo bueno puede tener varios objetos, pero lo mejor es único. Es posible modificar las leyes, porque basta que sean buenas; pero las instituciones religiosas no pueden cambiarse, porque, siendo mejores, cualquier mudanza las desmejoraría.

2. Estados hay donde las leyes no son nada, o no son más que la voluntad caprichosa y pasajera del soberano. En esos Estados, si las leyes religiosas fueran de igual naturaleza que las leyes humanas, tampoco serían nada; y como es necesario que en la sociedad haya algo permanente, ese algo es la religión, lo más fijo que existe en la sociedad.

La fuerza principal de la religión es que se cree en ella; la fuerza de las leyes humanas está en que se las teme. La antigüedad es conveniente para la religión, pues creemos en las cosas tanto más cuanto más lejano esté su origen, por no tener ideas accesorias de la misma época remota que las

\footnotetext{
${ }^{16}$ Lista de comprobación.
} 
contradigan. Las leyes humanas, por el contrario, sacan fuerza de la novedad, que demuestra la atención actual del legislador para hacerlas respetar.

(Montesquieu, 1999, pp.328-329).

En adición, esta crítica se puede extender a la Policía Nacional y al Ministerio Público, al respecto:

Los agentes policiales no poseen un enfoque restaurativo que permita un trato adecuado a los adolescentes detenidos y a las víctimas. Asimismo, los fiscales y los jueces no priorizan la aplicación de las remisiones. Mientras los fiscales priorizan la judicialización del conflicto, los jueces priorizan las privaciones de libertad preventivas y las medidas de medio cerrado, antes que procesar en libertad y aplicar remisiones, respectivamente. (Consejo Nacional de Política Criminal, 2014, p.77).

\section{4.- La víctima y la sociedad}

En un sistema retributivo, la persona que vulnera el ordenamiento jurídico retribuye su conducta con un castigo, ello implica alejarlo de la sociedad para que expíe su pena, entienda el desvalor de su conducta y, una vez rehabilitado, tenga la opción de retornar a la sociedad. Es decir, el infractor cumple una medida de internamiento porque resulta útil y necesario para la sociedad. Sin embargo, bajo este sistema la víctima queda en un estado de vulnerabilidad, ya que no conoce las razones de la conducta delictiva que afectó sus derechos, del mismo modo el sistema retributivo no asegura que la conducta dañina se vuelva a repetir, y no recupera (cuando la naturaleza del bien jurídico lo permita) el objeto material afectado.

Para las teorías absolutas, la pena retribuye o expía la culpabilidad del autor. En la literatura científica se suele calificar a las teorías absolutas como teorías retributivas, por entenderse que no buscan prevenir la comisión de delitos. La pena se desvincularía de su efecto social y se trataría de una simple retribución por un mal (delito) causado. Así entendidas (lat. absolutus = desvinculado), las teorías absolutas no serían teorías sobre los fines de la pena sino teorías penales. Ello es de recibo siempre y cuando el término «fin» se entienda como utilidad social derivada de la imposición de la pena, ya que incluso la pena concebida como retribución de la culpabilidad cumple la función de restablecer el orden jurídico y de realizar justicia.

(Meini, 2013, p.145).

Por ello, es necesario utilizar las medidas que existen en el ordenamiento jurídico moderno y vigente que se inclinan por un sistema de Justicia Restaurativa; bajo el cual la víctima conoce las razones de la conducta delictiva, recupera (o es reparado) el objeto material dañado y en alguna medida crea el interés de la propia víctima en el problema criminal: asimila que el factor social es determinante para la conducta criminal, en ese sentido, las medidas radicales y deterministas 
dejarán de utilizarse; la excusa denominada Defensa Social se desplaza por la conciencia/responsabilidad compartida. Ello evita además que el infractor sufra un etiquetamiento porque se evita el contacto con el aparato formal de control social; por el contrario, la Justicia Restaurativa soluciona el problema dentro de las instituciones de control informal y en un tiempo oportuno. Este aspecto será desarrollado en el Capítulo IV de la presente investigación.

En adición, existe una cuota de desinterés social inmerso en la trasgresión de los riesgos prohibidos; las personas quieren eliminar el crimen, sin importar sus causas ni consecuencias. La criminalidad es producto de la comunidad. En este contexto, es posible evitar la comisión de nuevos delitos/infracciones, principalmente en la interacción de dos enfoques, la prevención de conductas -atendiendo las causas y la reducción de factores de riesgo- y la justicia restaurativa que elimina (entre otras variables) el efecto puerta giratoria ${ }^{17}$ que ocasionan mayormente los centros de internamiento de medio cerrado (McNeill, F., Farrall, S. And Maruna, S., 2012).

Resulta además que la medida de internamiento en medio cerrado deviene, en muchos casos, en un sistema de castigo contraproducente; donde todavía se utiliza el desfasado daño corporal como instrumento de educación y disuasión. Esta implementación de un sistema violento mantiene una relación directa con la creación de personas sin conmiseración, ya que los menores infractores son forzados a una convivencia que no discrimina el contacto con nuevas conductas delictivas. La reproducción constante del fenómeno eleva cada vez la criminalidad y la victimización.

En consecuencia, extender el supuesto de Remisión que se propone en esta Tesis, implicará la reducción en el contagio del síntoma criminal. Toda vez que se evita el Contacto Diferencial, por intensidad y durabilidad en el medio cerrado (donde se han añadido y habitan distintos perfiles criminales con múltiples edades). A menor número de criminales menor número de víctimas, en consecuencia, menores vulneraciones de riesgos prohibidos.

\footnotetext{
${ }^{17}$ Fenómeno por el cual, las personas que entran al medio cerrado se convierten en "ciudadanos de segunda clase" etiquetados y marginales. En Aquel contexto, cuando su medida de internamiento termina, el grupo mayoritario vuelve a reincidir. De esa manera el medio cerrado se convierte en una constante, llena de reingresos; en aquel contexto es muy difícil reintegrarse a la sociedad.
} 


\section{CAPÍTULO V: EVASIÓN Y LIBERTAD}

\section{1.- Sobre la libertad y la fuga}

\section{a) El contexto de la libertad}

Somos pasibles de transformación, el ser humano es forjado por sentidos que desarrollan un recuerdo, ello genera una costumbre, y el conjunto de costumbres formarán experiencias, que racionalizadas constituirán aprendizaje (Aristóteles, 2005). Ahora bien, cuando una persona enfrenta un entorno extremo, ésta desarrolla respuestas apropiadas de defensa, en intensidad y durabilidad. La adrenalina es el elemento esencial y necesario para enfrentar un entorno nuevo y desconocido, además brinda la fuerza necesaria para repeler un ataque y/o consumar una fuga. No obstante, las intensidades de ambas reacciones disminuyen de manera progresiva en el tiempo, se difuminan, ya que la mente se adaptada al contexto conocido y se generan nuevas reacciones (derivadas de la experiencia); dirigidas a obtener conocimiento. En aquel momento, el cuerpo ya no identifica peligro, sino más bien lo interpreta como su medio habitual, lo confunde con el medio en el que se encuentra y se establece la costumbre; el cuerpo humano no genera más adrenalina, porque no encuentra un contexto desconocido.

Ello también genera un riesgo para el programa resocializador, ya que la persona acostumbrada a un medio alejado de las prácticas normales de la vida en sociedad, obtendrá una mecánica diferente, asocial, y con ella las opciones de resocialización decrecen.

Ahora bien, la adaptación frente a un medio nocivo es posible; por ello, cuando el "ataque" resulta muy difícil o imposible de repeler, el sistema de defensa entiende que el medio natural y estable es el encierro, la violencia, las órdenes, los límites de imaginación, la segregación, la discriminación, etc. De manera adicional y para el caso concreto, los menores encerrados tienden a formar grupos, como mecanismo eficaz para repeler abusos y situaciones extremas. Es decir, necesitan asociarse para mitigar ataques y obtener beneficios tales como: llamadas telefónicas, comidas diferentes, cigarrillos, alcohol, drogas, seguridad.

Asimismo, toda persona circunscrita a un esquema que restringe la libertad necesita acoplarse a un grupo. La aceptación de sus integrantes se encuentra supeditada a la celebración de un ritual, situación en la que convergen distintos desafíos y promesas. El "nuevo" tendrá que 
probar su utilidad dentro del grupo, demostrar la ganancia que los demás obtendrán de él; buen manejo de armas, corpulencia, cicatrices, la naturaleza de la infracción cometida, etc. La habilidad del aspirante será evaluada y de ello dependerá su supervivencia, deberá obtener nuevos conocimientos, compartir beneficios con los demás, defender al grupo; en consecuencia, el nuevo integrante deberá mostrar fidelidad y sacrificio para el grupo, el propósito es ser parte de una "familia".

Al recluso, al que se le priva prácticamente durante el tiempo de cumplimiento de la pena de los contactos íntimos y sociales, se le coloca en un ambiente que le mantiene separado de los problemas en los que ha fracasado fuera del establecimiento penitenciario (creándoles además nuevos problemas); olvida las técnicas sociales de relación y afirmación ante los demás (y aprende otras distintas). Es lo que el penitenciarista americano Clemmer (The prison community) llamó prisonización y el sociólogo también americano Goffman (Internados) enculturación, refiriéndose a otras formas de vida en las que el sujeto está privado de su libertad, como los manicomios y otros centros totales de convivencia obligatoria y similar limitación de libertad. Tanto la prisonización, como la enculturación constituyen un proceso de adaptación a las formas de vida, usos y costumbres vigentes en el centro de internamiento, donde el recluso convive obligatoriamente con otros internos aprendiendo una forma de vida que es precisamente la contraria a una vida en libertad sin delitos.

(Hassemer, Winfried, Muñoz Conde, 2012, p.174).

En ese sentido y para el caso especial de los menores internos, se cumple el mismo patrón de conducta: formación de grupos, comportamiento homogéneo, obediencia y respeto a un líder. El líder, posee algunas características especiales como tiempo prolongado dentro de la correccional, reincidencia, severidad de la infracción cometida, tatuajes en modo críptico y más cicatrices en la piel. Todos los que integran esta hermandad tienen un modelo impuesto, es definido por el líder al que acompañan, cubren y obedecen por mantener el buen clima y beneficio grupal.

En ese sentido, estos menores son arrastrados por los modelos más contaminados, su opción es limitada y dirigida a un medio asocial. Seguirán a la persona que le brinde seguridad, esa es una forma de repeler el ataque; recordemos, el ser humano en un ambiente hostil, repele el ataque o huye, es la respuesta natural. En este caso no es diferente, la persona mitiga el ataque y reacciona para defenderse; con ese propósito se incluye en un grupo, ello le permite defenderse, no ser "presa fácil". No obstante, observamos que la segunda reacción esperada, producto del medio nocivo en encierro, es el escape. La reacción no termina, se desarrolla de manera constante, en señal de instinto. Desde el primer momento en encierro se estudian las estructuras, la finalidad es conocer muy bien las instalaciones, trazar un plan y fugar. Cualquier persona, en un contexto de encierro 
tiene, en todo momento, la idea de escaparse; en adición y al permanecer en un grupo donde todos comparten las mismas sensaciones, este anhelo se agudiza hasta volverse crónico.

En suma, los "grupos" descritos mantienen integrantes con infracciones de naturaleza variada, en participación e intensidad. Aquello permite concluir que los menores que cumplen una medida socio educativa como consecuencia de hurtar bienes o dinero, puedan ser integrantes de un grupo donde predominan delitos/infracciones que afectaron bienes jurídicos fundamentales como la vida y la libertad sexual. Recordemos que la tercera infracción más castigada por los jueces es el hurto. En esta infracción no confluyen la fuerza, violencia, armas ni amenaza; el agraviado no se percató en el momento en el que su bien dejó de pertenecerle y en la mayoría de los casos la cuantía de estos bienes es ínfima y una medida de encierro resulta desproporcional. La libertad, como bien jurídico protegido, no puede ser equiparada al patrimonio.

Por tanto, conscientes del contexto psicológico y físico de las personas que afrontan un encierro, se debe brindar políticas adecuadas para contrarrestar las desproporciones y la nocividad del sistema. El Derecho penal defiende de manera objetiva los bienes jurídicos fundamentales; sin embargo, atender el aspecto subjetivo resulta esencial para determinar la responsabilidad penal y castigo a imponerse. En ese sentido, es necesario también comprender los aspectos subjetivos de las personas en un medio de encierro, ello conllevará a la creación e implementación de programas adecuados, centrados en la resocialización y rehabilitación (Roxin, 2014).

\section{b) Libertad: sus pensadores emblemáticos}

"He aquí, pues, un suplicio y un empleo del tiempo. No sancionan los mismos delitos, no castigan el mismo género de delincuentes. Pero definen bien, cada uno, un estilo penal determinado" (Foucault, 1999, p.314). Los castigos han evolucionado, la historia nos demuestra que los suplicios convergen y se tornan cada vez menos físicos y más sutiles. El castigo ha cesado poco a poco de ser un arte escénica donde era posible comparar al Juez con el asesino, al verdugo como el animal y al supliciado como un objeto: motivo de compasión, admiración y sometimiento.

A finales del año 1787 aún se castigaba con muertes de espectáculo (Foucault, 1999), el nexo directo de estas ejecuciones recordaba la cara más oculta y nada agraciada del Proceso Penal: el castigo violento.

Foucault añade que el suplicio, entendido como la pena corporal, dolorosa, más o menos atroz, debe de producir cierta cantidad de sufrimiento que no se pueda apreciar, comparar o 
jerarquizar; y es ahí, en los excesos de los suplicios, donde se manifiesta toda una economía del poder (Foucault, 1999).

En el año 1792 se emplea un mecanismo donde torna impersonal el ejercicio de la ejecución y el enfrentamiento físico: la guillotina. Y poco a poco se van cambiando las grandes plazas, por calles menos transitadas, luego a patíbulos y en algunos casos se sustituyen cuellos por la muñeca de la mano elegida (año 1832). En Francia y en la mayoría del continente europeo desaparece el castigo físico a comienzos del siglo XIX: el gran espectáculo. La necesidad de castigo sin suplicio; humanidad como medida; "Medida y Humanidad" (Foucault, 1999).

Foucault explica que el castigo es un espectáculo que es necesario prohibir. "Pero un castigo como los trabajos forzados o incluso como la prisión -mera privación de la libertad- no ha funcionado jamás sin cierto suplemento punitivo que concierne realmente al cuerpo mismo: racionamiento de alimento, privación sexual, golpes, celdas, (...)" (1999, p.23). El mismo autor entiende que esta época es definida como la evolución de la locura en la práctica penal, pues el delito mismo desaparece, los objetivos varían, en este momento es una herramienta: su funcionalidad es encerrar, alejar el peligro y cuidar al interno; la finalidad antigua del castigo queda desplazada (1999, p.314).

Este sistema que trasgrede derechos fundamentales, es el que tenemos ahora en nuestro País. En un contexto de percepción de alta inseguridad y de escasa resocialización, utilizamos al castigo como medida desesperada, sin pensar en las consecuencias de su implementación, nos hemos centrado en un mecanismo que arroja más contrariedades que aciertos.

Pero existen sociedades que han pasado por estos mismos escenarios, países que ya no están en la categoría de "en vías de desarrollo", sino que son para la humanidad "primeros en el mundo". Hace 150-200 años que Europa ha establecido nuevos sistemas de penalidad: Juzgan el "alma" de los delincuentes (Foucault, 1999). Se desplazó el "quién" por el "cómo"; en el sentido de mecanismo para prever la evolución del sujeto, conocer y establecer sistemas para encontrar la manera de corregirlo con más seguridad (en el sentido de confiabilidad).

En este sentido, surgen tres preguntas desde el año 1958 (en el sistema europeo): ¿Presenta el inculpado un estado de peligro? ¿Es accesible a la sanción penal? ¿Es curable o re-adaptable? Éstas son las bases que determinan el encierro de una persona, como más adelante desarrollaremos en esta tesis, estas tres preguntas se cambian por opiniones de un juzgador, la presión/temor social y la prensa mediática. 
El juez o jueza (aparentemente de manera generalizada) siente que es su deber encerrar a las personas que trasgreden las normas, ésa se convierte en su solución más idónea, no coloca en consideración las consecuencias del encierro; las vejaciones que se llevarán en el medio cerrado y sobre todo la reacción al efecto de estar inmerso entre delincuentes más experimentados y con infracciones variadas. Él o ella, considera que cumple con la ley.

En adición, la prensa con sus juicios mediáticos puede presionar para encerrar a quien decida, no importa si es un menor de edad, lo encerrarán con los mayores, las contingencias se las dejan a la adaptabilidad del sistema y las consecuencias al futuro que ellos no esperan transmitir. Además, es necesario resaltar que la prensa busca vender ${ }^{18}$, está guiada por hacer más violenta y nociva a la noticia criminal, estará enfocada en los homicidios y robos graves (Barkan, 2012).

Los medios de comunicación mantienen un rol principal en el empleo y éxito de las políticas criminales. "La prensa, entendida como instrumento de cualquier género empleado para la difusión del discurso humano mediante signos visibles, tiene dos usos: moral y político. El uso moral consiste en poner freno a los desórdenes de la conducta en la vida privada; el político, en poner el mismo freno a los desórdenes de la conducta pública” (Bentham, 1990, p.157). Dicho ello, colocar soluciones en lugar de crear una necesidad de inseguridad constante, resulta necesario. Las noticias con altas cuotas de violencia amplían los márgenes de intolerancia y ello empuja a actuar con igual o mayor violencia; un círculo sin virtud que aumenta el rango de daños y desaciertos.

Kant explica el significado de la libertad "Si un hombre está sujeto a otro hombre, no es libre; si se somete al volcán de sus pasiones, tampoco lo es; solo si está sujeto a una norma justa que él mismo acepta logra ser libre. Cuando uno toma una decisión fundamental en su vida, debe preguntarse si la norma que lo guía podría convertirse en ley universal” (Grondona, 1994, pp.72-

\footnotetext{
18 "Often the media's crime coverage continues to be heavy even though the crime rate may be declining. For example, murder stories on the TV networks' evening newscasts surged, thanks in part to the O.J. Simpson murder case, by 721 percent from 1993 through 1996 (Kurtz 1997). This heavy crime coverage heightened fears that crime was soaring even though the U.S. homicide rate had actually dropped by 20 percent during that time, prompting one TV news reporter to comment, "The myth of rapidly rising crime is so widespread that almost every report (er) believes is true. I'm as guilty as anyone" (William 1994)." Traducción: A menudo, la cobertura de delitos de los medios sigue siendo muy dura, aunque la tasa de delincuencia puede estar disminuyendo. Por ejemplo, las historias de asesinatos en los noticiarios de las redes de televisión crecieron, gracias en parte al O.J. Simpson, por 721 por ciento desde 1993 hasta 1996 (Kurtz 1997). Esta fuerte cobertura de la delincuencia aumentó los temores de que la delincuencia estuviera en alza, a pesar de que la tasa de homicidios en Estados Unidos había bajado un 20 por ciento durante ese tiempo, lo que llevó a un reportero a comentar: "El mito del rápido aumento de la delincuencia está tan extendido que casi todos los informes creen que es cierto. Soy tan culpable como cualquiera" (William 1994)."
} 
73). No podemos disponer de la libertad de otras personas, instrumentalizar a jóvenes infractores por conceptos volátiles como la peligrosidad.

Como las líneas anteriores desarrollan, dentro de un ambiente de encierro la formación de grupos es natural al contex to y en aquel ambiente (ayudado por una realidad de hacinamiento) las personas más fuertes dispondrán de los más débiles, comerán cuando el líder lo indique, la ración que él disponga y ejecutan las tareas que deberán cumplir para mantenerse dentro del grupo. Las personas en aquel contexto recrean una vez más la teoría del estado natural. De las observaciones realizadas, se concluyen que encajan con mucha facilidad en los modelos brindados por Hobbes, Montesquieu y Rousseau. Hobbes diría que los menores infractores son impulsados por sus pasiones -y dentro del medio cerrado-, buscarán eliminar, atacar y reinar dentro de un clima anárquico. Montesquieu que desarrolla su planteamiento sobre los seres más débiles, explicaría que los infractores primarios ingresan al medio cerrado con poca experiencia criminal y escasa agresividad, en consecuencia, ellos buscarán un grupo para sentirse protegidos, ser fuertes por necesidad. Rousseau, afirmaría que aquellos criminales primarios, sin ninguna experiencia y nada agresivos; no poseen algún conocimiento criminal específico y la búsqueda del grupo estará alentada por el beneficio, la mezcla de virtudes que harán más llevadera la vida sin libertad. Es en esencia posible recrear el estado natural de las personas en la realidad que ofrece el internamiento de medio cerrado, por ello resulta capital establecer un "contrato social" que no permita el contagio del síntoma criminal, cuya columna vertebral esté amparada en el control de las pasiones y de esa manera sea posible obtener la libertad sin algún (nuevo) sometimiento.

Si el hombre no obedece a sus inclinaciones tampoco se obedece a sí mismo, obedece a sus inclinaciones. De una u otra forma, la obediencia es inescapable. El hombre presa de sus inclinaciones no es libre. Hay dos déspotas: el déspota político ajeno a mí y el déspota de las pasiones no contraladas que está en mí. Bajo cualquiera de ellos, se pierde la libertad. No es libre no el esclavo ni el drogadicto, entonces. Kant implica que sólo el hombre que consigue la libertad interior puede reclamar con fuerza la libertad exterior. (Grondona, 1994, p.76).

Es por este motivo que el recurso propuesto aprovecha una ventana en el sistema, una acción de fuga implica que los menores -expuestos a un sistema nocivo- mantengan una libertad interior. En un ambiente de encierro la obediencia al más fuerte se impone, el déspota controla al más débil y recobrar el estatus anterior es una aventura muy difícil de cumplir (Grondona, 1994). 
En adición es apropiado citar que: "Somos libres y estamos condicionados. He aquí entonces la proposición kantiana: “Tenemos que luchar para que se amplíe en nosotros el mundo de la libertad". Es una batalla que sólo tiene que dar el hombre porque es un ser mixto. Si reducimos todo a la razón, excluyendo los sentidos, lo que queda es la forma, vacua de contenido, pero el materialismo cae en el exceso opuesto. Ni ángel ni animal, el hombre es el combate entre el ángel y el animal que lleva adentro" (como se cita en Grondona, 1994, p.78). La búsqueda de la libertad implica una respuesta, caracterizada por la creación de oportunidades. Y si un contexto de fuga no violenta trae como consecuencia una respuesta violenta, entonces surgirá un reclamo (por el ejercicio de un instinto arrebatado). Kant habla de una lucha, esta tesis supone un ejemplo de aquella postura; la acción de fuga es producto de la influencia y lucha que describe aquel autor.

Asimismo, se desprende de las prácticas habituales del medio cerrado -trato e indiferencia sobre la persona que cometieron alguna infracción, sin importar la gravedad o daño-, una pérdida de valor intrínseca para el infractor de la ley penal. Personas que experimentan el estigma del medio cerrado se autodefinen como ciudadanos de segunda clase (McNeill, Farrall, Maruna, 2012). Las pruebas de este fundamento abundan, verbigracia, la difícil -casi imposible- reinserción laboral. En este sentido, es importante "mantener" el valor de las personas que ingresan a un centro penitenciario o de diagnóstico/rehabilitación. ¿Cómo lograrlo?

Cuando Nozick comienza sus Explicaciones..., dice que está interesado en demostrar algo concreto: que filosóficamente es posible sostener que los seres humanos somos valiosos. Esto tiene un alcance político, porque sólo si somos valiosos, vale la pena darnos la libertad. Si no somos valiosos, ¿para qué? La explicación filosófica está dirigida a fundamentar la concepción política del liberalismo. Como cada hombre es un ser valioso, que puede tener un proyecto de vida, cuya existencia "hace una diferencia" (en el Universo), vale la pena darle la libertad.

(Grondona, 1994, p.155).

Es un deber ético el mantener el valor de las personas que vulneraron la ley penal y es necesario brindar la oportunidad de enmienda, corrigiendo la desproporción de las penas, los errores judiciales, la baja calidad en las defensas, la presión popular, etc. Si revestimos de valor a este grupo humano lograremos construir un nuevo camino de reinserción real y con una sociedad de más elevado nivel.

De igual modo, para cosechar productos derivados de los principios, se deberá sembrar en las personas precisamente aquellos principios y ponerlos en práctica. Es decir, si buscamos solidaridad, debemos ser solidarios con ellos, orden, calidez, respeto, trato amable y constante. 
Nozick distingue varios tipos de valores. Algo que tiene un valor "instrumental" cuando sirve para otra cosa que es valiosa. En cambio, hay valor "intrínseco" cuando algo tiene valor por sí mismo. Por supuesto, el hombre ha de ser valioso intrínsecamente y no con un sentido instrumental si es que vamos a darle libertad. También algo puede ser valioso en el sentido de que "contribuye" a la formación de un valor (valor contributivo). Por ejemplo, el brazo es valioso en cuanto forma parte de un cuerpo. En cambio algo tiene valor "originativo", si aporta un nuevo valor. Nozick dirá que cada ser humano aporta una nueva constelación de valores absolutamente única al Universo. Por lo tanto, tiene que demostrar que somos valiosos en forma intrínseca -no solo instrumental- y originativa -no solo contributiva-. No es que simplemente nos agregamos a cosas valiosas; "somos" valiosos porque cada uno de nosotros aporta una nueva combinación de valores que de otro modo no existiría. De ahí la frase: "Que tú existas, hace una diferencia".

(Grondona, 1994, p.156).

Un fragmento de la posición de Grondona que supo explicar el efecto placebo, es pertinente llevar su interpretación al campo práctico y penitenciario:

Nozick explica esta opción existencial acudiendo al tema de los "placebos" o remedios imaginarios. Vamos al médico y éste nos da un placebo sin decirnos que lo es. Lo tomamos creyendo que es un remedio, y como nuestro mal era psicosomático, nos hace bien; por lo tanto, no fue un placebo, sino un remedio. Si alguien vive la vida creyendo que la vida tiene valor, resulta que tiene valor, por lo tanto, tenía valor. La actitud del que toma el placebo determina si el placebo va a ser tal o va a ser un medio. Nozick expone aquí la esencia del espíritu norte americano; es espíritu "positivo". En la medida en que una sociedad resuelve que hay una oportunidad, la hay.

(Grondona, 1994, p.160).

Por tanto, si la comunidad considera que los jóvenes que cometen infracciones leves también representan una oportunidad para incrementar el ratio económico del país, el trato hacia ellos cambiará. Nos convenceremos que ellos también podrían ser buenos trabajadores, que pueden aportar más que destruir; si cambiamos el enfoque, también brindaremos valor a este grupo de personas. Ellos creerán en sus habilidades, buscarán la salida del mundo infractor y criminal, solicitarán ayuda y se sentirán también responsables por la comunidad, ello incluye su progreso y desarrollo propio. La atribución de valor, bajo la óptica de Nozick, es un fundamento que también combate la criminalidad.

Asimismo, Nozick elabora una receta ya que "Nos muestra cuán atractiva es la vida en libertad. Pero también, cuán cooperativa, cuán respetuosa del otro, cuán abierta al otro es la vida en libertad. Es que la solidaridad se realiza mucho mejor a partir del perfeccionamiento individual que a partir de la coacción estatal" (Grondona, 1994, p.160). Este método refuerza lo comentado en los párrafos anteriores, inspira a la solidaridad como medio educativo, lo superpone al método 
acostumbrado del castigo. Nos deja con una interrogante ¿Será más eficiente la solidaridad - o la benevolencia de Adam Smith- que el castigo para el control criminal de la sociedad?

Si yo sé que mi vida vale la pena, que tiene sentido, que hay un proyecto de plenitud, a partir de ahí se hace visceral la petición de las libertades "visibles". Hay que empezar a estudiar más de cerca el lado "invisible" de la libertad. Aquello para lo cual somos libres, o dicho de otra manera, qué va a hacer cada uno con su libertad. Cuando la gente se le encienda el interés por todo lo que puede hacer con su libertad, va a demandar mucho más vigorosamente que haya libertad.

(Grondona, 1994, p.172).

La discriminación mantiene efectos nefastos: pérdida de valor humano, baja autoestima y cuestionamientos constantes. Estas consecuencias restan cuidado con los bienes jurídicos protegidos de terceros. Un delincuente se considera fuera del grupo "sociedad", entiende que su posición es un castigo y el desprecio confirma su postura; con aquellos pensamientos guiados por el odio, repulsión y envidia buscará satisfacer sus necesidades a costa de los demás. Sin embargo, todo esto puede ser distinto si cambiamos y atribuimos valor a este grupo pequeño de personas. No existe espacio para la discriminación y repulsión.

Hayek, reviste de utilidad el concepto de libertad, esta tesis se inclina por esta definición, la comparte y promociona:

"No hemos reclamado la libertad porque deseemos la capacidad para hacer cosas específicas, ni porque consideremos una especial libertad como esencial para nuestra felicidad. El instinto que nos induce a rebelarnos contra cualquier privación física, aunque resulta un aliado de gran utilidad, no es siempre una guía segura para justificar o delimitar la libertad. Lo que importa no es la libertad que yo personalmente desearía ejercitar, sino la libertad que puede necesitar una persona con vistas a hacer cosas beneficiosas para la sociedad. Solamente podemos asegurar esta libertad a las personas desconocidas dándosela a todos.

(Hayek, 2014, p.59).

Finalmente, las ideas de Hayek concatenan lo alentado por Nozick; si se atribuye valor a una persona, ésta representa una oportunidad de convertir a su sociedad en algo mejor, más desarrollado y avanzado. La excesiva cultura de castigo que se desarrolla en el Perú impone sanciones que arrebatan la libertad; el gran número de personas que la pierden no la readquieren plenamente. Por ello, es necesario brindar una puerta de escape, una salida que brinde opciones en los casos razonables- en pos a la reconquista de la libertad. "No conceder más libertad que la que pueda ejercitarse sería equivocar su función por completo. La libertad que se usa por un 
hombre solo dentro de un millón de hombres puede ser más importante para la sociedad y más beneficiosa a la mayoría que cualquier libertad que usemos todos” (Hayek, 2014, p.58).

Es menester señalar que los conceptos desarrollados no solo son aplicados para las esferas interiores o personales de un determinado grupo humano, sino que además resultan útiles para ser aplicados en un contexto de conjunto. Esta idea fue desarrollada también por Hayek en su obra Los Fundamentos de la Libertad:

A través de los esfuerzos mutuamente ajustados de muchos individuos se utiliza más conocimiento del que cualquier persona posee o es posible que sintetice intelectualmente. A través de la unificación del conocimiento disperso se obtienen logros más elevados que los que cualquier inteligencia única pudiera prever y disponer. Debido a que la libertad significa la renuncia al control directo de los esfuerzos individuales, la sociedad libre puede hacer uso de mucho más conocimiento del que la mente del más sabio de los legisladores pudiera abarcar.

(Hayek, 2014, p.57).

Finalmente, la función utilitaria y humanitaria son condensadas con la siguiente idea: "El giro que debe dar el liberalismo ahora es presentarse como un humanismo. En definitiva, es un humanismo, una manera de querer, promover e impulsar al hombre. ¿Es valioso el hombre? Sí. Entonces, démosle la libertad para desarrollarse, para florecer. He aquí el punto de partida del humanismo liberal" (Grondona,

1994, p.174-175).

\section{c) Interpretación del Tribunal Constitucional: libertad personal}

Eran las 11 de la mañana, 2 días para la Navidad, un día más de encierro y no lo podía soportar. Dejamos el gimnasio, y ese día había muchas personas, todas caminaban un poco apuradas, sin mirar a ningún lugar. Apenas nos notaban, una amiga decía que éramos como las pecas de la cara, estamos aquí y sin embargo somos invisibles. Yo tenía mi estrategia lista, solo una puerta me detenía del tubo de metal que va por el toldo para el sol. Esa puerta siempre está cerrada y cuando la dejan junta es porque las personas que la atraviesan dejaron algo al otro lado, lo recogen y vuelven. Solo segundos que no me permitirán cruzar ese ambiente hasta llegar al tubo de metal que puedo trepar. Toda mi infancia la pasé entre los pilotes de la choza de mis abuelos, medían más de 9 metros, y por ahí bajábamos al Amazonas directo al bote. Me escapaba con el Juan, mi primo, y volvíamos a media tarde, él trepaba primero y yo lo seguía, hasta arriba. Astillas se me pegaban, como las hormigas en los pies me han mordido. Pero ya no sentía nada, la piel se 
acostumbra y ya luego, hacíamos competencia. El Juan agarraba el pilote más grueso y yo siempre preferí el delgado con más hoyos. Al comienzo perdía y poco a poco me volví en la más rápida, casi volaba porque ya daba saltos, quería ser como los monos que avanzan dando círculos con las cuatro patas. La cabeza así no puede, por eso iba derecho, apoyaba bien mis pies y empujaba fuerte y rápido. Pero hoy, que salió el sol, veo el tubo verde y oxidado, parece más facilito que el pilote de la casa de mis abuelos. Esa mañana, hacía mucho calor, todos estaban enojados, nadie quería hablar y la madre renegaba, se paseaba con un chico alto y otros iban detrás, sin llaves. La madre era la que abría todas las puertas y no esperaba a que pase todo el grupo, ella entraba rápido sin ver nada más. Miraba por arriba y solo caminaba. Ahí está la oportunidad, avanzaron y dejaron la puerta abierta. Dejé el grupo sin decir nada, caminé de puntas muy rápido y al llegar al marco de la puerta caminé como si me hubieran llamado desde dentro. Di cinco veces los mismos pasos y me pegué a la pared, las hojas pican y las paredes ensucian. Ahí encontré el tubo, y mis piernas saltaron, era más fácil porque el óxido y la pintura verde marcaban surcos en el metal y mis pies se fijaban más rápido sin tanta fuerza. Subí los 12 metros en menos de 20 segundos y encontré los fierros blancos en rombos que agarran el toldo, ahí me enganché y me di la vuelta rápido en el sitio, para que no me vieran. Ahí pasaron las personas otra vez, pero ninguno miraba hacia arriba. No me detuve en ningún momento, solo quería salir. Caminé por el muro lleno de tierra hasta la parte de la columna y de ahí lo mismo para bajar, me agarré fuerte y bajé, fue más difícil pero más rápido. Me dolió al caer, la parte de los pies que llegan antes de mis dedos. De ahí caminé un poco rápido en sentido contrario de la comisaría y subí a una combi ${ }^{19}$. Estaba libre (Poder Judicial, 2013).

Resulta imperativo observar qué es lo que la Constitución establece como Derecho Fundamental a la Libertad. Las sentencias más relevantes del Tribunal Constitucional respecto a la libertad personal, dan luces. Aquel derecho está descrito en el numeral 24 del artículo núm. 2 de la Constitución Política del Perú y el Tribunal Constitucional interpreta (Sentencia Constitucional $\mathrm{N}^{\circ} 2488-2002-\mathrm{HC} / \mathrm{TC}, 2002$ ) que la libertad sirve como fundamento de todos los derechos humanos:

\footnotetext{
${ }^{19}$ Recreación del escape del día 22 de diciembre del año 2013 del Centro Juvenil de Diagnóstico y Rehabilitación de Santa Margarita; relato basado en la información proporcionada por una funcionaria de alto rango de aquel centro juvenil.
} 
10. Los derechos a la vida, a la libertad y a la seguridad personal, constituyen el sustento y fundamento de todos los derechos humanos; por tal razón, su vigencia debe respetarse irrestrictamente, sin que sea moralmente aceptable estipular excepciones o justificar su condicionamiento o limitación. El respeto de ellos y de las garantías para su libre y pleno ejercicio, es una responsabilidad que compete al Estado. En el caso que en el sistema jurídico no se tenga norma explícita que los garantice, se debe adoptar, con arreglo a los procedimientos constitucionales y a las disposiciones de la Convención Americana, las medidas legislativas o de otro carácter que sean necesarias para hacerlos efectivos. Así lo disponen los artículos $1^{\circ}$ y $2^{\circ}$ de la Convención Americana de Derecho Humanos, y el artículo $2^{\circ}$ del Pacto Internacional de Derechos Civiles y Políticos.

(Considerando 10).

Así también, el Tribunal Constitucional (Sentencia Constitucional N5490-2007-HC/TC,

2007) en cuanto a la libertad, puntualiza:

6. Asimismo, este Tribunal no puede dejar de señalar que nuestra Constitución (Art. $1^{\circ}$ : "La defensa de la persona humana y el respeto de su dignidad son el fin supremo de la sociedad y del Estado") y los Tratados Internacionales de Derechos Humanos (CADH, Art. 11 .1: "Toda persona tiene derecho al respeto de su honra y al reconocimiento de su dignidad"; PIDCP, Art. 10 .1: "Toda persona privada de libertad será tratada humanamente y con el respeto debido a la dignidad inherente al ser humano"; DUDH, Art. 10: "Todos los seres humanos nacen libres e iguales en dignidad y derechos $\mathrm{y}$, dotados como están de razón y conciencia, deben comportarse fraternalmente los unos con los otros") no permiten un trato humano degradante y la humillación personal o pública; antes bien, consagran el respeto a la dignidad de la persona humana como la finalidad de la sociedad y el Estado de conformidad con el artículo $1^{\circ}$ de la $\mathrm{CP}$; lo contrario, implica socavar las bases de un orden jurídico vinculado a los derechos humanos.

(Considerando 6).

Asimismo, el Tribunal Constitucional en otra sentencia utiliza criterios de la Corte Suprema de los

Estados Unidos, en el caso Lawrence c. Texas, del 2003 para ampliar sus conceptos sobre libertad:

La libertad protege a la persona de intrusiones gubernamentales arbitrarias en una vivienda u otro lugar privado (...). El derecho de la libertad se extiende más allá de los límites espaciales. La libertad supone una autonomía de la persona que incluye libertad de pensamiento, credo, expresión y cierta conducta íntima. El presente caso involucra la libertad de la persona tanto en su dimensión espacial como en sus más trascendentes dimensiones.

(Como se cita en Sentencia Constitucional Nº6712-2005-HC/TC, 2005, Considerando 42).

Amplía el criterio dicha sentencia, cuando establece que el mecanismo idóneo para defender la afectación de la libertad es el Proceso de Hábeas Corpus:

(...) -en correspondencia con la libertad personal (artículo $2^{\circ}$, inciso 24, de la Constitución)-, en lo referido al derecho a probar (artículo $139^{\circ}$, inciso 3, de la Constitución) y al derecho a la defensa (artículo $139^{\circ}$, inciso 14, de la Constitución). 1. Según la Constitución, todo acto u omisión que vulnere o amenace la libertad personal o algún derecho conexo a ella amerita la presentación de 
una demanda de hábeas corpus por quien se sienta afectado (artículo $200^{\circ}$, inciso 1). Y, tal como lo prescribe el Código Procesal Constitucional, se considerará como derecho conexo a la libertad personal el referido a la tutela procesal efectiva (artículo $4^{\circ}$ ).

(Sentencia Constitucional N${ }^{\circ}$ 712-2005-HC/TC, 2005, Considerando 1)

En adición, dicho Tribunal (Sentencia Constitucional N7039-2005-PHC/TC, 2005) establece una diferencia entre la libertad personal (materia de investigación) y la libertad de tránsito.

15. (...) El ámbito constitucionalmente protegido de la libertad personal es distinto del que se garantiza mediante la libertad de tránsito o de circulación. Este último derecho se encuentra reconocido en el inciso 11) del artículo $2^{\circ}$ de la misma Ley Fundamental, y garantiza a todo peruano a transitar libremente por todo el territorio nacional, y a entrar y salir del país, sin más excepciones que las limitaciones constitucionalmente establecidas. En ese sentido, se objeto es garantizar un aspecto concreto de la libertad física del ser humano, el relativo a su proyección espacial. 16. En cambio, el derecho reconocido en el inciso 24) del artículo $2^{\circ}$ de la Constitución protege la dimensión personal de la libertad física. Garantiza a todos, nacionales o extranjeros, la indemnidad frente a injerencias ilegales o arbitrarias que puedan perturbar el desarrollo de la vida individual, familiar o social. En la STC 019-2005-PI/TC, este Colegiado precisó que: El inciso 24 del artículo $2^{\circ}$ de la Constitución reconoce el derecho fundamental a la libertad personal. Se trata de un derecho subjetivo en virtud del cual ninguna persona puede sufrir una limitación o restricción a su libertad física o ambulatoria, ya sea mediante detenciones, internamientos o condenas arbitrarias. La plena vigencia del derecho fundamental a la libertad personal es un elemento vital para el funcionamiento del Estado social y democrático de derecho, pues no sólo es una manifestación concreta del valor libertad implícitamente reconocido en la Constitución, sino que es presupuesto necesario para el ejercicio de otros derechos fundamentales" (fundamento 11).

(Considerando 15)

Es posible afirmar, que la afectación a la libertad en el supuesto de una fuga sin violencia realizada por un menor sentenciado por cometer una infracción no grave, conlleva un trato arbitrario de parte de la administración del medio cerrado. Toda vez que la conducta de fuga no es tipificada como delito o infracción en el Código Penal, y la sanción administrativa es desproporcional y vulnera el principio de legalidad penal. Ello ocurre debido a que la recaptura de un menor fugado, implica el castigo corporal y el aislamiento superior a los 30 días en el Programa de Intervención Intensiva. Se considera, que una conducta de fuga (amparada por el instinto de búsqueda de la libertad) sin violencia no debe menguar el cuerpo ni la psique del adolescente, ni debe empeorar las condiciones de encierro del recapturado; ya que corresponde a la Administración brindar condiciones idóneas de encierro con programas efectivos de rehabilitación, sin condiciones de hacinamiento. Por ello, es posible deducir que los menores internados en un 
medio cerrado, hacinado, estigmatizado y violento, buscarán la forma más pronta formal o informal de salir.

A su vez, es importante recalcar la diferencia que existe entre privación de libertad y restricción de la libertad. Al respecto el Tribunal Constitucional en la misma sentencia (Sentencia Constitucional $\mathrm{N}^{\circ}$ 7039-2005-PHC/TC, 2005) señala lo siguiente:

17. El ámbito constitucionalmente protegido del derecho a la libertad personal no es ajeno a la existencia de límites internos, es decir, a las restricciones de su ejercicio derivadas del propio contenido del derecho o de sus relaciones con otros bienes constitucionalmente protegidos. En ese sentido, el inciso 24 del artículo $2^{\circ}$ de la Constitución implícitamente diferencia lo que es un supuesto propio de una restricción de la libertad personal, de aquel que constituye una privación de libertad. La diferencia entre privación y restricción es importante a efectos de determinar su régimen jurídico-constitucional pues, como se acotó en la STC 02050-2002-AA/TC, (...) tal garantía de la libertad personal (orden judicial o flagrante delito) no se extiende a cualquier supuesto de restricción, sino que está directamente relacionada con la "detención" de una persona, es decir, con medidas que supongan una privación de la libertad. Evidentemente, ese no es el caso ni del denominado arresto simple ni del denominado arresto de rigor, que más bien constituyen o implican una restricción de la libertad. Y para ambos, no es de aplicación el ordinal "f" del inciso 24) del artículo $2^{\circ}$ de la Constitución, sino su ordinal "b", a tenor del cual "No se permite forma alguna de restricción de la libertad personal, salvo en los casos previstos por la ley"(...).

(...) Así, pues, desde esta perspectiva, el derecho a la libertad personal garantiza, en su faz negativa, que nadie pueda ser restringido en su libertad personal sino por las causas o circunstancias expresamente tipificadas en la ley y con estricta sujeción a los procedimientos objetivamente definidos por ella.

(Considerando 17).

Por tanto, el legislador al no prohibir la conducta fuga, ha proporcionado que dicha acción se constituya en un comportamiento no antijurídico (es decir tolerado) esto es jurídico; es decir, acorde a derecho. Bajo ese supuesto, no debe corresponder sanción de ningún modo al adolescente que fuga; salvo que hubiera perpetrado infracciones en el momento de la fuga. Se debe entender, que las medidas administrativas que se desarrollan para la recaptura del adolescente que fugó del medio cerrado, no deben generar el receso en el programa resocializador que desarrolla el adolescente al momento de la fuga.

En ese sentido, y respecto a la restricción de la libertad dicho Tribunal (Sentencia Constitucional $\mathrm{N}^{\circ}$ 7039-2005-PHC/TC, 2005) señala que:

b) Adicionalmente a la necesidad de que las causas y el procedimiento para restringir la libertad personal de una persona estén contempladas en la ley, este Tribunal recalca la exigencia constitucional de que dicha restricción legalmente establecida de la libertad sea compatible con el respeto del contenido constitucionalmente protegido de los derechos fundamentales. 
En efecto, parafraseando a la Corte Interamericana de Derechos Humanos, este Tribunal considera que nadie puede ser sometido a una restricción de su libertad física (...) por causas y métodos que -aun calificados de legales- pueda reputarse como incompatibles con el respeto de los derechos fundamentales del individuo por ser, entre otras cosas, irrazonables, imprevisibles, o faltos de proporcionalidad [12].

De modo que una restricción legalmente válida de la libertad física de las personas no impide que ésta pueda ser considerada como arbitraria, si es que se presenta como irrazonable o desproporcionada.

19. La prohibición de privar del ejercicio de la libertad o, en su caso, de restringirla ilegal o arbitrariamente, vincula tanto al Estado como a los propios particulares.

(Considerandos 18 y 19).

De aquel texto, se concluye que la restricción de la libertad se lleva a cabo en un medio idóneo con respeto y armonía sobre los derechos fundamentales. Es posible por tanto afirmar, que la recaptura, golpiza y aislamiento en el Programa de Intervención Intensiva son arbitrarias, toda vez que devienen en irrazonables y desproporcionadas; atendiendo al deseo de libertad frente a las condiciones de internamiento en un Centro Juvenil violento y hacinado.

Resulta apropiado ampliar el argumento señalado por la Sentencia de 24 de enero de 1998 de la Corte Interamericana de Derechos Humanos, Caso Gangaram Panday vs Surinam (Sentencia de 21 de enero de 1994):

(...) garantías específicas, descritas en sus incisos 2 y 3, la prohibición de detenciones o arrestos ilegales o arbitrarios, respectivamente. Según el primero de tales supuestos normativos, nadie puede verse privado de la libertad personal sino por las causas, casos o circunstancias expresamente tipificadas en la ley (aspecto material), pero, además, con estricta sujeción a los procedimientos objetivamente definidos por la misma (aspecto formal). En el segundo supuesto, se está en presencia de una condición según la cual nadie puede ser sometido a detención o encarcelamiento por causas y métodos que -aún calificados de legales- puedan reputarse como incompatibles con el respeto a los derechos fundamentales del individuo por ser, entre otras cosas, irrazonables, imprevisibles, o faltos de proporcionalidad.

(Considerando 47).

El Tribunal Constitucional (Sentencia Constitucional N010-2002-AI/TC, 2002) analiza el numeral 22 del artículo núm. 139 de la Constitución, ya que aquel artículo determina la finalidad y función de la restricción de la libertad.

179. Al margen de la ardua polémica sobre el tema de los fines de la pena, es claro que nuestro ordenamiento ha constitucionalizado la denominada teoría de la función de prevención especial positiva, al consagrar el principio según el cual, el "régimen penitenciario tiene por objeto la reeducación, rehabilitación y reincorporación del penado a la sociedad", en armonía con el artículo 10.3 del Pacto Internacional de Derechos Civiles y Políticos, que señala que "el régimen 
penitenciario consistirá en un tratamiento cuya finalidad esencial será la reforma y la readaptación social de los penados".

180. Se trata, naturalmente, de un principio constitucional-penitenciario, que no por su condición de tal, carece de eficacia. Comporta, por el contrario, un mandato de actuación dirigido a todos los poderes públicos comprometidos con la ejecución de la pena y, singularmente, al legislador, ya sea al momento de regular las condiciones cómo se ejecutarán las penas...

(Considerandos 179 y 180).

Respecto a las exigencias establecidas por la Constitución, el propio Tribunal Constitucional (Sentencia Constitucional $\mathrm{N}^{\circ} 010-2002-\mathrm{AI} / \mathrm{TC}, 2002$ ), también se refiere a la dignidad y a la prohibición de inocuización del joven en conflicto con la ley penal. El Colegiado considera que los menores infractores no deben ser tratados como instrumentos nocivos, ni que la sociedad deba primordialmente contener y alejar; es la comunidad la encargada de cuidar, ayudar y rehabilitar a estos jóvenes:

186. En segundo lugar, este Colegiado considera que detrás de las exigencias de "reeducación", "rehabilitación" y "reincorporación" como fines del régimen penitenciario, también se encuentra necesariamente una concreción del principio de dignidad de la persona (artículo $1^{\circ}$ de la Constitución) y, por tanto, éste constituye un límite para el legislador penal. Dicho principio, en su versión negativa, impide que los seres humanos puedan ser tratados como cosas o instrumentos, sea cual fuere el fin que se persiga alcanzar con la imposición de determinadas medidas, pues cada uno, incluso los delincuentes, debe considerarse como un fin en sí mismo, por cuanto el hombre es una entidad espiritual moral dotada de autonomía.

187. En el ámbito penitenciario, la proyección del principio de dignidad comporta la obligación estatal de realizar las medidas adecuadas y necesarias para que el infractor de determinados bienes jurídicos-penales pueda reincorporarse a la vida comunitaria, y que ello se realice con respeto a su autonomía individual, cualquiera sea la etapa de ejecución de la pena. Sin embargo, y aunque no se exprese, detrás de medidas punitivas de naturaleza drástica (...) subyace una cosificación del penado, pues éste termina considerado como un objeto de la política criminal del Estado, (...).

188. El carácter rehabilitador de la pena tiene la función de formar al interno en el uso responsable de su libertad. No la de imponerle una determinada cosmovisión del mundo ni un conjunto de valores que, a lo mejor, puede no compartir.

(Considerandos 186-188).

La misma sentencia (Sentencia Constitucional $\mathrm{N}^{\circ} 010-2002-\mathrm{AI} / \mathrm{TC}$, 2002), resulta especialmente relevante para el presente estudio pues en ella se analiza una de las características de la Remisión: Oportunidad.

193. Por otro lado, también el legislador nacional puede introducir un régimen legal especial en materia de beneficios penitenciarios, de manera que se posibilite la realización efectiva de los principios de dignidad de la persona y resocialización. Ese es el caso, por ejemplo, de la legislación italiana, que, con el objeto de que la cadena perpetua pueda ser compatibilizada con los principios 
de resocialización y de dignidad de la persona, a través de la Ley N. ${ }^{\circ} 663$ del 10 de octubre de 1986 ha posibilitado que, luego de quince años de prisión, el condenado pueda acceder al beneficio de la semilibertad y, luego, a la libertad condicional. Similar situación sucede en la mayoría de países europeos y también en algunos latinoamericanos (...).

(Considerando 193).

Por tanto, constituye una acción propia del Estado (cuando encuentra una deficiencia en su actuación), brindar beneficios y oportunidades a sus administrados, para alcanzar las características que propone el Principio de Humanidad de las penas. Para que la finalidad penitenciaria se cumpla a cabalidad y en armonía con los principios internacionales que resguardan el respeto a los Derechos Fundamentales.

Es importante también abordar el análisis sobre la Proporcionalidad de las penas o infracciones:

195. El principio de proporcionalidad es un principio general del derecho expresamente positivizado, cuya satisfacción ha de analizarse en cualquier ámbito del derecho. En efecto, en nuestro ordenamiento jurídico, éste se halla constitucionalizado en el último párrafo del artículo 200 de la Constitución. En su condición de principio, su ámbito de proyección no se circunscribe sólo al análisis del acto restrictivo de un derecho bajo un estado de excepción, pues como lo dispone dicha disposición constitucional, ella sirve para analizar cualquier acto restrictivo de un atributo subjetivo de la persona, independientemente de que aquel se haya declarado o no. Y las penas, desde luego, constituyen actos que limitan y restringen esos derechos de la persona.

197. En la medida que el principio de proporcionalidad se deriva de la cláusula del Estado de Derecho, él no sólo comporta una garantía de seguridad jurídica, sino también concretas exigencias de justicia material. Es decir, impone al legislador el que, al momento de establecer las penas, ellas obedezcan a una justa y adecuada proporción entre el delito cometido y la pena que se vaya a imponer. Este principio, en el plano legislativo, se encuentra en el artículo VII del título preliminar del Código Penal, que señala que "la pena no puede sobrepasar la responsabilidad por el hecho (...)".

199. Corresponde al ámbito del legislador, al momento de determinar las penas, evaluar factores tales como la gravedad del comportamiento o la percepción social relativa a la adecuación entre delito y pena. Mientras que a dicho órgano le corresponde evaluar los elementos y circunstancias antes señaladas y de conformidad con ellas, establecer, entre otros supuestos, las penas aplicables para determinados delitos; al Tribunal Constitucional, en cambio, le corresponde indagar si los bienes o intereses que se tratan de proteger son de naturaleza constitucional y por tanto, son socialmente relevantes; asimismo, evaluar si la medida es idónea y necesaria para alcanzar los fines de protección que se persiguen, por no existir otras penas menos aflictivas de la libertad y, finalmente, juzgar si existe un desequilibrio manifiesto, esto es, excesivo o irrazonable entre la sanción y la finalidad de la norma.

(Sentencia Constitucional Nº10-2002-AI/TC, 2002, Considerandos 195-199).

El último aspecto desarrollado por la sentencia (Sentencia Constitucional N010-2002-AI/TC, 2002, considerando 199), reconoce un problema cuando identifica a la percepción social como un 
factor que coadyuva a la determinación de las penas. Ello debido a que la opinión pública se forma por la información que recibe de los medios de comunicación (Raymond, 2011). La prensa en el Perú pierde objetividad cuando sus objetivos pecuniarios se acercan, también pierde fidelidad cuando lo comunicado es verificado por su director con una definida postura política. Por tanto, se crea incertidumbre, una continua repetición de crímenes violentos (a todo horario).

\section{Figura 5.1}

Población de 15 y más años de edad del área urbana, víctima de algún
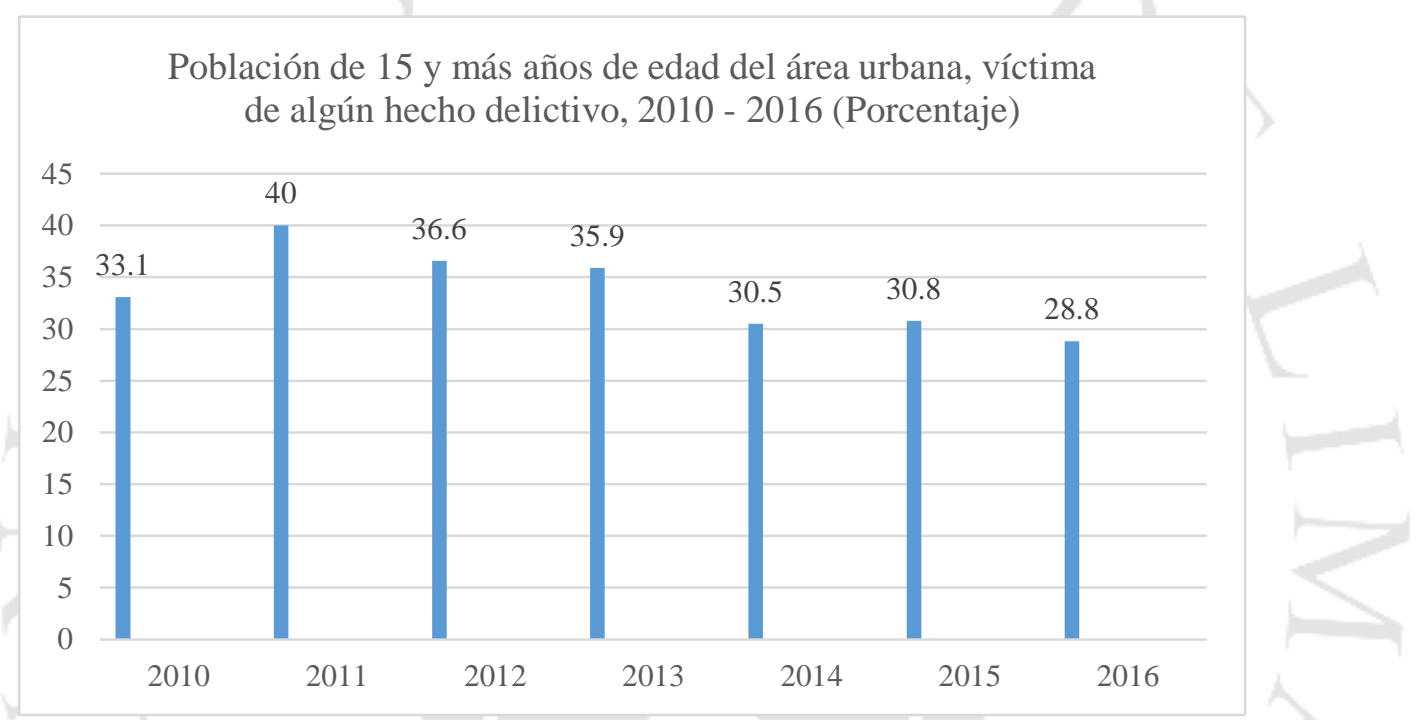

Fuente: Instituto Nacional de Estadística e Informática - Encuesta Nacional de Programas Presupuestales $2010-2016$

Esta figura demuestra la incidencia delictiva del país, y la desproporción que existe respecto a la alta percepción de criminalidad que mantienen los peruanos.

Podemos observar que a partir del año 2011, la incidencia de los actos delictivos están disminuyendo de manera progresiva. Con excepción del año 2015 donde el índice tiene un incremento de 0,3\%. Según la estadística presentada en la interpelación al titular del Ministerio del Interior en el Congreso de la República el mes de junio del 2017, se demostró la disminución del crimen entre los años 2015 y 2017. En ese sentido, para agosto del 2015 y abril del 2016, existía un ratio de criminalidad de $32,7 \%$. No obstante, el ratio para los meses, agosto 2016 y abril del 2017 disminuye, toda vez que el porcentaje alcanzado es de 26,5\%; es decir, en un solo año, la 
criminalidad se redujo un 6.2\%. Pese a estas cifras oficiales presentadas en el Congreso de la República, no existió ningún informe de la prensa con un mensaje que muestre estos índices.

Figura 5.2.

Robos o intento de robo en la vivienda en el Perú

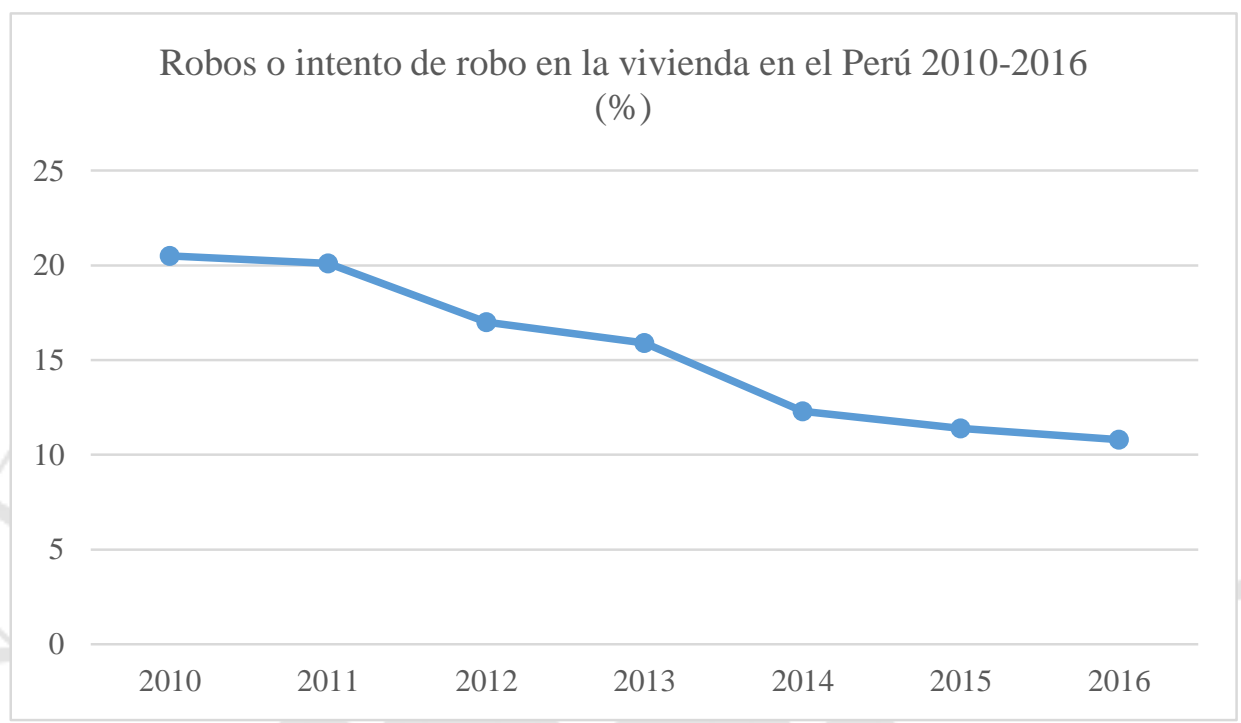

Fuente INEI. Encuesta Nacional de Programas Estratégicos (ENAPRESS).

A su vez, los Robos en las viviendas del Perú, también han disminuido. De manera progresiva y constante, se han reducido casi en la mitad desde el año 2010.

\section{Figura 5.3.}

Población de 15 y más años de edad del área urbana, con percepción de inseguridad en los próximos doce meses, 2010 - 2016

Población de 15 y más años de edad del área urbana, con percepción de inseguridad en los próximos doce meses, 2010

$$
-2016
$$

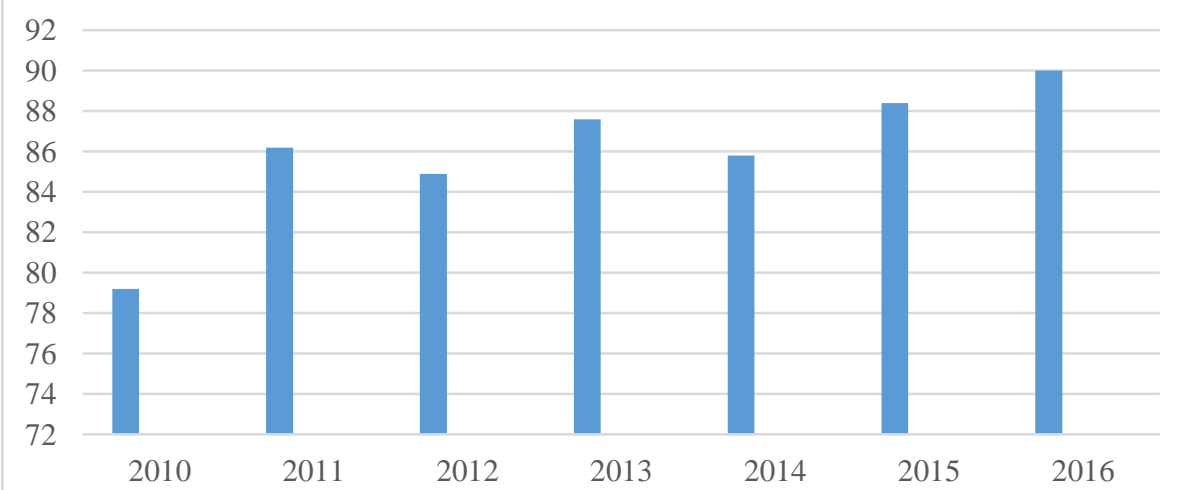

Fuente: INEI. Encuesta Nacional de Programas Presupuestales 2010-2016. 
Pese a que la incidencia delictiva está disminuyendo, la percepción de la Sociedad es contraria. Para el año 2016 el 90\% de los peruanos sostienen que podrán ser víctimas de actos derivados de la inseguridad ciudadana. Esta situación se mantiene para el año 2017, ya que para abril del año 2017 la percepción de inseguridad es muy próxima al 90\% (89.1\%).

\section{Figura 5.4.}

Tasa de homicidios en Latinoamérica 2014 (Por cada cien mil habitantes)

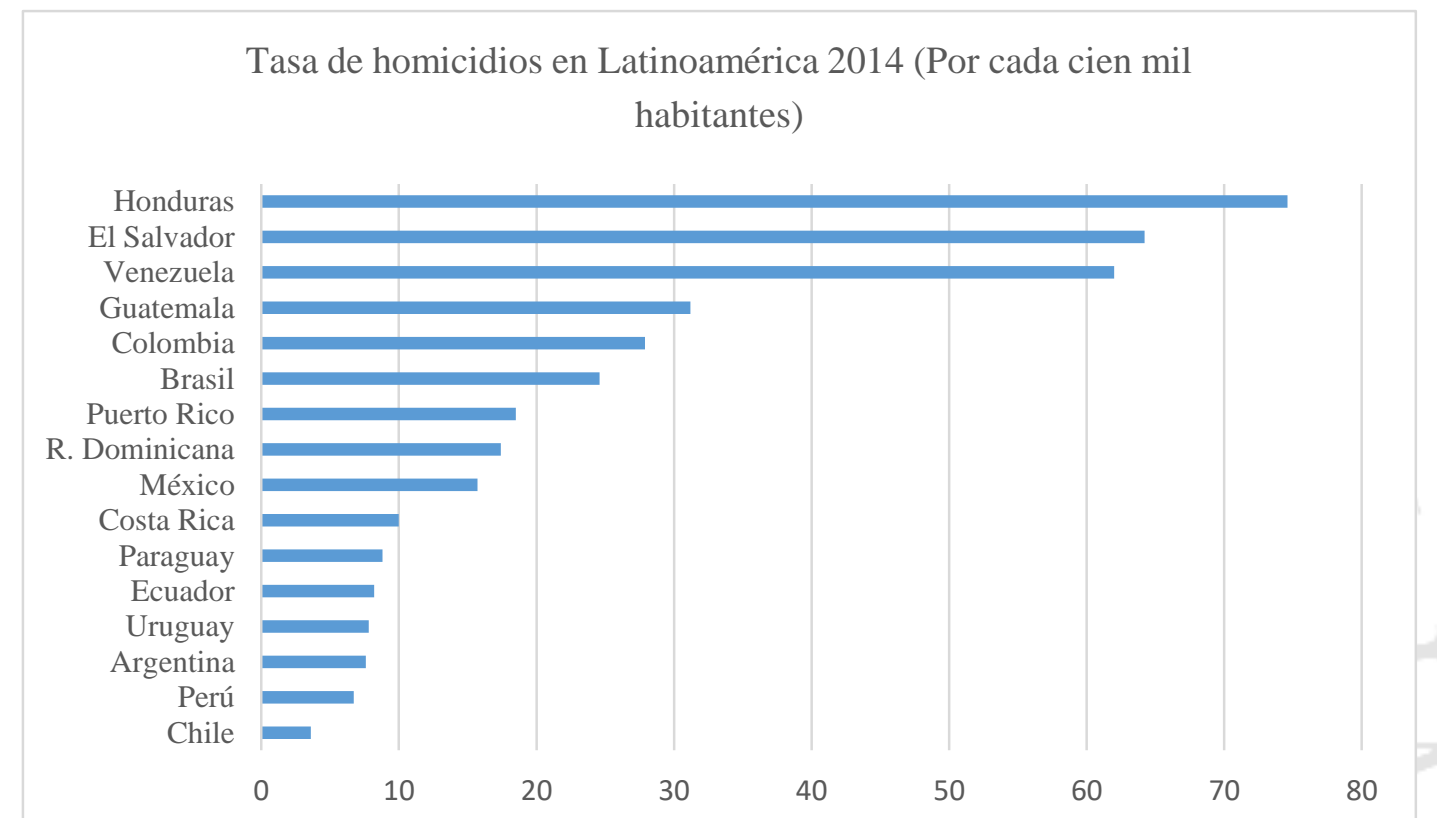

Fuente: Consejo Nacional de Política Criminal (2017) ¿Qué sabemos de los homicidios en el Perú? 
Figura 5.5.

Percepción Promedio de inseguridad por país, 2014

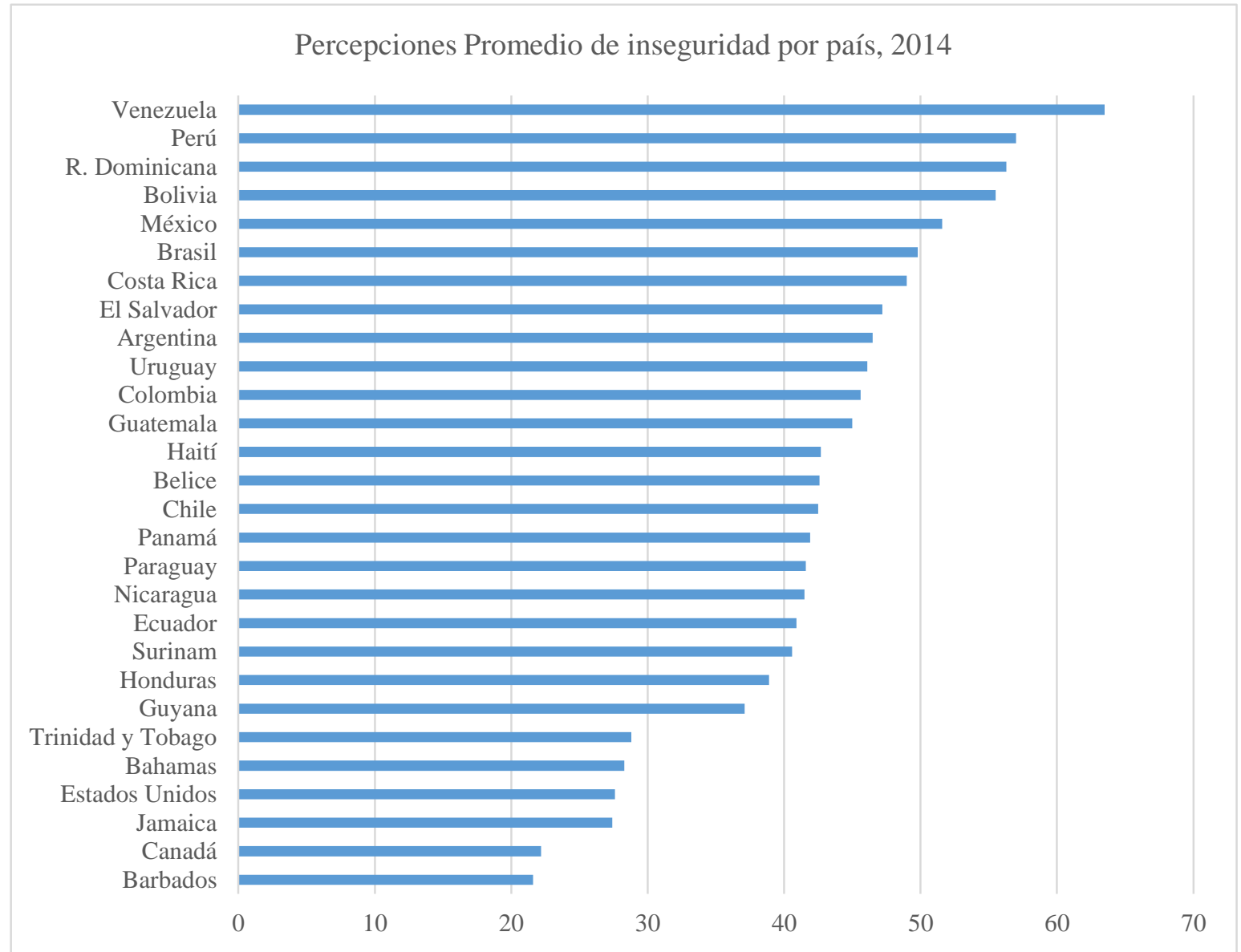

Percepción de Inseguridad. 95\% Intervalo de confianza. Fuente: Barómetro de las américas por LAPOP, 2014; v.GM14_3.0.

Producto de la opinión pública, influenciada por el mass media (medios de comunicación), la percepción de inseguridad en el Perú casi lidera la lista a escala Latinoamericana. No obstante, veremos en el siguiente cuadro que el Perú es el último país donde se cometen actos violentos que atentan contra la vida y es ubicado como uno de los países más seguros dentro de América Latina.

Finalmente, la evaluación y estudio que hace el Tribunal Constitucional sobre la libertad, mantiene correspondencia y concordancia con las finalidades de la Justicia Restaurativa. En ese sentido, aquella sentencia del Tribunal Constitucional (Sentencia Constitucional Nº10-2002-AI/TC, 2002) refuerza lo desarrollado: 
208. (...) Dentro de la condiciones cómo se ejecutará la pena, se encuentra, desde luego, la posibilidad de que el legislador autorice la concesión de determinados beneficios penitenciarios, pues ello obedece y es compatible con los conceptos de reeducación y rehabilitación del penado. En ese sentido, el Tribunal Constitucional considera que estos principios suponen, intrínsecamente, la posibilidad de que el legislador pueda autorizar que los penados, antes de la culminación de las penas que les fueron impuestas, puedan recobrar su libertad si los propósitos de la pena hubieran sido atendidos. La justificación de las penas privativas de libertad es, en definitiva, proteger a la sociedad contra el delito. Tal protección sólo puede tener sentido, "si se aprovecha el periodo de privación de libertad para lograr, en lo posible, que el delincuente una vez liberado no solamente quiera respetar la ley y proveer a sus necesidades, sino también que sea capaz de hacerlo".

(Considerando 208).

\section{d) Las fugas (evasiones del encierro)}

Un alto funcionario de la Gerencia de los Centros Juveniles encuentra tres razones que determinan

o empujan al menor a fugarse: El instinto, la oportunidad y el planeamiento de fuga. En realidad, los dos primeros son razones y el último es el método.

\section{Figura 5.6.}

Fugas Producidas a nivel nacional en el año 2010

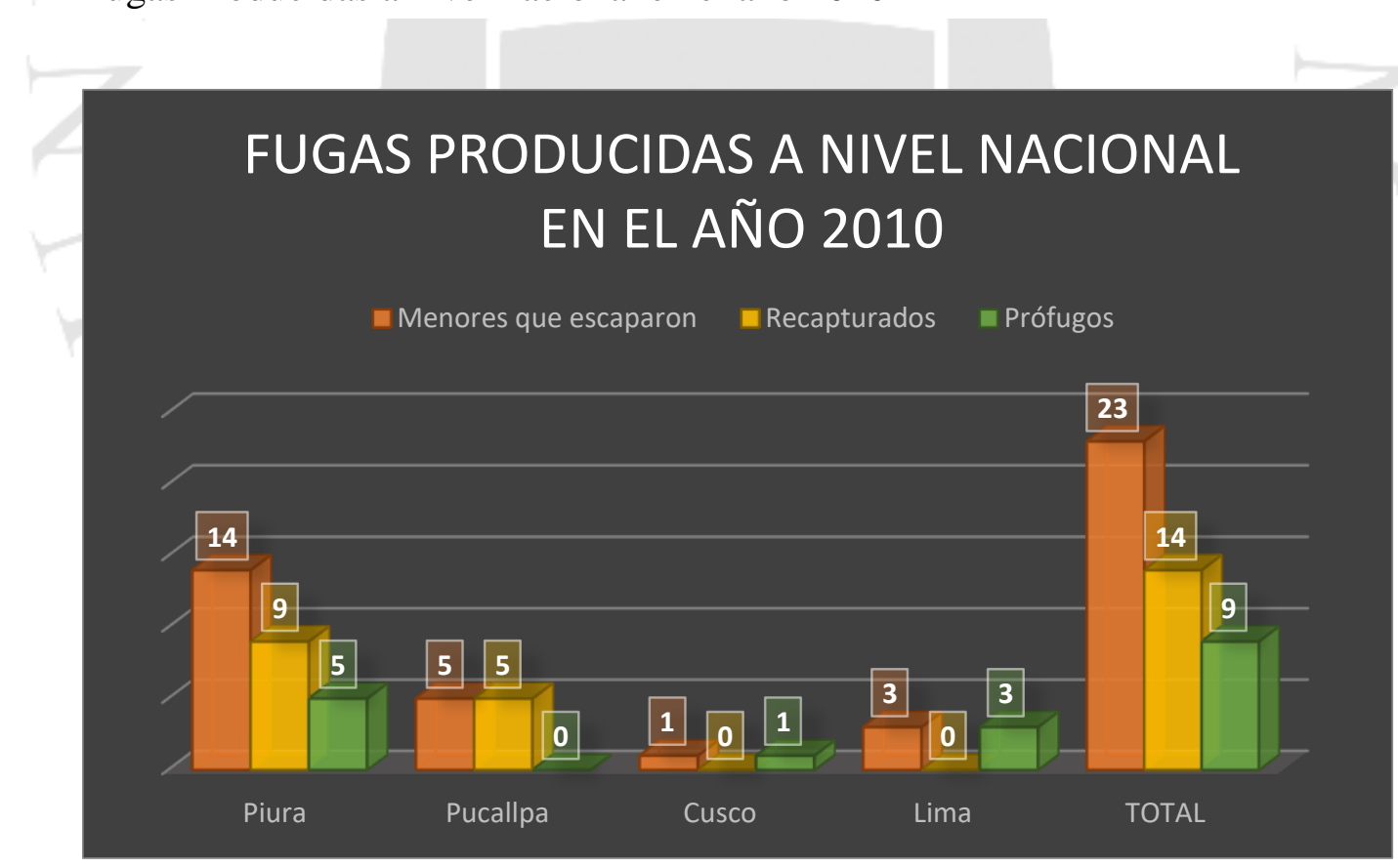

Fuente: Datos obtenidos por la Oficina Administrativa del Poder Judicial encargada de administrar los Centros Juveniles de Diagnóstico y Rehabilitación a nivel nacional.

Para el año 2010, a nivel nacional se fugaron 23 jóvenes, de ese total 14 fueron recapturados y 9 quedaron prófugos. Piura fue la provincia con mayor incidencia de fugas para aquel año. 
Figura 5.7.

Fugas Producidas a nivel nacional en el año 2011

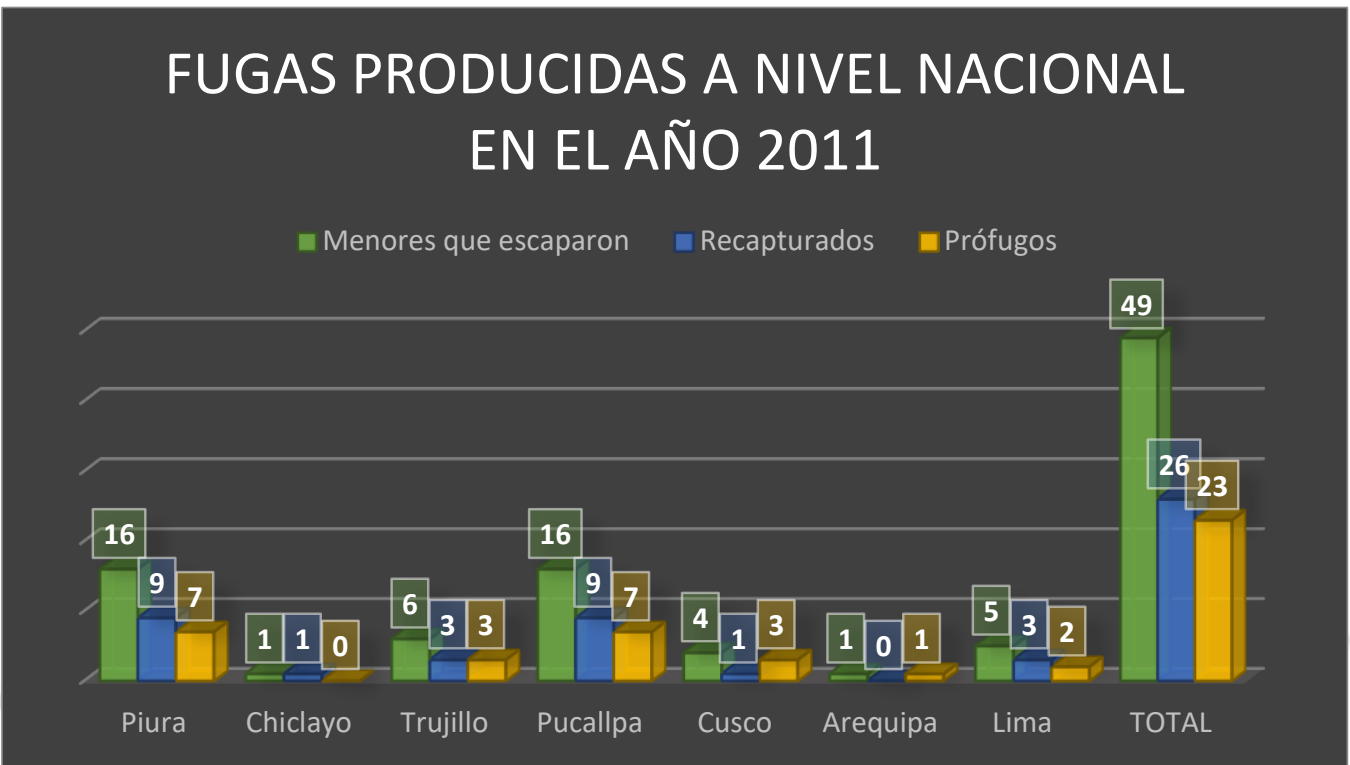

Fuente: Datos obtenidos por la Oficina Administrativa del Poder Judicial encargada de administrar los Centros Juveniles de Diagnóstico y Rehabilitación a nivel nacional.

Un año después, para el 2011, el ratio en las fugas se incrementó en más del doble, pues de solo 23 en el año 2010, se produjeron en el año siguiente 49 fugas a escala nacional.

Como se explicó en los anteriores capítulos, el instinto de búsqueda de la libertad es consustancial a la condición humana y se refuerza con el encierro. No se puede evitar, la resignación a perder la libertad es cuestionar el instinto, es una postura que se adopta. Se explica entonces, que desde el momento en el que un menor ingresa en a un Centro Juvenil de Diagnóstico y Rehabilitación, esté observando la manera de liberarse del enclaustramiento; es más, desde el momento que saben que van a ir a uno de estos centros, solo piensan en una cosa: escapar. 
Figura 5.8.

Fugas Producidas a nivel nacional en el año 2012

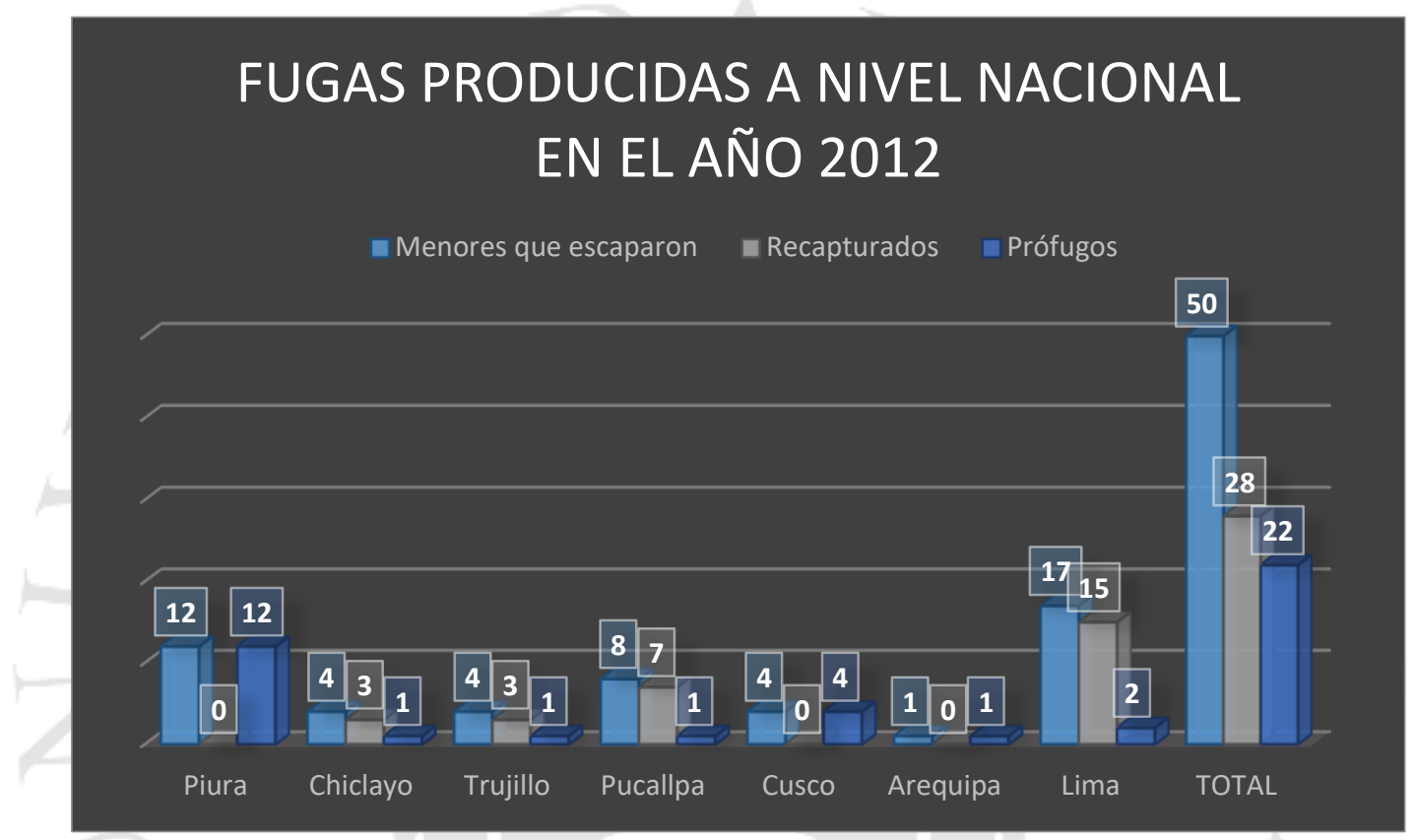

Fuente: Datos obtenidos por la Oficina Administrativa del Poder Judicial encargada de administrar los

Centros Juveniles de Diagnóstico y Rehabilitación a nivel nacional.

Asimismo, para el año 2012 el número se mantiene, se incrementó de manera muy leve (en una persona). El promedio anual de las evasiones a nivel nacional hasta el 2014 era de 50 adolescentes. Este gran promedio causó el incremento en la vigilancia y mejora de infraestructura de los centros para menores. El desencadenante de estas modificaciones fue, en gran medida, el escape de gran cobertura mediática de uno de los principales sicarios menores que se tenía en cautela. En la víspera del año nuevo y en el primer día del año 2013, se escaparon un total de 27 menores, dentro de ellos Alexander Pérez (El Comercio, 3 de agosto de 2014), conocido como Gringasho. ${ }^{20}$

\footnotetext{
${ }^{20}$ El historial de Alexander Manuel Pérez Gutiérrez, conocido como 'Gringasho', se remonta al 2010 cuando con tan solo 15 años fue internado en un Centro de Rehabilitación Juvenil de Trujillo, acusado del homicidio de Deysi García Tooh. Fue liberado meses después por falta de pruebas, aunque a partir de entonces lo que siguió fue una serie de fugas, medidas socio educativas de internamiento y más infracciones.

En setiembre del 2011, 'Gringasho' fue arrestado por el asesinato de tres personas en el distrito de El Porvenir y cuatro meses después, condenado a seis años de internamiento en medio cerrado por estar involucrado en diversos casos de sicariato. Esto no fue impedimento para el ímpetu delictivo del joven delincuente, quien logró escapar del reclusorio de Trujillo junto a otros tres menores en abril del 2012.
} 
Ese escape no todos los menores tenían el mismo perfil infractor que "Gringasho", muchos de ellos estaban encerrados por infracciones no violentas y/o enfermos con alguna adicción. Esta distinción resulta relevante para la limitación de la evasión no punible, pues se podrá aplicar este recurso solo en aquellos menores que cometieron infracciones no violentas. El criterio (desarrollado en otro capítulo) Necesidad/Utilidad es la base para determinar la aplicación de este recurso.

En ese escape violento de "Gringasho", las órdenes provenientes desde el Poder Ejecutivo fueron de encontrar a cada uno de los menores; la operación sólo sería considerada como exitosa cuando se encuentre al joven sicario. Las soluciones que se intentaron a partir de ese suceso resultaron más contraproducentes que acertadas, ya que el Instituto Nacional Penitenciario (INPE) alberga actualmente en sus instalaciones a jóvenes infractores menores de edad en espacios que carecen de los programas rehabilitadores para adolescentes, talleres y escuela.

Este convenio permite que el INPE otorgue un espacio en una de sus prisiones de mayor seguridad en Lima, se brinda ambientes para alojar a los menores infractores. Sin embargo, no se pueden utilizar otros ambientes destinados al programa resocializador; no se pueden utilizar las instalaciones como talleres, patios deportivos, etc.

Los programas resocializadores y rehabilitadores para jóvenes en conflicto con la ley penal no se pueden implementar, la infraestructura y la naturaleza del convenio lo imposibilita. Es un espacio de albergue, donde los infractores reciben a un psicólogo de manera rutinaria y una pequeña instrucción en bisutería. No reciben el programa necesario para reinsertarse en la sociedad. Encierro más severo con menos tratamiento rehabilitador.

En el medio cerrado común para adolescentes infractores, la finalidad está dirigida a la educación del joven; ese ánimo se denota en la prohibición del uso de armas de fuego y en la poca seguridad especializada para evitar escapes. Sin embargo, a raíz de aquel suceso, donde escapó el

\footnotetext{
'Gringasho' se trasladó a Lima junto a su enamorada Yazmin Marquina Casas, quien también cobraría protagonismo por su cercanía con el hampa, y ambos se hospedan en un hotel de Los Olivos. Allí fue recapturado por la policía el 12 de junio del 2012. En medio de su reclusión de cinco años en el Centro Juvenil de Diagnóstico y Rehabilitación de Lima 'Maranguita', 'Gringasho' aprovechó el descuido de los agentes de seguridad y fugó por segunda vez junto a otros doce menores.

Un mes después la policía logró capturarlo en Santa Anita. Tras cumplir la mayoría de edad, en mayo del 2013, el sicario fue internado en el penal de Piedras Gordas II.

De acuerdo con un examen psicológico, realizado en enero del 2013, se determinó que Alexander Manuel Pérez Gutiérrez es "emocionalmente impulsivo, violento, insensible al dolor humano, desafiante, calculador y egocéntrico", características por las que lo calificaron como un sujeto con "alto grado de peligrosidad social" (El Comercio, 2014)
} 
"Gringasho", la seguridad de los centros juveniles fue mejorada con la finalidad de reducir los índices de evasión. Por ello, se debe resaltar a Piura, ya que ocurrieron muchas fugas durante los años 2010, 2011 y 2012.

\section{Figura 5.9.}

Estadística de escapes en Piura

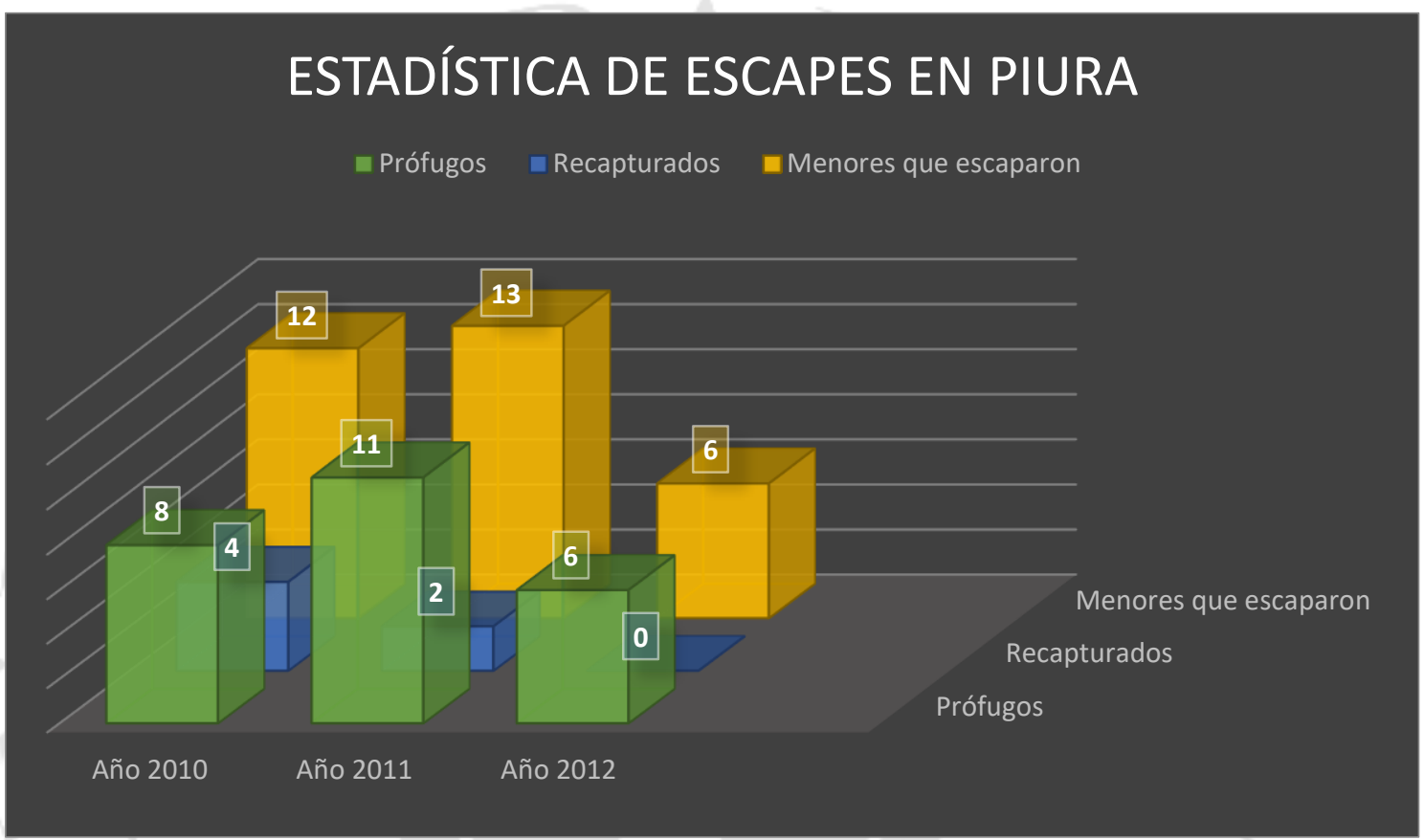

Fuente: Datos obtenidos por la Oficina Administrativa del Poder Judicial encargada de administrar los Centros Juveniles de Diagnóstico y Rehabilitación a nivel nacional.

Este cuadro nos coloca en varios supuestos: En primer lugar, los menores que logran con efectividad fugarse no son pocos. El Estado no se preocupaba (al menos en los años, 2010-2012) por recapturarlos. La Administración carece de recursos para hacerlo. Los menores que fueron recapturados, son aquellos que volvieron acompañados de sus padres; conocen las consecuencias nefastas que se desencadenan cuando un menor es recapturado.

Es necesario resaltar que, y con mucha sorpresa, los menores que estaban internados por cometer una infracción sin violenta, que además viven con sus padres, y sin presencia de agresividad ni contacto intenso y duradero con otros infractores juveniles; resultan ingresados nuevamente al clima hostil que existe en los centros de resocialización para menores. Nuevamente internados en la escuela de aprendizaje del mal (recordando a Foucault). 
Aquel escenario preocupante, pero real, es el de nuestro país. En estos momentos donde se asienta la idea de la prevención antes que el castigo; debemos también evitar el Contacto Diferencial. En ese sentido, rechazar el contagio, también se considera como una medida preventiva. Se evita que el menor siga interactuando con otros que efectuaron infracciones violentas, se intenta alejarlo del mundo de la violencia. La oportunidad única, que fue abierta por una situación y un anhelo, se debe aprovechar para que el medio no lo envuelva y lo transforme negativamente dándole las herramientas necesarias para avanzar en la formación criminal.

Las fugas de estos centros de menores, son una alternativa que se puede aprovechar para aquellos adolescentes, internados en un medio cerrado, que vulneraron conductas prohibitivas sin violencia; ello con la finalidad de que reciban un tratamiento de reinserción en la sociedad, a diferencia del tratamiento que reciben alejados de la comunidad.

\section{2.- Un desafío para el moralismo legal}

El contexto social actual cree que la utilización de la medida de internamiento en medio cerrado para los menores infractores de la ley penal implica siempre un beneficio. Férreamente la sociedad cree que el "almacenamiento de criminales" implica un beneficio directo: se aleja el mal de la sociedad, se impone mano dura, condenas largas, un sentimiento momentáneo de paz. En aquel contexto -y para bien del mundo criminal-, no se toman en consideración las consecuencias perniciosas de esta práctica.

Las medidas socio educativas mantienen un lapso de duración, el adolescente será egresado del encierro sea que se rehabilite o que no, o que se perfeccione en la infracción en camino hacia el delito. Primero interesa rehabilitar; es más económico rehabilitar hoy, que encerrar mañana.

El moralismo legal imperante en nuestro tiempo y espacio, asume que "no es adecuado dar libertad al que fuga". Las personas que defienden estos propósitos no conocen que esta mecánica produce menos beneficios y más contrariedades; se observa solo un ángulo del problema y lo demás queda pendiente de manera indefinida. En consecuencia, este trabajo ayuda a eliminar el prejuicio que se mantiene sobre el camino del joven transgresor: se observan sus orígenes, mecanismos de acción y consecuencias. El afán es brindar una opción para disminuir la futura producción de criminales.

Quedaron olvidadas las enseñanzas de Montesquieu que señaló la necesidad de limitar el ejercicio de la función legislativa: “toda pena que no derive de la necesidad es tiránica. La ley no 
es un puro acto de poder; las cosas indiferentes por su naturaleza no son de su incumbencia" (Montesquieu, 1906, p.450).

La sociedad considera que albergar personas que cometen actos criminales en centros penitenciarios (se incluyen los Centros Juveniles de Diagnóstico y Rehabilitación) genera beneficios; por tanto, si algún joven infractor escapa de estos lugares automáticamente se genera un perjuicio. Sin embargo, no se toma en cuenta que la medida socio-educativa de internamiento en medio cerrado envuelve al menor en un ambiente hacinado, violento y poco atendido por el Estado (Roxin, 2000).

Es ineficiente la administración del encierro carcelario y sus sucedáneos en el Perú. El moralismo legal de nuestra época es útil para enseñar los efectos perjudiciales que presentan los centros de internamiento en medio cerrado para menores del país; por el contrario, los envuelve con un manto del silencio y la indiferencia. Los juicios morales son posiciones guiadas por las coyunturas de tiempo y espacio, suponen mutaciones constantes y periódicas. En cambio, hechos, situaciones y las medidas determinan una realidad: los centros reformatorios de conductas deben hallar alternativas de solución "El control jurídico no debe suponer que mediante cláusulas de intangibilidad se excluya definitivamente de la investigación un campo del conocimiento (...). No hay cosas que no se puedan hacer, sino que hay cosas que no se pueden hacer en un momento determinado por razones éticas y técnicas" (Ramiro Avilés, s.f.).

El poder de perdonar tiene los inconvenientes de hacer inciertas las penas, y dueño de la vida de todos al que ejerce semejante derecho. Los perdones no motivados, que son efecto del favor o de la facilidad del príncipe, acusan a las leyes y al gobierno: a las leyes de ser crueles con los individuos; al gobierno de ser cruel con el público. Es necesario que la razón, la justicia y la humanidad falten en alguna parte; porque la razón no está en contradicción con ella misma, la justicia no puede destruir con una mano lo que hace con la otra, la humanidad no puede ordenar que se establezcan penas que protejan la inocencia, y se concedan perdones que fomenten el delito. Se dice que la clemencia es la primera virtud de un príncipe: sin duda lo es, cuando se trata de un delito que consiste en una ofensa hecha a su amor propio; cuando el delito es contra la sociedad, el perdón ya no es un acto de clemencia, sino una verdadera prevaricación. En los casos en que la pena haría más mal que bien, como después de algunas sediciones o conspiraciones, el poder de perdonar no es solamente útil, sino necesario; pero estos casos deben estar previstos en un buen sistema legislativo, y entonces el perdón no es violación, sino una ejecución de la ley. En suma: si las leyes son demasiado duras, el poder de perdonar es un correctivo necesario; pero este correctivo es también un mal. Haced buenas leyes, y no inventéis una varita de virtudes que tenga el poder de anularlas. Si la pena es necesaria, no se debe perdonar; si no es necesaria, no debe imponerse.

(Bentham, 1839, pp.71-72). 
El habilitar un supuesto adicional de remisión (desarrollada en el Capítulo VIII) no daña bienes jurídicos fundamentales. Así tampoco coloca en disputa derechos constitucionales, más bien asume los instintos como parte de la condición humana para encontrar una solución ex post que evita el contagio en un medio de reclusión, que por no cubrir los estándares razonables deviene en nocivo. La propuesta enfrenta a la administración del medio cerrado, para conseguir mejores resultados, es una medida óptima para la circunstancia que vivimos. El progreso del derecho se funda en la búsqueda de soluciones jurídicas a los problemas nuevos, o a los añejos no resueltos, aparentemente resueltos, o que por haber mutado quedaron fuera del alcance de las soluciones que antes eran idóneas.

En ese sentido, la realidad enseña que existirán más fugas de los Centros Juveniles de Diagnóstico y Rehabilitación, salvo que el encierro sea más severo, lo que, sin atención debida e infraestructura suficiente, sería más dramático que hoy. Por ello es necesario idear opciones acertadas frente a este fenómeno. No ocasionar efectos contraproducentes, como los de volver a encerrar a un menor no violento que fuga sin violencia y que no representa un peligro para la sociedad; recapturarlo, golpearlo y encerrarlo no es la respuesta adecuada a quien obró por un instinto de autoprotección. En esencia, se debe utilizar el hecho de la fuga para generar una oportunidad de resocialización.

Dentro de la idea del bien, en todas sus formas, está incluida la idea del mal, en todas sus formas. ¿Por qué así? Porque cualquiera que sea la forma en que sea posible que un mal se presente, la exclusión o extirpación de él produce un bien correspondiente; y del mismo modo, bajo la idea del mal, en todas sus formas, está incluida la idea del bien, en todas sus formas. Por consiguiente, el bien puede estar dividido y señalado como positivo y negativo. El bien positivo, es un bien que no consiste en la ausencia o extirpación del mal; el bien negativo es un bien que consiste en la exclusión o extirpación del mal. Siendo opuestos el bien y el mal, lo que se afirma de cada uno de ellos, puede ser, con un cambio adecuado en el texto, con igual veracidad y propiedad, afirmado del otro; y de igual modo con respecto al premio y al castigo.

(Bentham, 1965, p.180).

En suma, si resulta innecesario castigar a una persona por una conducta típica, cuya acción se debió a una situación extrema que atiende un instinto (la emoción violenta, por ejemplo); con mayor razón, resulta innecesario y contraproducente castigar a una persona que obedece a su instinto de búsqueda de la libertad para escapar sin violencia de los centros de menores (que son impropios para su propósito actual). El medio determina que es más útil mantener en libertad a un menor no violento que en un centro juvenil peruano. 


\section{3.- La búsqueda de la libertad, conducta humana inherente a la naturaleza humana}

Para Montesquieu, la humanidad se sitúa en un término medio entre la concepción de Hobbes, de que el hombre es malo por naturaleza y la de Rousseau, de que es bueno, pues depende de muchas causas extrañas que lo hacen que se comporte de diferentes maneras. Así Montesquieu adquiere una posición relativista, derivada de sus estudios, lo que le lleva a tener una concepción clara de las complejidades de la filosofía política que, según su pretensión, fuese aplicable a la mayor diversidad posible de circunstancias. De este modo, en la vinculación entre el ser humano y su medio ambiente la razón tiene que entender la forma de relacionarse con el clima, el suelo, la forma de gobierno, el comercio, la religión y las costumbres de las sociedades. Con estas concepciones se va constituyendo la obra por la que más se le reconoce: El Espíritu de las Leyes.

(Gutiérrez Pantoja, 1999, p.xxi.

Los instintos no son reprogramables, se encuentran en nuestra cadena genética, llevamos esta característica por la evolución humana, ha sido construida aprendida, por eso goza del mayor privilegio, el más alto es el de nuestros instintos, el más básico, sin ellos perdemos la etiqueta de seres humanos. Aunque quisiéramos este lugar está reservado y desde la primera existencia, la historia lo demuestra, frente a cualquier imposición que violenta a la libertad: la humanidad reacciona.

La cárcel es un gran desperdicio de talento, un desierto de tiempo que obliga a los internos a sacar a flote todas sus habilidades para la sobrevivencia y la búsqueda de supremacía. Por poner un ejemplo: el primer día que se anunció en televisión un producto comercial para eliminar verrugas por criogenia (a cincuenta grados bajo cero ocho segundos) recibí tres visitas que me preguntaban si eso era verdad. Les dije que suponía que sí y de inmediato razonaron: "podemos congelar cualquier cerradura o candado y romperlo como en las películas". Así debe ser.

(Maldonado Manzanilla, 2010, p.81).

Las personas defienden sus instintos, los superponen, exploran alternativas de salida, todo ello en segundos, es nuestra respuesta. Si la desesperación que sufrimos se produce en segundos, así también responden nuestros instintos; sin embargo, cuando esta respuesta es repelida, el tiempo de respuesta se extiende; nuestro contexto debe permitir que esta respuesta sea posible.

Hoy se castiga tal instinto, se vulnera la libertad garantizada cada vez que el Estado recaptura a los menores fugados con el propósito de castigarlos y causar diferentes contravenciones en su integridad física y psicológica. Cabe destacar que la motivación de este trabajo lleva su origen en los hechos que recogen las historias de los Operadores de recaptura, ya que ellos comentaron a los funcionarios de los Centros Juveniles de Diagnóstico y Rehabilitación que los lugares más habituales donde los menores fugados fueron recapturados son sus hogares familiares. 
Generalmente los menores infractores que logran fugarse no regresan a su pandilla, o a algún lugar donde desarrollaron sus vicios e infracciones; fugan y retornan a sus casas con sus familias.

De las entrevistas realizadas a diferentes servidores y funcionarios públicos de los Centros Juveniles de Diagnóstico y Rehabilitación de Lima, y del análisis posterior se demuestra que los menores que entran a un centro de reclusión están pensando en escapar, no importa el tiempo de la condena, si es corta o son varios años, es indiferente para ellos; lo único que buscan es salir, desde el primer momento. Por tanto, se estudia a la fuga reconociendo un dato de la realidad pues los encerrados están impulsados por sus deseos e instintos para evadir. Solo deben encontrar una oportunidad y en algunos casos gestar un plan de escape.

Finalmente, la necesidad por volver a la libertad es apremiante, no importa el conducto $\mathrm{u}$ objetos utilizados, la finalidad es necesaria. "Cuando dos libertades son contradictorias la que debe imponerse es la del mayor número; esto implica muy lógicamente que la tiranía ejercida por la colectividad estará justificada" (Grimal, 1998, p.68.

\section{4.- Una salida oportuna: Cortar el medio de contagio y facilitar la sanación}

En atención a la prevención y control de la actividad infractora, la Criminología muestra el fenómeno delictivo desarrollado por la teoría del Contacto diferencial y del Interaccionismo Simbólico.

La Criminología tiene también la misión de estudiar cuándo el recurso al Derecho penal (a la criminalización de conductas) y a sus instrumentos y arsenal teórico es la forma más adecuada para resolver determinados problemas. En este sentido, a la Criminología le corresponde, por tanto, la tarea de denunciar cuándo la función del Derecho penal es puramente "simbólica", sin mayor eficacia en la solución de los problemas o incluso con efectos contraproducentes o "criminógenos", evitando así su manipulación política o que se despierten en la población unas expectativas de solución que luego no pueden cumplirse en la realidad.

(Hassemer y Muñoz Conde, 2012, p.23).

Para entender que una salida oportuna puede tener un gran impacto en la población de jóvenes que se encuentran cumpliendo una medida de internamiento en un medio cerrado, es necesario desarrollar las posiciones que se crean a través de las medidas preventivas; ello evidenciará las oportunidades y las situaciones que hacen permisible utilizar este recurso penitenciario.

Existen tres clases de prevención: 
- Prevención primaria: Centrada en los factores de riesgo que en esta tesis se ha desarrollado en el apartado "Cuál es el origen del crimen". Un conjunto de formas de relación, situaciones y actitudes que pueden generar conductas que tienen relación con el mundo criminal “(...) pueden favorecer la aparición de otros problemas (alcoholismo, drogas, deserción escolar, aislamiento social, etc.), colocando a las niñas, niños y adolescentes en riesgo. La atención oportuna de las necesidades básicas (educación, salud, trabajo, etc.) es una de las principales acciones estratégicas de este nivel de prevención, conocida también como prevención social" (Consejo Nacional de Política Criminal, 2014, p.35). Por tanto, la atención en este aspecto es anterior al estigma criminal, evita que situaciones o factores de riesgo pueden convertirse en condiciones peligrosas y favorecedoras para la comisión de delitos/infracciones; centra la acción de ayuda en las familias, en los niños pequeños, evitar su estado de abandono o falta de educación. El camino del “desarrollo humano" está impregnado de enseñanzas dentro y fuera del hogar, el colegio y la iglesia cumplen un rol importante en este aspecto, es allí, en la etapa de desarrollo que se busca un mecanismo preventivo. Un joven sin intereses deportivos, académicos o altruistas se sentirá impulsado por alcanzar placeres momentáneos sin reflexionar en las consecuencias de estas acciones: una enfermedad venérea, adicciones, o inclusive son convertidos en herramientas por otros sujetos que abusan de ellos y los utilizan para lograr sus fines ilícitos (sicariato, tráfico ilícito de drogas, posesión de armas, etc.) En consecuencia, mantener un ambiente primario beneficioso y de interés para el menor es esencial para evitar que sea captado por malos hábitos y contextos donde desarrollar perfiles criminales es más fácil y parte de la "normalidad". La prevención primaria disminuye el ratio criminal ya que detiene la generación de oportunidad criminal, es un esfuerzo necesario y previo a la comisión delictiva (Barkan, 2012).

- Prevención secundaria: Este aspecto desarrolla el ámbito en un entorno práctico que necesita acción inmediata que pueda contrarrestar el problema del sujeto (es decir, el adolescente). "Estos grupos pueden estar focalizados a nivel de comunidad, familias o individuos que poseen ciertas características que los catalogan como de alto riesgo (familias disfuncionales, consumo de droga, alcohol, violencia de género, deserción escolar, pandillaje, etc.)" (Consejo Nacional de Política Criminal, 2014, p.35). Es decir, 
si una persona ya se encuentra dentro de un factor de riesgo, se deben brindar mecanismos de salida para cambiar de ambiente y reducir el impacto de estos factores. En este escenario, una relación laboral exitosa puede alejar a una persona de un medio peligroso, crea responsabilidades y se obtiene satisfacciones múltiples, no solo de índole patrimonial sino también en el aspecto moral (Barkan, 2012).

- Prevención terciaria: En un contexto donde la primera y segunda alternativa no fueron aplicadas de manera exitosa, resulta necesario evitar que las personas que ya tuvieron problemas con la ley penal mantengan un contacto con factores de riesgo y con los círculos criminales. Por tanto, se busca un buen método resocializador, suma de oportunidades y evitar la reincidencia (Barkan, 2012).

\section{Tabla 5.1}

Tipos de prevención. Una guía de políticas y acciones para cada tipo de prevención

\begin{tabular}{|c|c|c|c|}
\hline PREVENCIÓN & PRIMARIA & SECUNDARIA & TERCIARIA \\
\hline ORIENTADO HACIA & \begin{tabular}{|c|} 
Establecer situaciones que \\
reducen oportunidades en la \\
aparición de problemas
\end{tabular} & $\begin{array}{c}\text { Estrategias para evitar que los } \\
\text { problemas se consoliden }\end{array}$ & $\begin{array}{l}\text { Disminuir daños y evitar } \\
\text { repeticiones }\end{array}$ \\
\hline ADOLESCENTE & \begin{tabular}{|c|} 
Prevención General. Politica \\
Social y Sanitaria. Politica \\
Laboral y urbanistica. \\
Protección de menores de \\
edad. Adopción de menores \\
de edad.
\end{tabular} & $\begin{array}{c}\text { Prevención individual. } \\
\text { Trabajo social. Terapia para } \\
\text { drogadictos }\end{array}$ & $\begin{array}{c}\text { Politica social de } \\
\text { Resocialización / Restauración } \\
\text { rehabilitación }\end{array}$ \\
\hline VÍCTIMA & Estrategias para evitar riesgos & \begin{tabular}{|c|} 
Comportamiento en el \\
encuentro con el delincuente. \\
Autodefensa
\end{tabular} & Terapia de crisis. Restitución \\
\hline COMUNIDAD & $\begin{array}{c}\text { Control informal. Vigilancia } \\
\text { Vecinal }\end{array}$ & Ayuda en situación de crisis & $\begin{array}{c}\text { Colaboración ciudadana para } \\
\text { esclarecer los delitos. Apoyo a } \\
\text { vecinos que han sufrido un } \\
\text { delito }\end{array}$ \\
\hline MEDIO AMBIENTE & $\begin{array}{c}\text { "Espacio defendible" } \\
\text { Arquitectura Dinero } \\
\text { electrónico. Coches antirrobo } \\
\text { de serie }\end{array}$ & $\begin{array}{l}\text { Sistemas de protección: } \\
\text { Cerraduras, alarmas, etc. }\end{array}$ & $\begin{array}{l}\text { Reparación. Evitar deterioro } \\
\text { en edificios o zonas públicas. }\end{array}$ \\
\hline
\end{tabular}

Fuente: Garrido, V., Stangeland, P. y Redondo, S. En CONSEJO NACIONAL DE POLÍTICA CRIMINAL. (2014). Plan Nacional De Prevención Y Tratamiento Del Adolescente En Conflicto Con La Ley Penal 2013 2018. Lima: Grupo Raso E.I.R.L. Pág. 35.

Por tanto, en esta tesis se aborda la tercera forma de prevención (Prevención Terciaria), para disminuir el aprendizaje de conductas más nocivas y alejar de ellos situaciones adversas y de mayor o duradero peligro. 
En todo caso, la Política Criminal del Estado de Derecho no tiene siempre que recurrir al Derecho penal para combatir eficazmente la criminalidad. Sobre todo en el aspecto preventivo, tiene que ser consciente de que muchas veces hay otras formas de prevenir la delincuencia, como mejorar el nivel cultural, educativo y económico, hacer una mejor política de redistribución de rentas, ayudar a la promoción e integración social de los más débiles con medidas de carácter social, posibilitar la reinserción social de los que ya han sido condenados, mejorar el sistema penitenciario, etc. Siempre se ha dicho que la mejor Política criminal es una buena Política social (económica, educativa, etc.). (Hassemer y Muñoz Conde, 2012, p.27).

El Perú no cuenta con un programa apto para resocializar eficientemente, los programas son diseñados para un tiempo inferior al de las condenas promedio. Es decir, el programa en la práctica tiene una duración de un año y medio a dos años, sin embargo, las medidas correctivas se han fijado en 3 años. "En cuanto a programas de reeducación, se presenta una inconsistencia entre el tiempo de la sanción y los programas de tratamiento. Primero, porque los programas no han sido diseñados para albergar adolescentes con sanciones menores a 6 meses; segundo, porque el tiempo máximo de internamiento debería ser de 3 años y existen sanciones de hasta 6 años; y, tercero, porque se ha demostrado que a partir del segundo año de internamiento inicia una involución en el tratamiento. En consecuencia, las sanciones parecen manejar una temporalidad distinta a la del tratamiento" (Consejo Nacional de Política Criminal, 2014, p.93).

Existen cuatro Programas, cada uno implica aspectos de seguridad, comodidad y beneficios que se obtienen de manera progresiva, según el comportamiento del adolescente. Sin embargo, no es fácil llegar a este programa, además aquellos jóvenes que mantienen buena conducta, también forman parte de un determinado grupo (que los protege y solicita fidelidad o permanencia); es por ello que los jóvenes no quieren ser trasladados a un programa diferente; pese a que el mejor programa brinda condiciones de internamiento adecuado. Asimismo, el cupo para este programa es muy limitado, se debe tener en cuenta que existen en promedio 900 jóvenes internados en el CJDR de Lima (Maranguita), y que el espacio del cuarto programa está limitado solo para 20 personas, en promedio. En la fecha de la visita realizada por el autor de la tesis, en el verano del 2017, de los 900 internos solo 14 se encontraban en el cuarto programa.

Adicional a ello, los programas resultan repetitivos para un joven que tiene 2, 3 o 4 años de medida socioeducativa de internamiento; en aquel contexto también se produce un periodo de involución en el tratamiento. El programa sigue el curso regular y los métodos, enseñanzas se limitan a la repetición de contenidos, pese al logro en el objetivo, el adolescente que aprendió a tejer, deberá volver a realizar el mismo taller desde el inicio, con los mismos educadores y en las mismas condiciones. Si el joven terminó el curso de álgebra, deberá repetirlo, pese a que terminó 
el curso con éxito; ello como consecuencia que aún quedan 2 o 3 años más de medida de internamiento en medio cerrado, sujetos a una convivencia nociva.

Aquellos menores que cumplieron con las disposiciones, se esforzaron por lograr buenas condiciones, encuentran una administración penitenciaria perjudicial y no preparada para mejorar su realidad. Al no encontrar una alternativa más idónea que mantenerlos encerrados y repitiendo una y otra vez lo que ya hicieron por dos años. Los adolescentes mantienen medidas mayores a los 3 años, seguirán en el mismo ambiente, repitiendo los conceptos y talleres que desempeñaron de manera exitosa los años pasados. Ello desincentiva y genera ansiedad y pérdida de control que los llevará a ser más rebeldes y renegados con la sociedad. El sistema los arrastra a una situación llena de desaciertos que terminan en un retroceso grave y perjudicial; merma el desarrollo intelectual, físico y afectivo de la persona humana.

Finalmente, un elemento posterior a esta muestra de inefectividad del sistema se halla en el Programa de Intervención Intensiva, lugar de castigo severo y aislamiento. “(...), no solo la ausencia de valores en el adolescente genera para el mismo un factor de riesgo, sino también la falta de empatía de la sociedad para con el adolescente en conflicto con la ley penal, lo que se traduce en una ausencia de corresponsabilidad que provoca exclusión o marginación social, haciendo difícil la Resocialización/Restauración social." (Consejo Nacional de Política Criminal, 2014, p.39).

\section{5.- ¿Promueve la ley penal la fuga de los internos?}

Meter a alguien en la prisión, mantenerlo en la prisión, privarle de alimento, de calor, impedirle salir, hacer el amor..., etcétera, ahí tenemos la manifestación de poder más delirante que uno pueda imaginar. El otro día hablaba con una mujer que había estado en la prisión y me decía: "Y a mis cuarenta años me castigaron un día en la prisión poniéndome pan seco". Lo que sorprende en esta historia no es sólo la puerilidad del ejercicio del poder, sino también el cinismo con el que se ejerce ese poder, de la forma más arcaica, más pueril, más infantil. Reducir a alguien a pan y agua es lo que nos enseñaron cuando éramos unos chavales. La prisión es el único lugar donde el poder puede manifestarse en su desnudez, en sus dimensiones más excesivas, y justificarse como poder moral. "Tengo razón en castigar, puesto que tú sabes que está mal robar, matar..." Esto es lo fascinante de las prisiones; por una vez el poder no se oculta, no se enmascara, se muestra como feroz tiranía en los más ínfimos detalles, cínicamente, y al mismo tiempo es puro, está enteramente "justificado", puesto que puede formularse enteramente en el interior de una moral que enmarca su ejercicio: su bruta tiranía aparece entonces como dominación serena del bien sobre el Mal, del orden sobre el desorden.

(Foucault, 2015, pp.35-36). 
Recordando que la fuga de un Centro Juvenil de Diagnóstico y Rehabilitación no está tipificada como delito o infracción penal. Este capítulo desarrolla un cuestionamiento en la aplicación del internamiento a partir de los principios constitucionales, teniendo en cuenta la intención punitiva exorbitante que ejerce la administración. Se advierte una contradicción entre lo que propone la ley penal y lo que ejecuta la administración de los Centros Juveniles; asimismo, resulta conocido que la ley penal no castiga la acción de escape o fuga. Es por ello pertinente preguntar si: la ley penal promueve o alienta la fuga.

Para responder aquella pregunta se debe analizar el concepto material de delito, y por ello cabe la identificación del daño o riesgo en el detrimento de un bien jurídico protegido. Para identificar que cierta conducta es dañosa o riesgosa se debe primero identificar aquellos riesgos tolerables y los prohibidos; es posible distinguirlos por un análisis costo/beneficio donde la tolerancia de algunos riesgos depende del beneficio derivado de la conducta riesgosa. El beneficio debe exceder al daño para que ciertas conductas sean toleradas por la sociedad. Por ejemplo, es necesario tolerar la circulación de vehículos automotores pese a que suponen riesgos para bienes jurídicos como la vida, integridad física y salud; en cambio no será posible el libre porte o tenencia de armas de fuego, ya que la sociedad en la que vivimos entiende que el riesgo y daño son mayores a los beneficios, toda vez que con un arma de fuego se puede terminar con la vida, lesionar gravemente, mutilar o paralizar de manera permanente a una persona.

Después de este análisis, entre el costo y beneficio de una actividad es posible determinar la tolerancia del Estado, que permitirá la convivencia de ciertos riesgos y prohibirá otros que resulten más dañinos y casi nada beneficiosos. En ese sentido, el Estado encierra a personas que causan daños a la sociedad, porque cometieron riesgos prohibidos y para evitar daños futuros intenta mitigar el crimen de esa manera que no necesariamente ofrece resultados positivos.

En esencia, se debería encerrar solo a personas que dañen bienes jurídicos de primer orden, ya que resulta necesario e indispensable enseñar que el bien que dañaron es de trascendente importancia. No obstante, el castigo es más que severo para aquellos que vulneraron algún bien jurídico menor y generalmente recuperable, como el dinero o un bien mueble de relativamente fácil adquisición (sin violencia). La naturaleza del bien jurídico, si es, o no recuperable, forma parte del elemento valorativo que toda norma penal mantiene: Factor prohibitivo (conducta no tolerada) y factor valorativo (referente al daño). Para que se configure un delito no es necesario que ambos factores se encuentren en alguna conducta, será necesaria la sola vulneración de la 
prohibición para que dicha conducta sea entendida como merecedora de un castigo; el daño solo medirá la intensidad de la medida socioeducativa impuesta.

Cuando uno se pregunta por qué se amenaza con una pena el comportamiento de riesgo para el bien jurídico, salta a la vista que el juicio de valor que recae sobre él indica que es un comportamiento que merece pena. Luego como solo es legítimo prohibir aquello que el sujeto libremente se ha comprometido a evitar y que puede ser razonablemente evitado, el delito solo puede ser atribuido a quien se le exige evitarlo.

(Meini, 2014, p.49).

En consecuencia y después de este análisis preguntamos ¿El menor no violento daña algún determinado bien jurídico protegido con la acción no violenta de fuga? Y por tanto ¿Existe en el ordenamiento legal, la razonabilidad necesaria para evitar una conducta de este tipo?

Estimo que no es posible hallar en la acción fuga el daño de un bien jurídico relevante determinado, toda vez que no hemos centrado en una fuga sin violencia y amparada en el instinto de recuperación de la libertad. Para conocer la razonabilidad necesaria, se deberá contraponer la naturaleza humana y el actuar de evasión.

Asimismo, resulta necesario referir que en democracia se ha aceptado que el Derecho Penal es fragmentario y subsidiario en su aplicación, es decir, de ultima ratio.

El ideal de evasión no violenta que contempla esta tesis está basada en dos casos reales que fueron comentados por dos funcionarios de la administración de los Centros Juveniles de Diagnóstico y Rehabilitación conocidos como Santa Margarita y Maranguita. En la primera, una menor de edad proveniente de la selva del Perú, trepó de manera muy ágil un tubo colocado junto a la pared del Centro Juvenil, de esa manera logró sobrepasar el muro que la separaba de la calle y así logró la libertad ${ }^{21}$. En el segundo, la lluvia intensa de la selva del Perú ocasionó que uno de los postes del arco de fútbol, en el campo de deporte donde jugaban los menores internos, se deslizó en el lodo; de esa manera, los menores que hacían deporte al darse cuenta de la facilidad en que se movía la estructura, sacaron de la base el arco y lo colocaron contra una pared, treparon y obtuvieron libertad 22 .

En ambos casos primó el instinto por recuperar la libertad; no amenazaron a ninguna persona, no existió un acto de corrupción, no hubo violencia, tampoco se emplearon armas; la

${ }^{21}$ Capítulo V, literal c) del presente trabajo.

${ }^{22}$ Capítulo V, literal d) del presente trabajo. 
situación generó una oportunidad, actuó el instinto y se concretó el escape ¿En ambos ejemplos, es posible que el Derecho penal identifique daños sobre bienes jurídicos relevantes?

Un enfoque garantista supone que existe un comportamiento que justifica la acción escapar: cualquier persona en estado de encierro buscará y aprovechará una situación que permita obtener su libertad. Después de todo, la libertad es un bien jurídico esencial y muy relevante para la humanidad y el ordenamiento nacional, junto con la vida, la libertad es fundamental e inherente a los seres racionales.

En 1810 Feuerbach acuña los términos; Nulla poena sine lege, nulla poena sine crimine, nullum crimen sine poena legalis (no hay pena sin ley, no hay pena sin crimen, a todo hecho criminal le corresponde una pena legal). La retención del mal fundamenta la acción de la ley y viabiliza la posibilidad jurídica del castigo; ello supone un daño a un determinado bien jurídico protegido. Una vez más ¿Cuál es el bien jurídico protegido en una fuga sin violencia, amparada por el instinto de búsqueda de la libertad?

Como ha expuesto ROXIN un Estado de Derecho debe proteger al individuo no sólo mediante el Derecho penal, sino también del Derecho Penal. El ordenamiento jurídico no sólo ha de disponer de métodos y medios adecuados para la prevención del delito, sino que también ha de imponer límites al empleo de la potestad punitiva, para que el ciudadano no quede desprotegido y a merced de una intervención arbitraria o excesiva del "Estado Leviatán.

(Roxin, 1997, p.13).

Esta protección encuentra su relevancia, límites y origen en los principios de la actividad punitiva, conceptos también desarrollados y amparados por el Derecho Constitucional “(...) son los límites materiales entre los que se encuentran, el principio de necesidad de la intervención, el principio de la dignidad de la persona, o el principio de protección de bienes jurídicos" (De Vicente Martinez, 2004, p.13).

Sin duda, el fundamento de mayor relevancia y utilidad para el presente trabajo es desarrollado por el principio de legalidad, toda vez que cumple una función limitadora; es garante y freno de la acción de los dos poderes restantes -Ejecutivo y Judicial-, “(...), sino que incluye asimismo una función de garantía de la libertad de los ciudadanos al condicionar taxativamente el catálogo de delitos y penas a la decisión de una instancia democráticamente constituida -el poder legislativo- que, como representante de la soberanía judicial, actúe como freno ante los posibles abusos de los poderes ejecutivo y judicial” (De Vicente Martinez, 2004, p.14). 
"Franz VON LISZT, quien veía en el principio de legalidad un serio obstáculo para la realización de su utopía penal de abolición del Código, denominó al principio de legalidad con una expresión de éxito en su tiempo: La Carta Magna del delincuente" (1970, pp.14-15). Asimismo, De Vicente Martinez, atribuye el origen de este principio en el mundo de la filosofía, pues encuentra los ideales del Contrato Social de Rousseau y la división de poderes que desarrolla la obra El espíritu de las leyes de Montesquieu. No deja de lado al joven Beccaria para explicar que sólo la ley es la que determina una pena para los diversos delitos, y la creación de estas leyes está a cargo solo de un ente: el legislador; ellos representan toda la sociedad, y su ánimo y finalidad están nuevamente en los ideales del contrato social ("Beccaria: sólo las leyes pueden decretar las penas de los delitos, y esta autoridad debe residir únicamente en el legislador, que representa toda la sociedad unida por el contrato social (...)" (De Vicente Martinez, 2004, pp.17-18). Este principio alcanza un rango legal en el Código penal bávaro de 1813 (Feuerbach), y es el triunfo de la Revolución Francesa quien dota al principio de importancia fundamental para el Derecho penal liberal (De Vicente Martinez, 2004, p.20).

Del mismo modo, este fundamento limitador tiene una múltiple función prohibitiva, que el Poder Ejecutivo (mediante la Administración de los Centros Juveniles) parece olvidar, y que además vulnera con su actividad aquellas prerrogativas dadas exclusivamente al Poder Legislativo "El significado esencial del principio de legalidad se concreta además en estas cuatro prohibiciones: Prohibición de retroactividad de las normas que fundamentan o agravan la pena, prohibición de regulación de la materia penal por normas dimanantes del Ejecutivo, prohibición de la analogía y, en general, de la creación judicial del Derecho, y prohibición de regulación de la materia penal por normas consuetudinarias" (De Vicente Martinez, 2004, p.28).

Ahora bien, la determinación de la norma penal incluye la prohibición de una conducta, es decir, imposibilidad de acción. El cuerpo legal contempla para ciertos actos, un listado con agravantes (de misma finalidad prohibitiva). La ley penal impone para la comisión de una infracción penal un castigo definido como una medida socio-educativa; no obstante, no determina como un delito, o infracción agravante, la fuga de algún Centro Juvenil de Diagnóstico y Rehabilitación. Sin embargo, como se ha dicho, el menor que escapa, es perseguido, atrapado, golpeado, nuevamente encerrado y sus condiciones de encierro se ven severamente afectadas. En ese sentido, el menor prófugo, no volverá a su "Programa" anterior, sino que es encerrado en el Programa de Intervención Intensiva (PII). 
Por tanto, el menor que logra escapar (con o sin violencia) pasará, por lo menos un mes, en un completo aislamiento, prohibido de visitas, con una cama de cemento, a veces sin colchón, sin ventanas, con una pequeña rejilla en la parte derecha superior de una de las paredes de aproximadamente 30 centímetros de largo y 10 de ancho, sin posibilidad de salida ni educación; para el caso del Centro Juvenil para mujeres, solo recibirán la visita de un educador por media hora de las 23 y media restantes.

Es menester reconocer, el cumplimiento del principio de Legalidad, presupone el respeto y promoción de la seguridad jurídica. Toda vez que prohíbe al Poder Ejecutivo y al Poder Judicial la creación de delitos, infracciones penales y penas (o medidas socioeducativas) mediante sus actos (De Vicente Martinez, 2004, p.28). Aquel es el supuesto estudiado por la presente tesis: el orden Ejecutivo, mediante su cuerpo administrativo, castiga la fuga cuando el Legislador no ha prohibido ni ha castigado dicha conducta.

Por un lado, la concepción del derecho como razón al servicio de la convivencia libre y pacífica de las personas. Por otro, que el derecho penal protege la libertad que las personas necesitamos para desarrollar nuestra personalidad en sociedad, y lo hace restringiendo la libertad de actuación cuando su ejercicio menoscaba la legítima libertad de actuación de un tercero. A nadie, y menos al Estado, le asiste la prerrogativa de limitar la libertad de actuación de un ciudadano por otra razón. Quien la hace actúa ilegítimamente.

(Meini, 2014, p.21).

Este principio, en la esfera formal y material, no admite la intromisión del Poder Ejecutivo en el entorno limitativo de la libertad. La acción fuga no está tipificada como delito, no tiene una conducta descrita en el ordenamiento penal y mucho menos establece una pena privativa de libertad para aquel que la cometa.

La doctrina penal alemana distingue en el principio de legalidad, por un lado, un aspecto formal, del que se derivarían las exigencias de prohibición del derecho consuetudinario, prohibición de analogía y prohibición de retroactividad de las leyes penales no favorables, y por otro lado, un aspecto material, del que se extraerían las exigencias de concreción y determinación en las descripciones legales de las conductas delictivas y sus penas correspondientes.

(De Vicente Martinez, 2004, p.35).

Aquel adolescente no violento que escapa de un Centro Juvenil, será sometido a un castigo indebido, ya que una vez capturado, y después de recibir un adiestramiento violento será aislado a un lugar preciso para uso de castigo: el Programa de Intervención Intensiva. "Para la doctrina española, el principio de legalidad, como expresión de su plural fundamento, se plasma en más 
exigencias o prohibiciones, en concreto en las siguientes: (...) Quinta: Exclusión de la sanción penal y administrativa para un mismo hecho (...)" (De Vicente Martinez, 2004, p.36). Asimismo, y pese a la costumbre desarrollada por la vía administrativa que sanciona la acción de fuga, existe un rechazo de la Ley penal sobre la costumbre como fuente del Derecho penal. "Frente a otras ramas del Ordenamiento Jurídico donde las fuentes del Derecho son, a tenor de los dispuesto en el artículo 1.1 del código civil, "la ley, la costumbre y los principios generales del Derecho", la ley penal debe ser "escrita"." (De Vicente Martinez, 2004, p.37).

En suma, en el presente apartado se el significado de la impunidad en la acción fuga. El propósito del vacío legal no alienta a los privados de libertad a huir del encierro impuesto, tampoco deja una puerta abierta para que el riesgo se incremente y se pierda legitimidad jurídica. Más bien, existe un acuerdo en la sociedad para cuidar la libertad, se entiende que este bien de primer orden es en principio incontenible y tolera ese riesgo ya que prohibir la evasión se afectaría directamente la naturaleza humana; asimismo, la independencia/respeto de Poderes nutrirá la institucionalidad democrática, ello logra la armonía y eficiencia en un Estado de Derecho. "La prohibición de analogía como medio de creación y aplicación de preceptos penales así como de agravación de las penas y medidas ya existentes es un corolario del principio de legalidad: Todo lo que no está prohibido está permitido" (De Vicente Martinez, 2004, p.58).

“Como ha expuesto VIVES ANTÓN, el principio de legalidad es una norma objetiva de la Constitución, que tasa las fuentes del Derecho penal reduciéndolas a la ley -“praevia, scripta et scricta"- y, a la vez, un derecho fundamental o garantía del ciudadano que no puede ser castigado sino en virtud de una ley de esas características” (De Vicente Martinez, 2004, p.58).

Es posible resumir y concluir este subtítulo con lo determinado por Meini:

(...) la intervención penal se legitima si y solo si el comportamiento prohibido es una intromisión no autorizada en la esfera de libertad jurídicamente garantizada de un tercero. Sin este requisito de legitimación, aun cuando el comportamiento en cuestión agite los más profundos sentimientos morales o religiosos, el derecho penal no está autorizado a intervenir. Esta es la razón por la cual se sanciona el homicidio, pero no el suicidio; o el hurto y no la donación. Y es la razón también por la cual las leyes penales que reprimen conductas que no vulneran la libertad de terceras personas, sino que la respetan y realizan, como la eutanasia (artículo 112 del CP) o la ayuda al suicidio (artículo 113 del CP), son propias de un Estado paternalista que se arroga la facultad de decidir por sus ciudadanos y, por tanto, resultan ilegítimas en un Estado de derecho.

(Meini, 2014, pp.26-27). 
Finalmente, el menor que escapa ya vulneró al ordenamiento legal, existía una ley quebrantada y se ejecutó el castigo. No obstante, la acción de fuga no es computada como un delito ¿Por qué entonces existe una apariencia de castigo? ¿Por qué la ley administrativa emplea violencia física y psicológica cuando persigue al menor que escapó?

La pena ejerce una coacción psicológica en los ciudadanos que les hace abstenerse de la comisión de delitos, pero para que pueda desempeñar esta función es necesario que se describan previamente en la ley las conductas prohibidas y las penas con que se conminan esas conductas. Sin esa previa descripción legislativa, el potencial delincuente, no podría saber, si su conducta estaba previamente prohibida y castigada y, por consiguiente, no significaría la pena una coacción psicológica para nadie.

(De Vicente Martinez, 2004, p.19).

\section{6.- Enfoques criminológicos y económicos}

Bentham señala que: "Toda cuestión política o moral debe presentarse desde el punto de vista de los hechos; y de esta manera la humanidad está dirigida por el único camino verdadero de la investigación, que puede proporcionar instrucción o esperanza de una argumentación racional: el camino de la experimentación y de la observación" (Bentham, 1965, p.173). El Estado ha desarrollado prácticas y mecanismos para reducir los índices de criminalidad. Por tanto, observaremos las consecuencias que arrojan estas prácticas, todo ello para finalmente detectar si el sistema generó resultados contraproducentes o eficientes.

En ese sentido, el derecho por sí solo se extiende en el mundo de las ideas y abstracciones, una norma se crea y aplica por determinación del legislador; responde a un análisis de necesidad y finalmente está sujeta a una votación parlamentaria. La creación de leyes es un acto que necesita deliberación, las personas que elegimos para representarnos en el poder legislativo proponen los nuevos lineamientos, discuten su necesidad, urgencia y características, y finalmente, emiten una decisión que se adapta e impone a la sociedad; esta es una de las principales fuentes generadoras del Derecho.

No obstante, el nacimiento de derechos y obligaciones -a través de leyes deliberadas- sin la consideración de los estudios de la economía suponen un riesgo, y la probabilidad de inaplicación, desuso y por ende derogación. Se debe tener en cuenta que la abstracción (que implica la ley), no responde a una lógica cartesiana; es decir, no soporta el análisis de la lógica proposicional donde se puede determinar que un enunciado es verdadero o falso. Una ley no es falsa ni verdadera, es el resultado de un ejercicio (praxiológico) que busca la obtención de 
beneficios; sin embargo, el análisis de los costos que conllevan tal utilidad debe ser solventemente considerado.

En aquel contexto resulta menester aplicar un análisis económico al derecho, ya que éste determinará el éxito de la norma: utilidad, costos, riesgos, beneficios y usos. "La legislación penal, por ejemplo, no sólo significa dolor para quien sufre la pena, sino también costos (bajo la forma de impuestos) para toda la comunidad por el establecimiento y la realización de la punición. Ella sólo se justificaría si los beneficios estimados superen estos costos y el dolor impuesto al condenado" (Araujo, 2003, p.276).

En consecuencia, se aconseja utilizar criterios económicos que analicen la realidad para observar el impacto que tienen las leyes en el "mundo real", ello brindará viabilidad a las ideas determinadas por el legislador. En aquel camino, esta tesis utiliza el concepto que desarrolla Pareto para determinar qué es eficiente y bajo qué parámetros se pueden desarrollar buenas prácticas que encuentren el beneficio en las partes integrantes. Pareto explica que una situación será eficiente si las partes que intervienen en el esquema interesado incrementan sus recursos o beneficios, el beneficio no se puede obtener a costa del otro, debe ser proporcional para ambos. Si A sube entonces B también se incrementa en igual medida. Si esto ocurre, la operación será eficiente.

Por tanto, el siguiente análisis tiene el propósito de determinar los aciertos o descuidos en la administración del derecho penal; este ámbito incluye indefectiblemente a la criminología, derecho penal, derecho procesal penal, derecho penitenciario, entre otros. Todas coadyuvan para obtener los mismos fines: reducir el índice criminal, educar, disuadir y resocializar.

En un esquema/universo penitenciario, A será la nación, (representada por cada persona que conforma nuestra sociedad). Por tanto, el buen resultado para A será controlar los niveles de criminalidad, tener criminales menores, con bajos niveles de peligrosidad y que no ocasionen graves daños a la sociedad. Ello implicará que B (grupo de criminales) se encuentre en un estado de bienestar: mejoría en los tratamientos de rehabilitación y resocialización, calidad en infraestructura donde son albergados por todo el tiempo de castigo, programas efectivos que ayuden a salir de la condición criminal, control de sus problemas adictivos para evitar que se sumerjan en momentos de crisis. Es decir, si las herramientas son adecuadas para los grupos (A y B), ambos incrementan sus beneficios y condiciones. 
Es claro que este universo no puede obtenerse en el Perú debido a las condiciones que hoy presenta. Existe un desbalance que esta tesis pretende demostrar; todo ello con la finalidad de acortar la distancia y encontrar el balance en pro a la eficiencia.

En ese sentido, no será eficiente la relación que cubra las expectativas de un solo grupo. La realidad nos indica que A obtiene lo que quiere, y sin reflexionar acerca de las consecuencias logra alejar al mal de su esfera más cercana. Un modo práctico de eliminar el problema es encerrarlo en el rincón más lejano de la ciudad. Al hacer esto, las víctimas y el resto de la sociedad cree estar más segura y protegida; no obstante, los efectos de una política hacinadora acarrean una futura presencia criminal aguda y más violenta. El grupo B en contraste, reduce sus expectativas de mejora, son albergados en ambientes muy nocivos donde ellos también son víctimas de otros criminales más peligrosos; asimismo las condenas exageradas acarren la pérdida de oportunidades y de juventud, y con ella también se extravían las esperanzas de retornar a una sociedad ordenada, justa y fructífera.

Es decir, el grupo A cree que mejora, y disfraza al concepto de eficiencia de manera simultánea; en aquel momento el grupo B ingresa en las peores condiciones existentes. Para el Perú en apariencia y en realidad, el concepto de eficiencia que administra el problema criminal no existe. El ideal nos enseña un camino donde tanto A como B puedan obtener bienestar, este trabajo ayuda a observar aquellos puntos que permiten blindar de igualdad de condiciones a aquellos procesos impregnados de improvisación. Recordemos que el uso de la fuerza y la implementación de penas privativas de libertad o de medidas socio educativas de internamiento en medio cerrado conllevan la naturaleza de uso exclusivo y en última instancia (ultima ratio).

Por tanto, resulta necesario evidenciar cómo funciona nuestro sistema penitenciario, juntar los objetivos con estrategias; todo ello con el ánimo de no determinar resultados contraproducentes. Esta tesis tiene el ánimo de contrarrestar los errores de la administración criminal, busca a toda costa la formación de mejores y despiadados criminales. Por ello sugerimos brindar una oportunidad a aquellos menores que puedan escapar de estos medios nocivos. Esta "salida" mitiga, en alguna medida, el modelo obsoleto y costoso que el país utiliza para combatir el crimen. "Acciones públicas y privadas que intentan reducir el número y la incidencia criminal: se emplean guardias, porteros y contadores, se instalan cerraduras y alarmas, se extiende la cobertura del seguro, se evitan parques y colonias, se usan taxis en lugar de caminar o del metro, etc." (Becker, 2000, p.441). 
En consecuencia, el Análisis Económico del Derecho que junta la teoría legal y la contrasta con la realidad; el derecho por sí solo funciona de manera perfecta en el mundo de las ideas, es un conjunto de abstracciones que buscan reparar situaciones, limitar conductas, disuadir y educar. No obstante, la economía limitará la función de la ley, la adaptará a la realidad generando un resultado óptimo. En adición, el legislador considera que si la aplicación de la ley no le "costará mucho al Estado" habrá soportado el "análisis costo/beneficio" (que está obligado a hacer). El derecho es también esa cobertura humana que necesita la economía para poder aplicarse sin ocasionar daños o desproporciones.

Es menester señalar con un ejemplo por qué es necesario emplear a ambas ciencias en las tareas legislativas, ya que solo ello evidencia la necesidad de "ayuda" de ambas ciencias para la solución de problemas o métodos de desarrollo. Así Freakonomics, un libro con crítica económica muy leído a escala mundial, desarrolla varios aspectos de la cotidianidad y del mercado, pero también analiza el mundo criminal y de manera más precisa utiliza la pena de muerte para llenarla de valores estadísticos. El aporte más sorprendente fue desarrollado cuando establecía un análisis de probabilidad, donde era justificable acabar con la vida de una persona homicida, ya que, en promedio, una persona con esos rasgos asesinaba a 8 víctimas. Además, se decía que era muy favorable deshacerse del mal elemento ya que se salvarían -en promedio- 7 vidas humanas. Un análisis de este tipo, libre de conceptos y principios establecidos por el derecho generarían la destrucción de muchos seres humanos. La aplicación de la pena de muerte desnaturaliza a la humanidad, trae consigo problemas más graves y aún más costosos. "El castigo es una pérdida neta para la sociedad" (Levit, Dubner, 2009, p.147). El esquema evidencia que la escala de control interno debe ser de, más o menos, en medida de los progresos en la resocialización.

La economía también representa una oportunidad para incrementar los beneficios en las medidas o políticas adoptadas. En una política criminal que brinde resultados eficientes, es decir reduzca el número de criminales, la economía logrará mejores resultados ya que sugiere que la oportunidad que representa cada individuo se debe desarrollar y explotar; jamás limitar. Esto, coadyuva al fin resocializador y establece una disciplina sana y constante ocasionada por el trabajo bien remunerado.

Los medios más poderosos para aumentar la riqueza nacional son aquellos que mantiene la seguridad de las propiedades, y que favorecen, paulatinamente, su igualdad. Tales son los objetivos de las leyes civiles y penales. Las medidas que tiendan a incrementar la riqueza nacional por otros 
medios que no sean la seguridad y la igualdad (si los hubiese), pueden ser consideradas como pertenecientes a la clase de las leyes económicas" (Bentham, 1965, p.172).

En adición, se comentará sobre la necesidad de implementar medidas socioeducativas de internamiento como método disuasivo de conductas, el análisis económico del derecho nos ayudará a determinar el beneficio en su aplicación. "Si la importancia conjunta de estos cinco factores es lo suficientemente elevada, es decir, si la probabilidad de fracasar y al detener actos indeseables, junto con el daño esperado que resultaría de éstos, es suficientemente elevada, entonces puede ser deseable recurrir a las sanciones no monetarias a pesar de los altos costos sociales que acompañan su uso" (Shavell, 2000. p.441). Además, se demostrará que utilizar los escasos recursos disponibles en las consecuencias del crimen conlleva a una pérdida constante y profunda “(...) algunos castigos, como el encarcelamiento, son necesariamente no necesarios y representan un costo para la sociedad y para los infractores; el grado de incertidumbre es una variable de decisión que afecta tanto al ingreso como a las funciones de costo, etc.” (Becker, 2000, p.420).

Recordemos que toda sentencia de privación de la libertad conlleva la responsabilidad del Estado de proporcionar una serie de derechos que las personas en libertad se procuran por sí mismas, las cuales contemplan la alimentación y la salud. De hecho, cuanto más se restringen los derechos de las personas privadas de libertad, mayores son las obligaciones del Estado de asegurarles protección y acceso a servicios, incluida la atención médica. En otras palabras, los derechos llamados programáticos se transforman en absolutos e inalienables, es decir, en obligaciones del Estado con respecto a quienes están en prisión.

(Comisión Nacional de Derechos Humanos, 1995, p.52).

Resulta menester señalar que las personas son guiadas por todo aquello que represente un beneficio, y su decisión estará basada en un análisis interno entre los costos y beneficios que son parte de su escenario cotidiano. Aquello determinado por la ley que conlleve a la felicidad (beneficio) será observado, acatado y practicado de manera práctica, casi instintiva, pues conlleva a la exaltación del espíritu. En contraparte, aquello que represente mayor sacrificio sin un "premio" equivalente, quedará en el abandono y desuso. "Por utilidad se entiende la propiedad, en cualquier objeto, por medio de la cual, tiende a producir beneficio, ventaja, placer, bien o felicidad (en el presente caso todas vienen a ser lo mismo), o (lo que igualmente viene a ser lo mismo) para impedir que le ocurran: el perjuicio, el dolor, el mal o la desdicha a la parte cuyos intereses se consideran; 
si esta parte es la comunidad en general, entonces la felicidad de la comunidad; si la de un individuo en particular, entonces la felicidad de ese individuo" (Bentham, 1965, p.179).

Será importante que la implementación técnica se plasme en la realidad y por el mayor beneficio que representa. "Una teoría, en verdad, no es buena hasta en tanto que sus indicaciones no reciban, en su oportunidad, la confirmación de la experiencia” (Bentham, 1965, p.174).

\section{7.- La integridad amenazada: un supuesto de estado de necesidad}

Beccaria ya explicaba en "De los delitos y las penas", la necesidad por una medida rehabilitadora de corta duración y nada nociva para el sujeto infractor:

(...); y esa custodia, siendo esencialmente penosa, debe durar el menor tiempo posible, y ser lo menos dura posible. El menor tiempo debe medirse, tanto por la necesaria duración del proceso, como por la antigüedad de quien antes tiene un derecho a ser juzgado. (...) El proceso mismo debe terminarse en el menor tiempo posible. ¿Qué contraste más cruel que el de la indolencia de un juez y las angustias de un reo? ¿Las comodidades y los placeres de un insensible magistrado por una parte, y las lágrimas y la desolación de un prisionero por otra? En general, el peso de la pena como consecuencia de un delito debe ser lo más eficaz para los demás y lo menos dura que sea posible para quien la sufre; pues no se puede llamar sociedad legítima aquella donde no sea principio infalible, que los hombres se han querido someter a los menores males posibles.

(Beccaria, 2012, p.51).

En primer orden se deben considerar dos principios aplicables a lo desarrollado en el presente numeral, el Principio de Protección Individual, entendido por la defensa de bienes jurídicos individuales, y el Principio de Prevalecimiento del Derecho que Roxin explica:

En la legítima defensa, por ejemplo, los principios de autoprotección y de prevalencia del Derecho son los que sirven de base a la regulación legal. Es decir, todo el mundo tiene el derecho a defenderse de ataques prohibidos de tal manera que no sufra ningún daño. Pero también allí donde puede sustraerse al ataque le está permitido siempre defenderse legítimamente. El principio de prevalencia del Derecho (la idea, por tanto, de que el Derecho no tiene que ceder ante el injusto) va más lejos aquí que los intereses de autoprotección y, desplaza también al principio de ponderación de bienes que, por lo demás, tiene a menudo decisiva importancia en las causas de justificación.

(Roxin, 2000, p.78).

En ese sentido, frente una agresión antijurídica es posible repeler el ataque de manera legítima, ello estabilizará el orden jurídico. Se busca el Prevalecimiento del derecho con racionalidad, es decir -en la medida de lo posible- sin violencia (Roxin, 2000, p.251). “A nadie se 
le puede oponer dificultad alguna para que, viéndose víctima de una acometida incalificable, trate de repeler la fuerza con la fuerza" (Roxin, 2000, p.252).

Para que exista un estado de defensa legítima es necesario defender derechos individuales, bienes jurídicos individuales como la vida, libertad, salud, integridad, custodia, dignidad, derecho sobre la morada, etc. (Roxin, 2000, p.263).

Además, es también un requisito para acudir a la defensa legítima, que la conducta antijurídica sea humana, esto es una: acción u omisión agresiva y antijurídica. Para el caso de estudio, se comenta que la característica propia del Control Formal es el empleo de violencia, la privación de libertad es coercitiva, física y moralmente entendida. Asimismo, es necesario explicar que la medida de internamiento es justificada por la contravención a un riesgo prohibido, es decir, el internamiento es legítimo, no obstante, el maltrato, el hacinamiento, el aislamiento que se sufre en los Programas de Intervención Intensiva y la falta de idoneidad en la labor de rehabilitación, reinserción y resocialización.

La doctrina explica que siendo necesario que la conducta lesiva -sin justificación- sea cometida por una persona humana, es posible determinar para este estudio que el ataque ilegítimo puede ser provocado desde distintas perspectivas: por los demás internos del medio cerrado, educadores, el cuerpo administrativo que permite la contravención de Derechos Humanos en estas instituciones; así también el ente administrativo omite su deber de garante, ya que permite el hacinamiento y el aislamiento.

En ese contexto Roxin establece que la persona agresora, en ciertos momentos utiliza un instrumento (2013, p.266); ejemplifica su postura con el caso de un señor que posee un perro, y la persona se sirve del perro para atacar de manera ilegítima a otra. En consecuencia, podemos afirmar que la persona (educadores, guardianes, personal de los Centros de medio cerrado se sirven del poder de la Administración para castigar y someter a la persona al menoscabo de sus principales bienes jurídicos protegidos.

Se debe resaltar que no es necesario que la agresión configure un delito o infracción penal, solo resulta necesario que la conducta sea contraria a derecho; antijurídica (Roxin, 2000). En ese sentido, las condiciones de internamiento que ofrecen los Centros Juveniles de Diagnóstico y Rehabilitación son contrarias a lo razonable y al derecho, toda vez que se permite una ración de golpes físicos sobre el cuerpo de los jóvenes infractores, se permite además el castigo del 
aislamiento, se toleran índices exacerbados de hacinamiento. El ataque resulta actual, constante y persistente la situación antijurídica en aquellos centros de medio cerrado.

Los jóvenes en conflicto con la ley penal y sus padres o tutores, es para que la Administración rehabilite, reinserte y resocialice; no obstante, no conocen que la actividad rehabilitadora ha sido desplazada por la de contención, sin diferenciación de perfiles criminales, con programas que justifican el aislamiento en una infraestructura hacinada (Roxin, 2000). En diferente orden, la defensa frente a la situación antijurídica que se presenta en los Centros Juveniles debe emplear medios suficientes para repeler el ataque; es decir existe una necesidad racional en el medio empleado para la neutralizar la acción ilegítima. No es posible además alegar una defensa legítima frente a un ataque que resulte del daño de bienes jurídicos supra-personales: familia, correcta administración de justicia, seguridad del Estado, medio ambiente, etc. (Armaza Galdos, 2004).

Adicionalmente Roxin explica que tanto la justificación y la exculpación comparten el animus defensionis. En ese sentido, en las causas de justificación existe una colisión de dos intereses, o bienes jurídicos protegidos, donde uno solo de ellos debe imponerse. La sociedad regula lo que es considerado de mayor y de menor valor, en caso que sean bienes jurídicos con igual preponderancia, el propio actor decide qué deber y quiere cumplir. En consecuencia, la afectación del bien jurídico de menor valor no es un injusto. Es necesaria la colisión de intereses, las pautas de conducta están determinadas en una frontera entre el derecho y el injusto (Roxin, 2013).

Las colisiones más ostensibles las podemos encontrar en:

i.- la legítima defensa

ii.- el estado de necesidad

iii.- facultades del ejecutivo dispersa en leyes (función tuitiva)

iv.- derecho paterno de corrección (hijos)

V.- el consentimiento presunto

vi.- salvaguardia de justos intereses en las lesiones contra el honor (Roxin, 2013, p.230).

En otro orden de ideas, resulta necesario mencionar que la exculpación propone una exclusión de la responsabilidad penal: el autor comete un acto antijurídico (existencia de intereses contrapuestos), y serán causas de exculpación el error de prohibición invencible y el estado de 
necesidad exculpante "La pena se vincula a la culpabilidad, la medida de seguridad a la conducta del autor" (Roxin, 2013, p.235).

El contenido teleológico de la regulación entiende que en todo estado de necesidad existe una ponderación de intereses, que justifican (a) y exculpan (b).

a) Imposición de intereses claramente preponderantes, intereses socialmente provechosos y legales

b) Cuestión jerárquicamente superior que justifica la conducta del autor, función de negar expresamente que el autor pueda ser reprochado y declarado socialmente dañino. "...hace algo que no debe ocurrir según los parámetros del ordenamiento jurídico" “...su conducta no es juzgada como necesitada de pena pese a la desaprobación legal" (Polaino Navarrete, 2004, pp.327-328).

La condición es establecida por una situación de "peligro actual, no conjurable de otro modo" (Polaino Navarrete, 2004, p.334).

Ya la presencia de un "peligro" presupone que es de esperar una cierta afectación al bien jurídico, ...esto rige sobre todo para los así llamados peligros duraderos, en los cuales un estado de peligro amenazante se pierde transformar en cualquier momento en un daño, sin que pueda decirse exactamente cuándo ocurrirá esto; ...pero también constituye un peligro duradero el tirano de la familia, quien de momento está tranquilo, pero que en cualquier momento puede cometer nuevos maltratos.

(Polaino Navarrete, 2004, p.335).

Mutatis mutandis, se refiere que es posible determinar la existencia de un peligro en la deficiente administración de los centros juveniles, acrecentada por el esquema de poder censurado que vulneran bienes jurídicos fundamentales protegidos. En ese sentido Polaino Navarrete que:

Igualmente, un peligro puede ser actual cuando si bien su realización todavía va a tardar, tiene que intervenirse ya en el momento actual si no se quiere que sea demasiado tarde para una defensa; este grupo de casos se superpone frecuentemente con aquellos de peligro duradero... Una exclusión de responsabilidad no entra en consideración cuando el peligro era evitable de otra manera.

(2004, p.336). 


\section{CAPÍTULO VI: MEDIDAS SOCIO-EDUCATIVAS}

\section{1.- Finalidades y características}

En este capítulo se definen conceptos básicos de la ley peruana específica.

En primer orden se establece un límite y diferencia en la responsabilidad penal del adolescente que recoge la legislación vigente; el art. 20 inciso 2 del código penal establece que el menor de 18 años está fuera de los alcances de la Ley penal (exento de la responsabilidad por delito).

Dado que la capacidad penal se desarrolla en virtud del proceso de socialización y que este se verifica con el paso del tiempo, la edad será el primer indicador del nivel de capacidad penal. La ley regula esta situación sobre la base de presunciones. Por un lado, presume iuris et de iure que el menor de catorce años adolece de capacidad penal, aun cuando se acredita en el caso concreto que comprende la ilicitud penal de sus actos y es capaz de inhibirse. Por otro lado, presume iuris tantum que el mayor de catorce años ha alcanzado un grado de desarrollo en que puede empezar a responder pos sus actos ilícitos y prevé, para desvirtuar dicha presunción, un catálogo de circunstancias que pueden conducir a la incapacidad penal o a la atenuación de responsabilidad penal.

(Meini, 2014, p.134).

De esa manera podemos aseverar que la capacidad penal (respecto al indicativo edad) responde al criterio del proceso social, el tiempo es el factor que determina el aprendizaje de las conductas socialmente desvaloradas $^{23}$. En consecuencia, resulta necesario distinguir dos grupos que conforman el grupo de los infractores de la Ley penal: Aquellos menores de 14 años (medidas de protección o seguridad) y mayores de 14 años (medidas socio-educativas). Cabe resaltar que estas medidas tienen el propósito adicional de: separar el criterio de aplicación de la medida socioeducativa de internamiento en modo, lugar y tiempo de la población de menores ${ }^{24}$.

Del mismo modo, como lo explica el artículo núm. 150 del Decreto Legislativo que aprueba el Código de Responsabilidad Penal de Adolescentes (en adelante D.L. núm. 1348), es finalidad de las medidas socio-educativas contener una función pedagógica y formativa, ya que de

\footnotetext{
${ }^{23}$ Los controles informales de socialización (educativo, espiritual y familiar) mantienen un papel muy relevante en este proceso de aprendizaje; no obstante, cuando un menor no tiene acceso a dichos controles es muy difícil que el "proceso de socialización" sea el adecuado.

${ }^{24}$ En la actualidad, pese a la diferencia que existe entre pena privativa de libertad y medida socio educativa, los menores más peligrosos son internados en una cárcel de mayores: Penal Modelo Ancón II. Ello en claro contravención al Artículo núm. 188 del Cód. de los Niños y Adolescentes.
} 
esa manera se facilitará la reinserción del menor a la sociedad. Se establece además que los derechos a la salud, educación y formación profesional no pueden ser limitados o suspendido en la ejecución de las medidas socio educativas.

Es menester incluir la finalidad -anterior a la derogación- que mantenía el artículo núm. 229 del Código de los Niños y Adolescentes (en adelante CNA), aquel numeral identificaba como finalidad primordial a la educación y luego a la función socializadora. También instaba al Juez a tener en cuenta el principio de protección al menor, antes de disponer una sanción ${ }^{25}$.

En adición, según el artículo núm. 153 del D.L. 1348, la medida que determina el internamiento en medio cerrado está condicionada a ciertos criterios que deben ser analizados antes de establecerse:

a) La gravedad de la infracción

b) La magnitud del daño causado

c) El grado de participación del adolescente en la infracción

d) La edad del(la) adolescente al momento de la comisión de los hechos

e) La proporcionalidad, racionalidad e idoneidad de la sanción

f) La capacidad para cumplir la sanción

g) La voluntad del(la) adolescente por reparar los daños

h) La contención y contexto familiar del adolescente

i) Las condiciones personales y sociales del adolescente

En el año 2015 mediante el Decreto Legislativo núm. 1204, se dispusieron modificaciones importantes en el CNA, cabe resaltar que el presente párrafo responde al modelo antiguo donde la determinación de las sanciones era entendida como medidas socio-educativas. Por tanto, existían 5 maneras en las que la Justicia juvenil disponía medidas destinadas a rehabilitar y resocializar al menor infractor. Aquel propósito permitía dotar de dinamismo al sistema de castigo, además brindaba diferentes oportunidades de rehabilitación a los jóvenes en conflicto con la Ley penal. Estas eran las siguientes: la amonestación, prestación de servicios a la comunidad, libertad asistida, libertad restringida y finalmente la internación (MINJUS, 2013).

\footnotetext{
${ }^{25}$ Se debe resaltar que el Código de los Niños y Adolescentes siempre hizo referencias a medidas socio-educativas como el "castigo" que merece un menor infractor; no obstante, el año 2015, con la modificación del Decreto Legislativo núm. 1204, se cambia la denominación de las "medidas socio-educativas" a un tono más severo, desvalido del elemento educativo y resocializador: sanciones. La utilidad y empleo de las denominadas sanciones duraron un aproximado de dos años, ya que la condición de "medida socio-educativa" retorna con el Decreto Legislativo núm. 1348 del año 2017.
} 
Las tres primeras incluían alternativas ajenas al internamiento del menor en un centro especializado de rehabilitación social. Es así que la amonestación estaba destinada a recriminar la conducta infractora, con una finalidad reflexiva para que el menor $-\mathrm{y}$ su familia- mejore sus conductas formativas. La prestación de servicios empleaba al menor por un máximo de 6 meses, tareas que no debía intervenir con la salud, educación o trabajo del menor.

La figura de la libertad asistida incluía la participación de un tutor por el tiempo no mayor de 8 meses, con la intención que guíe, participe y supervise al adolescente y a su familia. En cambio, en la figura libertad restringida necesitaba que el menor participe de manera diaria y obligatoria de un programa de Orientación, con una duración no mayor de 12 meses. Finalmente, el Internamiento, que era considerada como única medida privativa de libertad (MINJUS, 2013). no podía exceder los 6 años; sin embargo, ahora la sanción máxima priva la libertad hasta los 10 años.

Con fecha 23 de setiembre de 2015 se publicó en el Diario Oficial el Decreto Legislativo $\mathrm{N}^{\circ} 1204$, que modifica el Código de los Niños y Adolescentes respecto a las a sanciones a imponer a los adolescentes en conflicto con la ley penal y su ejecución. Muchas son las innovaciones que introduce la modificatoria al Código de los Niños y Adolescentes, desde nuevos conceptos jurídicos (por ejemplo, ahora se habla de sanciones en lugar de medidas socioeducativas), hasta el desarrollo normativo de un variado catálogo de sanciones, algunas de las cuales resultan novedosas en nuestro sistema penal juvenil (mandatos y prohibiciones, reparación directa a la víctima e internación domiciliaria), inclusive se establece la facultad del juzgador para variar, reducir o dejar sin efecto la sanción de internación durante la etapa de ejecución de sentencia.

(García Huayana, 2016, p.2).

\section{2.- Medidas socio-educativas (Decreto Legislativo núm. 1348, 2017)}

Actualmente el Código de Responsabilidad Penal de Adolescentes define en el Título II (artículo núm. 156) los tipos de medidas socioeducativas, divide al apartado en dos grupos:

1.- Medidas no privativas de libertad: Amonestación, libertad asistida, prestación de servicios a la comunidad y libertad restringida.

2.- Internación en un centro juvenil

Adicionalmente los padres o tutores deben de apoyar el cumplimiento y ejecución de la medida que se imponga. Asimismo, se debe resaltar que numeral 156.3 establece que la mayoría de edad adquirida dentro del proceso o en su ejecución, no lo exime de ella. 


\subsection{1.- Medidas accesorias}

El Juez debe señalar la medida accesoria que se puede aplicar a cada caso, la duración de esta medida adicional mantiene la misma duración que la medida socioeducativa aplicada (artículo núm. 157.3).

1. Fijar un lugar de residencia determinado o cambiar el lugar de residencia actual

2. No frecuentar a determinadas personas

3. No frecuentar bares, discotecas o determinados centros de diversión

4. No ausentarse del lugar de residencia sin autorización judicial

5. Matricularse en una institución educativa (pública o privada) o en otra cuyo objeto sea la generación de un oficio o profesión

6. Desempeñar una actividad laboral o formativa laboral

7. No consumir o ingerir bebidas alcohólicas o drogas

8. Internar al adolescente en un centro de salud, público o privado, para tratar la enfermedad adictiva

9. Participar en programas educativos o de orientación; y, otras que el Juez considere adecuada y fundamente en la sentencia condenatoria.

\subsection{2.- Medidas socio-educativas no privativas de libertad}

\section{a) Amonestación}

Ubicada en el artículo núm. 158 del D.L. 1348, explica que debe existir una recriminación directa al menor y a sus padres o tutores. El legislador además busca un compromiso de parte del menor y sus responsables, advirtiendo las consecuencias jurídicas sobre la reiteración de la conducta.

Además del carácter oral de la medida debe acompañarse al menos una indicación escrita de los hechos demostrados en el ínterin del proceso, el derecho vulnerado y los dispositivos relacionados a la sanción que se ha aplicado, pues esto garantiza más efectividad en el cumplimiento de las medidas ordenadas y se satisface el principio de fundamentación suficiente (...) Al tener la calidad de sanción leve y menos restrictiva de los derechos del infractor, corresponde interpretar que se aplicará ante hechos ilícitos que no revelen gravedad y donde no ha existido violencia ni amenaza contra la víctima. El Juez tiene la posibilidad de aplicar esta sanción en aquellos casos en que el bien jurídico afectado no es de carácter fundamental y se considere además, que por las condiciones personales del sujeto resulta la más adecuada.

(García Huayana, 2014, p.41).

En consecuencia, es la sanción más leve, y su ejecución está delimitada en función al acto cometido, solo comprende a las faltas y cuando el hecho punible sea de mínima gravedad. Además, 
si el Juez decide acompañar dicha amonestación con una medida accesoria, la duración de ella, no debe ser mayor de 6 meses.

\section{b) Libertad asistida}

Determinada en el artículo núm. 159 del D.L. 1348 designa al menor la obligación de asistir a programas educativos y orientación por el período mínimo de 6 meses y máximo de 12 meses. La atención debe ser brindada por un especialista con aptitudes en el tratamiento de adolescentes ${ }^{26}$.

El inciso 4 de aquel artículo define una obligación para las entidades donde se ejecuta la medida socioeducativa, la cual implica brindar información periódica (cada 3 meses) al Juez sobre el cumplimiento y evolución de la medida. Al respecto esta obligación necesaria y útil, resultará beneficiosa en tanto el Legislador también haya considerado el aumento en el presupuesto destinado a cubrir los costos generados por la disposición adicional.

\section{c) Prestación de servicios a la comunidad}

Ubicada en el artículo núm. 160 del D.L. 1348, determina que el adolescente debe de realizar ciertas tareas gratuitas de interés social; sin perjudicar su salud, escolaridad ni trabajo. El periodo mínimo y máximo circundan las 8 y 36 prestaciones.

De otro lado, como el objetivo de la medida es básicamente sensibilizar emocionalmente al adolescente, hasta el punto que pueda comprender que está realizando una labor útil a la sociedad. Si dicha medida se aplica de manera coercitiva, estaría revestida de arbitrariedad e inmediatamente cambiaría el significado para el adolescente, quien lo interpretaría como una especie de trabajo forzado" (García Huayana, 2014, p.42).

La finalidad -en cierto modo, retributiva- conlleva una razón educativa donde se enseña a valorar aquello que solo a través del trabajo duro se puede conseguir.

\section{d) Libertad restringida}

La aplicación de esta medida también es llamada de "medio abierto" y formalmente conocida como el Servicio de Orientación al Adolescente (SOA). El artículo núm. 160 del D.L. 1348 determina la asistencia y participación diaria del menor al SOA con la intención que reciba

\footnotetext{
${ }^{26}$ Antes de la modificación surgida por el Decreto Legislativo núm. 1204, el artículo que describía la Libertad asistida incluía a la familia del menor. Para la antigua versión la libertad asistida resultaba útil el control informal (familia del menor) para evitar la permanencia y reiteración de la conducta infractora.
} 
educación, y posibilita la reinserción a la sociedad por los programas y labores que realizan en dicha institución. El período máximo limitador de esta norma es de 1 año.

Se considera que esta medida es muy buena ya que evita el círculo vicioso de renovación automática (self fulfilling prophecy). La teoría criminológica del Etiquetamiento (Cullen, Agnew, Wilcox, 2014, pp.253-275), explica la acentuación del síntoma criminal en tres momentos: en primer lugar la Sociedad define que ciertos comportamientos serán identificados como criminales (infracciones para efectos del estudio), no obstante que algunas personas no podrán y no querrán cumplir con las normas, la definición de las "conductas desviadas" se mantienen en pie. Aquellas personas que cometan conductas desviadas deberán ser separadas de la sociedad; por tanto, la reacción social es de marginalización y etiquetamiento sobre aquellas personas que no podían cumplir con el código de conducta. En aquel momento -de salida de la esfera social- se rompe el vínculo con la sociedad (Social bond theory).

En segunda instancia, la persona etiquetada se ve forzada a asociarse principalmente con los demás marginales y otros infractores (alojados en los centros de medio cerrado). De esa manera la persona desviada se asume como tal, y su interacción diaria será con otros de su similar condición; en aquel momento sucede una alteración en la identidad del infractor (Social learning theory). Por último, el tercer escalón se caracteriza por la etiqueta "infractor" o "ex infractor" y se les niega el retorno a la sociedad: oportunidad laboral (Strain theory).

Por tanto, es posible afirmar que el tiempo que pasa el menor que cometió una conducta es esencial para que él se identifique (cada vez más) con la violencia y síntoma delictivo. Se debe evitar que el adolescente infractor redefina su personalidad en torno al rol desviado (desviación secundaria) (Cullen, Agnew, Wilcox, 2014, p.586).

Es posible deducir que una adecuada reintegración del grupo infractor podría llevarnos en último término a la reducción del índice criminal, ya que un menor rehabilitado es en consecuencia a futuro un delincuente menos. A menor número de infractores o delincuentes, menores los daños que soporta la sociedad: Por tanto, disminución de la ratio criminal.

En consecuencia, el modelo resocializador basado en la Libertad Restringida acierta en cuanto pretende la resocialización dentro de un medio idóneo: en sociedad. 


\subsection{3.- Medidas socio-educativas privativas de libertad}

\section{a) Internamiento}

El artículo núm. 162 del D.L. 1348 determina al internamiento como una medida socioeducativa de carácter excepcional, siempre que se cumpla cualquiera de los siguientes supuestos:

a) Hechos tipificados como delitos dolosos, además que impliquen pena no menor de 6 años y siempre que se coloque en grave peligro bienes jurídicos protegidos como la vida, la integridad física y psicológica.

b) Si el menor infractor haya incumplido de manera injustificada y reiterada las medidas socioeducativas impuestas.

c) La reincidencia en una conducta infractora grave en un lapso que no exceda los dos años.

d) La sentencia condenatoria debe señalar la necesidad, idoneidad y proporcionalidad en la elección del medio cerrado como medio idóneo de medida socioeducativa. Informe preliminar del equipo multidisciplinario donde se indique que el adolescente es peligroso en atención a sus características de personalidad, perfil. Además el hecho punible cometido debe ser doloso y sea sancionado con penas distintas a la privativa de libertad.

\section{b) Duración del internamiento}

El artículo núm. 163 del D.L. 1348 establece una diferencia dentro de la categoría de la responsabilidad penal del menor de edad. Ello en virtud a la edad, el grado de sanción privativa de libertad que merece el adolescente infractor: si es mayor de 14, pero menor de 16, entonces el límite máximo será de 8 años de internamiento; en cambio, para los mayores de 16 y menores de 18 se entiende que el límite son 10 años en los siguientes supuestos excepcionales: Delito de sicariato, violación sexual de menor seguida de muerte o lesión grave y también aquellos delitos comprendidos en el Decreto Legislativo 1348, artículo 163.

La relación de delitos que incluyen esta norma: “(...) y se trate de los delitos tipificados como el parricidio, homicidio calificado, homicidio calificado por la condición de la víctima, feminicidio, lesiones graves (segundo y tercer párrafo), Lesiones graves cuando la víctima es menor de edad, de la tercera edad o persona con discapacidad, lesiones graves por violencia contra la mujer y su entorno familiar, instigación o participación en pandillaje pernicioso, secuestro, trata de personas, formas agravadas de la trata de personas, violación sexual, violación de persona en estado de inconsciencia o en la imposibilidad de resistir, violación de persona en incapacidad de resistencia, violación sexual de menor de edad, robo agravado, extorsión, promoción o favorecimiento al tráfico ilícito de drogas y otros, tráfico ilícito de insumos químicos y productos 
fiscalizados, comercialización y cultivo de amapola y marihuana y su siembra compulsiva, formas agravadas de tráfico de drogas, y cuando sea integrante de una organización criminal, actúe por encargo de ella o se encuentre vinculado a la misma (....)." (Artículo 163.2 del D.L. 1348).

Hay intentos de sobre reacción contra los menores.

Si con el aumento de la criminalidad infantil de los últimos años se percibe recientemente el clamor para rebajar el límite de la mayoría de edad penal a los 12 años, esto no puede naturalmente basarse en una culpabilidad repentinamente descubierta de los que hasta entonces eran inimputables, sino solamente en la necesidad de una prevención más efectiva. Será tarea de la criminología mostrar qué instrumentos de educación y de control social pueden ser aquí aplicados y que, en todo caso, el Derecho penal no es medio idóneo para disciplinar y socializar niños.

(Roxin, 1998, pp.35-36).

\section{3.- Efectos del internamiento en el Código de los Niños y Adolescentes}

Esta investigación se centra en la medida socio-educativa Internamiento, también conocida como "medio cerrado". Por ello, en este apartado se analizarán algunos de los derechos más afectados por la afectación de esa medida sancionadora. En primer lugar, se observará la fractura del derecho a la imagen (como medio de marginación), la falta de consideración en las circunstancias que son determinantes para definir las causas de la afectación del riesgo prohibido, por último, se observará si la medida se desarrolla en un medio idóneo destinando a albergar menores infractores de la ley penal.

En primer término, la normativa del CNA busca la confidencialidad integral, con la finalidad de no atentar contra la imagen e identidad del adolescente (art. 190 del CNA y el art. 18 del DL 1348). Pese a ello, el año 2013, a razón del escape del Centro Juvenil de Diagnóstico y Rehabilitación de Lima (Maranguita) se vulneró el derecho a la imagen del menor identificado con las iniciales A.P.G. (conocido como "Gringasho"), debido a que la mayoría de los medios de comunicación mostraban su semblanza física sin reserva, cuando tenía en aquel momento 17 años de edad (Perú21, 2013).

Así también, antes de imponer el castigo, la norma establece que se debe observar, no solo la gravedad del delito/infracción, sino también las circunstancias que rodean a estos menores (art. 191). El propósito de esta norma afirma la intención resocializadora, espera la rehabilitación del menor y encaminarlo a su bienestar.

Por tanto, se deberá estudiar las circunstancias que rodean a los menores infractores. 
Están presentes en forma general como constituye precedente el abandono, la orfandad, la vida en la calle, la búsqueda de la supervivencia, falta de hogar, hambre, violencia, control del más fuerte (o mayor) del grupo; y en adición a todos estos factores de riesgo, un sesgo social mayoritario que se inclina por la indiferencia colectiva.

La norma se preocupa por el factor de la educación del menor, y ello responde indirectamente a uno de los principios explicados por Beccaria. Su obra define que el propósito que mantiene la privación de libertad responde a la idea educativa (s.f., p.204); se debe enseñar la naturaleza del riesgo prohibido y el análisis de valor que surge en torno a la conducta delictiva. Él consideraba que es más educativo entender y reparar el daño a través del trabajo; de esa manera se podría valorar y aprender el concepto de propiedad privada y finalmente entender sus límites y necesidad de respeto. Este profesor italiano, diría hoy que, si alguien hurtó un teléfono celular, debe de trabajar, juntar el suficiente dinero para comprarlo, y devolverlo a la víctima. El proceso de aprendizaje es completo, pues el menor conocerá el esfuerzo que conlleva conseguir un bien, otorgará valor a su acción y de forma simultánea también al bien; aquello le enseñará los límites del respeto hacia lo que no le pertenece.

Asimismo, es necesario comentar el rol que cumple la Remuneración Mínima Vital (en adelante RMV $)^{27}$ en la labor educadora de los padres y tutores. Esta asignación mínima es utilizada por los empleadores y ella -por su precariedad- no permite construir un hogar, mantener una vida independiente y afrontar los gastos que los hijos suman a la ecuación del desarrollo familiar. La RMV es suficiente para una sola persona, muy joven, con una vivienda que represente 200 soles, unos servicios básicos de 50 soles, alimentación básica de 560 soles mensuales (140 soles semanales, 20 soles diarios que incluyen desayuno, almuerzo y cena). Reunidos aquellos montos se llega a la cantidad de 810 soles.

En tal escenario, no hay posibilidad para búsqueda de cultura, es imposible comprar un libro, tener un seguro médico, atender al cuidado dental; es muy difícil cubrir las necesidades básicas con un ingreso ínfimo. Debemos sumar que la mayoría de los peruanos no tienen educación escolar básica completa, el universo de criminales muestra estos matices, falta de educación sumada a muy bajos ingresos económicos. Dos cuadros estadísticos evidencian la situación de pobreza y la precaria educación que existe en el país.

\footnotetext{
${ }^{27}$ Para el año 2016, fue fijada con el monto de 850 soles.
} 
Tabla 6.1.

Pobreza: Población con al menos una necesidad básica insatisfecha, según ámbito geográfico, $2007-2015$

\begin{tabular}{|c|c|c|c|c|c|c|c|c|c|c|c|c|}
\hline \multicolumn{13}{|c|}{ POBREZA } \\
\hline \multicolumn{13}{|c|}{ POBLACIÓN CON AL MENOS UNA NECESIDAD BÁSICA INSATISFECHA, SEGÚN ÁMBITO GEOGRÁFICO, 2007 - 2015} \\
\hline \multicolumn{13}{|c|}{ (Porcentaje respecto del total de población de cada año) } \\
\hline \multirow{3}{*}{ Ámbito Geográfico } & \multirow{3}{*}{2007} & \multirow{3}{*}{2008} & \multirow{3}{*}{2009} & \multirow{3}{*}{2010} & \multirow{3}{*}{2011} & \multirow{3}{*}{2012} & \multirow{3}{*}{2013} & \multirow{3}{*}{2014} & \multirow{2}{*}{\multicolumn{4}{|c|}{\begin{tabular}{|c|c|}
\multicolumn{2}{|c|}{2015} \\
Estimación Intervalo de confianza al 95\%
\end{tabular}}} \\
\hline & & & & & & & & & & & & \\
\hline & & & & & & & & & & Inferior & Superio & $\mathrm{CV}(\%)$ \\
\hline Total & 30.3 & 28.9 & 26.8 & 23.9 & 23.3 & 21.6 & 20.3 & 19.7 & 19.4 & 18.6 & 20.2 & 2 \\
\hline Lima Metropolitana & 11.6 & 12.7 & 12 & 9.8 & 11 & 9.5 & 9.3 & 9.6 & 8.4 & 7.2 & 9.8 & 7.9 \\
\hline Resto Pais & 38.4 & 35.9 & 33.4 & 30.2 & 28.8 & 27 & 25.4 & 24.4 & 24.4 & 23.5 & 25.4 & 2 \\
\hline \multicolumn{13}{|l|}{ Área de residencia } \\
\hline Urbana & 19.1 & 19.5 & 18.6 & 15.8 & 15.8 & 14.4 & 14 & 13.9 & 13.7 & 12.9 & 14.6 & 3.2 \\
\hline Rural & 59.1 & 53.5 & 49.6 & 46.5 & 44.9 & 43 & 39.7 & 37.9 & 37.7 & 36 & 39.4 & 2.3 \\
\hline \multicolumn{13}{|l|}{ Región Natural } \\
\hline Costa & 16.4 & 17.5 & 16.5 & 14 & 14.5 & 12.9 & 12.1 & 12 & 11.3 & 10.4 & 12.3 & 4.3 \\
\hline Sierra & 41.9 & 36.5 & 32.5 & 28.8 & 27.4 & 26 & 23.6 & 22.4 & 22.6 & 21.2 & 24 & 3.1 \\
\hline Selva & 57.3 & 56 & 55 & 52.5 & 49.6 & 46.9 & 46.2 & 45.7 & 45.6 & 43.2 & 48 & 2.7 \\
\hline \multicolumn{13}{|l|}{ Dominio Geográfico } \\
\hline Costa Urbana & 18.7 & 20 & 18.7 & 16 & 16 & 14.5 & 14.1 & 13.4 & 13.6 & 12.2 & 15.2 & 5.6 \\
\hline Costa Rural & 47.1 & 45.9 & 45.9 & 44.3 & 40.8 & 37.6 & 30.4 & 28.6 & 27.7 & 23.6 & 32.2 & 7.9 \\
\hline Sierra Urbana & 23 & 20 & 20 & 15.9 & 15.1 & 14.1 & 13.1 & 12.9 & 13.8 & 12.1 & 15.6 & 6.4 \\
\hline Sierra Rural & 57.2 & 49.5 & 43.3 & 40.2 & 38.6 & 37.2 & 34 & 32 & 31.7 & 29.8 & 33.7 & 3.2 \\
\hline Selva Urbana & 44.9 & 44.2 & 42.2 & 41 & 36.7 & 34.8 & 35 & 35.4 & 35.5 & 32.5 & 38.5 & 4.3 \\
\hline Selva Rural & 71.3 & 70 & 70.4 & 66.7 & 66.2 & 63.3 & 61.6 & 60.3 & 60.6 & 56.9 & 64.3 & 3.1 \\
\hline
\end{tabular}

Instituto Nacional de Estadística Informativa INEI. (2016). Población con al menos una necesidad básica insatisfecha, según ámbitos geográficos. Estadísticas. Sociales. Pobreza y gasto social. Pobreza. Fecha de consulta: 28/05/17. Recuperado de: https://www.inei.gob.pe/estadisticas/indice-tematico/sociales/

El cuadro anterior permite confirmar lo comentado líneas arriba, observamos que para el año 2014, cerca al 20\% de personas aún no cubrieron sus necesidades básicas; no obstante, este número que abarca el total de la población es más elevado cuando atendemos de manera específica cada región del país. Por ejemplo, en la Selva, donde se estima que casi la mitad de su población (45.6\%) se mantiene sin satisfacer todas sus necesidades básicas. 
Tabla 6.2.

Universidades: Número de graduados y titulados de Universidades Públicas y Privadas, 1985-2014

\begin{tabular}{|l|c|c|c|c|c|c|}
\hline \multicolumn{7}{|c|}{ UNIVERSIDADES } \\
\hline \multicolumn{7}{|c|}{ NÚMER DE GRADUADOS Y TITULADOS DE UNIVERSIDADES PÚ BLICAS Y } \\
PRIVADAS, 1985 - 2014 \\
\hline \multirow{2}{*}{ AN NoS } & GRADUADOS DE UNIVERSIDADES & TITULADOS DE UNIVERSIDADES \\
\cline { 2 - 7 } & TOTAL & PÚBLICAS & PRIVADAS & TOTAL & PÚBLICAS & PRIVADAS \\
\hline 2007 & 72113 & 39064 & 33049 & 52318 & 27118 & 25200 \\
\hline 2008 & 76384 & 43779 & 32605 & 55844 & 32259 & 23585 \\
\hline 2009 & 75546 & 38350 & 37196 & 56728 & 29917 & 26811 \\
\hline 2010 & 82838 & 42116 & 40722 & 60750 & 30734 & 30016 \\
\hline 2011 & 96011 & 48447 & 47564 & 64204 & 31729 & 32475 \\
\hline 2012 & 97658 & 46600 & 51058 & 69020 & 32559 & 36461 \\
\hline 2013 & 101327 & 48875 & 52452 & 70883 & 34158 & 36725 \\
\hline 2014 & 113435 & 50480 & 62955 & 74844 & 34773 & 40071 \\
\hline
\end{tabular}

Fuente: Asamblea Nacional de Rectores (ANR) - Dirección de estadística. Instituto Nacional de Estadística Informativa INEI. (2016). Número de graduados y titulados de las universidades del país. Estadísticas. Sociales. Educación. Universidades. Fecha de consulta: 28/05/17. Recuperado de: https://www.inei.gob.pe/estadisticas/indice-tematico/sociales/

En otro aspecto, el acceso a la educación y la posibilidad de culminar los estudios profesionales también arrojan una data desalentadora, ya que de los 31'038,000.00 millones de peruanos (Banco Mundial, 2016), solo 188,279.00 mil pudieron al menos culminar la carrera universitaria (de los cuales 74,844.00 mil son graduados).

Ahora bien, afrontar un periodo de crisis empuja al acreedor de una RMV a una situación extrema. Una enfermedad simula el periodo de crisis. Se necesita de un seguro, disponibilidad de tiempo y dinero. Ello supone varias complicaciones adicionales, como las presentadas en un empleo informal o independiente: no se aceptará la falta de días, no contiene un depósito de CTS, vacaciones pagadas, etc.

En consecuencia, para el grueso de nuestra población no es posible soportar un periodo de crisis, se buscan alternativas en los préstamos de los intereses y condiciones abusivas, se pide ayuda a los amigos o familiares. En los casos donde se agotan las posibilidades de salida, adoptar comportamientos ilegales se vuelve una tentación; ser criminal se convierte en una opción.

En otro orden de ideas, el concepto de internación preventiva definido por la ley (art. núm. 211) incluye la labor de garante que tiene el Estado en la seguridad del menor. Sin embargo, no se puede tolerar que en la búsqueda de la seguridad el castigo corporal sea utilizado. Además, la 
mezcla de adolescentes que existe en todos los Programas del medio cerrado, permite la convivencia de infractores que cometieron un hecho grave (que sería delito si fuera un adulto), junto a otros adolescentes no violentos ni peligrosos. Del mismo modo, aquella convivencia, también permite que en los ambientes sea posible encontrar a menores de edad junto a otros jóvenes ya mayores de edad. Por tanto, se deduce que el Estado no puede honrar el principio de seguridad, más bien, expone y obliga a una convivencia no diferenciada que no discrimina la gravedad del delito/infracción ni la edad del infractor.

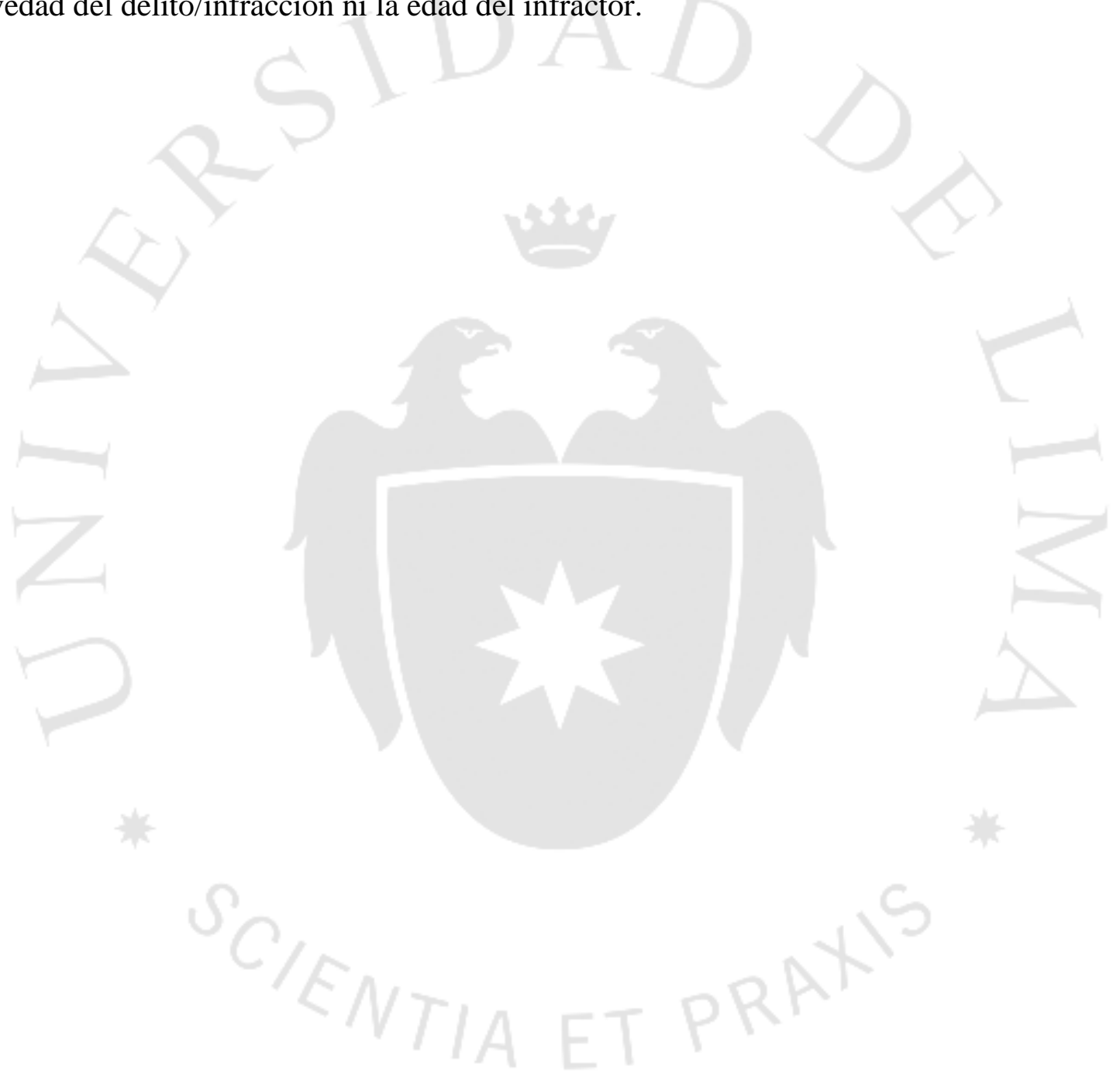




\section{CAPÍTULO VII: JUSTICIA RESTAURATIVA}

\section{1.- Concepto y principales características}

La Justicia Restaurativa nace del movimiento que surge en Estados Unidos de Norteamérica y Canadá, en las décadas de los años 60's y 70's a consecuencia de las constantes críticas al sistema penitenciario, en especial al sistema de justicia juvenil (Crisis en Justicia Juvenil en Estados Unidos, caso Gault año 1967, Corte Suprema) (Llobet, 2005). Se plantea una mediación comunitaria entre el delincuente y la víctima, con el objeto de reestablecer la paz en la Sociedad (Llobet, 2005). La publicidad daba un mensaje: nothing works $^{28}$, y era relativa a la incapacidad penal de eliminar o mitigar el problema criminal. Ello causó en aquella Sociedad (inmersa e influencia por posturas radicales de guerra y movimientos pacifistas) se establecieran dos alternativas de solución, una pedía un endurecimiento en el ordenamiento penal con la implementación de castigos más severos, admitir la pena de muerte para menores, así también la posibilidad de que ellos puedan ser condenados con cadena perpetua.

Por otro lado, un diferente sector influenciado por el escepticismo, apostó por una medida restaurativa, donde la víctima, el delincuente y la comunidad serían los actores principales de la reforma. Es decir, el modelo conocido e imperante aún en el Perú, de Justicia Retributiva (es la Sociedad la afectada y el delincuente debe de someterse a un castigo por haber realizado un riesgo intolerable o prohibido) debería de mutar para convertirse en una de Justicia Restaurativa, donde la víctima es la principal afectada y ella debe ser reparada, debe también ser reintegrada a la Sociedad y que exista la seguridad que no vuelva a suceder una futura y adicional victimización (Llobet, 2005).

El primer proyecto de Justicia Restaurativa se llevó a cabo en Ontario-Kitchener, en él unos jóvenes dañaron 22 propiedades (Llobet, 2005), se realizaron actos de vandalismo. Se trabajó con los fundamentos de esta justicia y se logró que los jóvenes reconocieran su responsabilidad, se evitó que los menores ingresen al sistema penal, pero sí pudieron realizarse reuniones donde la víctima explicaba los daños, demostraba sus sentimientos y de esa manera el transgresor de la norma podía entender la magnitud del daño. En seguida, se buscó que los jóvenes reparen los daños

\footnotetext{
${ }^{28}$ Nada funciona
} 
causados, no obstante, no podían reparar los 22 hogares puesto que no contaban con los recursos suficientes. Por ello, la comunidad, brindó las herramientas necesarias para que los jóvenes cumplan su propósito. Al realizar la conducta de reparación, los menores pudieron conocer el esfuerzo, tiempo y dedicación que demandaba la creación y cuidado de la propiedad.

Una vez finalizada la labor, el daño queda reparado, la víctima conoce las razones, acepta las disculpas y es reintegrada a la sociedad (la víctima entiende que el menor infractor es producto de la comunidad en la que ella vive y se desarrolla). Asimismo, el menor no queda expuesto a ningún contacto con el sistema penal, sin estigmatización ni antecedentes. No existen estigmas que acompañen al infractor durante la ejecución reparadora, es también un modo de aprendizaje eficaz. Se evita el efecto etiquetador de la privación de la libertad (Llobet, 2005).

La también conocida Restorative Justice toma preponderancia desde el año 1993 en el Congreso Internacional de Criminología de Budapest. Influenciada por la corriente Minimalista derivada de la Criminología Crítica- determina que la Sociedad cumple un rol preponderante en la creación de las conductas criminales, y la respuesta estatal frente a los actos denominados como desviados se han centralizado en un segmento especial de la población (la más vulnerable, de escasos recursos y con poca información) (Tailor, Walton, Young, 1997); dando como resultado un uso amplio y discriminado del medio cerrado, con poca eficiencia y rehabilitación; más bien, con un incremento en la reincidencia.

No obstante, la influencia minimalista, la doctrina relaciona a la Justicia Restaurativa como propia del abolicionismo (Llobet, 2005). Toda vez que la Justicia Retributiva generaba un conflicto entre Estado y autor, cuando en realidad, existe un conflicto entre la víctima y el autor (Llobet, 2005).

Sin embargo, debe reconocerse que, en general, los partidarios de la justicia restaurativa no pretenden la eliminación de la justicia penal, por lo que no llegan al abolicionismo de éste, de modo que el sistema penal se mantiene, dejándose que se produzca una desformalización hacia la obtención de una solución al conflicto por la víctima y el autor, a través del diálogo y acuerdo entre ellos. (...), la que no puede ser catalogada como abolicionista, ya que no se pretende la eliminación del Derecho penal juvenil y de la imposición de sanciones a través del mismo, aunque se pretende una restricción de dichas sanciones y la búsqueda de alternativas, cuando es posible, a la imposición de sanciones propiamente dichas, fomentándose con ello la reparación del daño.

(Llobet, 2005, pp.878-879).

En ese sentido, las corrientes restaurativas incluyen un modelo integral donde están presentes las víctimas, agresores y la comunidad. Estos tres actores, son esenciales para que la 
Justicia Restaurativa funcione. La víctima deberá ser reparada, el agresor deberá entender y mitigar el daño causado y la comunidad tendrá la responsabilidad de detectar por qué el agresor cometió un daño y qué hacer para que no se vuelva a reiterar. De esa manera, se podrá prevenir la comisión de nuevos delitos/infracciones, se romperá la cadena de etiquetamiento, estigmatización y se crearán círculos virtuosos de renovación automática.

La Justicia Restaurativa incluye tres posturas:

a) Incapacidad del sistema legal: La respuesta más utilizada es el internamiento en un medio cerrado, y la sociedad olvida que la persona que ha delinquido es producto de una comunidad determinada (Hernández, 2012).

b) Victimología: Traducido como las necesidades que toda víctima adquiere cuando mantiene un daño por un acto criminal, ellas son:

- Verdad: Merece saber lo acontecido, en circunstancia, grado y gravedad.

- No impunidad: Que el acto merezca una sanción adecuada.

- Conocimiento: Entender que el acto criminal fue producto de la comunidad de la que la víctima también forma parte.

- Cambio y reparación: En la medida de lo posible, pronta y óptima reparación del bien jurídico protegido.

- Garantía de no repetición: Evitar el contacto diferencial

c) Efectos y resultados del tratamiento de medio cerrado: Cuando una persona ingresa a un medio cerrado, la sociedad lo identifica como un criminal, está rodeado de personas que mantienen el mismo estatus, y al verse inmerso en el medio y con la identificación de quienes lo rodean son también de criminales, entonces, la persona internada en el medio cerrado se asume como un criminal más, adquiere el estatus (criminalización secundaria). El sistema penal alberga efectos estigmatizantes y criminalizadores "en lugar de rehabilitar favorece a la reincidencia" (Hernández, 2012, p.234).

Por otro lado, se reconoce con un carácter secundario que la conciliación tiene efectos de prevención general positiva, realizándose un aporte significativo en la recuperación de la paz jurídica, debido a que solamente cuando el hecho ha sido reparado, la víctima y la generalidad consideran superada la perturbación social generada por el hecho. Se parte así de la innecesaridad de la imposición de una sanción propiamente dicha, ella ya que los fines que se perseguirían a través de ella pueden ser obtenidos a través del acuerdo entre autor y víctima.

(Llobet, 2005, pp.880-881). 
A propósito Liebmann señala que: “...el énfasis circunda la reparación de la víctima y de la comunidad en lugar de castigar al agresor. ...La justicia restaurativa aspira restaurar el bienestar de las víctimas, los agresores y la comunidad dañadas por el crimen, y así prevenir mayores ofensas" (Liebmann, 2007, p.25).

En síntesis, la Justicia Restaurativa involucra tanto a la víctima, como al delincuente y a la comunidad. Para que este modelo de hacer justicia funcione, debe de existir esforzado trabajo para solucionar el conflicto y reparar el daño ocasionado (búsqueda de reconciliación social). Por último, se espera que prevenga que lo ocurrido vuelva a suceder. Hernández Alarcón utiliza la letra " $R$ " en tres oportunidades para simplificar aún más las características esenciales de esta tendencia: Responsabilidad del autor. Restauración de la víctima. Reintegración del infractor en la comunidad (Hernández, 2012). "Así se ha constatado en algunos proyectos de los Estados Unidos de Norteamérica en que los jóvenes que establecieron contacto con la víctima y realizaron prestaciones de reparación fueron significativamente menos reincidentes que los jóvenes que no accedieron a establecer los contactos correspondientes en el marco de las penas suspendidas a prueba" (Llobet, 2005, p.881).

Por tanto, una de las herramientas que utiliza la Justicia Restaurativa es la Remisión.

Se incorpora por Reglas Mínimas de las Naciones Unidas para la administración de la justicia juvenil, adoptadas en 1985. ...las legislaciones posteriores incorporan otros mecanismos como el principio de oportunidad, la conciliación y la suspensión del proceso de prueba. ...la característica común es que en todas las legislaciones se trata de mecanismos procesales (judiciales).

(Chunga, 2007, p.54).

$\mathrm{Al}$ respecto una prestigiosa ONG del Perú señala lo siguiente:

En el Perú, la experiencia de justicia juvenil restaurativa ha dado buenos resultados, se ha logrado atender a cerca de 2000 adolescentes infractores, con una tasa del $7.5 \%$ de reincidencia, lo cual ha merecido el reconocimiento, por dos años consecutivos, con el premio a las buenas prácticas gubernamentales en la categoría de seguridad ciudadana. En la actualidad, el Ministerio Publico está expandiendo esta experiencia a las ciudades con mayor incidencia de infracciones, con buenos resultados. En Lima: El Agustino, San Juan de Miraflores, Villa El Salvador, Villa María del Triunfo. Otras ciudades: Chiclayo, Trujillo y Chimbote. Y tiene previsto incluir a otras localidades del país.

(Terre des hommes, 2012, p.5).

Así mismo, para el año 2015, la Fiscalía de la Nación en su Anuario estadístico, demostró que existen 892 jóvenes que fueron atendidos por el Programa Estratégico: Justicia Juvenil Restaurativa del Ministerio Público 2015. 
Tabla 7.1.

Perú: Programa estratégico: Justicia Juvenil Restaurativa del Ministerio Público 2015

\begin{tabular}{|c|c|c|}
\hline \multicolumn{2}{|c|}{$\begin{array}{c}\text { PERÚ: PROGRAMA ESTRATÉ GICO: JUSTICIA JUVENIL } \\
\text { RESTAURATIVA DEL MINISTERIO PÚBLICO 2015 }\end{array}$} \\
\hline $\begin{array}{c}\text { DISTRITO } \\
\text { FISCAL }\end{array}$ & $\begin{array}{c}\text { TOTAL DE } \\
\text { JUTICIABLES } \\
\text { ATENDIDOS }\end{array}$ & $\%$ \\
\hline TOTAL & $\mathbf{8 9 2}$ & $\mathbf{1 0 0}$ \\
\hline La Libertad & 125 & 14.1 \\
\hline Lambayeque & 132 & 14.8 \\
\hline Lima & 214 & 23.9 \\
\hline Lima Este & 84 & 9.42 \\
\hline Lima Sur & 248 & 27.8 \\
\hline Santa & 89 & 9.9 \\
\hline
\end{tabular}

Fuente: Ministerio Público - Fiscalía de la Nación. (2015). Perú: Programa estratégico: Justicia juvenil restaurativa del Ministerio Público 2015. En Anuario estadístico. Racionalización y estadística. Lima. Pág. 192.

Para Marian Liebmann, la Justicia Restaurativa puede ser entendida como una postura en contra del castigo, que restaura a la víctima y a la Comunidad. Explica que la persona que vulnera la norma debe conocer el impacto del daño cometido, y de esa manera (la Comunidad y víctima) brinden una oportunidad para reparar el bien jurídico protegido que resultó mermado. Es una justicia que transforma, ya que se puede transformar el delito/infracción en algo diferente, y la experiencia traumática puede resultar en sanadora para ambos -delincuente y víctima- (Liebmann, 2007).

Además, Liebmann propone principios de la actividad restaurativa:

1.- Ayuda/apoyo a la víctima: La "curación” es una prioridad (aunque ello es obvio, para el sistema de Justicia Retributiva y la Sociedad, todo se centra en el delincuente; lo estudiamos, debatimos sobre sus orígenes, cómo eliminarlos, cómo castigarlos, etc.). El sistema actual está pendiente del delincuente y no de la víctima. (Desde la perspectiva del autor de esta investigación, por lo menos no suficientemente de la víctima).

2.- Delincuentes asumen responsabilidad de lo que han hecho: Es el punto de partida para la Justicia Restaurativa. Se debe de cambiar el pensamiento "ya pagué la deuda a la Sociedad", por una nueva donde se tenga presente a la víctima; el infractor debe comprender la magnitud del daño ocasionado. 
3.- Debe de existir un intento por corregir el daño: La Comunidad y el Estado deben brindar la ayuda necesaria para que se pueda e incentive la reparación del daño. Muchas veces el nivel socio-económico del infractor, no posibilita la reparación; en ese contexto, la ayuda comunal o estatal mitigará las carencias del sujeto activo.

4.- Delincuentes aprenden a evitar futuros delitos: La persona que vulnera la norma -por medio de la reparación y la interacción con la víctima- entiende y valora el bien jurídico protegido dañado; se comprende su naturaleza como condición necesaria para el desarrollo de la persona. Producto de la interacción, la víctima comprende que el infractor de la norma penal es producto también de la Comunidad, y que las causas de su acción responden muchas veces a las carencias relacionadas a la mínima redistribución de ganancias.

5.- La Comunidad ayuda a reintegrar a la víctima y al delincuente: Sirve de mediador y posibilitador de la reparación idónea y oportuna (Liebmann, 2007).

Liebmann en aquel contexto, explica que los beneficios derivados de la actividad restaurativa mantienen los 4 actores principales de la actividad criminal. La víctima es beneficiada porque conoce los motivos del daño, recibe disculpas, pregunta razones, se da cuenta del conflicto, recupera el bien jurídico protegido (para ciertos casos) y supera el crimen. El beneficio para el delincuente/infractor se produce cuando entiende el dolor de la víctima, percibe las consecuencias de su actividad y acepta de manera responsable su autoría, pide perdón y/o repara, mejora su futuro. Para las cortes el beneficio también es notable, ya que existirá más conciencia en el castigo y ello generará sentencias más realistas, conocerán cómo son afectadas las víctimas y les brindarán un papel preponderante en el sistema. Finalmente, la Comunidad también se beneficia, pues elimina de su praxis a la violencia y al castigo, acepta perdón y/o reparación y ayuda con la labor reintegradora, tanto del sujeto activo como del pasivo (Liebmann, 2007).

Se resalta que esta medida es optativa en la mayoría de los sistemas de control formal; sin embargo, mantiene el carácter de obligatoria en Austria, Nueva Zelanda y Noruega; el sistema judicial solo se activará cuando la Justicia Restaurativa no funcione (Liebmann, 2007). 
Asimismo, Liebmann expone un cuadro comparativo donde se observan los mayores cambios entre la conocida y practicada Justicia Retributiva y la Justicia Restaurativa:

Tabla 7.2.

Justicia Retributiva y Nuevo paradigma: Justicia Restaurativa

\begin{tabular}{|c|c|c|}
\hline & Justicia retributiva & Nuevo paradigma: Justicia restaurativa \\
\hline 1 & Delito definido como violación del Estado & Delito definido como violación de una persona por otra \\
\hline 2 & $\begin{array}{l}\text { Se centra en establecer la culpa, en pasado (¿él/ella lo } \\
\text { hizo?) }\end{array}$ & $\begin{array}{c}\text { Se centra en la resolución de problemas, en la } \\
\text { responsabilidad y obligaciones del futuro (¿qué se debe } \\
\text { hacer?) }\end{array}$ \\
\hline 3 & Relaciones contradictorias y procesos normativos & Diálogo y negociación normativa \\
\hline 4 & $\begin{array}{c}\text { Imposición de dolor a través del castigo, con el propósito } \\
\text { de disuadir/prevenir }\end{array}$ & $\begin{array}{l}\text { La restitución como un medio para restaurar a ambas } \\
\text { partes. Reconciliación / restauración como meta }\end{array}$ \\
\hline 5 & $\begin{array}{l}\text { Justicia definida por la intención y por el proceso: reglas } \\
\text { correctas }\end{array}$ & $\begin{array}{l}\text { Justicia definida como relaciones correctas y debidas; } \\
\text { Juzgadas por el resultado }\end{array}$ \\
\hline 6 & $\begin{array}{c}\text { La naturaleza interpersonal y conflictiva del crimen } \\
\text { oscurecido, reprimido: el conflicto visto como individuo } \\
\text { contra estado }\end{array}$ & $\begin{array}{l}\text { El crimen reconocido como conflicto interpersonal: el } \\
\text { valor del conflicto reconocido }\end{array}$ \\
\hline 7 & Un daño social reemplazado por otro & Focalización \\
\hline 8 & $\begin{array}{l}\text { Comunidad en linea lateral, representada de forma } \\
\text { abstracta por Estado }\end{array}$ & Comunidad como facilitador en el proceso restaurativo \\
\hline 9 & Fomento de valores competitivos e individualistas & Fomento de la mutualidad \\
\hline 10 & $\begin{array}{c}\text { Acción dirigida del Estado al delincuente: } \cdot \text { victima } \\
\text { ignorada } \cdot \text { delincuente pasivo }\end{array}$ & $\begin{array}{c}\text { El papel de la victima y del delincuente reconocido tanto } \\
\text { en el problema como en la solución: - se reconocen los } \\
\text { derechos / necesidades de las victimas; se alienta al } \\
\text { infractor a asumir la responsabilidad }\end{array}$ \\
\hline 11 & $\begin{array}{l}\text { La responsabilidad del delincuente se define como la } \\
\text { adopción del castigo }\end{array}$ & $\begin{array}{l}\text { Responsabilidad de los infractores definida en la } \\
\text { comprención del impacto de la acción y en la ayuda y } \\
\text { desición ¿cómo hacer las cosas bien? }\end{array}$ \\
\hline 12 & $\begin{array}{c}\text { Delito definido en términos puramente juridicos, } \\
\text { desprovisto de dimensiones morales, sociales, } \\
\text { económicas y politicas }\end{array}$ & $\begin{array}{l}\text { Delito entendido en todo su contexto: moral, social, } \\
\text { económico y politico }\end{array}$ \\
\hline 13 & $\begin{array}{l}\text { La "deuda» debida al Estado y a la sociedad en } \\
\text { abstracto }\end{array}$ & La deuda/responsabilidad ante la victima reconocida \\
\hline 14 & $\begin{array}{l}\text { La respuesta se centró en el comportamiento pasado del } \\
\text { infractor }\end{array}$ & $\begin{array}{c}\text { La respuesta se centra en las consecuencias perjudiciales } \\
\text { en el comportamiento del delincuente }\end{array}$ \\
\hline 15 & $\mathrm{El}$ inamovible estigma del crimen & $\begin{array}{l}\text { La eliminación del estigma en el crimen, a través de la } \\
\text { acción restaurativa }\end{array}$ \\
\hline 16 & No alienta el arrepentimiento ni el perdón & Brinda posibilidades de arrepentimiento y perdón \\
\hline 17 & Dependencia del profesional delegado & Participación directa de los participantes \\
\hline
\end{tabular}

Fuente: Liebmann, Marian. (2007). Restorative Justive How it works. UK, London: Jessica Kingsley Publishers.

Pág. 32. Recuperado de: http://www.8-926-145-87-01.ru/wp-

content/uploads/2014/07/Marian_Liebmann_Restorative_Justice_How_It_WorkBookZZ.org_pdf

En ese sentido Rita Aurora Mill, expone que: "El desafío es superar la lógica del castigo,

pasando a una lectura relacional del fenómeno criminal, entendido primariamente como un conflicto que provoca la ruptura de expectativas sociales simbólicamente compartidas" (Mill, 2013, p.216). 
Resulta necesario distinguir los conceptos de mediación (mediador) y de conciliación (conciliador), ambos, propios de la Justicia Restaurativa, cabe señalar que parte de la doctrina utilizan indistintamente ambos términos diferencia (Mill, 2013):

Se me explicó que el mediador no tenía acceso al expediente penal, porque no podía involucrarse en la faz jurídica, ni proponer soluciones a las partes, porque solo cabía a ellas encontrarlas. Por el contrario, el conciliador debe acceder a las actuaciones judiciales, ya que está entre sus facultades la de proponer opciones de solución a los involucrados en el conflicto. Al parecer, la mediación, en caso de fracasar, sería una instancia previa a la conciliación. (...) Se entiende por Conciliación el proceso en el que uno o más conciliadores, asisten a las partes en conflicto, para facilitar las vías de diálogo, proponiendo alternativas y soluciones al conflicto.

(Mill, 2013, pp.219-220).

Cabe mencionar, que la Remisión no debe ser entendida como una medida que ayuda a la celeridad procesal, es más bien garante y principal herramienta de la Justicia Restaurativa.

\section{2.- Remisión}

Como líneas arriba se menciona, la Remisión es una herramienta de la Justicia Restaurativa, aleja al menor del sistema penal y brinda una oportunidad de resocialización en libertad. “...funciona dentro de los criterios de oportunidad como alternativa al proceso judicial en sí mismo (mecanismo de diversión, desformalización o desjudicialización) y además, como auténtica salida alternativa frente a la respuesta punitiva, que de iniciarse y culminar el proceso judicial probablemente le sería impuesta" (Hernández, 2012, p.237). Asimismo:

A través de la remisión pueden llegarse a favorecer soluciones de justicia restaurativa, aunque debe anotarse que la remisión implica que éstas se den fuera del ámbito de la justicia penal juvenil, lo que es concordante con la concepción de la justicia restaurativa tal y como se da en los Estados Unidos, en donde intervienen organizaciones privadas en la mediación.

(Llobet, 2005, p.883).

A propósito, García Huayama, propone la “Aplicación de la Remisión Judicial y con ello la aplicación de cualquier medida en libertad, de conformidad con lo previsto en los artículos 223 y 228 del Código de los Niños y Adolescentes, entre las cuales debe preferirse la prestación de servicios a la comunidad y la reparación directa a la víctima por medio de la instalación de la mediación” (García Huayama, 2016, p.250). 
La diferencia entre un menor y un adulto o mayor que delinquen, no debe ser una reacción cuantitativa del ordenamiento, sino cualitativa: no más o menos pena, por ser mayor o menor el delincuente, sino que el caso del menor debe primar la corrección, porque su actuación es producto de un fracaso de la educación y socialización que se le haya dispensado, así como que aún es tiempo de rectificar errores. La resocialización, debe insistirse en ello, es aún más importante en los menores que en los mayores, por su necesidad y por sus posibilidades de éxito.

(Álvarez Alarcón, 2004, p.304).

Esta tesis se apoya en el pedido generado en el ámbito europeo, toda vez que la recomendación núm. R (87) 20 del Comité de Ministros del Consejo de Europa (de fecha 18 de septiembre de 1987) señala que:

\section{Desjudicialización (diversión) - mediación}

(...se debe...) 2. Alentar el desarrollo de procedimientos de desjudicialización y de mediación a nivel del órgano de prosecución (clasificación sin persecución) o a nivel policial, en los países donde la Policía tenga funciones de persecución, a fin de evitar a los menores la asunción por el sistema de justicia penal y las consecuencias derivadas de ello; asociar a los servicios o comisiones de protección de la infancia a la aplicación de estos procedimientos.

3. Adoptar las medidas necesarias para que en el curso de estos procedimientos:

.se aseguren la aceptación por el menor de las eventuales medidas que condicionan la desjudicialización y, si es preciso, la colaboración de su familia;

.se conceda una atención adecuada tanto a los derechos e intereses de la víctima como a los del menor.

(Comité de Ministros de los Estados Miembros, 1987).

\section{a) Finalidad}

La Remisión tiene como meta evitar que el adolescente infractor ingrese al sistema penal. Existen tres requisitos por los cuales un menor debe ser separado de la medida internamiento.

(ii) Compromiso del adolescente infractor y de los padres a seguir programas de orientación supervisados por el Ministerio de la mujer y poblaciones vulnerables.

(iii) Procurar, de ser el caso, reparar a la víctima (Hernández, 2012).

"Para que el proceso de menores pueda servir adecuadamente al interés del menor, debe construirse e interpretarse las normas que lo regulan considerando dos finalidades: (i) que el proceso no debe servir para estigmatizar al menor; (ii) que debe favorecer la reeducación del menor" (Álvarez Alarcón, 2004, p.305).

A su vez Juan Terradillos, expone lo siguiente: 
No cabe castigar cuando, a tenor de las circunstancias concurrentes en concreto, no resulte razonable exigir al sujeto una conducta distinta a la que realizó. Y no es exigible porque el derecho no puede esperar que nadie resista a una posición motivacional excepcional. La no exigibilidad deja, así, incólume la antijuridicidad, que va referida a comportamientos no deseados por el derecho. Este dirige su motivación normativa también a quien se mueve en una situación extrema (MIR), pero no considera adecuado castigarle si, en virtud de las circunstancias concurrentes, no adecúa su comportamiento a la norma." (Impulsado por un miedo insuperable) "Doble parámetro: el contexto situacional del sujeto y las circunstancias referidas a su personalidad, con todos sus conocimientos y condiciones personales, físicas, mentales...

(2004, p.38-39).

Es necesario reconocer que, en la mayoría de los casos, el contexto del menor infractor no es analizado, y se opta generalmente sin suficiente análisis por la medida socioeducativa internamiento. Si ello se cumpliría de modo adecuado, observaciones como la de Juan Terradillos no existirían, y mucho menos revestiría la importancia que mantiene.

En adición, Bravo Gamarra señala: "Para los mayores de 18 años no existen programas educativos especializados porque la intervención está prevista para adolescentes entre los 14 y 18 años, y la atención a jóvenes de 18 años a más requiere de objetivos, estrategias, metodologías específicas y diferentes. Los Centros Juveniles no cuentan con unidades educativas superiores que brinden calificación técnica o profesional” (Bravo, 2014, p.152).

Aquella observación permite identificar la falencia grave en la prevención del delito. Pues el menor infractor que sale del internamiento con las mismas aptitudes y regresa al medio que hizo propicia su conducta ilegal; será posible que reincida en la actividad criminal, pues no cuenta con los elementos ni herramientas necesarias para obtener de manera lícita, aquello que la sociedad a determinado como necesario e imperativo en sus metas culturalmente aceptadas (Merton, 1938).

Asimismo, el artículo 40 inciso 3 literal b) de la Convención sobre los Derechos del Niño determina lo la necesidad de medidas tales como la Remisión:

Artículo 40

3. Los Estados Partes tomarán todas las medidas apropiadas para promover el establecimiento de leyes, procedimientos, autoridades e instituciones específicos para los niños de quienes se alegue que han infringido las leyes penales o a quienes se acuse o declare culpables de haber infringido esas leyes, y en particular:

...b) Siempre que sea apropiado y deseable, la adopción de medidas para tratar a esos niños sin recurrir a procedimientos judiciales, en el entendimiento de que se respetarán plenamente los derechos humanos y las garantías legales.

(Naciones Unidas, 1989). 
Así también, la doctrina considera que “...los Estados deben limitar el uso del sistema de justicia juvenil y ofrecer alternativas a la judicialización de las causas." (Bravo, 2014, p.153). Todo ello en vista al Principio de excepcionalidad del sistema de justicia juvenil y al artículo 19 de la Convención Americana sobre Derechos Humanos (Derechos del niño: Todo niño tiene derecho a las medidas de protección que su condición de menor requiere por parte de su familia, de la sociedad y del Estado) (Pacto de San José, 1969).

En adición, las Directrices de las Naciones Unidas para la prevención de la delincuencia juvenil (Directrices de Riad), en sus Principios Fundamentales señalan que:

...5.- Deberá reconocerse la necesidad y la importancia de aplicar una política progresista de prevención de la delincuencia, así como de estudiar sistemáticamente y elaborar medidas pertinentes que eviten criminalizar y penalizar al niño por una conducta que no causa graves perjuicios a su desarrollo ni perjudica a los demás. La política y las medidas de esa índole deberán incluir:

a) La creación de oportunidades, en particular educativas, para atender a las diversas necesidades de los jóvenes y servir de marco de apoyo para velar por el desarrollo personal de todos los jóvenes, en particular de aquellos que están patentemente en peligro o en situación de riesgo social y necesitan cuidado y protección especiales;

b) La formulación de doctrinas y criterios especializados para la prevención de la delincuencia, basados en las leyes, los procesos, las instituciones, las instalaciones y una red de servicios, cuya finalidad sea reducir los motivos, la necesidad y las oportunidades de comisión de las infracciones o las condiciones que las propicien;

c) Una intervención oficial que se guíe por la justicia y la equidad, y cuya finalidad primordial sea velar por el interés general de los jóvenes;

d) La protección del bienestar, el desarrollo, los derechos y los intereses de todos los jóvenes;

e) El reconocimiento del hecho de que el comportamiento o la conducta de los jóvenes que no se ajustan a los valores y normas generales de la sociedad son con frecuencia parte del proceso de maduración y crecimiento y tienden a desaparecer espontáneamente en la mayoría de las personas cuando llegan a la edad adulta;

f) La conciencia de que, según la opinión predominante de los expertos, calificar a un joven de "extraviado", "delincuente" o "predelincuente" a menudo contribuye a que los jóvenes desarrollen pautas permanentes de comportamiento indeseable.

(Directrices de Riad, 1990).

\section{b) Características}

En Ginebra del 15 de enero al 2 de febrero del 2007, se realizó la Observación № 10 del Comité

de los Derechos del Niño. El punto 27 de dicha observación denominada "Los derechos del niño en la justicia de menores" acordó que:

...27. Queda a la discreción de los Estados Partes decidir la naturaleza y el contenido exactos de las medidas que deben adoptarse para tratar a los niños que tienen conflictos con la justicia sin recurrir a procedimientos judiciales, y adoptar las medidas legislativas y de otro tipo que sean 
precisas para su aplicación. Sin embargo, de acuerdo con la información contenida en los informes de los Estados Partes, es indudable que se han elaborado diversos programas basados en la comunidad, por ejemplo el servicio, la supervisión y la orientación comunitarios a cargo, por ejemplo, de asistentes sociales o de agentes de la libertad vigilada, conferencias de familia y otras formas de justicia restitutiva, en particular el resarcimiento y la indemnización de las víctimas. Otros Estados Partes deberían beneficiarse de estas experiencias. Por lo que respecta al pleno respeto de los derechos humanos y las garantías legales, el Comité se remite a las partes correspondientes del artículo 40 de la Convención y hace hincapié en lo siguiente:

- La remisión de casos (es decir, medidas para trata a los niños de quienes se alegue que han infringido las leyes penales o a quienes se acuse o declare culpables de haber infringido esas leyes sin recurrir a procedimientos judiciales) sólo deberá utilizarse cuando se disponga de pruebas fehacientes de que el niño ha cometido el delito del que se le acusa, de que ha admitido libre y voluntariamente su responsabilidad, de que no se ha ejercido intimidación o presión sobre él para obtener esa admisión y, por último, de que la admisión no se utilizará contra él en ningún procedimiento legal ulterior.

- El niño debe dar libre y voluntariamente su consentimiento por escrito a la remisión del caso, y el consentimiento deberá basarse en información adecuada y específica sobre la naturaleza, el contenido y la duración de la medida, y también sobre las consecuencias si no coopera en la ejecución de ésta. Con el fin de lograr una mayor participación de los padres, los Estados Partes también pueden considerar la posibilidad de exigir el consentimiento de los padres, en particular cuando el niño tenga menos de 16 años.

- La legislación debe contener indicaciones concretas de cuándo es posible la remisión de casos, y deberán regularse y revisarse las facultades de la policía, los fiscales y otros organismos para adoptar decisiones a este respecto, en particular para proteger al niño de toda discriminación.

- Debe darse al niño la oportunidad de recibir asesoramiento jurídico y de otro tipo apropiado acerca de la conveniencia e idoneidad de la remisión de su caso ofrecida por las autoridades competentes y sobre la posibilidad de revisión de la medida.

- La remisión efectiva de un niño deberá suponer el cierre definitivo del caso. Aunque podrá mantenerse un expediente confidencial de la remisión con fines administrativos y de examen, no deberá considerarse un "registro de antecedentes penales", y no deberá equipararse la remisión anterior de un caso a una condena. Si se inscribe este hecho en el registro, sólo deberá permitirse el acceso a esa información y por un período de tiempo limitado, por ejemplo, un año como máximo, a las autoridades competentes que se ocupan de los niños que tienen conflictos con la justicia.

(Observación general $\left.\mathrm{N}^{\circ} 10,2007\right)$.

Se resalta el último punto, que supone -en la aplicación de la Remisión- el cierre definitivo del caso, sin la formulación de antecedentes penales.

Además, Hernández Alarcón, determina que la Remisión mantiene 5 características principales:

a) Institución propia del Derecho Penal: El autor la califica como una oportunidad regulada. Establece que no se trata de una herramienta que posibilita la descongestión procesal, sino por el contrario, la Remisión tiene por fundamento realzar el interés superior del niño.

b) Punto de partida: última ratio y Principio de Subsidiariedad y Fragmentariedad Penal. Por lo tanto, la Remisión persigue la despenalización de conductas no graves, para que exista un tratamiento en la comunidad, lejos del etiquetamiento y estigmatización. Tal es así, que no es necesario determinar 
el envío del menor a cumplir con un programa social cuando se utilice esta herramienta de la Justicia Restaurativa.

c) Programas comunitarios óptimos: Educativos, de orientación y un programa especializado en la compensación y restitución de las víctimas.

d) Rol preventivo: Se considera que la intervención estatal debe ser progresiva, atenta a las causas de la conducta criminal, ya que de esa manera se reducen las oportunidades de reincidencia.

e) Decisión de adolescente infractor: La voluntad del menor no debe ser coaccionada, el consentimiento en la aceptación y aplicación de la Remisión debe ser libre y querida por el adolescente (2012, p.238).

En esencia, la Remisión se caracteriza por crear un estímulo positivo y disminuir la severidad y el castigo contraproducente. Se considera que dichos estímulos construyen conocimientos ya que reparan un daño, y de esa manera reconfortan a la víctima. La Remisión se convierte en una experiencia gratificante que envuelve un aprendizaje que enmienda errores y compensa positivamente a otros por los daños ocasionados.

\section{c) Requisitos generales}

La Remisión se encuentra definida en el Decreto Legislativo núm. 1348 (en adelante D.L. núm. 1348), en la Sección VI - Salidas alternativas al Proceso. Debe ser entendida como una institución que coincide con el siguiente ánimo “Artículo 127. - Definición: Son aquellas instituciones de resolución de conflictos, que buscan que las partes alcancen acuerdos evitando las consecuencias negativas que puede originar el proceso judicial para el adolescente. Deben ser incentivadas y propiciadas en todas las instancias del proceso.” (D. Leg.1348, art. 127).

Así también, aquella ley en el artículo núm. 128 brinda presupuestos generales de aplicación de alternativas más beneficiosas relacionadas a los conceptos desarrollados por la Justicia Restaurativa. Los cuales pueden ser utilizados, en cualquier momento del Proceso, por el Fiscal o el Juez.

Artículo 128. - Presupuestos de aplicación

Son presupuestos indispensables para la aplicación de la alternativa más beneficiosa para el adolescente, por parte del Fiscal o del Juez:

1. Contar con los respectivos informes de los Equipos Técnicos Interdisciplinarios, conforme se detallan en el presente Código.

2. La expresión clara y precisa de los alcances y efectos de la salida alternativa a aplicarse, así como de las obligaciones o condiciones que se vayan a imponer al adolescente. 
3. El asentimiento informado expreso del adolescente para la aplicación de cualquiera de las salidas alternativas que procedan en su caso, plasmado en un acta de compromiso firmada por el adolescente y sus padres, tutores o responsables.

4. La determinación del tiempo de duración de las mismas, que debe ser razonable y proporcional a la gravedad del hecho imputado.

5. Al elegirse las obligaciones y/o condiciones, se debe dar prioridad a aquellas que tengan relación con la naturaleza de la infracción que se imputa al adolescente, a fin de cumplir con la finalidad educativa y resocializadora del proceso de responsabilidad penal del adolescente.

6. La revocación de la salida alternativa por el incumplimiento de las obligaciones y/ o condiciones establecidas al adolescente, requiere apercibimiento previo y en su caso, una audiencia.

(D. Leg.1348, art. 128).

Es necesario también que la infracción cometida por el adolescente sea considerada de mínima gravedad. Cuando ello suceda, se aplicará un programa de orientación con enfoque restaurativo que no puede durar más de 12 meses (Art. 129 numeral 1 del D.Leg. núm. 1348) .El objetivo de dichos programas restaurativos es estimular y promover el desarrollo personal del menor; además resulta menester lograr la integración del delincuente con la comunidad (Art. 129 numeral 2 del D.Leg. núm. 1348).

Resulta esencial para el cumplimiento de los objetivos que mantiene la Justicia Restaurativa, el compromiso y la aceptación expresa del adolescente, sus padres o tutores responsables en la participación de los programas de orientación que se pudieran determinar (Art. 129 numeral 3 del D.L. núm. 1348). Este requisito es importante, toda vez que el menor debe entender que la conducta realizada es prohibida; mantiene esa naturaleza ya que ejecutar dicha acción desencadenaría un daño específico para una persona y un daño difuso en la sociedad a la que él pertenece y se desarrolla.

Es por ello, que también el legislador dispone, en los casos en los que corresponda, la reparación del objeto material sobre el cual recae el daño producto de la infracción penal (Art. 129 numeral 4 del D.L. núm. 1348).

\section{d) Requisitos específicos}

El legislador ha determinado dos aspectos específicos para determinar la viabilidad en la aplicación de la Remisión:

El primero exige que la infracción penal sea menor y que no amerite una medida socioeducativa de internamiento en un medio cerrado (Art. 130 numeral 1 del D.Leg. núm. 1348). De manera complementaria, la norma establece que será posible emplear la Remisión cuando el adolescente haya sido afectado gravemente, de manera física o psicológica, con el hecho que se le 
atribuye (Art. 130 numeral 2 del D.L. núm. 1348). No es necesario que ambos presupuestos se configuren para poder aplicar el alejamiento del sistema penal del menor infractor.

¿Qué es el alcance del calificativo grave para nuestro Operador de Justicia? El ordenamiento penal no ha determinado de manera taxativa aquello que es grave, por ese motivo debemos realizar una interpretación sistemática para unir dos preceptos penales: El art. 130 del D.Leg. núm. 1348 con el art. 162 del mismo ordenamiento. De esa manera es posible afirmar que una infracción penal reviste gravedad toda vez que, se establece el internamiento en medio cerrado para delitos dolosos que fijen una pena privativa de libertad no menor de 6 años, siempre que se haya colocado en grave riesgo a la vida, integridad física o psicológica del sujeto pasivo (según el artículo 162 inc. 1 del D.Leg. núm. 1348).

En consecuencia, no serán graves las conductas realizadas por menores que no hayan colocado en grave riesgo la vida, integridad física o psicológica de la víctima.

\section{3.- Remisión Fiscal y Judicial}

La Remisión Fiscal evita que empiece un proceso penal en contra del menor, aleja al adolescente infractor del sistema punitivo. En cambio, la Remisión Judicial persigue la separación o la culminación inmediata del proceso penal; además, con la determinación de la Remisión Judicial se acompañará una medida socioeducativa diferente a la medida de internamiento en medio cerrado. “... favorece su proceso de responsabilización durante la ejecución de la medida socioeducativa en libertad" (Hernández Alarcón, 2012, p.248). La imposición de la medida socioeducativa es la característica más relevante que diferencia la Remisión Judicial de la Remisión Fiscal.

En aquel contexto resulta menester imponer una medida socioeducativa cada vez que se realiza una Remisión Judicial, no obstante, es posible elegir y ponderar, de acuerdo a la gravedad de la conducta delictiva, una medida adecuada.

Habrá casos en los que la amonestación será suficiente respuesta y el caso deba ser archivado en el acto (recordemos aquellos supuestos en los que la no intervención hubiese sido la mejor respuesta); mientras que habría otros que ameritarán una medida socioeducativa distinta, sea de acompañamiento en libertad o de prestación de servicios a la comunidad.

(Hernández Alarcón, 2012, p.248). 
La oportunidad para solicitar la Remisión está limitada por los artículos 131, numerales 1, 2 y 3 del D.L. núm. 1348. El Fiscal podrá solicitarla durante las diligencias preliminares y durante la investigación preparatoria formalizada. Una vez formalizado el proceso, también podrá solicitar la Remisión al Juez de la Investigación Preparatoria. Para el Juez resulta obligatorio validar esta decisión en una audiencia donde concurran los sujetos legitimados. Así también, tanto el Fiscal como el Juez, deben de tener en cuenta el Informe Técnico Interdisciplinario del Ministerio Público (Art. 131 numeral 3 del D.Leg. núm. 1348).

En otro orden de ideas, cuando la Sala determine la separación del menor del sistema penal, no es posible afirmar que dicha acción constituya un acto de impunidad; toda vez que es posible aplicar cualquiera de las medidas socioeducativas al adolescente, con excepción del internamiento en medio cerrado.

Art. 132 numerales 7 y 8 del D.Leg. núm. 1348: 7. Luego de cumplida la remisión, el Equipo Interdisciplinario del Ministerio Público brinda al adolescente una asistencia, que le permita atender necesidades posibles al menos hasta los seis (06) meses siguientes. Asimismo, en tanto el adolescente lo autorice, realiza un seguimiento de las actividades desarrolladas por el adolescente tras culminar con la remisión. 8. En todos los casos, el Fiscal en la disposición que corresponda, precisa la duración de la remisión. “..., es fundamental efectuar siempre una ponderación y tomar una decisión que sea educativa para el propio infractor y le dé una respuesta actual a su vida, este es el caso de la remisión a nivel judicial" (Hernández Alarcón, 2012, p.248).

“...La reintegración social solo se alcanza por medio del mejoramiento y desarrollo de las capacidades de adecuación y convivencia del adolescente, tanto dentro de su familia como de su entorno social (cambio de actitudes), y del aprovisionamiento de reconocimientos y competencias como herramientas básicas para el desarrollo personal" (Hernández Alarcón, 2012, p.251).

Por tanto, el Fiscal tiene la obligación de proponer la remisión judicial como vía alternativa al proceso judicial "procura la solución alternativa al proceso del adolescente, en especial la remisión, mediación, conciliación y las prácticas restaurativas" (art. 14 lit. "q" del D.L. núm. 1348). Asimismo, el Juez tiene la potestad de aplicar la remisión judicial como salida alternativa del proceso (art. 9 del D.L. núm. 1348).

Es necesario mencionar que los artículos relativos a la institución de la Remisión determinados en el Código de los Niños y Adolescentes fueron derogados por el D.L. núm. 1348 
(Los Capítulos VI y VII de Remisión y Medidas Socioeducativas del Código de los Niños y Adolescentes en sus artículos del núm. 223 al 241).

No obstante, es posible hallar una similitud entre los artículos derogados del Código de los Niños y Adolescentes, con lo determinado por el Decreto Legislativo núm. 1348. Toda vez que la Remisión observaba también la gravedad del delito cometido, y en caso de no ser un hecho muy grave brindaba una alternativa diferente a la del internamiento dentro de un centro correccional (arts. DEROGADOS núm. 223, 224, 225, 226, 227 y 228 del Código de los Niños y Adolescentes). Uno de los problemas con el Código de los Niños y Adolescentes era que los artículos que definían a la Remisión no delimitaba la gravedad y tampoco definían qué se podía considerar como una acción que "no revista de gravedad". Un hurto en la noche, a un menor de 17 años, puede ser considerado como muy grave, o al menos medianamente grave, pese al carácter patrimonial del objeto material (de naturaleza restitutiva) y la falta de violencia. No existe una medida que determine con exactitud, ni que diferencie los grados de intensidad en la gravedad de las infracciones penales. Se espera que el Reglamento del Decreto Legislativo núm. 1348 establezca los límites que el legislador considera como una infracción típica que no revista de gravedad.

\section{4.- Utilización de la Remisión en la Justicia Juvenil}

Es necesario hacer referencia a la estadística elaborada por la Gerencia de los Centros Juveniles del Poder Judicial: 
Figura 7.1.

Medidas socioeducativas impuestas a los adolescentes en conflicto con la ley penal

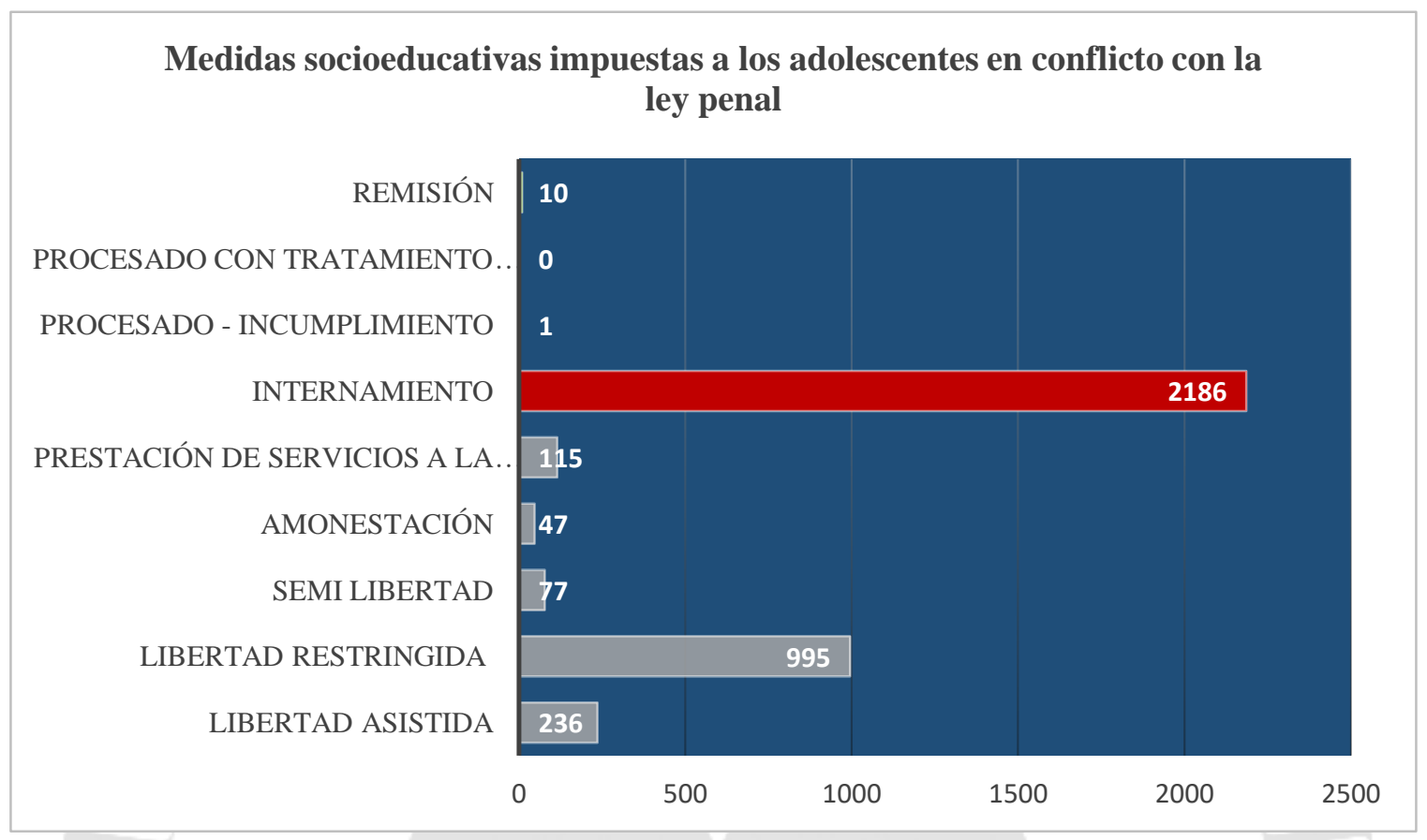

Fuente: Poder Judicial. Gerencia de Centros Juveniles. (2017). Tipo de medidas socioeducativas según sistema cerrado-sistema abierto. Informe estadístico 2017. Lima: Oficina de imagen institucional. Febrero 2017. Pág. 19.

Dicho cuadro evidencia que la Justicia Restaurativa destinada a favorecer a los menores en conflicto con la ley penal, no es empleada por los Operadores de Justicia.

De un universo de 3, 674 jóvenes infractores de la ley penal en febrero del año 2017, la Remisión benefició solo a 10 menores. Ello quiere decir que la utilización de la medida Remisión representa solo el $0.27 \%$ de la población total del universo. Por tanto, se puede afirmar que los Jueces y Fiscales del Perú no consideran relevante ni útil la medida de Justicia Restaurativa; toda vez que menos del $1 \%(0.27 \%)$ de los jóvenes infractores han podido obtener una medida socioeducativa diferente a la de internamiento en medio cerrado.

Es también posible considerar que todas (o casi todas, 99.73\%) las infracciones cometidas por los menores son entendidas por los Operadores de Justicia como infracciones que revisten mucha gravedad; ya que, si no fuera así, la Remisión sería más utilizada. Pues también se imponen medidas socioeducativas de internamiento a menores que cometieron infracciones sin violencia; así en los hurtos. 


\section{CAPÍTULO VIII: LÍMITES RACIONALES DE LA PROPUESTA}

\section{1.- Cesare Beccaria: Utilidad más Necesidad. No para todos}

Beccaria un joven que con 25 años escribió una de las mayores obras del Derecho Penal. De los delitos y las penas, rompe con el paradigma de la Santa Inquisición y las cortes reales para crear las bases necesarias que hoy empleamos para castigar aquellos actos que contravienen el pacto social. "Libres y aislados sobre el haz de la tierra, cansados de vivir en un estado de guerra continuo y fatigados por una libertad que venía a ser inútil por la incertidumbre de conservarla, sacrificaron los hombres una porción de ella para gozar la restante con paz y seguridad" (Beccaria, 1821, p.4).

Además de darle una óptica criminal a su estudio, la blindó con criterios económicos: aquellos determinados por la necesidad y utilidad. Para ello necesitó guiarse de los conceptos desarrollados por Rousseau; se apoyaba en la creencia de la cooperación y en la idea de Tabula rasa. Se explica, que el hombre en su estado natural es un ser sin maldad ni bondad, no conoce nada, es una pizarra en blanco, y será el medio en el que nace, aquel que determine sus conocimientos, principios, tradiciones y acciones. También se dice que el control/gobierno de estas sociedades estará limitado por la cooperación; una suma de virtudes que harán posible la vida en sociedad. El fin supremo de la sociedad es la supervivencia y la protección mutua, jamás la destrucción.

En ese sentido, Beccaria, recoge lo explicado por Rousseau, defiende su postura y reafirma que el fin supremo de la sociedad es la cooperación; sin embargo, ¿por qué eliminamos a las personas cuando las sentenciamos a muerte?, ¿por qué se dispone de la vida?, ¿por qué superponemos a la destrucción frente a la cooperación?

El ejercicio de la función punitiva tiene límites: el control del ejercicio del poder. (...) a) Límites en el nivel de la prohibición. Si los hombres se unieron en sociedad fue por la necesidad de superar un estado natural que les resulta nefasto y con miras a un estado de asociación civil mejor que el estado de antes. Por consiguiente: la limitación a la libertad debe ser la mínima posible: "Las penas que sobrepasan la necesidad de conservar el depósito de la salud pública, son por su naturaleza injustas. b) Límites en el nivel de la ampliación de la pena. Si el delito no es el pecado, si el delito no es un vicio, la pena no tiene por función la expiación; ella es un "motivo sensible" que solo tienen por misión "desviar el ánimo despótico de cada uno de los hombres de volver a sumergir en el antiguo caos las leyes de la sociedad". De este punto de partida, se deriva la crítica que hace el autor a las penas de su tiempo, las que se aplicaban con fin expiatorio.

(Beccaria, 2012, p.xxiii-xxiv). 
Para responder estas preguntas, utiliza dos principios básicos: El principio de proporcionalidad y el principio de indisponibilidad. Ambos, pilares del trabajo de Beccaria, bajo la óptica de la necesidad y la utilidad. “(...) la Declaración de 1789 ya estableció que las leyes no deben prever "más que penas estricta y evidentemente necesarias" (art. 8), la de 1793 especifica "que las penas deben ser proporcionadas al delito y útiles a la sociedad" (art. 15)" (Pietro Sanchís, 2007, p.51).

Aquí el primer principio (a modo de ejemplo) cuando se afecte, o el daño se produzca sobre el bien jurídico patrimonio, la solución es resarcir el daño, sustituyendo el bien dañado por otro de las mismas características.

Hoy, este autor afirmaría que, si el "sujeto A" hurta un teléfono celular al "sujeto B", el "sujeto A" debe trabajar para resarcir el daño, sustituir el bien por uno nuevo y mitigar en alguna medida la conducta delictiva; el agente jurisdiccional no lo castigaría a una pena privativa de la libertad. Pero, este principio no se puede aplicar para todos los delitos, pues existen algunos que afectan a bienes jurídicos intangibles o de carácter fundamental.

Por ejemplo, en caso de mutilación del cuerpo. No existe una manera de resarcir el daño de manera proporcional. En estos casos, según Beccaria es necesario utilizar un espacio en el que se separe al sujeto causante del daño, todo ello con el propósito de enseñarle lo nocivo de su acto, la pérdida de la víctima, los efectos sociales y económicos que implican en la sociedad el daño de un derecho fundamental. Algo que jamás volverá a ser igual; será irrecuperable.

Para este último ejemplo, Beccaria explica que es necesario utilizar ese espacio denominado prisión, (que hasta ese momento -siglo XVIII- solo era utilizado como un tiempo de transición; entre la denuncia y el suplicio o la horca), para enseñar. En el sentido utilitario, define que la sociedad se encuentra en riesgo, pues el sujeto criminal puede causar daños de gran magnitud también a otras personas. Para reducir el peligro y evitar el daño que posiblemente se produzca, se considera útil encerrar a personas. Recordemos, todo con el propósito final en ese planteamiento es el de enseñar y educar. "Nadie puede transferir a otro un poder superior al que él mismo posee, y nadie posee poder arbitrario absoluto sobre sí mismo, ni sobre otra persona; nadie tiene poder para destruir su propia vida ni para arrebatar a otra persona la vida o las propiedades" (Locke, 1987, pp.101-102). 
Del mismo modo, sigue el principio de indisponibilidad, el único creador de la vida es Dios, a nadie más se le puede atribuir la creación del cuerpo. En consecuencia, solo él puede disponer de este elemento. Afirma que no podemos dotar de un poder inmenso y desproporcionado a las personas, de sobre manera, cuando todo ello posee una finalidad destructiva; la vida no es bien sobre el cual se pueda deliberar. Recordemos, el fin de la sociedad es la cooperación de virtudes con el objetivo de conseguir beneficios; jamás apelar a la destrucción de la humanidad (Pietro Sanchís, 2007).

Muchas de las personas en prisión son delincuentes menores que han cometido ofensas menores contra el orden público. Ciertamente, sus ofensas no pueden ser ignoradas, en especial si son persistentes y constituyen una molestia pública. Para estos casos es necesario disponer algunas restricciones a su libertad y ciertas formas de supervisión, pero ¿necesitan realmente estas personas que se las mantenga en prisiones o en colonias rodeadas de vallas de tres y cuatro metros de alto, resguardadas por personal armado y perros, en localidades aisladas, muchas veces con poco para mantenerlas ocupadas? Cuando esto pasa, existe un verdadero peligro de que salgan de la prisión en peores condiciones de las que entraron; de que estén, probablemente, mejor preparadas para cometer delitos más graves después de su liberación. En su lugar, deberían hacerse los arreglos para tener sobre estas personas alguna forma de supervisión y control en la comunidad, o al menos mantenerlas en condiciones de mínima seguridad. La experiencia en muchos países no ha mostrado que una gran cantidad de las personas que están en prisión tienen desórdenes mentales; una investigación publicada hace algunos años sugirió que hasta un $25 \%$ de los presos en Inglaterra sufren de ese tipo de desórdenes. La verdad es que las personas que están enfermas mentalmente no deberían enfrentarse con el sistema de justicia penal. Y mucho menos estar en prisión; deberían estar bajo el cuidado del sistema de salud. Es cierto que un pequeño número de ellas pueden representar una amenaza pública; aun en ese caso deberían ser cuidadas por autoridades de salud en un alojamiento seguro. Los mismos principios aplican para los hombres y mujeres que abusan de las drogas y del alcohol. En una palabra, la prisión no debería usarse como un bote de basura para retener las víctimas de la sociedad: aquellos que están desempleados, que no tienen una casa, que no tiene una familia y cuya presencia en nuestro medio es una inconveniencia para el resto de nosotros. Todas estas consideraciones aplican, incluso en un mayor nivel, cuando las personas que están bajo custodia son mujeres y jóvenes; para ellos, en particular, la prisión debería ser un lugar utilizado únicamente cuando no hubiera otra alternativa.

(Coyle, 2001, p.107).

De acuerdo a los conceptos brindados por Beccaria para limitar este recurso, es nocivo mantener a alguien en un Centro Juvenil, que no reúna los requisitos mínimos de rehabilitación (por las condiciones de hacinamiento, violencia e incapacidad administrativa). Y por ello, si algunos de los infractores no violentos logran sin violencia materializar su instinto de recuperación de la libertad, entonces será más beneficioso que se resocialicen en libertad. Sin embargo, se recapturará sin violencia a aquellos jóvenes que afectaron bienes jurídicos irreparables y fundamentales. 
El llamado estado de necesidad supralegal contiene el principio de la ponderación de bienes y el de la autonomía. Es decir, justicia la defensa del bien jurídico más valioso o más fuertemente puesto en peligro en aquella situación. Pero con este principio se cruza la garantía de la autonomía de la personalidad, que prohíbe, por ejemplo, que alguien sea castrado coactivamente en bien de la comunidad o que, en contra de su voluntad, se le extirpe un riñón para trasplantarlo.

(Roxin, 2000, p.79).

Por ejemplo, si un menor cumple una medida socio educativa de internamiento en medio cerrado por afectar el bien jurídico patrimonio y, cumpliendo su medida logra fugar, entonces se recomienda revisar los elementos establecidos en la Remisión, para alejar de manera eficaz al joven infractor del sistema formal de control social. Ello incluirá la posibilidad de no recapturarlo, y en caso que se le recapture, se pueda aplicar de manera obligatoria una evaluación para implementar el mecanismo de justicia restaurativa en el caso específico; ello brindará la posibilidad de reparar el daño, reintegrar a la víctima y al infractor en la sociedad sin tener que afrontar el proceso de etiquetamiento y estigmatización del Proceso Penal.

Figura 8.1.

Fuga: Supuesto de atención

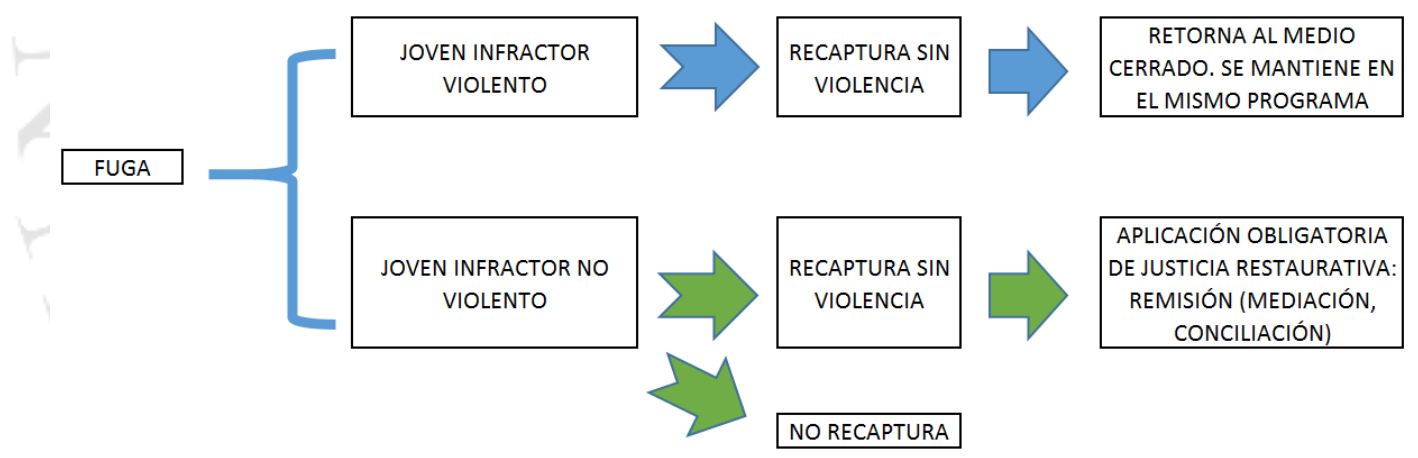

Nota: Elaboración propia. Esquema de propuesta.

Asimismo, el análisis de Roxin también cuestiona la necesidad del castigo y el objeto del mismo:

La tercera de nuestras categorías sistemáticas fundamentales - la culpabilidad- viene acuñada desde el punto de vista político-criminal por la teoría de los fines de la pena. Si se comprueba, en efecto, que el actuar del autor era erróneo desde el punto de vista de la regulación social de conflictos, queda todavía por responder para la labor dogmática la ulterior cuestión de si una tal conducta merece una pena. Con esta cuestión tiene que ver todo, lo que acostumbra a tratarse bajo el punto de vista de la culpabilidad. Para empezar con lo más simple: si alguien, por las razones que sean, no puede evitar el injusto típico por él realizado, carece de objeto castigarlo; (...).

(2000, p.89). 
Aplicar el nuevo supuesto de Remisión a un menor que obedece a su instinto de búsqueda de la libertad y que a su vez no ha cometido una infracción que atente contra esas tres garantías mínimas (vida, cuerpo, libertad) merece la aplicación de la Remisión que representa una oportunidad, una alternativa que aleja al infractor del Sistema Penal, de la vida delictiva y evita la convivencia con lo más peligroso y nocivo de nuestro medio. "La libertad únicamente se convierte en positiva a través del uso que de ella hacemos. No nos asegura oportunidades especiales, pero deja a nuestro arbitrio decidir el uso que haremos de las circunstancias en que nos encontremos" (Hayek, 2014, p.43).

Unos delitos destruyen inmediatamente la sociedad, o a quien la representa; otros ofenden la seguridad particular de un ciudadano en su vida, en sus bienes o en su honor; otros son acciones contrarias a lo que cada cual está obligado a hacer o no hacer con miras al bien público. Cualquier acción no comprendida entre los dos entredichos límites, no puede llamarse delito, o ser castigados como tal, sino por quienes encuentran su interés en llamarla así.

(Beccaria, 2012, p.61).

En gran medida lo que Beccaria buscaba en aquel siglo era una justicia restaurativa, en este trabajo se exponen sus ideas y hace promoción al Plan Nacional de Prevención y Tratamiento del Adolescente en Conflicto con la Ley Penal. Que es compatible con los criterios de Beccaria y las orientaciones de Roxin. Este plan apela a evitar la utilización de sanciones que priven la libertad y coloca el centro de atención en la prevención criminal. Lo que este plan propone como justicia restaurativa, al respecto: “(...), compuesta por las siguientes dimensiones: a) Orientación diferenciada con mayor probabilidad de reinserción para el adolescente, b) Restauración del daño a la víctima y a su familia, c) Restauración de la perturbación social ocasionada con miras a la participación de instituciones públicas y privadas bajo un enfoque restaurativo" (Consejo Nacional de Política Criminal, 2014, p.28).

Es decir, que los menores que cometan actos contra el patrimonio tengan la oportunidad de devolver lo que ilícitamente consiguieron, restituir el bien y así mitigar o eliminar el daño causado. En suma, esta justicia reparadora o restaurativa debería ser utilizada como el primer recurso en contra de las conductas típicas (para aquellos que no causaron mayores daños o atacaron bienes jurídicos diferentes), colocar a menores en un espacio hacinado reduce la posibilidad de resocialización; un trabajo por el contrario genera disciplina, dinero y felicidad. 
El penitenciarismo debe retornar, en mi opinión, con un rostro humano, orientado por el conductismo y con miras a atemperar el encono social que ha hubiera producido el fenómeno. No es la hora de endurecer el sistema, sino de transformarlo hacia una omnicomprensión del fenómeno. Es una paradoja, pero es cierta y necesaria si es que la sociedad, en un esfuerzo desesperado, quiere reencauzar las instituciones públicas como un medio para alcanzar su seguridad.

(Maldonado Manzanilla, 2010, p.83).

\section{2.- Supuesto adicional de Remisión por fuga no violenta}

La propuesta central de esta tesis se concentra en atender un supuesto adicional en la aplicación de la Remisión. Tanto que, el propósito que la Remisión es alejar al menor del sistema penal (medio nocivo que implica el encierro del adolescente). El legislador no desea insertar en un medio cerrado a una persona que no haya cometido infracciones graves. En consecuencia, el nuevo supuesto de Remisión permite que el adolescente no violento, que no cometió una infracción que revista gravedad y que -influido por su instinto de recuperación de libertad- escape sin violencia del medio cerrado, también pueda ser evaluado en los mismos preceptos y condiciones que mantiene la remisión para determinar si es necesario alejar del sistema penal al adolescente fugado sin violencia.

Los preceptos rectores son los mismos (evitar estigmatización, infracción no grave, rehabilitación en comunidad) el único elemento que adiciona este nuevo supuesto de la remisión es la fuga no violenta realizada por el adolescente interno. Es decir, será posible evaluar la condición del menor, en caso éste se evada de un Centro Juvenil de Diagnóstico y Rehabilitación; en aquel contexto, se debe considerar nuevamente las finalidades y requisitos de la remisión. Ya que de esa manera, con una nueva evaluación, el fugado pueda ser separado de manera inmediata del sistema penal y cumplir con los fines de la justicia restaurativa.

Todo ello, en atención a que no es una conducta delictiva escapar de un medio cerrado, es más bien, una conducta entendida desde la naturaleza humana y que toda persona que se encuentre sometida a un encierro anhelará recuperar la libertad. Este deseo de escape se ve acrecentado por el castigo desatento y desproporcionado del Operador de Justicia que no empleó la Remisión a su debido tiempo y oportunidad.

No hay que llevar a los hombres por las vías extremas; hay que valerse de los medios que nos da la naturaleza para conducirlos. Si examinamos la causa de todos los relajamientos, veremos que proceden siempre de la impunidad, no de la moderación de los castigos. Secundemos a la naturaleza, que para algo les ha dado a los hombres la vergüenza; hagamos que la parte más dura de la pena sea la infamia sufrida. 
(Montesquieu, 1999, p.58).

Figura 8.2.

Esquema comparativo entre la Remisión y el nuevo supuesto de Remisión propuesto

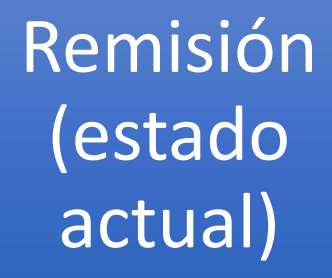

Nuevo

Supuesto de Remisión
- Evita estigmatización, etiqueta.

-Infracción que no reviste gravedad.

- Separa al menor del medio nocivo en caso de fuga no violenta.

- Rehabilitación en comunidad.

Nota: Elaboración Propia.

La exclusión del clima hostil, que representa esta nueva hipótesis de remisión, mantiene solo una característica adicional: Fuga no violenta realizada por un adolescente que se encontraba interno por cometer una infracción considerada como no grave. Es posible reforzar a la Remisión con esta nueva característica ya que incluye (aparte de cumplir con todos los presupuestos dados en la norma D.L. núm. 1348) una conducta de escape no violento, generada por el instinto humano como respuesta al encierro en un lugar estigmatizador, con abusos de poder; medio en el que la Sociedad justifica que el adolescente infractor merece toda clase de castigos por su sola condición de interno de un Centro Juvenil de Diagnóstico y Rehabilitación.

En cierta medida esta nueva remisión acepta que tanto el Fiscal como el Operario de la ley penal (Juez) puedan reevaluar la aplicación de la Remisión del adolescente del sistema penal. Es una nueva oportunidad, que deberá servir para observar y cumplir con los requisitos y obligaciones que determina la Remisión, ya que de esa manera (según se cumplan satisfactoriamente los supuestos que el Decreto Legislativo núm. 1348) sería posible separar del Sistema Penal al menor no peligroso fugado sin violencia de un Centro Juvenil de Diagnóstico y Rehabilitación. 
No obstante, la falta en la especificación del D.L. núm. 1348 sobre lo que el Legislador entiende por gravedad, nos lleva a concluir que este criterio se debe establecer por la naturaleza de la acción (violencia, o falta de ella) ${ }^{29}$ y en función al bien jurídico protegido afectado (Ministerio Público, s.f.). La medida socioeducativa que impone el internamiento del adolescente no puede disponerse sin atender el carácter de Necesidad y Utilidad (conceptos desarrollados en el numeral anterior de este trabajo).

Ni la venganza de la ofensa hecha a la sociedad, ni la expiación del delito son los objetos de las penas. La venganza es una pasión, y las leyes están exentas de ella (...). El objeto pues de las leyes, cuando castigan los delitos, no puede ser sino impedir que el delincuente haga otros daños a la sociedad, y retraer a los demás de imitar su ejemplo, por medio de la impresión que debe causar en sus ánimos la pena que él padece: y si se puede conseguir este fin con las penas más suaves, no deben emplearse las más severas (...). Si no se contiene en estos límites, cae en la tiranía $(\ldots)^{30}$.

(Filangieri, 1823, pp.323-324).

Finalmente, se toman en consideración tres artículos del D.Leg. núm. 1348 (2017) que refuerzan las justificaciones antes dadas. En primer lugar:

Artículo núm. 6.-Excepcionalidad de la Privación de libertad: La privación de libertad del adolescente, aun cuando sea preventiva, tiene carácter excepcional y debe estar debidamente fundada, es aplicada como medida de último recurso. La fundamentación de la medida debe señalar el motivo por el cual no es posible aplicar una medida alternativa. La duración de la privación de libertad debe ser la más breve posible.

Aquel artículo refuerza el carácter de última ratio de la norma penal, y se establece la obligación de fundamentar la decisión que priva la libertad a un adolescente. No obstante, y pese a la aparente postura garante y preventiva del Legislador, el Decreto Legislativo núm. 1348 mantiene el máximo de 10 años como medida de internamiento para aquellos delitos que afectaron bienes jurídicos fundamentales ${ }^{31}$. En ciertos artículos, el Legislador demuestra el ánimo

\footnotetext{
${ }^{29} \mathrm{Al}$ respecto el Ministerio Público define lo siguiente: "VII.- REMISION.- 1.Procede aplicar la remisión en los casos de comisión de infracciones a ley penal graves. La ley señala que no procede, pero no explica cuales son graves. 2.¿Cuál es el criterio para diferenciar cuales son infracciones graves? Las circunstancias del hecho, la afectación del bien jurídico, la afectación a la víctima, la prueba existente."

${ }^{30}$ ¿Estos "beneficios" y recursos presentes en la Remisión generan impunidad, incentivan actividades delictivas o tienen un efecto psicológico perjudicial para la administración de justicia? Creemos estas iniciativas se fundamentan en la intención de maximizar beneficios. Verbigracia, el propósito de la prescripción penal, es eliminar la eterna persecución, encontrar el perdón otorgado por el tiempo. Es también una oportunidad.

${ }^{31}$ Decreto Legislativo núm. 1348. Artículo163.4 Excepcionalmente, cuando se trate del delito de sicariato (108-C) o violación sexual de menor de edad seguida de muerte o lesión grave (173-A), así como de los delitos regulados mediante Decreto Ley $\mathrm{N}^{\circ} 25475$, la medida de internación puede durar de seis (06) a ocho (08) años, si el adolescente
} 
preventivo, sin embargo, la intención de castigar de manera dura con medidas socioeducativas cada vez más largas, es evidente.

Artículo 19.- 6. A ser ubicado en un ambiente adecuado y distinto al de los adultos, durante su detención en una dependencia policial y durante su conducción a la misma. En caso de adolescentes infractoras de la ley penal su ubicación es diferenciada del resto de adolescentes infractores, teniendo en cuenta un enfoque de género.

8. A que la privación de libertad sea una medida de aplicación excepcional de último recurso y deba durar el período más breve posible.

(Decreto Legislativo $\mathrm{N}^{\circ} 1348,2017$ ).

Para el año 2017, el Poder Judicial consideró como adecuado nombrar como Gerente de Centros Juveniles al Lic. Julio Magán Zevallos de larga experiencia con delincuentes de responsabilidad penal plena (ex Jefe del Instituto Nacional Penitenciario - INPE) (La República, 2016). La norma solicita una distinción en los ambientes y en el trato que se debe brindar a los menores infractores, no obstante la administración determinó para su Gerencia una lógica inversa.

Artículo 34 - Disposiciones generales: 34.2 Las medidas restrictivas de libertad personal tienen carácter excepcional, como último recurso y por el menor tiempo posible. La restricción de un derecho fundamental requiere expresa autorización legal, y se impone con respeto al principio de proporcionalidad y siempre que existan suficientes elementos de convicción.

(Decreto Legislativo $\mathrm{N}^{\circ} 1348,2017$ ).

La medida de internamiento supone excepcionalidad, sin embargo, la sobrepoblación en los Centros Juveniles demuestra que existe un ánimo distinto en los Operadores de Justicia. Por ello resulta menester promover y difundir la Remisión, para que se mitiguen los errores en la Administración y se pueda dar una Justicia Restaurativa integral, donde el delincuente infractor tenga la oportunidad de rehabilitarse en comunidad, de reparar el daño causado y no ser etiquetado ni estigmatizado.

En ese sentido, la fuga no violenta debe estar incluida en la lege lata, (escrita e integrada en el Cuerpo Jurídico del D.Leg. 1348, Código de Responsabilidad Penal de Adolescentes en el artículo núm. 130 -Supuestos de aplicación-). El nuevo supuesto de remisión debe ser expreso para que los Operadores de Justicia apliquen tal institución, motivando su decisión y cumpliendo su finalidad. La fórmula que se propone tiene el sentido siguiente: Artículo 130. Supuestos de

tiene entre catorce (14) y menos de dieciséis (16) años y de ocho (08) a diez (10) años, si el adolescente tiene entre dieciséis (16) y menos de dieciocho (18) años de edad. 
aplicación. La remisión se aplica cuando se cumpla alguno de los siguientes presupuestos: 3.Cuando el adolescente se haya evadido sin violencia del medio cerrado y cuando el hecho atribuido, motivo de su internamiento, se trate de una infracción a la ley penal que no revista gravedad.

\section{3.- Fundamentos del nuevo supuesto de remisión}

La evaluación ante una fuga sin violencia de un Centro Juvenil de Diagnóstico y Rehabilitación realizada por un adolescente que cometió una infracción que no reviste de gravedad, es en esencia el espíritu del nuevo supuesto de remisión. Es una respuesta eficiente para el contexto en el que se encuentra nuestro sistema de resocialización. Ofrece además una salida adecuada frente al contexto de hacinamiento de dichos Centros Juveniles.

Una salida oportuna ocasionada por una fuga, representa tres beneficios:

1. Acepta y reconoce un efecto inherente al encierro: la búsqueda constante de libertad,

2. Brinda a la comunidad la capacidad de eliminar la posibilidad de que el criminal adolescente obtenga mayor experiencia e información respecto a variados crímenes, y finalmente,

3. Ofrece una oportunidad para que los jóvenes infractores tengan mayor probabilidad de reinsertarse a la sociedad.

El Derecho es una ciencia que se encuentra en constante evolución, reconoce y admite los

límites de nuestro albedrío, nos limita y libera; se complementa con otras ciencias como la biología, la psicología, la economía, la historia, la criminología, etc. En ese sentido, una teoría en cualquiera de estas disciplinas significa para el Derecho, una adaptación.

Este nuevo supuesto de remisión se orienta en la idea comentada por Pietro Sanchís: “(...), incluso en algunos autores aparece una apelación a la dignidad del reo: "pues no es sólo que las sanciones suaves resultan de por sí menos nocivas, sino que, además, apartan al hombre del delito de la manera más acorde con su dignidad” (Von Humbolt. Los límites de la acción del Estado, citado, p. 151). En suma, que la pena “económica”, como la llamaba Bentham, será una nueva reivindicación llevada desde la filosofía ilustrada a la práctica política: "las leyes penales deben ser proporcionadas a los delitos, dulces antes que rigurosas” (Pietro Sanchís, 2007, p.53). 
Es posible deducir de la norma que ha determinado las finalidades, características y requisitos de la Remisión, promueve que la rehabilitación del adolescente infractor sea realizada en sociedad (a cargo de la comunidad). Ello implica una oportunidad, en tanto desaparecería el efecto estigmatizador que conlleva todo medio que priva la libertad. "Precisamente la libertad es tan importante, porque no sabemos cómo la utilizarán los individuos" (Hayek, 2014, pp.58-59). En ese sentido, lo determinado por Hayek, indica que la libertad de los individuos representa, en todo momento y circunstancia, también una oportunidad. Ella, no puede ser negada ni disminuida. Por tanto, este recurso penitenciario se alinea con los ideales de Hayeck, promueve la libertad y quiere para el menor-siempre que no haya dañado gravemente a la sociedad-las mejores opciones de vida y bienestar.

La transición del concepto de libertad individual al de la libertad como poder ha sido favorecida por la tradición filosófica, que al definir la libertad usa una palabra "limitación" donde nosotros hemos usado "coacción". Quizás "limitación" fuese la palabra más conveniente si se recordase siempre que en su estricto sentido presupone la acción de un agente humano que prohíbe. Utilizada en tal sentido, nos recuerda con mucha propiedad que infligir la libertad consiste principalmente en impedir que los hombres obren, mientras que la coacción entraña principalmente el obligarles a obrar en un sentido determinado. Ambos aspectos son igualmente importantes, y, para precisar, probablemente definiríamos la libertad como ausencia de limitación y coacción.

(Hayek, 2014, pp.39-40).

Asimismo, este nuevo supuesto de Remisión busca impedir el efecto "puerta giratoria", 32 , pues si bien los adolescentes en conflicto con la ley penal no tendrán antecedentes penales, es probable que reincidan en la actividad delictiva (McNeill, Farrall, Maruna, 2012). En ese sentido, Foucault utiliza la palabra "pasaporte" para referirse a los antecedentes penales, emplea el término pues explica que cada persona recluida que logra la libertad será siempre identificada con un nuevo pasaporte, este documento evidencia su estadía en el mundo criminal. Conseguir un trabajo no será fácil y volver a caer en las actividades ilícitas siempre será una opción. Toda vez, que en aquel tipo de actividades no se le requerirán antecedentes policiales ni penales.

Cabe agregar, que Foucault explicó además que existe una gran posibilidad de que estas personas reingresen a las cárceles, ya que encontrar trabajo, después de enseñar el "nuevo pasaporte", significa una tarea perdida que no vale la pena, a veces, intentar. Por tanto, una pena

\footnotetext{
${ }^{32}$ Fenómeno por el cual, las personas que entran al medio cerrado se convierten en "ciudadanos de segunda clase" etiquetados y marginales. En Aquel contexto, cuando su medida de internamiento termina, el grupo mayoritario vuelve a reincidir. De esa manera el medio cerrado se convierte en una constante, llena de reingresos; en aquel contexto es muy difícil reintegrarse a la sociedad.
} 
privativa de libertad dificulta, y en la mayoría de los casos, impide que los hombres obren con eficacia; arrojarlos a un mundo de reincidencias comienza en las medidas socio educativas, pues es el contacto ideal con el mundo criminal, sin barreras en lo que diferenciación de la infracción penal cometida.

En el Perú la aplicación de las medidas socioeducativas resulta la salida más práctica, mecánica o automática de nuestros Operadores de Judiciales, prueba de ello el hacinamiento generalizado con infracciones no graves. El concepto de "última ratio" fue olvidado y pese a tener márgenes de altos de hacinamiento se cree que enviar a un criminal menor a un centro donde priven su libertad ambulatoria sea la respuesta más adecuada y eficiente. “...las leyes penales no pueden perseguir más que tres objetivos: la enmienda del delincuente, el resarcimiento de la víctima y el interés de la sociedad. Por lo que se refiere al primero, resulta obvio que no es quitando la vida al culpable como se le puede corregir y hacer mejor” (Pietro Sanchís, 2007, p.156).

La pederastia, tan severamente castigada por las leyes, y tan fácilmente sometida a los tormentos vencedores de la inocencia, se funda menos en las necesidades del hombre aislado y libre, que en las pasiones del hombre sociable y esclavo. Toma su fuerza, no tanto de la saciedad de los placeres, como de aquella educación que comienza por hacer a los hombres inútiles para sí mismos, a fin de hacerlos útiles a los demás; en aquellas casas donde se congrega la ardiente juventud, donde habiendo un dique infranqueable a todo otro comercio, todo el vigor de la naturaleza que se desarrolla se consume inútilmente para la humanidad, hasta anticipa su senectud. El infanticidio es igualmente el efecto de una inevitable contradicción en que se ve puesta una persona que por debilidad o por violencia ha cedido. Quien se halla entre la infamia y la muerte de un ser incapaz de sentir los males, ¿cómo no habrá de preferir ésta a la miseria infalible a que quedarían impuestos ella y el fruto infeliz? La mejor manera de prevenir este delito sería proteger con leyes eficaces la debilidad contra la tiranía, la cual exagera los vicios que no se pueden cubrir con el manto de la virtud. No pretendo disminuir el justo horror que merecen tales delitos; pero al indicar sus fuentes, me creo con derecho a sacar una consecuencia general, que es: no se puede llamar precisamente justa (lo cual quiere decir necesaria) la pena de un delito, mientras la ley no haya empleado el mejor medio posible, en las circunstancias dadas de una nación, para prevenirlo.

(Beccaria, 2012, p.80).

Lo definido en el siglo XVIII por Cesare Beccaria, respecto al sistema penal en aquel momento, estaba regido por las consecuencias de los actos criminales, en el mundo caótico que esto representa, los daños, la violencia, el miedo. Con frecuencia se olvida que la mejor manera de contrarrestar estos problemas se encuentra en las medidas preventivas. Es menester preguntar qué ocasiona el crimen, por qué las personas cometen actos criminales y la respuesta que se genere arrojará como uno de los principales motivos a la imposición de las penas privativas de libertad 
(incluidas también medidas socio-educativas que determinen el internamiento del menor en un medio cerrado).

Se observa que existen medidas influenciadas por la Justicia Restaurativa en nuestro sistema normativo (como la Remisión); no obstante, como líneas arriba se evidenció, son poco utilizados. En adición, es notoria la posición de los Operadores de Justicia que se resisten considerar las consecuencias que conlleva encerrar - en condiciones de hacinamiento- a menores que cometieron infracciones no graves en un espacio que no los separa por infracción cometida. La tupida celosía en la que se desarrolla el sistema de justicia dificulta su tarea, observar el problema con claridad es un reto y el legislador, empujado por la opinión pública derivada a veces por la prensa no objetiva, solo incrementa el riesgo para las víctimas.

(...) el proceso de secularización del Derecho y de la Filosofía Penal está en la base, o al menos, representa un estímulo para la tesis que concibe la desviación criminal, no como la expresión de una enfermedad moral, sino como la consecuencia de una mala organización de la sociedad y que, por tanto, resulta más eficaz y razonable poner remedio a sus causas que hacer uso de la fuerza; en otras palabras, que el Código Penal, el más cruel de los instrumentos estatales, no es el único ni seguramente el más adecuado modo de combatir la delincuencia, que muchas veces no llegaría a exteriorizarse con una adecuada prevención; así, en lugar de condenar a muerte a la mujer infanticida que deja morir al hijo para ocultar su deshonra, valdría más crear hospitales donde pudiera dar a luz secretamente

(Voltaire, s.f., p.88).

Verbigracia, el mes de diciembre del año 2015, el gobierno de los Estados Unidos de Norteamérica, alentado por la Criminología, incluyó una medida de prevención del crimen basada en atenuar el nivel de encarcelamiento. Esta medida logró la reducción del porcentaje en la población de las cárceles de Estados Unidos por 7 años seguidos (2007-2014) (U.S. Department of Justice, 2014). Se observó que el incremento en la dureza en las penas y la efectividad de las mismas mantenía un efecto contrario al deseado, el crimen no disminuía; no funcionó el castigo desmesurado (Humphreys, 2015) y aquel país seguía con el mayor número de encarcelados (The National Academies Press, 2014, p.36). "Un argumento, sugerido por Beccaria y desarrollado por Kant: que el hombre debe ser considerado siempre como un fin en sí mismo y nunca como un medio para alcanzar otros fines" (Pietro Sanchís, 2007, p.57).

Creemos firmemente que los castigos severos y las penas efectivas no representan la solución para combatir nuestro índice de criminalidad o sistema de seguridad; tiene el efecto contrario, lo especializa y difunde. 


\section{4.- Requisitos para la implementación del nuevo supuesto de Remisión}

Es posible afirmar que será necesaria la recaptura y el re-encierro del menor que fugue del Centro Juvenil, siempre y cuando, de manera simultánea se cumplan ciertos requisitos. El principal, es pese a la evasión: que la infracción no revista gravedad y luego, la ausencia de violencia en la fuga, ya que ella asegura que la acción no concuase con un determinado tipo penal. No es necesario abundar con aquellas fugas que implican violencia y daños a otros bienes jurídicos protegidos, ya que estas nuevas acciones son perseguidas por un Fiscal en un nuevo proceso penal, con posibles implicancias de una nueva medida socio-educativa o condena, dependiendo de la edad del menor.

Es decir, para efectivizar los requisitos de la esta nueva forma remisión es necesario que confluyan elementos dados que permitan la tutela efectiva y disminución de factores de riesgo en el menor que fuga sin violencia del medio cerrado. En primera instancia el menor debe tener un padre o tutor al cual acudir, así también, el adolescente fugado no debe estar cumpliendo una medida socio-educativa por cometer una infracción que revista gravedad. Además, la fuga no debe implicar la comisión de un nuevo delito/infracción. Estos tres elementos configuran el límite para la aplicación de la recaptura, y en conjunto, incentivan una evaluación, oportunidad y disminución del factor de riesgo que puede convertirse un Centro Juvenil con hacinamiento, pocos educadores y ausencia de patios diferenciadores en algunos programas. El siguiente cuadro explica la propuesta de la reacción estatal que se propone sobre el retorno al medio cerrado: 


\section{Tabla 8.1}

Requisitos para no retornar al medio cerrado

\begin{tabular}{|c|c|c|c|c|c|c|c|c|c|}
\hline & $\begin{array}{l}\text { INFRACCIÓN } \\
\text { COMETIDA }\end{array}$ & $\begin{array}{c}\text { BIEN } \\
\text { JURIDICO } \\
\text { PROTEGIDO }\end{array}$ & FUGA & \begin{tabular}{|c|} 
EMPLEO \\
DE \\
VIOLENCIA \\
EN FUGA \\
\end{tabular} & $\begin{array}{l}\text { ¿ES UTIL Y } \\
\text { NECESARIO } \\
\text { RETORNAR AL } \\
\text { MEDIO CERRADO? } \\
\end{array}$ & $\begin{array}{c}\text { PROGRAMA } \\
\text { ACTUAL }\end{array}$ & $\begin{array}{l}\text { PADRES } \\
\text { O } \\
\text { TUTOR }\end{array}$ & $\begin{array}{c}\text { FACTOR DE } \\
\text { RIESGO }\end{array}$ & ¿DEBE VOLVER AL MEDIO CERRADO? \\
\hline 1 & Asesinato & Vida & Sí & No & $\begin{array}{l}\text { Sí, conducta reviste } \\
\text { gravedad y afectó vida o } \\
\text { integridad. }\end{array}$ & 4to & sí & $\begin{array}{c}\text { Consumo de } \\
\text { drogas }\end{array}$ & $\begin{array}{l}\text { sí, deberá volver al programa } 4 \text { to por la } \\
\text { naturaleza del delito cometido. }\end{array}$ \\
\hline 2 & Secuestro & $\begin{array}{l}\text { Libertad } \\
\text { ambulatoria }\end{array}$ & Sí & No & $\begin{array}{c}\text { Sí, conducta reviste } \\
\text { gravedad y afectó vida o } \\
\text { integridad. }\end{array}$ & 4to & sí & Pandillaje & $\begin{array}{l}\text { Sí, deberá volver al programa } 4 \text { to por la } \\
\text { naturaleza del delito cometido. }\end{array}$ \\
\hline 3 & $\begin{array}{l}\text { Violanción } \\
\text { sexual }\end{array}$ & Libertad sexual & Sí & No & $\begin{array}{c}\text { Sí, conducta reviste } \\
\text { gravedad y afectó vida o } \\
\text { integridad. }\end{array}$ & 4 to & sí & $\begin{array}{c}\text { Hogar } \\
\text { disfuncional }\end{array}$ & $\begin{array}{l}\text { Sí, deberá volver al programa } 4 \text { to por la } \\
\text { naturaleza del delito cometido. }\end{array}$ \\
\hline 4 & Robo & Patrimonio & Sí & No & $\begin{array}{l}\text { Solo si la conducta } \\
\text { reviste gravedad y se } \\
\text { afecta de manera } \\
\text { importante a la vida o } \\
\text { integridad fisica o } \\
\text { psicológica. }\end{array}$ & 4to & sí & $\begin{array}{c}\text { Anomia } \\
\text { (innovador) }\end{array}$ & $\begin{array}{l}\text { Dependerá de la gravedad que revista la } \\
\text { infracción cometida, motivo del encierro. E1 } \\
\text { Patrimonio es acumulable y posee una } \\
\text { naturaleza restaurativa; en cambio, otros bienes } \\
\text { jurídicos fundamentales no poseen dicha } \\
\text { característica }\end{array}$ \\
\hline 5 & Hurto & Patrimonio & Si & No & $\begin{array}{l}\text { No, se afectó al } \\
\text { patrimonio y ello es } \\
\text { restaurativo }\end{array}$ & 4to & sí & $\left|\begin{array}{c}\text { Anomia } \\
\text { (innovador) }\end{array}\right|$ & $\begin{array}{l}\text { No. Ya que el delito que cometió no reviste } \\
\text { gravedad y no afectó la vida o la integridad } \\
\text { física o psicológica. Se debe emplear la } \\
\text { nueva Remisión para alejar al adolescente } \\
\text { del Sistema Penal }\end{array}$ \\
\hline
\end{tabular}

Elaboración Propia. Tabla que ejemplifica los casos en que se podrá emplear el nuevo supuesto de remisión.

a) Perfil del adolescente infractor: La infracción motivo de su encierro no reviste gravedad y no colocó en grave peligro la vida o integridad física o psicológica de la víctima.

b) Naturaleza de la fuga: La fuga debe ser sin violencia, sin uso de armas o amenazas. El ideal está determinado por una oportunidad, en la que el instinto sea activado y se busque la libertad. No se puede cometer un nuevo delito/infracción, ni recibir ayuda ilegal de algún miembro del recinto.

c) Padres o Tutor ${ }^{33}$ : El menor que fuga necesita de sus padres o tutor, toda vez que requiere de alguien que pueda asegurar protección, amor y cuidado (McNeill, Farrall, Maruna, 2012).

\footnotetext{
${ }^{33}$ Shadd Maruna en su estudio concluyó que es posible que la persona no vuelva a reincidir cuando se aleja totalmente del entorno -acumulación de factores de riesgo- que fue necesario para la ejecución de su conducta prohibida. Coloca el ejemplo de un ex interno para explicar, el cambio en la persona gracias a que se mudó del lugar de donde residía: Lo hizo solo, sin padres ni tutores; en ese sentido Maruna, establece que es posible dejar de cometer infracciones cuando se eliminan los factores de riesgo (estrictamente lugar de residencia), señala además en el ejemplo, que la etiqueta se rompe ya que no es muy fácil reconocer a un ex interno en una nueva ciudad donde nadie conoce al ex infractor.
} 


\section{5.- Límites racionales de la propuesta}

Toda conducta relevante para el derecho penal está investida dentro de los límites que determinan su naturaleza y utilidad. Por ello, es menester determinar cuál es el ámbito de acción de la nueva Remisión, ello evita la generación de excesos o malos usos; además ampliará sus beneficios, siempre y cuando, se mantenga una dirección alineada a reducir los índices de criminalidad:

Pero no me cabe duda de que, en tanto se trate de los límites del injusto penal, se deben elaborar criterios político-criminales para la interpretación en el marco de las decisiones legislativas valorativas. Así, por ejemplo, el problema de la legitimación y del ámbito de aplicación del principio de prevalencia del Derecho (p. 65 -de la segunda edición alemana-), que cada día más se presenta en el primer plano de la moderna discusión sobre la legítima defensa, es un problema de la extensión de la protección a la vida y a la salud. Se trata de precisar dónde termina la legítima defensa y comienza la, mucha de las veces incluso grave, criminalidad.

(Roxin, 2000, p.112).

En ese sentido dividiremos los límites en dos grandes grupos, el primero referido a la naturaleza del bien jurídico protegido que fue dañado, y el segundo, definido por la conducta que el adolescente realiza con el propósito de obtener su libertad; es decir, externalización de su instinto de búsqueda de la libertad. Por tanto:

\section{a) Gravedad de la infracción cometida}

El Legislador no establece de manera taxativa que se entiende por gravedad o infracción gravosa. En ese sentido, es necesario utilizar el método de interpretación sistemática y teleológica para determinar la connotación del precepto penal "Presupuestos de internación" (art. 162 inc.1 del D.L. núm. 1348) con el concepto de "gravedad".

Ello permite colegir que la infracción que reviste gravedad será la que merece el internamiento (de ultima ratio) del menor en un medio cerrado. Por tanto, la conducta que vulnera un riesgo prohibido debe ser dolosa y el tipo penal debe establecer para aquella contravención una pena no menor de 6 años, siempre que haya puesto deliberadamente en grave riesgo la vida o la integridad física o psicológica de las personas.

Artículo 162. - Presupuestos de la internación

162.1 La internación es una medida socioeducativa privativa de libertad de carácter excepcional y se aplica como último recurso, siempre que se cumpla cualquiera de los siguientes presupuestos:

1. Cuando se trate de hechos tipificados como delitos dolosos y sean sancionados en el Código Penal o Leyes especiales, con pena privativa de libertad no menor de seis (06) años, siempre que 
se haya puesto deliberadamente en grave riesgo la vida o la integridad física o psicológica de las personas;

(Decreto Legislativo $\mathrm{N}^{\circ} 1348,2017$ ).

En consecuencia, son dos los fundamentos que permiten definir aquello que es considerado como gravoso, el primero es el quantum de la pena y el segundo es que se haya colocado en grave riesgo la vida o la integridad -física o psicológica- de la víctima.

Me explico: un muchacho joven ingresa al reclusorio porque robó una miscelánea con una navaja. Se queda unos tres o cuatro años dentro de una prisión que, formal y nominalmente, tiene una oferta educativa, laboral y psicológica que lo "re-educará". En la práctica no lo hace y el joven se vuelve un sirviente de delincuentes peligrosos, que lo instruirán -y muy bien- en las malas artes y que, además, lo involucrarán en la droga. Al término de su estancia saldrá a la calle sin dinero, sin educación (no tiene oficio ni beneficio) con un estigma social -es un ex presidiario-, con un vicio acendrado y con un rencor inmenso. Ésta en peores condiciones que antes de entrar y tiene como referentes lo malo que aprendió en la cárcel. ¿Qué le queda? Lleno de anti-valores recurrirá al crimen como única vía, de fatalismo inconsciente en contra de... ¿quién? ¿Del funcionario poderoso con escoltas? No. En contra de un ciudadano decente que pagó sus impuestos para mantener un sistema de seguridad y uno de reinserción social efectivos que no resultaron, y ahora él o su familia recibirán ese golpe ciego, brutal e inmerecido del rencor, la violencia y la sinrazón. (...) Con una pena mayor -unos doce años- el joven tendrá una perspectiva diferente y se hará más violento, más cruel y más vicioso. Como tiene menos que perder, se vuelve más audaz y puede ascender en la escala estratificada del mal: será reclutado para delitos mayores por bandas mejor organizadas y que lo inducirán, al salir, a los delitos más ominosos y alarmantes, con la complicidad y la tutela policial, en contra, ;claro!, de una sociedad que sigue pensando que lo malo o injusto o ineficiente que ocurra en las cárceles no es de su incumbencia, pero sí lo es.

(Maldonado Manzanilla, 2010, p.82).

En la presente Tesis se asume que encerrar a un menor no violento, en un ambiente muy riesgoso, cruel y violento (donde además estará desprotegido), lo expone a un contacto diferencial donde es muy probable que absorba conocimientos y experiencias criminales. Por ello, será posible aplicar la nueva remisión, cuando un menor que no cometió una infracción grave fugue sin violencia de un centro de internamiento en medio cerrado.

Es necesario comentar que, en un internamiento de medio cerrado, se construye un contexto ideal para que las personas adictas sean transformadas en instrumentos de autores mediatos:

En las prisiones hay un intenso mercado de drogas, y eso permite a los responsables recibir cantidades significativas de dinero a cambio de permitir un tráfico de estupefacientes que le hace posible a cualquier preso - con más facilidad y a precios menores que en la calle- drogarse, supuestamente para evadirse. La droga se vuelve así la gran industria penitenciaria, pues la mayoría de los internos son o se vuelven adictos cautivos y ello permite -y de muchos modos auspicia- todo tipo de delitos al exterior. La necesidad de consumo los obliga a organizar a familiares y amigos para delinquir y surtirlo.

(Maldonado Manzanilla, 2010, pp.79-80). 
Las personas adictas dejaron de ser un fin y se convierten en un medio. El adicto es también un instrumento, utilizado por quienes sí mantienen propósitos de daño y violencia. "Debemos reflexionar que ya soporta, o soportará, toda la penalidad de su error; que ella arruine su vida por una conducta equivocada no es razón para que nosotros deseemos extremar más todavía su ruina: en lugar de desear su castigo, debemos más bien tratar de aliviárselo mostrándole cómo puede evitar o curar los males que su conducta le acarrea" (Stuart Mill, 2013, p.185). Sin descuidar la atención a la víctima y a la sociedad.

\section{b) Ausencia de violencia}

Una vía de escape justificada bajo el instinto de búsqueda de libertad no puede admitir ninguna cuota de violencia. Si representa un riesgo u ocasiona un daño, desvirtúa su propia utilidad.

En este contexto, el nuevo supuesto de remisión aprovecha los errores de la administración judicial, una mala defensa, exceso de castigo, ambiente nocivo, etc., y evita el efecto escuela que brinda un plan de "resocialización". Si no es necesario ni útil mantener a una persona en un centro de internamiento, entonces no se debe de utilizar la medida efectiva como una medida educativa, pues el efecto a todas luces es contraproducente.

Por tanto, el objetivo es alejar al adolescente infractor -no violento que escapa aprovechando la ineficiencia de control del sistema y que no cometió una infracción grave- del sistema penal y a toda evitar el contacto diferencial: especialización. La lucha contra la violencia no puede ni debe ser combatida con más violencia, sus soluciones, del mismo modo, tampoco mantienen la misma dirección. En consecuencia, un joven que obedece a su instinto, sin utilizar violencia, es un joven que merece la libertad.

Cabe señalar que la restauración/recuperación, en una conducta que vulnere la libre disposición de patrimonio, es posible. Después de un esfuerzo, trabajo continuo, disciplina, el objeto material afectado puede ser restablecido. La riqueza es una respuesta directa a la proporción de trabajo continuo (Priest, 2006, p.245).

En consecuencia, si la fuga -orientada por el instinto de búsqueda de la libertad- es logrado dañando o violentando a otras personas, no será posible utilizar este supuesto de la nueva remisión. La oportunidad de salir de un internamiento debe estar libre de cualquier acto que dañe bienes jurídicos protegidos descritos en el anterior acápite. 
Pero también las penas practicadas actualmente en Europa de manera general seguirán siendo atenuadas. Esto resulta paradójico solamente a primera vista, porque corresponde al raciocinio del profano reaccionar con penas más fuertes ante la creciente criminalidad. Pero si se ve esto con más exactitud, puede ser fácilmente explicado, pues la privación de libertad que ha dominado en los países europeos desde la eliminación de las penas corporales, ya ha dejado su apogeo detrás de sí y seguirá retrocediendo cada vez más. Ello se debe a dos razones.

Por un lado, es cada vez menos posible reaccionar a la mayoría de delitos con penas privativas de libertad en la medida en que las disposiciones penales aumentan y crecen con ello los hechos punibles. Los establecimientos penales no son ni siquiera cercanamente suficientes para ello, así como tampoco lo son los recursos financieros necesarios para una ejecución penal humanitaria. Por otro lado, tampoco es deseable por política criminal la imposición de penas privativas de libertad de manera masiva, pues según el saber criminológico en los delitos pequeños y medianos, que constituyen la mayor cantidad de los delitos, es imposible una (re-) socialización por la vía de la privación de la libertad. No se puede aprender bien cómo llevar una libertad una vida fiel a la ley mediante la privación de la libertad: la pérdida del puesto de trabajo y la separación de la familia, vinculadas con la pena privativa de libertad, tienen un efecto desocializador adicional. (Roxin, 1998).

Los países que resolvieron su problema criminal demuestran el camino progresivo que describe en las líneas anteriores Roxin; es en tanto el mejor referente y guía que permitirán identificar los factores estructurales que ocasionarán la modificación en el castigo y la mejoría del sistema penal.

El nuevo supuesto se introduciría así: Se aplicará la remisión cuando el adolescente haya fugado sin violencia del medio cerrado y cuando el hecho atribuido se trate de una infracción a la ley penal que no revista gravedad. Y se positivizaría de la siguiente manera en el artículo 130, inciso 3: Cuando el adolescente se haya evadido sin violencia del medio cerrado y cuando el hecho atribuido, motivo de su internamiento, se trate de una infracción a la ley penal que no revista gravedad.

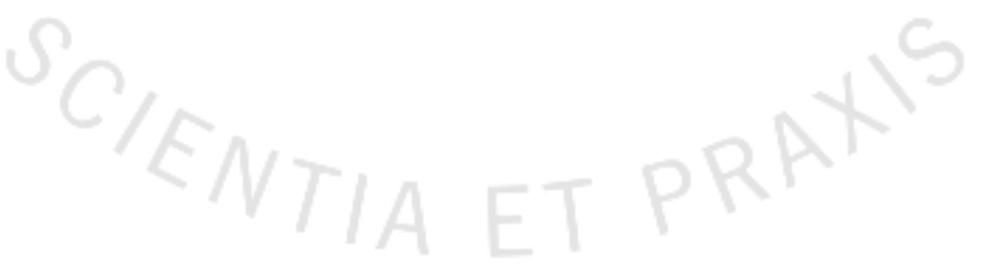




\section{CONCLUSIONES}

1. La criminalidad es un fenómeno social que no será posible erradicar.

2. El factor estructural, junto con los demás factores de riesgo acarrean la actividad delictiva. La manera eficiente de mitigar los efectos nocivos del crimen se logra reduciendo los niveles de vulnerabilidad de las personas; se deben de crear oportunidades y beneficios en lugar de castigos exacerbados.

3. El índice de victimización es inversamente proporcional al nivel de percepción que tiene la población con respecto a la comisión de conductas vulneradoras de bienes jurídicos. La percepción equivocada de la criminalidad genera la pérdida de solidaridad, merma los lazos sociales y disminuye la calidad de vida de la población.

4. Las enfermedades adictivas deben ser tratadas en centros especializados de rehabilitación médica, no en centros juveniles de medio cerrado.

5. El concepto de peligrosidad es creado por el grupo de poder de cada sociedad, responde a conceptos irracionales y asimétricos. Cada sociedad define un enemigo. Para el caso peruano el enemigo es el grupo social y económicamente desfavorecido.

6. El encierro genera estigmatización. Se margina al pobre que roba, pero no al rico, él hace negocios.

7. El contexto en que las personas se desempeñan modula su comportamiento; los conceptos de bondad y maldad varían según el medio en el que se encuentren.

8. Es una práctica aceptada en el encierro, el tratamiento basado en la violencia mediante malos tratos, aislamiento disciplinario por un tiempo promedio de 3 meses. Este incluye el empleo de una severa violencia física y psicológica, no permite visitas, restringe ciertas comidas y prohíbe la salida a los espacios comunes.

9. El comportamiento desviado es producto del desarrollo de maduración de la persona, se inicia alrededor de los 14 años, se incrementa a los 21 y a partir de esa edad el comportamiento delictivo disminuye progresivamente.

10. El instinto de búsqueda de libertad es inherente a la condición humana. 
11. La conducta que propicia la evasión no violenta de un centro de rehabilitación forma parte de la libertad jurídicamente garantizada. Evadirse del encierro -aunque el internamiento fuera legítimo- no constituye delito (para los mayores) ni infracción penal (para los adolescentes); en tanto la fuga no fuera violenta.

12. Negar oportunidades a las personas que trasgreden el ordenamiento penal reduce de manera considerable la posibilidad del crecimiento social, económico y moral.

13. La dignidad no desaparece ni es disminuida con la imposición de una medida socioeducativa de internamiento en medio cerrado. El encierro de adolescentes infractores supone una rehabilitación en un medio beneficioso, con medidas diversas que apliquen el internamiento en medio cerrado solo como última opción y por el menor tiempo posible, sin tratos inhumanos (como el aislamiento); con la asistencia especializada adecuada que asegure su recuperación y brinde una verdadera reinserción social.

14. La medida socioeducativa de internamiento solo debe aplicarse para aquellos adolescentes que cometieron una infracción grave. Se debe entender por grave toda conducta dolosa que merezca pena privativa de libertad no menor de 6 años, siempre que se haya puesto deliberadamente en grave riesgo la vida o la integridad física o psicológica de las personas.

15. El excesivo tiempo de encierro genera el aprendizaje de conductas criminales por intensidad y durabilidad en la convivencia.

16. El continuo incremento del populismo penal genera exacerbados niveles de hacinamiento. Ocho de los nueve Centros Juveniles de Diagnóstico y Rehabilitación del Perú se encuentran con márgenes de hacinamiento, superiores al $40 \%$.

17. Los Informes Técnicos Multidisciplinarios no constituyen un rol primordial en la determinación de la medida socioeducativa, más bien, son utilizados como justificación en la aplicación de la medida de internamiento en medio cerrado.

18. Existe una desproporción entre el número de menores y el número de los equipos de tratamiento. Muchos adolescentes no son contactados ni una sola vez en el día por los psicólogos del centro.

19. El principal objetivo (resocializador, rehabilitador y de reinserción) de los Centros Juveniles de Diagnóstico y Rehabilitación en el Perú ha mutado, de facto y de iure, por uno de contención. 
20. En internamiento, están afectados los derechos esenciales que la auto tutela (representada por la evasión no violenta) pretende poner a salvo o intenta cortar la cadena de afectaciones en curso. Evadirse de un medio cerrado, sin mediar violencia en la fuga, es entendido como un acto de autoprotección en un contexto de estado de necesidad.

21. La detención de un adolescente infractor que evade de un centro de internamiento sin violencia deviene en un acto inconstitucional y nulo.

22. No es razonable que la Administración de los Centros Juveniles, reaccione ante la fuga no violenta, castigando la conducta de autoprotección que la evasión pacífica implica.

23. La Justicia Restaurativa se erige sobre la Justicia Retributiva. La Justicia Restaurativa evita el etiquetamiento, el aprendizaje de conductas vulneradoras, el fenómeno "puerta giratoria" y mitiga el avance de la criminalidad. La Justicia Restaurativa procura la reparación del daño o recuperación del objeto material afectado; en ese sentido, dicha justicia debe ser aplicada para todos los supuestos donde el bien jurídico dañado pueda ser reparado por el adolescente infractor.

24. Establecer puntos de inflexión en las personas que quieran desistir de la actividad criminal, ocasiona la implementación de medidas eficientes que solo generan beneficios al individuo y a la sociedad.

25. La Remisión se presenta como una alternativa de resocialización sin que medie ningún tipo de violencia de parte del Sistema Penal. La Remisión representa una oportunidad de resocialización en sociedad, evita la imposición del internamiento en medio cerrado para aquellos jóvenes que cometieron ciertas infracciones de mínima lesividad. En caso de evasión no violenta se debe posibilitar la aplicación de la Remisión.

26. Están institucionalizados en el medio cerrado, adolescentes que perpetraron infracciones de menor connotación como hurtos y robos, sin mayor violencia ni tenencia de armas. No es necesario ni útil encerrar a adolescentes que afectaron el patrimonio sin causar mayores daños a bienes jurídicos fundamentales.

27. La víctima debe ser reparada, conocer la verdad y ser reintegrada a la sociedad. La interacción entre la víctima y el adolescente infractor genera un círculo virtuoso de renovación automática. 


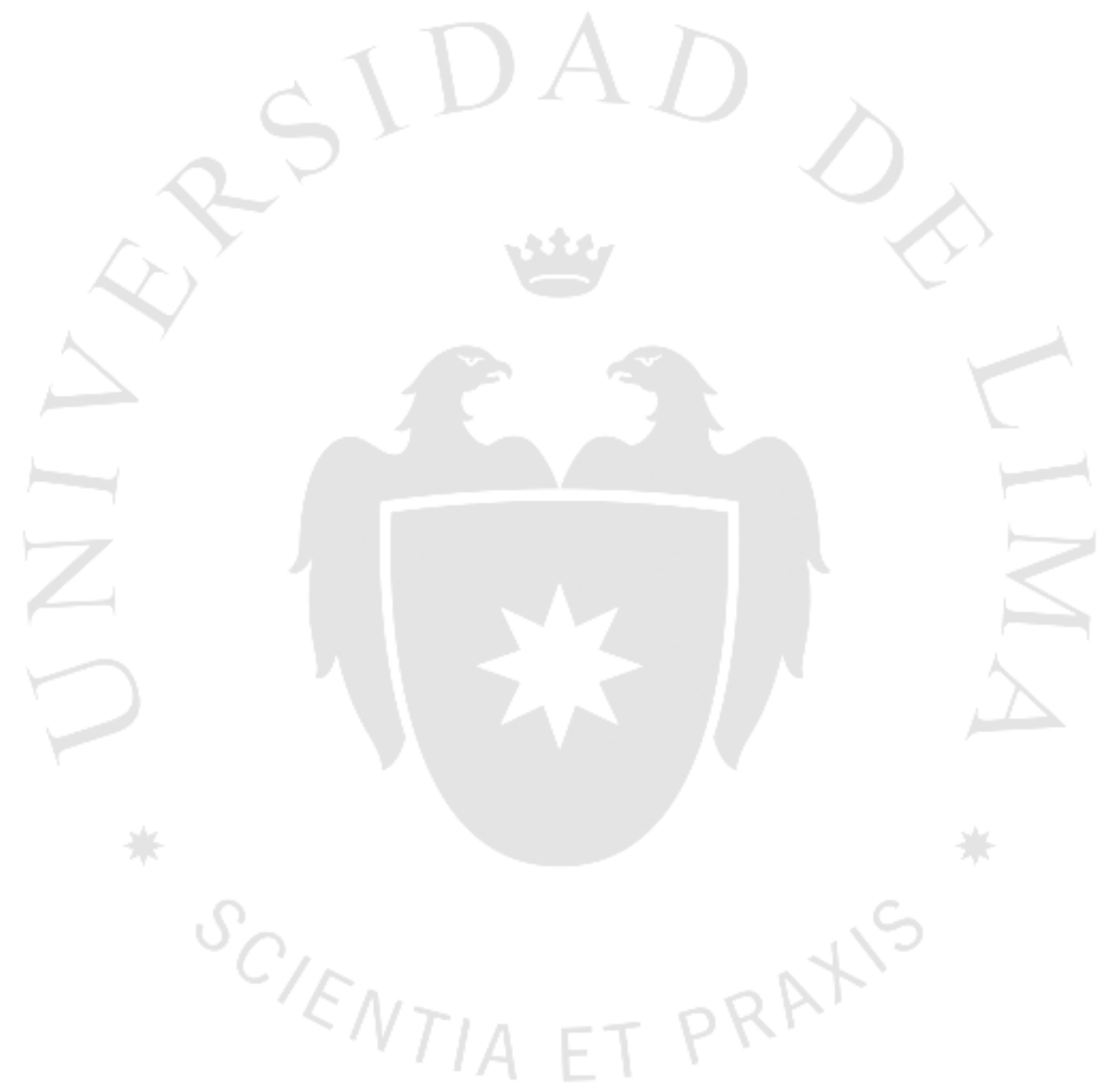




\section{RECOMENDACIONES}

1.- Es necesario crear campañas de sensibilización dirigida a Jueces y Fiscales con el propósito de hacer más efectivo el uso de los Medios Abiertos. Estos contribuyen a una mejor resocialización, lo menores aprenden un oficio y no están expuestos (en duración e intensidad) al contacto con otros menores con perfiles infractores más graves.

2.- Se requiere revisar el perfil profesional de los educadores sociales, con requisitos específicos, dada la trascendencia de su labor en favor de los infractores en concreto y de la sociedad en general. La especialización y la dedicación se alientan con remuneraciones adecuadas que en este momento no brinda el sistema de atención a los infractores. La baja remuneración de 1,800.00 soles en la planilla general de los Centros Juveniles de Diagnóstico y Rehabilitación genera, en gran medida, corrupción denominada en el medio cerrado como "Servicio de protección al muchacho". Viendo vulnerado el fin prestacional del Estado (a través del tratamiento resocializador), los educadores justifican la desviación del interés social, en uno personal.

3.- La implementación progresiva de la Justicia Restaurativa genera una campaña indirecta de sensibilización respecto a los menores infractores, ya que permite a la Víctima conocer las causas de su conducta prohibida (y en ciertos casos, recuperar el bien jurídico dañado). De esa manera, utilizar más la remisión hace posible que se establezca una política criminal eficiente, dirigida a diversos estratos de la sociedad. 


\section{REFERENCIAS}

Aguilar, P. (2012). Licencia para matar: El regreso del ojo por ojo. Ideele Revista $N^{\circ} 215$.

Recuperado de http://revistaideele.com/ideele/content/licencia-para-matar-el-regreso-delojo-por-ojo

Araujo, C. (2003). Bentham: el utilitarismo y la filosofía política moderna. (276). En, BORON, Atilio A. (Compilador) La Filosofía Política Moderna. De Hobbes a Marx. Argentina: CLASCSO. Buenos Aires. Págs. 269-288.

Aristóteles. (2005). Naturaleza de la ciencia; diferencia entre la ciencia y la experiencia. Libro primero. A. 980a-993a. Página web de Patricio de Azcárate. Proyecto Filosofía en español. Obras de Aristóteles Madrid 1875, tomo 10, páginas 51-54. Recuperado de http://www.filosofia.org/cla/ari/azc10051.htm

Base de datos de los expedientes recopilados por la defensoría del pueblo en cinco distritos

judiciales.

Recuperado

de http://www2.congreso.gob.pe/sicr/cendocbib/con3_uibd.nsf/7FB8E8BD618BB73A05257 90400782FEF/\$FILE/ID-153_Informe_Defensor\%C3\%ADa_del_Pueblo.pdf

Baratta, A. (2004). Criminología, Crítica y crítica del Derecho penal. Introducción a la sociología jurídico-penal. Argentina: Siglo veintiuno editores. Pág. 198.

Barkan, S. (2012). Criminology. A sociological Understanding. University of Maine. PEARSON. Fifth Edition.

Beccaria, C. (2012). De los delitos y las penas. Sexta reimpresión de la tercera edición. Colombia: Editorial Themis S.A. Pág. 51.

Becker, G. (2000). Crimen y Castigo: Un enfoque económico. En, Derecho y Economía: una revisión de la literatura. Selección de obras de Economía Contemporánea. México: Fondo de Cultura Económica. Págs. 383-436. Pág. 411.

Bentham, J. (1965). Escritos Económicos. México: Fondo de Cultura Económica. Pág. 180

Bentham, J. (1990). Falacias Políticas. Centro de Estudios Constitucionales. Madrid:

MARASAN S.A. Pág. 157.

Brage Cedán, S. (2013). Cuadernos de Criminología. España: Bosch editor. Pág.

$117,118$. 
Calise, S. (2010). Dignidad y Clonación Humana en el Sistema Jurídico Argentino.

Iberofórum. Revista de Ciencias Sociales de la Universidad Iberoamericana. Año V, No 10. Julio - Diciembre de 2010. Pp. 125-160. ISSN: 2007-0675. Pág. 133-134.

Carranza, E. (Coordinador). (2001). Justicia Penal y Sobrepoblación Penitenciaria, Respuestas Posibles. Siglo veintiuno editores, México. Pág. 52.

Comisión Interamericana De Derechos Humanos. (2015). Situación de Derechos Humanos en

Honduras. OEA/Ser.L/V/II. Doc. 42/15. 31. Recuperado de http://www.oas.org/es/cidh/informes/pdfs/Honduras-es-2015.pdf

Consejo Nacional De Política Criminal. (2014). Plan Nacional De Prevención Y Tratamiento Del Adolescente En Conflicto Con La Ley Penal 2013-2018. Lima: Grupo Raso E.I.R.L. Pág. 9.

Convención Americana sobre Derechos Humanos (Pacto de San José). Recuperado de https://www.oas.org/dil/esp/tratados_B32_Convencion_Americana_sobre_Derechos_H $\underline{\text { umanos.htm }}$

Convención sobre los derechos del niño. (1989). Recuperado de

http://www.unicef.org/panama/spanish/convencion(3).pdf

Couso, J. (2012). La especialidad del Derecho Penal de Adolescentes. Fundamentos empíricos y normativos, y consecuencias para una aplicación diferenciada del Derecho Penal Sustantivo. Revista de Derecho de la Pontificia Universidad Católica de Valparaíso XXXVIII (Valparaíso, Chile, 2012, 1er semestre pp. 267-322). Recuperado de http://www.scielo.cl/pdf/rdpucv/n38/a07.pdf

Defensoría del Pueblo. (2011). Informe: Niños, niñas y adolescentes en abandono: aportes para un nuevo modelo de atención. Lima. Pág. 128 y ss. Recuperado de http://www2.congreso.gob.pe/sicr/cendocbib/con3_uibd.nsf/7FB8E8BD618BB73A052 5790400782FEF/\$FILE/ID-153_Informe_Defensor\%C3\%ADa_del_Pueblo.pdf

De Soto, H. En colaboración con Ghersi, E. y Ghibellini, M. (1986). El otro sendero. La revolución informal. Tercera edición. Lima: Editorial el Barranco.

Díez Ripollés, J. (2005). De la sociedad del riesgo a la seguridad ciudadana: Un debate desenfocado. Revista electrónica de ciencia penal y criminología. Artículos PECPC 0701.

El Comercio. (2015). Adopciones 60\% de niños en abandono no están declarados aptos. Publicado 
el Lunes 9 de febrero de 2015. Recuperado de http://elcomercio.pe/sociedad/lima/adopciones-60-ninos-abandono-no-estandeclarados-aptos-noticia-1790292

Fernández Calvo, L. (2006). La sobrepoblación en las cárceles del Perú es del 132\%. El Comercio. Sociedad. Martes 5 de abril de 2006. Fecha de consulta: 31 de agosto de 2016. Recuperado de http://elcomercio.pe/sociedad/peru/sobrepoblacion-carceles-peru-132noticia-1891857

Ferrajoli, L. (1995). Derecho y razón. Teoría del garantismo penal. España: Editorial Trotta. Recuperado de http://www.cubc.mx/biblioteca/libros/29.\%20Derecho\%20Y\%20Razon\%20Teoria\%20Del\%20Garantismo\%20Penal\%20\%20Ferrajoli.pdf

Foucault, M. (1999). Vigilar y Castigar. Nacimiento de la Prisión. México: Siglo Veintiuno Editores. Edición 29. 314 páginas.

Foucault, M. (2015). Un diálogo sobre el poder y otras conversaciones. España: Alianza Editorial. Págs. 35-36

Garland, D. (2005). La cultura del control. Crimen y orden social en la sociedad contemporánea. Traducción de Máximo Sozzo. España: Editorial Gedisa.

Ghersi, E. (s.f). El costo de la legalidad. Lima. Recuperado de: https://www.cepchile.cl/cep/site/artic/20160303/asocfile/20160303184142/rev30_ghers i.pdf

Grondona, M. (1994). Los pensadores de la libertad. De John Locke a Robert Nozick. Séptima edición. Argentina: Editorial Sudamericana. Pág. 72-73.

Hayek, F. (2014). Los fundamentos de la libertad. Novena edición. Traducción de José Vicente Torrente. España: Unión Editorial. Pág. 58-59.

Human Rights Watch. (2015). Brazil: Where Inmates Run the Show. Among Brazil's Overpacked Prisons, Pernambuco Tops the List. Recuperado de https://www.hrw.org/news/2015/10/19/brazil-where-inmates-run-show

Humphreys, K. (2015). The U.S. imprisonment rate has fallen for the fifth straight year. Here's why. The Washington Post. Recuperado de https://www.washingtonpost.com/news/wonk/wp/2014/09/16/the-u-s-imprisonmentrate-has-fallen-for-the-fifth-straight-year-heres-why/ 
Jakobs, G. y Polaino Navarrete, M. (2006). El Derecho penal ante las sociedades modernas. Dos estudios de dogmática penal y política criminal. México DF: Flores Editor y Distribuidor. Pág. 79.

Levitt, S. \& Dubner, S. (2009). Freakonomics, A rogue economist explores the hidden side of everything. New York: HARPER. Págs. 115-147.

Ekunwe, I. y Jones, R. (s.f.) Finish Criminal Policy: From hard time to gentle justice. Marquette University. Social and Cultural Sciences, Department of publications. 6-1-12. Pág. 4, 5.

Lissardy, G. (2015). Canibalismo y decapitaciones: el horror que se vive en las cárceles de Brasil. BBC Mundo, Brasil. Publicado el 23 de noviembre de 2015. Relato del Fiscal brasilero Gilberto Câmara França Júnior. Consulta: 28 de febrero de 2016. Recuperado http://www.bbc.com/mundo/noticias/2015/11/151119_brasil_prisiones_relatos_de_horr or_gl?ocid=socialflow_facebook\#orb-banner

Maldonado Manzanilla, L. (2010). Las paradojas de la libertad: una reflexión personal desde la ergástula. En, Caminos de la libertad (Cuarto concurso de Ensayo) Coordinador: Sergio Sarmiento. México: Fomento Cultural Grupo Salinas. Pág. 81.

Maruna, S. (2001). Making Good. How ex-convicts reform and rebuild their lives. American Psychological Association Washington D.C.

Matza, D. (2014). Delincuencia y Deriva. Cómo y Por qué algunos jóvenes llegan a quebrantar la ley. Traducción de Teresa Arijón. Argentina: Siglo 21 editores. Recuperado de http://www.sigloxxieditores.com.ar/pdfs/matza_delincuencia_y_deriva.pdf

Medina Salas, I. (2016). Crónica de un hacinamiento anunciado. A propósito de la ley de flagrancia: las consecuencias de un régimen penal más duro, rápido e improvisado. Lima: Gaceta Penal \& Procesal Penal. N 82, Gaceta Jurídica. Págs. 291-297.

Merino, B. (2007). La situación de los adolescentes infractores de la ley penal privados de libertad. Supervisión de los centros juveniles 2007. En el centro juvenil "Santa Margarita. Discurso en conferencia de prensa organizada con motivo de la presentación del informe defensorial $N^{\circ} 123$. Recuperado de http://www.defensoria.gob.pe/modules/Downloads/prensa/discursos/2007/discurso17-07-07.pdf 
Merton, R. (2010). Teoría y estructura sociales. Traducción Mario Bunge. México: Fondo de Cultura Económica. Recuperado de https://rfdvcatedra.files.wordpress.com/2013/08/robert-k-merton-teoria-y-estructurasociales-funciones-manifiestas-y-latentes.pdf

Stuart Mill, J. (2013). Sobre la libertad. España: Alianza Editorial. Pág. 156.

Morris, N. (1998). El futuro de las prisiones. Estudios sobre crimen y justicia. Quinta edición en español. (Primera edición en inglés, 1974 by University of Chicago. The future of imprisonment -studies in crime and justice-) México: Siglo veintiuno editores. Pág. 17.

Montesquieu. (1999). El espíritu de las leyes. Grandes Clásicos del Derecho. Volumen 5. Oxford, University Press. México Págs. 328-329.

Muñoz Acebes, C. (2016). El Estado Dejó al Mal Tomar Control. La Crisis Penitenciaria en el Estado Brasilero de Pernambuco. (The State Let Evil Take Over. The Prison Crisis in the Brazilian State of Pernambuco.) Consulta: 28 de febrero de 2016. Recuperado de https://www.hrw.org/node/281914\#page

Muñoz Conde, F. Hassemer, Winfried. (2012). Introducción A La Criminología Y A La Política Criminal. España: Tirant Lo Blach. Pág. 26.

Naciones Unidas Derechos Humanos. (s.f.) Oficina del Alto Comisionado. Reglas mínimas para el tratamiento de los reclusos. Recuperado de http://www.ohchr.org/SP/ProfessionalInterest/Pages/TreatmentOfPrisoners.aspx

OIT. (2000). Informe sobre el trabajo en el mundo 2000. La seguridad de los ingresos y la protección social en un mundo en plena transformación. Oficina Internacional del Trabajo, Ginebra, 2000. Punto 13, pág. 3. Recuperado de http://www.ilo.org/public/spanish/standards/relm/gb/docs/gb279/pdf/esp-7.pdf

Pavarini, M. (2008)._Control y Dominación. Teorías criminológicas burguesas y proyecto hegemónico. Traducción Ignacio Muñagorri. México: Siglo 21 editores. Recuperado de http://www.pensamientopenal.com.ar/system/files/2014/12/doctrina39912.pdf

Pérez Correa, C. (2014). Las mujeres invisibles: Los verdaderos costos de la prisión. Banco Interamericano de Desarrollo. México: Edición PDF.

Perú21. (2014). Trabas para adoptar: Cerca de 15 mil niños peruanos esperan por un hogar. 
Publicado el sábado 20 de diciembre del 2014. Recuperado de http://peru21.pe/actualidad/solo-10-ninos-son-adoptados-al-mes-mientras-15-milcontinuan-esperando-2207115

Pietro Sanchís, L. (2007). La Filosofía Penal de la Ilustración. Lima: Palestra Editores. Págs. 44 y 45.

Poder Judicial. (2013). Recapturan a adolescente interna que había fugado del centro juvenil Santa Margarita. Oficina de imagen y prensa de la Corte Suprema de Justicia. Lima, 22 de diciembre 1 de 2013 Recuperado de https://www.pj.gob.pe/wps/wcm/connect/cortesuprema/s_cortes_suprema_home/as_i nicio/as_enlaces_destacados/as_imagen_prensa/as_notas_noticias/2013/cs_n_stamarg $\underline{\operatorname{arita0} 01 \_23122013}$

Priest, G. (2006). Reduciendo la pobreza global: teoría, práctica y reforma. En, SELA 2005. (Seminario en Latinoamérica de Teoría Constitucional y Política). Derecho y Pobreza. Argentina: Editores del Puerto S.R.L. Págs. 225-245.

Shavell, S. (2000). El Derecho Penal y el uso óptimo de sanciones no monetarias como medida de disuasión. En, Derecho y Economía: una revisión de la literatura. Selección de obras de Economía Contemporánea. México: Fondo de Cultura Económica. Págs. 383-436. Pág. 441.

Sotomayor Acosta, J. (1996). Inimputabilidad y Sistema Penal. Colombia: Editorial

Temis S.A.

Taylor I., Walton P. y Young J. (1997). La nueva criminología. Contribución a una teoría social de la conducta desviada. Argentina: Amorrortu editores. Recuperado de https://criminologiacabana.files.wordpress.com/2015/08/ian-taylor-paul-walton-jockyoung-la-nueva-criminologia-contribucic3b3n-a-una-teorc3ada-social-de-laconducta-desviada.pdf

The National Academies Press. (2014). The Growth of Incarceration in the United States:

Exploring Causes and Consequences. Washintong, D.C.: Jeremy Travis, Bruce Western, and Steve Redburn, Editors. Pág. 36.

Reglas de las Naciones Unidas para la protección de los menores privados de libertad (Reglas de 
http://www2.congreso.gob.pe/sicr/cendocbib/con4_uibd.nsf/34A92F9617F7078D052 57E6F00765C0C/\$FILE/resumen-reglas-de-la-habana.pdf

Reglas Mínimas de las Naciones Unidas para la administración de justicia de menores (Reglas de Beijing). (1985). 29 de noviembre de 1985. Pág. 6. Recuperado de https://www.pj.gob.pe/wps/wcm/connect/ac3ad98045d5e8c8bcfafcd6226b5e16/Regla $\underline{\text { s+de+Beijing.pdf?MOD=AJPERES }}$

Roxin, C. (1998). Dogmática penal y política criminal. Traducción de Manuel Abanto

Vásquez. Perú. IDEMSA. Pág. 440.

Roxin, C. Conversaciones con Claux Roxin. (2014). En entrevista por Dr. Raúl Pariona Arana.

Alerta Informativa. Video de 3 de febrero 2014. [Archivo de video] Recuperado https://www.youtube.com/watch?v=7JZFEmrUdhc

Roxin, C. (2000). Política criminal y sistema de derecho penal. Traducción e introducción de Francisco Muñoz Conde. Segunda edición. Argentina: Editorial Hammurabi SRL. Pág. 49.

U.S. Department Of Justice. (2014). Correctional Populations on the United States, 2014.

December 2015, NCJ 249513. Recuperado de http://www.bjs.gov/content/pub/pdf/cpus14.pdf

Urteaga Cabrera, L. (2014). Los Hijos del Orden. Clásicos Peruanos Contemporáneos. Lima:

Casa Tomada.

Zaffaroni, E. (2005). ¿Qué hacer con la pena? Las alternativas a la prisión. Revista

Peruana de Jurisprudencia, Compendio especializado. Volumen $N^{\circ}$ 42, julio 2005.

Págs. 7-23.

Zaffaroni, E. (2012). La emergencia del miedo. Argentina: Editora Ar S.A. Pág. 26.

Zaffaroni, E. (1993). La experiencia del penitenciarismo contemporáneo. Revista en línea Carlos

Parma, Derecho Penal - y Criminología. Recuperado de: http://www.carlosparma.com.ar/la-experiencia-del-penitenciarismocontemporaneo/

Zaffaroni, E. (1997). La filosofía del sistema penitenciario en el mundo contemporáneo. Perú: Themis, Revista de Derecho. Volumen No 35, junio 1997. Págs. 179-191. 


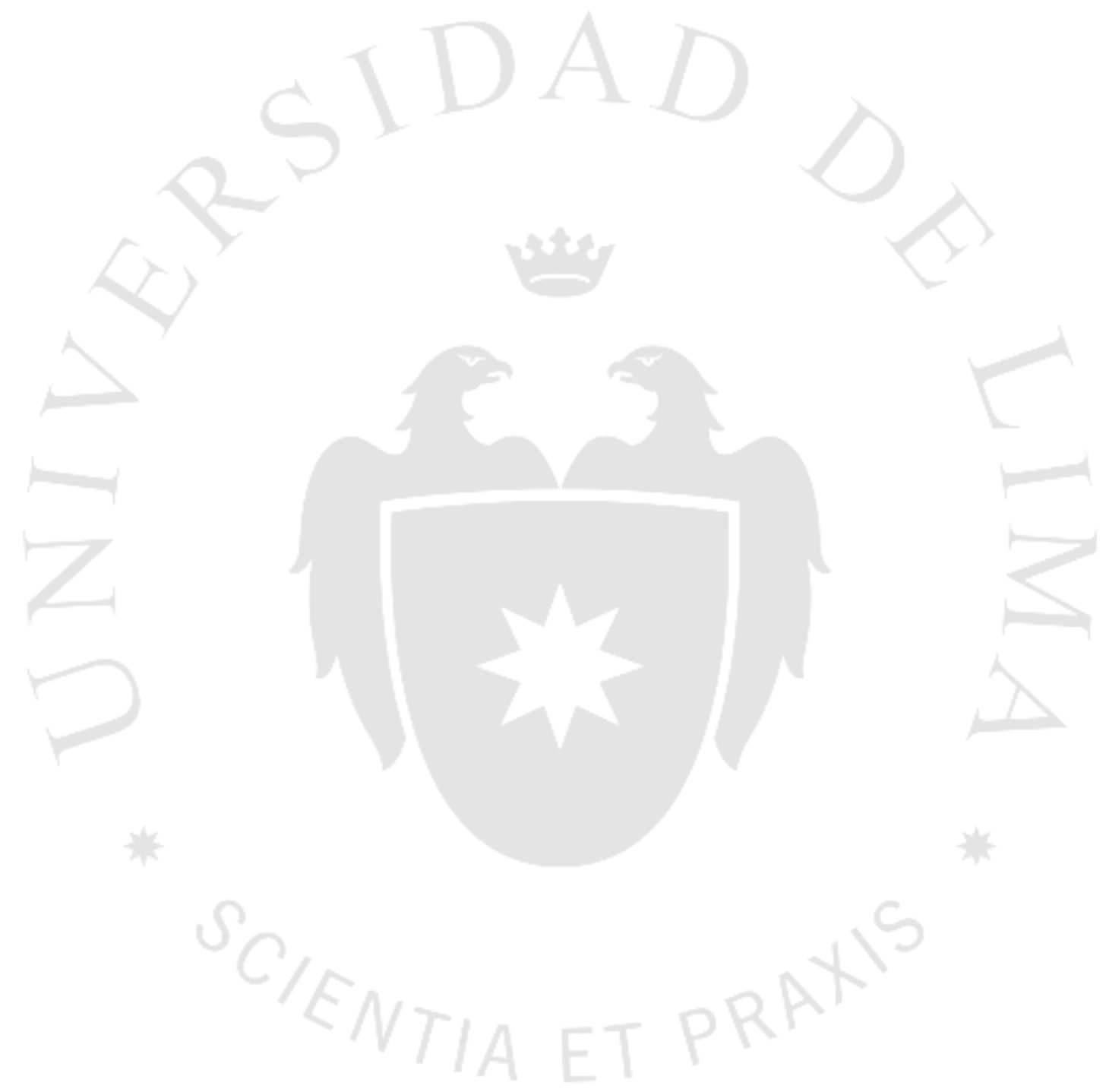




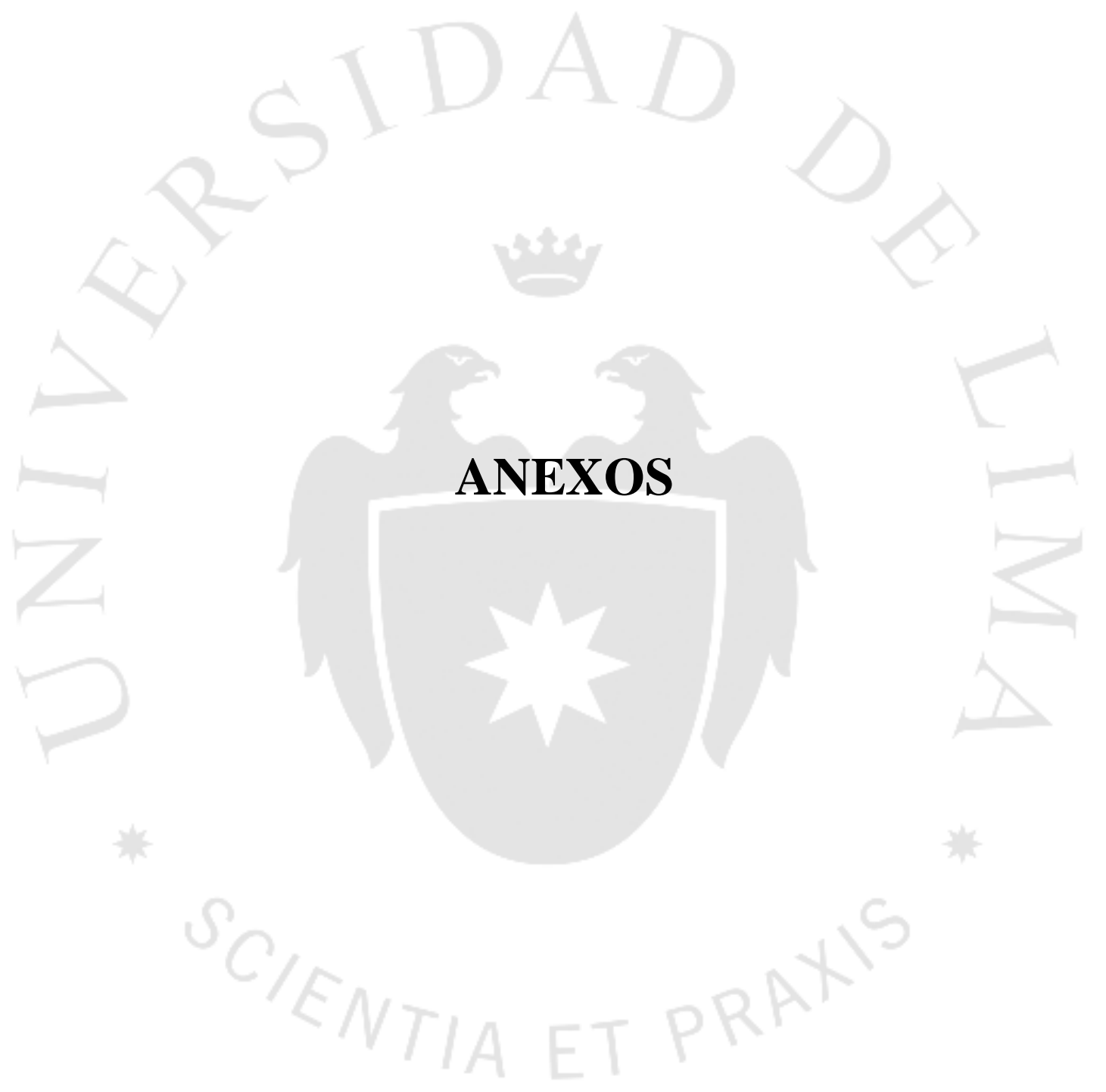

